\title{
CIDADES SAUDÁVEIS NO BRASIL E OS PROCESSOS PARTICIPATIVOS: OS CASOS DE JUNDIAÍ E MACEIÓ
}

\section{ROSILDA MENDES}

Tese de doutorado apresentada ao Departamento de Prática de Saúde Pública da Faculdade de Saúde Pública da Universidade de São Paulo para obtenção do Grau de Doutor Área de concentração: Serviços de Saúde Pública Orientadora : PROF $^{\mathrm{a}} \mathrm{DR}^{\mathrm{a}}$ MARCIA FARIA WESTPHAL

\author{
SÃO PAULO
}


Dedico este trabalho aos meus pais, Luiz e Nair, para quem a escola na vida foi o trabalho, e que souberam incentivar e dar valor à minha formação. 


\section{AGRADECIMENTOS}

Aos grupos sociais das cidades de Jundiaí e Maceió, pela acolhida e disposição em relatar os caminhos percorridos na luta por melhores condições de vida nas cidades.

Aos gestores e membros das equipes técnicas dos projetos Cidades Saudáveis, pela disponibilidade em auxiliar no levantamento de dados.

À professora Marcia Faria Westphal, pela amizade e dedicada orientação.

Aos professores, Luciano Prates Junqueira, Helena Ribeiro, Eurivaldo Sampaio de Almeida, Eugênio Vilaça Mendes e Antonio Ivo de Carvalho pelas valiosas contribuições nas fases de qualificação e de pré-banca.

Ao professores, Fernando Lefèvre da FSP/USP, e à professora Nina Wallerstein, da New Mexico University, pela colaboração nas discussões metodológicas.

À Université Laval e ao Réseau Québécois de Villes et Villages en Santé, em Québec , Canadá, em especial, ao professor Michel O'Neill, pela oportunidade de estágio e pela orientação.

À Maria Teresa Cerqueira, da Organização Pan-Americana de Saúde Washington (DC) pela atenção e por disponibilizar os documentos.

Ao Conselho Nacional de Desenvolvimento Científico e Tecnológico (CNPq) e à Organização Pan-Americana de Saúde/Brasil pelo apoio financeiro.

Ao Victor Jun Arai, à Katia Porteiro, da Faculdade de Saúde Pública, e ao Marcelo Correia Peixoto, à Eugênia Ribeiro, à Jinadiene da Silva Soares, à Maria Lucymar da Silva Soares, da Universidade Federal de Alagoas, que trabalharam no apoio à pesquisa.

À Universidade Federal de Alagoas, especialmente ao professor Gonçalo Tavares Dória do Núcleo de Saúde Pública (NUSP), pelo acolhimento e ajuda.

Aos meus amigos da Faculdade de Saúde Pública, Ana Maria Caricari, Cláudia Maria Bógus, Emílio Telesi Júnior, Francisco Comaru, Luciana Ribeiro e Paulo Fernando Capucci, pela ajuda e solidariedade.

À Betania, ao Fernando e à Oneide, de Alagoas pelo apoio e amizade.

Aos meus amigos Rita, Mary, Lalá e ao pequeno Guilherme, pelo carinho em todos os momentos.

Ao Laps pela amizade, carinho e pela cuidadosa edição deste trabalho. inglês.

À Luiza pela contribuição na revisão do texto e na redação do resumo em

À biblioteca da Faculdade de Saúde Pública, pelo auxílio na revisão bibliográfica. 


\section{RESUMO}

Mendes R. Cidades Saudáveis no Brasil e os processos participativos: os casos de Jundiaí e Maceió. São Paulo; 2000. [Tese de doutorado- Faculdade de Saúde Pública da USP].

O objetivo deste trabalho é analisar os processos participativos em cidades brasileiras que desenvolvem projetos de acordo com o ideário por Cidades Saudáveis. O movimento Cidades Saudáveis fomentado pela Organização Mundial de Saúde desde 1986, objetiva o estabelecimento de políticas públicas urbanas, voltadas à melhoria da qualidade de vida, com ênfase na intersetorialidade e na participação social. $O$ presente estudo é qualitativo, realizado com base na coleta e análise de dados secundários, de entrevistas e de grupos focais, o que permitiu caracterizar, em primeiro lugar, a situação dos projetos Cidades Saudáveis no Brasil, seus processos de implantação e desenvolvimento, e, em segundo lugar, verificar os avanços e retrocessos na relação sociopolítica estabelecida entre o poder público e os grupos sociais envolvidos nesses projetos. Pode-se observar que os projetos Cidades Saudáveis vêm se desenvolvendo no Brasil de diferentes maneiras, e seus avanços são bastante restritos. As propostas são frágeis e estão relacionadas a dificuldades de implementar novas formas de gestão, participativas, não setorizadas, capazes de alterar as estruturas políticas, sociais e econômicas. Esta fragilidade faz com que os projetos não se sustentem nas mudanças administrativas. Os estudos de caso, nas cidades de Jundiaí, Estado de São Paulo, e Maceió, capital do Estado de Alagoas, mostraram que as condições gerais políticas das cidades não favorecem a participação efetiva dos cidadãos nas questões que envolvem as condições de vida. $O$ aspecto contraditório das relações Estado/sociedade civil fica evidenciado. A participação existe, é reconhecida pelo Estado que abre um espaço institucional para que ela ocorra, no entanto, os grupos sociais não têm conseguido penetrar nos espaços de poder, o que aponta uma série de limites relacionados desde à cultura institucional marcada por estruturas tradicionais e autoritárias que dificultam a participação, até os conflitos próprios do processo de organização da sociedade civil.

Descritores:Cidades Saudáveis. Participação da População. Municípios Saudáveis. Promoção da Saúde. 


\section{SUMMARY}

Mendes R. Cidades Saudáveis no Brasil e os processos participativos: os casos de Jundiaí e Maceió. [Healthy Cities in Brazil and process of participation: a case study of Jundiaí and Maceió]. São Paulo (BR); 2000. [Tese de doutorado- Faculdade de Saúde Pública da USP].

The aim of this work was to analyse the process of participation in the project Healthy Cities developed in Brazilian cities. This kind of project has been fostered by WHO since 1986, to promote public urban policies able to improve the quality of life by emphasizing the intersectoral action and social participation. This is a qualitative study based on data collection and analysis from interviews and focal groups which allowed identifying the implementation, process of development as well as the present situation of the project Healthy Cities in Brazil, to evaluate the progress and hindrances in the social political relationship among the public sphere and the social groups involved. The projects Healthy Cities have been developed in different ways in Brazil and there has been very little progress in the direction of changing the political, social and economical structures. The proposals are flimsy, usually related to the difficulties of implementing new participant and intersectoral models of management. As a consequence of such a fragility the projects are interrupted when administrative changes occur. The case studies developed in two Brazilian cities, Jundiaí in the state of São Paulo, and Maceió, capital of the state of Alagoas, showed that the general political conditions in the cities do not stimulate the effective community participation in issues related to life conditions. The contradictory aspect in the State/community relations becomes evident. Although the State offers institutional conditions for the community participation, the social groups are not granted the power, and that shows their limits related to institutional culture rooted in traditional and authoritarian structures hampering participation as well as the conflicts related to the process of civil organization.

Descriptors:Healthy Cities. Community participation. Healthy Municipalities. Health Promotion. 


\section{Í N D I C E}

INTRODUÇÃO 1

1. PROMOÇÃO DA SAÚDE E O MOVIMENTO POR CIDADES SAUDÁVEIS ......................... 6

Introdução ao debate: urbanização, qualidade de vida e eqüidade.............................................. 6

O movimento por Cidades Saudáveis: uma política pública saudável na busca da eqüidade... 11

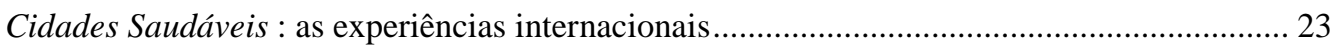

2. PARTICIPAÇÃo NAS POLÍTICAS PÚBLICAS SAUdÁVEIS ............................................ 29

Descentralização, intersetorialidade e participação ................................................................ 29

Implementação de políticas públicas saudáveis: o papel do Estado e da sociedade civil ......... 36

Participação nos projetos Cidades Saudáveis ........................................................................ 44

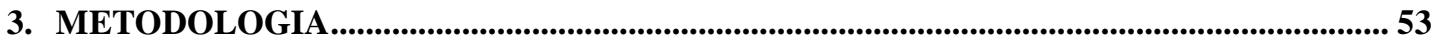

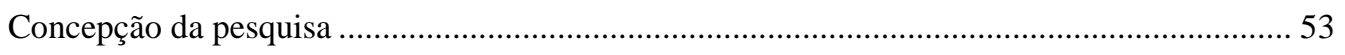

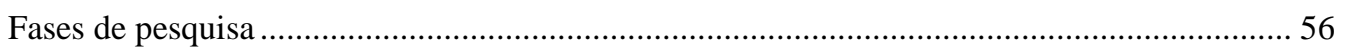

Fase: 1: Estimativa Rápida dos projetos Cidades Saudáveis no Brasil.................................... 56

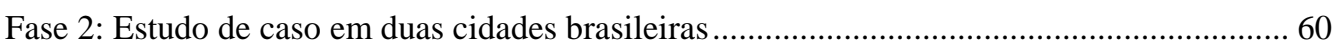

4. AS CIDADES/MUNICÍPIOS SAUDÁVEIS NO BRASIL............................................................66

O início do movimento por Cidades/Municípios Saudáveis no Brasil........................................ 66

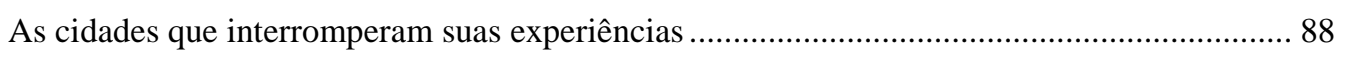

As cidades que se aproximaram do movimento .................................................................. 92

As cidades com experiências em andamento ...................................................................... 94

5. AS EXPERIÊNCIAS DE JUNDIAÍ E MACEIÓ COM ENFOQUE NOS PROCESSOS

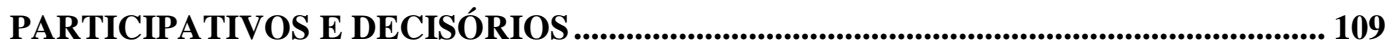

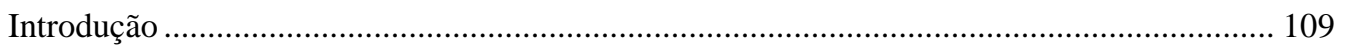

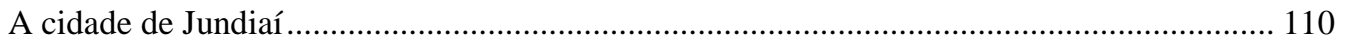

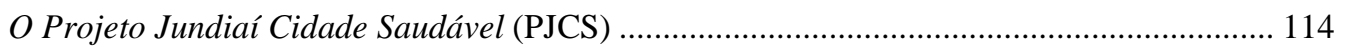

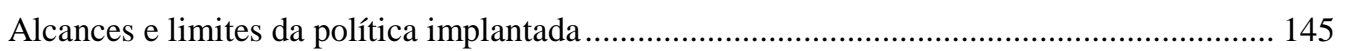

Comunidades Saudáveis em Maceió: Pontal da Barra e Cruz das Almas................................ 150

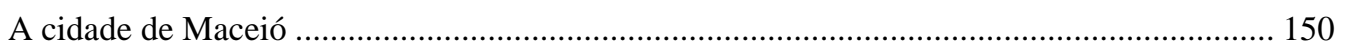

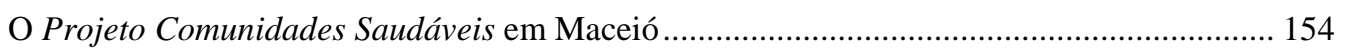

O Projeto Comunidade Saudável no Pontal da Barra ............................................................... 161

O Projeto Comunidade Saudável em Cruz das Almas: comunidades Grotas do Arroz e do São

Rafael e Loteamento Santo Onofre ...................................................................................... 176

Alcances e limites da política implantada em Maceió ........................................................... 185

6. CIDADANIA, DEMOCRACIA E OS DESAFIOS DA GESTÃO COMPARTILHADA .... 188

Criação de mecanismos de garantia de acesso à informação .................................................... 190

Educação para a cidadania para ampliar os canais de participação........................................... 192 
Articulação entre as instâncias de participação.

Avaliação e o acompanhamento dos projetos ................................................................... 196

Manutenção dos projetos e a necessidade de ampliar alianças ........................................... 198

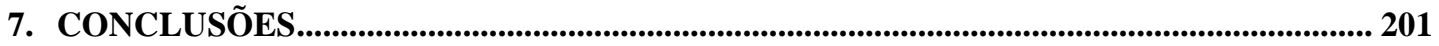

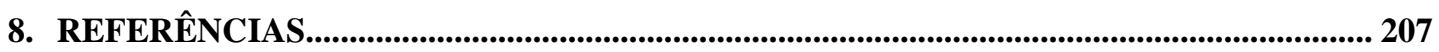

Jornais da Cidade de Jundiaí ....................................................................................... 213

Anexo 1 - Roteiro de Estimativa Rápida.......................................................................... 1

Anexo 2 -Quadros ilustrativos da construção do Discurso do Sujeito Coletivo (DSC) .............. 2

Anexo 3 - Integra dos discursos do sujeito coletivo ........................................................ 5

Anexo 4 - Roteiro de entrevistas individuais de acordo com os grupos pesquisados.............. 13

Anexo 5 - Grupo Focal - Instruções Gerais e Roteiro ........................................................ 14

Anexo 6 - Parcerias Referidas nos Projetos Cidades Saudáveis no Brasil .............................. 16 


\section{INTRODUÇÃO}

O delineamento de estratégias no campo da Promoção da Saúde é recente em todo o mundo, dentre elas, aquelas denominadas Cidades Saudáveis. Esses projetos, que se disseminam por vários países, tentam responder a mudanças decorrentes da globalização, da urbanização acelerada, dos arranjos políticos e institucionais. Com base no pressuposto de que a saúde é produzida socialmente, o ideário por Cidades Saudáveis advoga superar as práticas de saúde centradas na atenção médica curativa $^{1}$, para buscar a globalidade de fatores que determinam a saúde. Apresenta, ainda, como prioridade na definição das políticas públicas, incluir a saúde como critério de governo.

A complexidade dos problemas colocados nessa perspectiva exige o tratamento de forma integrada e sistêmica das questões. Nesse sentido, ganham destaque dois componentes: a intersetorialidade e a integração das esferas públicas com as organizações da sociedade civil. Esta combinação, no entanto, não é nova no campo da saúde. As ações implementadas com base na concepção de saúde como qualidade de vida já propunham modificações nos enfoques tradicionais de atenção primária e incluíam esses aspectos na operacionalização de ações de saúde no nível local. O fato de se propugnar a definição de políticas públicas saudáveis nas estratégias de Promoção da Saúde, tal como se apresentam no ideário por Cidades Saudáveis, entretanto, leva a uma ampliação do alcance das políticas, que não se resumem apenas a investimentos em políticas setoriais de saúde.

Nessa visão, o locus da cidade é considerado um campo privilegiado de ação, que pode permitir a implementação de iniciativas inovadoras, com a inclusão de atores sociais locais no estabelecimento de políticas.

Este último aspecto merece atenção, especialmente porque a inclusão de amplos setores da sociedade civil na formulação, implementação e controle das

\footnotetext{
${ }^{1}$ MENDES (1996), critica a prática da atenção médica curativa que toma o conceito de saúde na sua negatividade. Esta prática, por estar estruturada a partir do paradigma flexneriano, que se expressa por um conjunto de elementos, como o mecanicismo, o biologismo, o individualismo, a especialização, a
} 
Cidades Saudáveis no Brasil e os processos participativos: os casos de Jundiaí e Maceió

políticas, têm conseqüências muito importantes para o desenvolvimento de projetos sociais. No Brasil, este processo é muito recente e tem relação com o processo de democratização. Historicamente, os atores sociais advindos de grupos comunitários e associações sempre estiveram à margem da definição de políticas públicas, sob forte gerência de um Estado burocrático, com tradição política paternalista e clientelista. No entanto, é na cidade, como diz IANNI (1996), que "o indivíduo pode perceber mais limpidamente a cidadania”. Esse exercício exige, contudo, reconhecer a existência de campos de negociação e conflitos na prática cotidiana.

São inúmeras as dimensões que o tema da participação suscita no setor da saúde, no entanto, na perspectiva da Promoção da Saúde, outros elementos podem ser agregados àqueles já tradicionalmente considerados. Quando se refere aos projetos Cidades Saudáveis, a participação, em suma, diz respeito a um processo por meio do qual os grupos comunitários, organizações, instituições, intervêm para identificar problemas e propor ações de mudanças. Em outras palavras, a participação se traduz como gestão participativa.

Desvendar como essa gestão compartilhada se delineava nos projetos Cidades Saudáveis passou a ser, desde o início desta investigação, o objeto de estudo. Uma primeira dificuldade encontrada era a ausência de um estudo mais sistemático sobre o movimento por Cidades Saudáveis no Brasil. De fato, poucos documentos foram produzidos, poucas reflexões realizadas. Compreendemos, então, que o trabalho deveria começar pela ordenação de um conjunto de informações dispersas, entendendo por "ordenação" o estabelecimento de relações, a fim de detectar um fio diretor do tema. Na fase inicial de pesquisa, os problemas a serem discutidos e analisados, porém, apresentaram-se muito amplos, e embora pudessem ser relacionados entre si, poderiam se constituir em outros estudos. Basicamente, optamos por centrar esta primeira etapa de investigação nas seguintes questões: Cidades Saudáveis no Brasil, como política de gestão urbana: em que locais ocorrem? em que contexto surgem? quais são os pressupostos que as sustentam? Como vêm se desenvolvendo? 
Cidades Saudáveis no Brasil e os processos participativos: os casos de Jundiaí e Maceió

Com base nos primeiros levantamentos realizados, pudemos nos centrar em nosso foco de interesse: como a participação estava inscrita nesses projetos? A escolha desse tema para o desenvolvimento deste estudo foi motivada, em primeiro lugar, pela constatação da demanda, cada vez maior, por participação política e pela crescente insatisfação com a representação de mecanismos tradicionais, que historicamente vêm sendo definidos no estabelecimento de políticas sociais de interesse público; em segundo lugar, pela precariedade de estudos em torno do conceito de participação na perspectiva da Promoção da Saúde e das práticas decorrentes; e, em terceiro, pela dúvida em relação ao prestígio que desfruta o tema da participação, como sendo capaz de solucionar os complexos problemas no campo das políticas públicas.

Outras indagações foram se delineando como eixos condutores da pesquisa: seriam os processos advindos de negociações participativas, conforme proposto na construção de políticas públicas saudáveis, capazes de encaminhar soluções no sentido de redirecionar políticas públicas socialmente relevantes ? Seriam capazes de motivar a aproximação entre os diferentes setores de governo, a fim de racionalizar as decisões e otimizar os recursos para executá-las? Esses processos estariam contribuindo para que a população se tornasse protagonista nas políticas públicas implementadas? Estariam esses processos contribuindo para o empowerment da população, entendido como ganho de poder político para atuar efetivamente na transformação de suas vidas e de seus ambientes? E, finalmente, estariam as cidades se organizando como locus que respondem à Promoção da Saúde, como um conjunto de ações intersetoriais e participativas, que visam repercutir na qualidade de vida dos cidadãos?

Com o intuito de responder às questões relacionadas aos processos de gênese dos projetos Cidades Saudáveis, em geral, e às dos processos participativos em particular, optamos pela busca de um referencial que pudesse dar conta da complexidade do objeto, que passa pelo entendimento da estruturação do movimento contemporâneo por Cidades/Municípios Saudáveis, dos conceitos que o sustenta, das práticas que lhe dá concretude e das interações que se delineiam. 
Definimos como objetivos deste estudo:

Objetivo Geral:

Analisar e avaliar limites, possibilidades e avanços, advindos da definição de processos participativos, que ocorrem no delineamento e no gerenciamento de políticas públicas nos projetos Cidades Saudáveis.

\section{Objetivos Específicos:}

1. Identificar e caracterizar os projetos Cidades Saudáveis conhecidos no Brasil, observando os processos de desenvolvimento;

2. Analisar avanços e retrocessos na relação sociopolítica-educacional estabelecida entre autoridades locais e grupos sociais envolvidos em dois Projetos Cidades Saudáveis no Brasil, observando:

- fortalecimento da população e mudança nas relações de poder;

- avanços e retrocessos na relação sociopolítica;

- interferência do contexto socioeconômico-cultural na relação política;

- equacionamento e soluções dos problemas na perspectiva intersetorial;

- conseqüências para a saúde e qualidade de vida da população.

Este estudo está estruturado em sete capítulos nos quais procuramos refletir sobre as questões problematizadas. No primeiro, analisamos o debate que relaciona a crescente urbanização aos reflexos na qualidade de vida das populações. Nesse contexto, é focalizado o surgimento do movimento por Cidades Saudáveis, como uma estratégia de Promoção da Saúde, tanto nos países desenvolvidos como nos da América Latina. No segundo capítulo, discutimos os conceitos que sustentam o ideário por Cidades Saudáveis, a descentralização, a intersetorialidade, o papel do Estado, articulados ao componente considerado fundamental e um dos pilares de sustentação do movimento: a participação. No terceiro capítulo, indicamos a concepção da pesquisa e descrevemos os procedimentos metodológicos adotados. No quarto capítulo, analisamos o surgimento do movimento por Cidades Saudáveis no Brasil, e as principais características que os projetos assumem. São apresentadas as experiências em andamento, aquelas que se aproximam do movimento, bem como as cidades que interromperam suas ações. No quinto capítulo, aprofundamos a análise de duas cidades, focalizando os processos participativos. As cidades brasileiras, 
Cidades Saudáveis no Brasil e os processos participativos: os casos de Jundiaí e Maceió

Jundiaí, no Estado de São Paulo, e Maceió, capital de Alagoas, foram selecionadas para estudo de caso. Procuramos identificar, nesses projetos, os atores locais envolvidos, recuperar através deles o histórico dos projetos, bem como entender os processos interativos que se delineiam. Os desafios para implementar projetos Cidades/Comunidades Saudáveis são apontados no sexto capítulo, em que retomamos as discussões teóricas iniciais, procurando indicar a possibilidade de instituição de novos arranjos, que reúnam os diversos atores e que permitam a construção de políticas relevantes, de longo prazo e sustentadas por pressupostos democráticos. Por último, apresentamos as principais conclusões com base nos objetivos propostos.

Finalmente, é preciso considerar que este trabalho é fruto de uma vivência bastante intensa no movimento por Cidades Saudáveis, que vem se estabelecendo no Brasil e na América Latina. Este trabalho foi elaborado em etapas e seus resultados puderam ser divulgados parcialmente em diversos fóruns ${ }^{2}$, com importantes contribuições que puderam ser incorporadas nas análises.

\footnotetext{
${ }^{2}$ Os fóruns internacionais, onde os resultados parciais desse trabalho puderam ser divulgados, foram: XVI Conferência Mundial de Promoción de la Salud y Educación para la Salud, 1998 - San Juan, Puerto Rico; Congresso Latinoamericano sobre Municípios Saludables, 1999 - .Medellin, Colombia; Taller de Evaluación de Municipios Saludables, 1999 - Washington (DC), EUA. Estágio: Québec Network Healthy Cities and Towns; 1998 - Québec, Canadá. Dentre os seminários e conferências nacionais destacamos: I Fórum Alagoano de Municípios Saudáveis, 1998 - Maceió, Alagoas; Conferência Municipal de Flexeiras, 1999 - Flexeiras, Alagoas; V Congresso Paulista de Saúde Pública, 1999 - Águas de Lindóia, São Paulo; I Fórum de Promoção da Saúde do CONASEMS, 2000Brasília (DF).
} 
Cidades Saudáveis no Brasil e os processos participativos: os casos de Jundiaí e Maceió

\section{PROMOÇÃO DA SAÚDE E O MOVIMENTO POR CIDADES SAUDÁVEIS}

\section{INTRODUÇÃO AO DEBATE: URBANIZAÇÃO, QUALIDADE DE VIDA E EQÜIDADE}

O debate em torno da articulação entre as instituições públicas e as organizações da sociedade civil tem uma significativa importância nos dias de hoje, quando se busca a mobilização em torno de projetos comuns, de interesses coletivos e, particularmente, quando se toma como foco as cidades, como estratégia para a Promoção da Saúde, com o objetivo de repercutir na qualidade de vida dos cidadãos.

Esta temática faz emergir um série de questões, que convergem para reflexões acerca da urbanização e para as oportunidades de vida da população; das formas de gestão capazes de contribuir para redefinição e redistribuição de competências e recursos públicos; do processo de redefinição do papel do Estado, tendo uma de suas características a revalorização do poder local e incentivo a programas negociados com a participação da população. Fica evidente, assim, o protagonismo que as cidades vêm ganhando nos últimos anos.

É difícil definir uma cidade. PARK $(1976)^{3}$, reconheceu que a cidade é mais do que um "amontoado" de homens, ruas, edifícios, linhas de bonde, telefones, etc. Por estar envolvida nos processos vitais das pessoas que a compõem, a cidade deveria ser encarada como um produto da natureza humana, e não apenas como uma "unidade geográfica e ecológica". O autor confere, também, à cidade o status de "unidade econômica", em que as pessoas, com todos os dispositivos de administração e maquinaria estão organicamente relacionadas.

Com as rápidas mudanças verificadas neste último século, na estrutura e organização da sociedade, deparamo-nos, contudo, com as comunidades, as cidades, as metrópoles, as megalópoles, como fenômenos de urbanização, que se expressam através da economia, da cultura, do governo, da política, da infra-estrutura social e física, das relações de troca e de comunicação, havendo necessidade, portanto, de entender a cidade não somente como território limitado que concentra pessoas e uma grande diversidade de atividades.

\footnotetext{
${ }^{3}$ Trabalho publicado em 1916, traduzido por Sérgio Magalhães Santeiro e inserido no livro O fenômeno urbano, organizado por Otávio Guilherme Velho e publicado em 1976.
} 
Cidades Saudáveis no Brasil e os processos participativos: os casos de Jundiaí e Maceió

Para IANNI (1996), nesse fim de século, o desenvolvimento e expansão do capitalismo, em escala mundial, está influenciando o aparecimento de um outro tipo de cidade: a "cidade global". Constitui-se em densas regiões urbanizadas, com forte controle econômico, fortemente ligadas entre si, formando novas redes de articulações, por meio das quais se configura as possibilidades do capitalismo global. É o lugar onde tudo se experimenta, "da democracia e tirania, da racionalização $e$ alienação, da cidadania e anomia", onde se afirma a "diversidade" e também a "desigualdade"; onde se articulam o "real e o imaginário".

Ao mesmo tempo que a globalização constitui uma tendência neste final de século, DOWBOR (1999), chama a atenção para o surgimento de "espaços subnacionais fracionados", que se concretizam na redefinição dos papeis econômico, social e político das metrópoles e das cidades e na gradual reconstituição, dos espaços locais, e de um ser humano mais integrado.

CASTELLS e BORJA (1996), ao traçarem os contornos da problemática das cidades, fornecem outros elementos para a discussão. A cidade deve ser vista, segundo eles, como um "espaço simbiótico", onde o poder político e a sociedade civil negociam políticas de desenvolvimento urbano, e como um "espaço simbólico" que integra culturalmente, dá identidade coletiva, dinamiza as relações, convertendo a cidade num espaço de respostas possíveis aos propósitos econômicos, políticos e culturais de nossa época. Assim, a cidade tem assumido o papel de "ator social".

Os movimentos contemporâneos, como o das Eurocidades, que reúne cerca de cinqüenta cidades da Europa; as redes das cidades asiáticas; os projetos delineados pelas cidades americanas; os movimentos político-sociais do Leste Europeu e das cidades da América Latina, refletem, para os autores, a importância das cidades como "protagonistas econômicos, sociais e políticos" que buscam, guardando suas particularidades, renovar suas bases produtivas, reordenar seus mercados, criar projetos estratégicos de desenvolvimento econômico e urbano, implementar projetos que tenham por princípio a "inovação democrática" que responde à participação dos cidadãos, à cooperação social e à integração das políticas urbanas. 
Cidades Saudáveis no Brasil e os processos participativos: os casos de Jundiaí e Maceió

Seja em contextos das cidades de países desenvolvidos, seja no caso de cidades latino-americanas, percebe-se a existência cada vez maior de projetos de transformação urbana. CASTELLS e BORJA (1996), mostram bem isso, quando analisam e comparam a problemática que leva as diferentes cidades do mundo a estabelecerem planos de amplo "consenso social". Para eles, as grandes cidades devem gerar capacidade de resposta à nova base econômica, à infra-estrutura urbana, à qualidade de vida, à integração social e à governabilidade, e somente assim podem se tornar competitivas e dar, ao mesmo tempo, garantias de bem-estar a sua população.

Grandes cidades européias, mediante vastos planos estratégicos, muitas vezes tendo que ser definidos a partir da realização de grandes eventos internacionais, investiram em relevantes projetos urbanos. Vivendo uma problemática diferenciada, as cidades da América Latina enfrentam outras questões decisivas, como o crescimento demográfico, o peso da marginalidade social, o déficit de infra-estrutura moderna e a fraqueza dos governos locais. Estes fatos reforçam a necessidade de democratização e descentralização dos Estados, o estabelecimento de objetivos e ações coletivas e articulação de amplos setores da sociedade.

Quando nos referimos à implantação de políticas urbanas e seus impactos social e político, especialmente nos países da América Latina, não podemos deixar de destacar o fenômeno da urbanização. O rápido processo de urbanização ocorrido nas últimas décadas fez com que, nos últimos 50 anos, os países deixassem de ter características rurais para se tornarem urbanos. A velocidade imposta pela urbanização nos coloca frente a um grande desafio, de que nos próximos 15 anos, 20 a 30 cidades do mundo terão uma população superior a 20 milhões de habitantes. No fim desta década, o mundo terá cerca de $50 \%$ da população vivendo em áreas urbanas. O quadro mais dramático deverá ser enfrentado pelos países em desenvolvimento, como o Brasil, cujo processo demográfico, da maneira como vem ocorrendo, faz com que os índices de urbanização sejam alarmantes. De acordo com SANTOS (1996), o período de inversão de residência da população brasileira se dá entre 1940 e 1980, quando a taxa de urbanização saltou de 26,35\%, alcançando em 1980, a cifra de 68,86\%, e, em 1991, atingiu, 77,13\%. Espera-se que, até o ano 2000, 
Cidades Saudáveis no Brasil e os processos participativos: os casos de Jundiaí e Maceió

a população brasileira que vive em áreas urbanas deva ser de aproximadamente 136 milhões de pessoas, representando 80\% do total populacional (TASCHNER 1992).

O atual padrão de urbanização brasileiro é amplamente discutido no estudo caracterização e tendências da rede urbana no Brasil do IPEA/IBGE/UNICAMP (1999). Os dados apresentados chamam a atenção para as tendências da urbanização no país, onde ocorre uma configuração de diversas espacialidades que formam a complexa rede urbana brasileira, reflexo de distintas articulações socioespaciais que se formam entre as cidades. Essa complexidade se expressa na descontração de atividades produtivas e no surgimento de novos espaços economicamente dinâmicos: "as aglomerações urbanas metropolitanas e aglomerações urbanas nãometropolitanas" que vão determinar as tendências econômicas, os novos investimentos produtivos, a expansão de serviços, etc.

Não se trata, portanto, de uma questão apenas demográfica. A urbanização está inserida num contexto macroeconômico que envolve uma combinação de fatores sociais, econômicos e políticos.

O tema qualidade de vida relacionado ao crescimento das cidades merece atenção, especialmente pelo fato de a maioria dos países, onde vivem milhões de pessoas, não atenderem sequer às necessidades básicas de sobrevivência de suas populações. A determinação da qualidade de vida tem sido relacionada por diversos autores, de acordo com WESTPHAL (2000), a fatores objetivos e fatores subjetivos. Os primeiros estariam referidos às condições materiais necessárias a uma sobrevivência livre da miséria, e os segundos, à questões como a necessidade de se relacionar, sentir-se integrado socialmente. Em nossa realidade há, no entanto, necessidade de se levar em conta ambos os fatores na constituição de um conceito de qualidade de vida, que articule às reais condições de existência de uma população e ao acesso aos bens de cidadania (como bens e serviços, moradia, alimentação, lazer), outros aspectos, como a formação de identidades sociais, ampliação do acesso ao espaço político, participação nas decisões políticas e outros.

Também as condições inaceitáveis de iniqüidade, associadas à distribuição de recursos econômicos e ao acesso à equipamentos sociais, ameaçam a qualidade de vida das populações. A América Latina, em âmbito internacional, é considerada a 
Cidades Saudáveis no Brasil e os processos participativos: os casos de Jundiaí e Maceió

região do mundo com os mais elevados índices de desigualdade. KLIKSBERG (1998), analisou a distribuição de renda nos últimos 20 anos, nas diferentes regiões do mundo, e observou que a distância entre os estratos mais extremos de riqueza e pobreza, da estrutura social, aumentou significativamente nesse período, na América Latina. Em 1990, enquanto os $20 \%$ da população mais rica detinham $52,94 \%$ da renda, proporção muito superior a outras regiões do mundo, como a África do Norte e o Oriente Médio, os $20 \%$ mais pobres, $(45,35 \%)$, só tinham acesso a 4,52\% da renda.

O Brasil é o caso clássico de desenvolvimento desigual, em que um pequeno segmento da população tem acesso a uma grande parte de bens e serviços, enquanto outra, bastante elevada, está excluída de bens básicos de sobrevivência (WESTPHAL 2000). A evolução da distribuição de renda no país atesta esta situação. No período que vai de 1970 a 1994, a renda nacional de 1\% da população mais rica passou de $8 \%$ para $15 \%$, enquanto a renda dos $25 \%$ mais pobres, diminuiu, passando de $16 \%$ para 12\% (KLIKSBERG 1998).

Esses altos percentuais de pobreza, de desigualdade social e econômica sem precedentes, criam profundas segregações e dificuldades estruturais para as sociedades, em múltiplos planos da vida cotidiana, como por exemplo, no acesso à terra, à educação, ao trabalho, à saúde, à informação. Os processos sociais que criam as iniqüidades obstruem o desenvolvimento social, limitam e reduzem a participação dos pobres no crescimento, geram sérias tensões sociais, e tendências desestabilizadoras (KLIKSBERG 1998).

Há, no entanto, a crença de que as iniqüidades podem ser enfrentadas, e não constituem uma espécie de fatalidade histórica inexplorável. Este enfrentamento sugere, de acordo com WESTPHAL e ZIGLIO (1999), definir, antes de tudo, o projeto social que se quer construir e os valores que se quer defender. Nesse sentido, os autores propõem uma revisão na concepção do processo de desenvolvimento social, que necessariamente deve estar centrada no cidadão e em suas necessidades. Isto exige a busca de articulação entre desenvolvimento social e humano e incorporação de eixos de análise voltados às condições de qualidade de vida, de exercício de direitos e de desenvolvimento de capacidades. 
Cidades Saudáveis no Brasil e os processos participativos: os casos de Jundiaí e Maceió

O desafio está em buscar modelos de políticas que combinem as exigências de crescimento e o enfrentamento do quadro de exclusão social.

\section{O MOVIMENTO POR CIDADES SAUDÁVEIS: UMA POLÍTICA PÚBLICA SAUDÁVEL NA BUSCA DA EQÜIDADE}

A intenção de enfocar a relação da saúde com a totalidade da vida - com o contexto geral - encontra amparo no capítulo sobre Saúde, da Constituição Federal Brasileira de 1988, que a define no sentido positivo. Aproximando-a das proposições relativas à da qualidade de vida, a saúde deve ser observada a partir da interlocução com outras áreas, buscando a integralidade da ação social. As políticas de saúde que vêm sendo delineadas, desde então, têm reafirmado o pressuposto da descentralização e a importância dos sistemas locais de saúde, considerados como cenários de integração de diversos atores sociais para o desenvolvimento da saúde e como um conjunto de procedimentos que não devem se restringir apenas à prestação de serviços. Assim, os serviços de saúde devem ser organizados com vistas a possibilitar a participação cotidiana dos cidadãos na gestão pública e no controle das condições que podem interferir na sua saúde e da coletividade onde vive e trabalha.

Este movimento que vem se dando no Brasil não é isolado, ao contrário, acompanha políticas e diretrizes no campo da saúde pública que vão sendo redefinidas mundialmente no que tem sido considerado o campo da Promoção da Saúde. A Promoção da Saúde surge como uma reação à medicalização da saúde, na sociedade e no interior do sistema de saúde, e tem, no atual contexto um marco de referência mais amplo do que o enfoque usado para caracterizar um nível de atenção da medicina preventiva, conforme definido por Leavell \& ClarK, no esquema da História Natural das Doenças. É considerada um instrumental conceitual, político e metodológico em torno do processo saúde - doença, que visa analisar e atuar sobre as condições sociais que são críticas para melhorar as condições de saúde e de qualidade de vida (CERQUEIRA 1997; BUSS 1998).

As estratégias da Nova Promoção da Saúde têm seu desenvolvimento, como movimento ideológico e social, de forma mais intensa, nos últimos 20 anos, no Canadá, Estados Unidos e países da Europa Ocidental, com avanços mais lentos na América Latina e Caribe. As Conferências Internacionais, a partir da Primeira Conferência Internacional de Promoção da Saúde realizada em Ottawa, em 1986, têm 
Cidades Saudáveis no Brasil e os processos participativos: os casos de Jundiaí e Maceió

difundido conceitos básicos que exigem a revigoração da saúde pública em torno do compromisso de saúde para todos. As discussões de Ottawa tiveram como parâmetros a Declaração de Alma-Ata para os Cuidados Primários em Saúde (1978) e debates posteriores realizados ao redor do mundo. O tema da Conferência de Ottawa centrou-se na reconceituação de saúde e de Promoção da Saúde.

É importante destacar, aqui, alguns pontos: o primeiro é que começa a se delinear um "novo paradigma de saúde": a saúde é produzida socialmente, assim, a Promoção da Saúde está relacionada a um conjunto de valores: vida, saúde, solidariedade, eqüidade, democracia, cidadania, participação, parceria, desenvolvimento, justiça social, revalorização ética da vida. Portanto, relaciona as determinações da saúde ao impacto das dimensões sociais, culturais, econômicas e políticas nas coletividades para alcançar um desenvolvimento social mais eqüitativo. Ressalta-se, ainda, a combinação de estratégias, ou seja, a Promoção da Saúde demanda uma ação coordenada entre os diferentes setores sociais, ações do Estado, da sociedade civil, do sistema de saúde e de outros parceiros intersetoriais. Em suma, a saúde não é assegurada apenas pelo setor da saúde. Observa-se, ainda, um forte componente internacionalista presente nos documentos, Cartas e Conferências, que definem sua natureza política (BUSS 1998).

As cinco estratégias que são definidas e apresentadas na Carta de Ottawa resumem as diretrizes e pressupostos da Promoção da Saúde: elaboração e implementação de políticas saudáveis; criação de ambientes favoráveis à saúde; apoio e participação da comunidade; desenvolvimento de habilidades individuais; reorientação dos sistemas e serviços de saúde (OTTAWA CHARTER 1987).

Como a saúde é entendida a partir de seus determinantes sociais, há de se promover uma responsabilidade social para com ela. Os encontros e as conferências subsequentes relacionados ao tema, especialmente as Conferências Internacionais realizadas em Adelaide, na Austrália, em 1988, em Sundsvall, na Suécia, em 1991, e finalmente, em Jakarta, em 1997, procuram reafirmar as Conferências de Alma-Ata e Ottawa, ressaltar a necessidade de se adotarem propostas de intervenção inovadoras e mais abrangentes na implementação de políticas públicas saudáveis. A Carta de Adelaide, de 1988, define as políticas públicas saudáveis como o interesse de todas 
Cidades Saudáveis no Brasil e os processos participativos: os casos de Jundiaí e Maceió

as áreas das políticas públicas em relação à saúde e eqüidade e pelos compromissos com o impacto dessas políticas sobre a saúde da população (OMS 1996).

Na formulação de políticas públicas saudáveis, todos os setores de governo devem direcionar sua atuação tendo como perspectiva que a saúde é um aspecto essencial da vida. As prioridades para a Promoção da Saúde no século XXI foram debatidas na IV Conferência Internacional em JaKarta, em que o elemento mais destacado foi a necessidade de criação de parcerias e alianças com todos os setores da sociedade.

Na América Latina a introdução da reconceituação da Promoção da Saúde e o estabelecimento de estratégias de desenvolvimento de ações nos países em desenvolvimento, deu-se com a Conferência de Promoção da Saúde realizada em Santa Fé de Bogotá em 1992. A iniqüidade sem precedentes da América Latina, agravada pela crise econômica e pelos programas das políticas de ajuste macroeconômico, a situação política que limita o exercício da democracia e a participação pela cidadania, foram considerados fatores determinantes na garantia de condições de saúde e vida das populações.

As ações de Promoção da Saúde concretizam-se em diversos espaços, em órgãos definidores de políticas, nas universidades e, sobretudo, localmente, nos espaços sociais onde vivem as pessoas. As cidades, os ambientes de trabalho e as escolas são os locais onde essas ações têm sido propostas. Com o objetivo de fortalecer o protagonismo do nível local e definir ações de Promoção da Saúde nas cidades, foi implementada a estratégia Cidades Saudáveis. A proposta por Cidades Saudáveis, fundamenta-se basicamente numa visão de saúde como qualidade de vida. Focaliza, ainda, a dimensão intersetorial e participativa na busca de mudanças na forma de gestão dos diferentes níveis de governo, sobretudo o municipal.

Os argumentos para a implementação de projetos no âmbito das cidades são diversos. Um deles está relacionado à implicação imediata da crescente urbanização e seu impacto sobre as condições de saúde da população. Embora a vida na cidade seja considerada atraente, pela promessa de melhores oportunidades de trabalho e acesso aos bens de consumo e serviços, acarreta, também, inúmeros problemas, especialmente quando a aglomeração de população cresce a tal ponto, que as pessoas 
ficam expostas a uma variedade de riscos à saúde e não têm acesso a recursos para o atendimento de suas necessidades básicas. Os problemas estão mais comumente relacionados ao abastecimento de água, habitação, poluição, destino dos dejetos sólidos, marginalidade, violência.

Para GOLDSTEIN e KICKBUSCH (1996), as estimativas agravam essa situação. Prevê-se que, neste final de século, pelo menos 600 milhões de pessoas das áreas urbanas de países em desenvolvimento, estejam vivendo em condições de risco de vida e risco à saúde, sob situações de estresse e expostas a uma ampla variedade de problemas de saúde, como doenças transmissíveis, desnutrição, doenças mentais, doenças respiratórias crônicas. As condições não saudáveis incluem a pobreza, a alimentação inadequada, a insegurança, condições inadequadas de trabalho, o uso excessivo de substâncias nocivas e a poluição ambiental.

Os documentos e artigos mais recentes acerca do tema Cidades Saudáveis, especialmente aqueles publicados pela Organização Pan-Americana de Saúde OPAS (ou PAHO, Pan American Health Organization) e Organização Mundial da Saúde - OMS (ou WHO, World Health Organization) ${ }^{4}$ têm procurado justificar a adoção de projetos Cidades Saudáveis baseadas na análise da situação social, sobretudo dos países em desenvolvimento, onde as desigualdades geradas pelo modelo de desenvolvimento têm aumentado os níveis de pobreza e a informalização da economia tem crescido assustadoramente. Predominam cenários de instabilidade política, de carências sociais e de debilidade, associadas à capacidade insuficiente das instituições que suportam as estruturas da sociedade de atenderem e resolverem esses problemas. Assim, o movimento por Cidades Saudáveis é definido como uma política de saúde a ser implementada. Em 1996, a OMS elegeu o tema Cidades Saudáveis para o Dia Mundial da Saúde, diante da constatação de que milhões de habitantes das cidades dos países em desenvolvimento no mundo vivem em precárias condições de vida e de saúde. Trata-se, de acordo com a instituição, de conclamar os

\footnotetext{
${ }^{4}$ Dentre eles podemos citar: El movimiento de Municipios Saludables en America publicado pela OPS, 1992; Experience with Healthy Municipalities in Latin America. International Conference on healthy and ecological cities, PAHO, 1993.The PAHO Experience with Healthy Municipalities in Latin America, de 1995; WHO Healthy Cities: a programme framework, WHO, 1995; Healthy Cities, publicado pela WHO, 1996; The Healthy Municipalities Movement- A settings approach and strategy for Health Promotion en Latin America and Caribe publicado pela PAHO, 1999.
} 
governos locais e as associações comunitárias para que formem coalizões com o objetivo de melhorar a saúde das cidades e a resolver os problemas ambientais (WHO 1996). O enfoque participativo e intersetorial é reforçado, assim como o estabelecimento de redes nacionais e regionais, visando o intercâmbio de produtos, serviços, tecnologia e informação. O que esses estudos têm procurado enfatizar, portanto, é o papel do governo local, na busca de alternativas para a gestão pública.

Também a mudança nos padrões de mortalidade, mesclando causa mortis por doenças infecciosas e crônico-degenerativas, em que o adoecimento tem estreita relação com as condições socioeconômico-ambientais, constitui-se um dos argumentos da necessidade de controle a partir da melhoria das condições de vida nas cidades. Coloca-se a partir daí, uma série de desafios à saúde pública em termos de definição de planos estratégicos, que possam efetivamente representar um impacto nas condições de vida e saúde da população.

Para DUHL (1986, 1993a, 1993b), a necessidade de se pensar em novos projetos de intervenção nas cidades baseia-se no fato de que nas cidades os problemas estão interrelacionados com outros, e isto traz novos desafios e novas possibilidades de respostas à diversidade e complexidade das cidades. Deparamonos, aqui, com uma das questões apontadas por HANCOCK (1993b), que nos coloca, por um lado, diante da realidade das cidades e das estratégias, e de outro, o reino da utopia, que diz como gostaríamos que fosse o mundo.

Na América Latina, o antecedente próximo do projeto por Cidades Saudáveis foram os chamados SILOS, Sistemas Locais de Saúde, que propunham modificar os tradicionais enfoques de atenção primária, enfatizando a descentralização e a reorientação dos serviços de saúde. A proposta dos SILOS partiu do setor saúde na busca da eqüidade, qualidade, eficiência, com ênfase na participação social. Os SILOS constituíram uma proposta de divisão do trabalho nos sistemas nacionais de saúde, baseada no critério geográfico-populacional. Ambas as estratégias, SILOS e Cidades Saudáveis fortalecem a idéia do "município pela saúde" e se aderem a proposta de um governo local conjuntamente com os cidadãos no desenvolvimento de um plano de Promoção da Saúde. Apesar das semelhanças, a diferença fundamental é que a idéia de Cidades Saudáveis propõe uma agenda política local 
Cidades Saudáveis no Brasil e os processos participativos: os casos de Jundiaí e Maceió

onde os prefeitos adquirem a coordenação da articulação intersetorial e um protagonismo que faltava nos SILOS, necessária à sustentabilidade das ações (PAHO 1997; RUIZ 1998).

O movimento Cidades Saudáveis faz parte de um conjunto de políticas urbanas, implantadas pela ONU, difundidas e implementadas especialmente pela Organização Mundial da Saúde (OMS), que buscam intervenções diretas, influenciando políticos e planejadores locais, assim como o Centro das Nações Unidas para Assentamentos Humanos- Habitat, o Programa das Nações Unidas para o Desenvolvimento- PNUD, o Fundo das Nações Unidas para a Criança - UNICEF (WERNA 1996).

Soma-se, também, aos demais movimentos que ganham destaque neste final de século, como o de Comunidades Solidárias, Cidades Sustentáveis, Cidades Iluminadas, a Agenda 21, entre outros, que vêm ocorrendo, nas diferentes regiões do país e do mundo, e que procuram responder a objetivos que levem em conta o desenvolvimento humano sustentável, a integração social, e a governabilidade.

Os pontos de referência nos quais se baseia este movimento não são novos. A idéia de considerar a cidade ou a comunidade como uma unidade de análise e intervenção já aparece no movimento de saúde pública conduzido por Edwin Chadwick, no século XIX, que já se ocupava com os problemas de saúde em comunidades urbanas, na Inglaterra, cujas cidades cresciam com o aumento de trabalhadores nas fábricas (HANCOCK 1993a).

ROSEN (1994), ao se referir a este período, relata a situação das cidades que iam crescendo subitamente, aglomerando as pessoas em qualquer lugar, de qualquer maneira. O primeiro relatório da Comissão da Saúde das Cidades, proposto por Chadwick, aponta as péssimas condições a que estava submetida a população: alta densidade demográfica, pobreza, crime, insalubridade, alta mortalidade, e apresenta medidas de melhoria. Relacionando pobreza a doenças, e reconhecendo ser a doença importante fator de aumento do número de pobres, concluiu que seria econômico tomar medidas preventivas.

Com o objetivo de disseminar conhecimentos sobre condições urbanas e organizar a opinião pública para apoiar a ação legislativa em favor da saúde pública, 
Cidades Saudáveis no Brasil e os processos participativos: os casos de Jundiaí e Maceió

várias associações foram formadas, sendo a mais significativa a Associação da Saúde das Cidades, fundada em 1844, por Southwood Smith. Ao longo do século XIX, de acordo com ROSEN (1994), os sanitaristas usaram essa abordagem de esclarecimento e formação de opinião pública para atrair a atenção do governo e, assim, chegar à legislação remediadora.

Desde o final do século XIX, a idéia sanitária com um delineamento ambientalista continuou exercendo uma grande influência na definição das políticas públicas dos países desenvolvidos, com ênfase na ação ambiental e prevenção individual. Esta, por sua vez, foi superada pelo advento da era da terapêutica, a partir dos anos de 1930, e vem sendo, até hoje, a prática hegemonicamente valorizada. A partir dos anos de 1970, a maioria dos países do mundo começou a viver a crise do setor saúde, a crise de custos e de paradigmas, para as quais começaram a ser propostas transformações nas políticas de saúde, que enfatizavam a atenção primária à saúde e o desenvolvimento comunitário (ASHTON 1993).

Assistimos, portanto, neste período, a importantes mudanças da saúde pública relacionadas às crises que impulsionaram as transformações históricas da sociedade. Houve uma alteração drástica da estrutura da população, as pessoas passaram a viver mais, em decorrência de descobertas de causas de doenças até então desconhecidas, e de novas terapêuticas, contribuindo para o aumento crescente dos níveis de urbanização.

É também um período em que se evidenciaram as diferenças. Os países ricos tornaram-se cada vez mais ricos, e as desigualdades geradas por um modelo social e econômico excludente aumentaram os níveis de pobreza e carências sociais dos países pobres. A crise no setor saúde dos anos 1970 foi a crise de custos e de paradigmas. Era preciso renovar o interesse pela saúde pública e pelo preventivo. Os maiores contribuintes para a melhora de saúde, diziam os estudiosos, estariam relacionados em menor grau à assistência médica e apoiados em maior medida na importância do desenvolvimento econômico, no incremento da disponibilidade de alimentos, em um ambiente saudável, nas condições de vida e de trabalho.

O informe do governo canadense, de 1974, intitulado Uma nova perspectiva sobre a saúde dos canadenses, conhecido por Informe Lalonde, teve um grande 
Cidades Saudáveis no Brasil e os processos participativos: os casos de Jundiaí e Maceió

efeito no pensamento sanitário, especialmente nos países desenvolvidos, e conduziu de forma indireta o movimento por Cidades Saudáveis. Este informe baseia-se nas constatações do estatístico Mckeown, que analisou a mortalidade por enfermidades infecciosas, na Inglaterra e País de Gales, entre 1840 e 1970, tendo concluído que as doenças tendem a ocorrer nas populações que se desenvolvem alijadas de suas condições ambientais originais. O informe Lalonde assume esses argumentos, aplicando estes princípios à realidade canadense, com definição de estratégias nacionais de saúde e sugerindo que as ações de Promoção da Saúde deveriam se constituir numa importante prioridade (HANCOCK 1993b; ASHTON 1993).

O surgimento da idéia de Cidades Saudáveis no Canadá se deu, em 1978, com a iniciativa do governo local em Toronto de estabelecer um comitê de planejamento, que publicou o informe intitulado "A Saúde Pública nos anos 80", similar ao estabelecido no Informe Lalonde, no final da década de 70. Este informe advoga uma saúde pública com ênfase na dimensão política e social e no desenvolvimento comunitário para constituir Toronto a cidade mais saudável da América do Norte.

Esta idéia, debatida no seminário Healthy Toronto 2000: Beyond Health Care, ocorrido em 1984, seria posteriormente encampada pela Organização Mundial de Saúde - Oficina Européia, que apresenta o conceito no Primeiro Simpósio sobre Cidades Saudáveis em Lisboa, Portugal, em 1986. Como decorrência é elaborada uma proposta para um projeto de Promoção da Saúde, que pretendia desenvolver-se em onze cidades, denominado de Projeto Cidades Saudáveis, com o intuito de unir os setores públicos e privados e as organizações voluntárias para enfrentar os problemas de saúde urbanos. Em 1987, ocorre o segundo simpósio em Dusseldorf, Alemanha, e outras 14 cidades são designadas em 1988. No ano de 1997, 36 cidades européias, localizadas em 23 países eram participantes do Projeto WHO/EURO de Cidades Saudáveis (ASHTON 1993; GOUMANS 1997).

\section{O que é uma cidade saudável?}

A noção de Cidades Saudáveis que vem sendo discutida desde os anos de 1980, especialmente no Canadá e Europa, é muito ampla. Leonard Duhl, psiquiatra e urbanista da Universidade de Berkeley, em artigo publicado em 1986 "The healthy 
Cidades Saudáveis no Brasil e os processos participativos: os casos de Jundiaí e Maceió

city: its function and its future", faz as primeiras aproximações conceituais. A preocupação do autor, nesse momento, não é ainda estabelecer definições, mas tentar delinear as condições essenciais para o estabelecimento de uma cidade "saudável". A primeira exigência é que a cidade dê respostas efetivas para as necessidades de desenvolvimento, para as organizações e para as pessoas; a segunda é que a cidade tenha capacidade para lidar com as crises do sistema e dos seus membros; a terceira condição é que a cidade tenha habilidade para modificar-se e atender às exigências emergentes e, finalmente, o quarto requisito é que a cidade deve capacitar sua população para usufruir de suas vantagens para seu bem-estar, o que não pode ser realizado sem que seja considerada a educação envolvida no processo .

O que o autor busca enfatizar, enfim, é o papel dos cidadãos para lidar com os complexos problemas de saúde e criar uma cidade "saudável", quer dando respostas a questões mais imediatas, quer lidando com questões subjacentes à saúde, que são interconectadas, complexas e multidimensionais: é a interligação, o relacionamento entre as partes e o senso de toda a comunidade que é essencial para fazer uma cidade saudável (DUHL 1986).

A primeira definição descrita para Cidades Saudáveis foi elaborada nesse mesmo ano, 1986, por Hancock e Duhl, que ressaltam a importância histórica do processo de tomada de decisão dos governos locais no estabelecimento de condições para a saúde, para interferir nos determinantes sociais, econômicos e ambientais, por meio de estratégias como planejamento urbano, "empowerment" comunitário e participação da população: uma Cidade Saudável é aquela que está continuamente criando e melhorando o ambiente físico e social, fortalecendo os recursos comunitários que possibilitam às pessoas se apoiarem mutuamente no sentido de desenvolverem seu potencial e melhorarem sua qualidade de vida ( apud HANCOCK 1993a).

\footnotetext{
${ }^{5}$ O movimento de Promoção da Saúde tem tomado como um dos conceito prioritários o de empowerment, que traz na sua raiz o significado de poder, ou ganho de poder para tomar decisões, realizar ações, individual e coletivamente, visando a eficácia política, melhoria da qualidade de vida e justiça social (WALLERSTEIN 1992). A Revista Health Education Quaterly, n²1, publicada em 1994, traz um debate entre os membros da equipe editorial, sobre concepções de empowerment que vêm sendo adotadas em Promoção da Saúde ( BERNESTEIN et al. 1994).
} 
Cidades Saudáveis no Brasil e os processos participativos: os casos de Jundiaí e Maceió

MENDES (1996), foi um dos primeiros autores brasileiros a abordar o tema. Considera o projeto por Cidades Saudáveis como um "projeto estruturante do campo da saúde", em que os atores sociais (governo, organizações da sociedade civil, organizações não governamentais) procuram, por meio da "gestão social", transformar a cidade em um espaço de "produção social da saúde". Desta forma, a saúde é entendida como qualidade de vida e considerada objeto de todas as políticas públicas, dentre estas, as políticas de saúde.

ROUX (1999), é quem faz um interessante exercício para definir o conceito de Cidade Saudável a partir da análise do adjetivo saudável. Saudável, afirma o autor, não faz referência a um estado, porque qualquer que seja o estado de saúde que se alcance, sempre poderá ser aumentado. Uma cidade também não é saudável porque ali se realizam ações que favoreçam a saúde, porque todos os municípios, de uma forma ou de outra, desenvolvem ações de saúde: recolhe-se o lixo, prestam-se serviços assistenciais, controla-se a qualidade dos alimentos. Muitas cidades, também, promovem integração e participação comunitária, por meio de conselhos, e nem por isso podem ser reconhecidos como saudáveis. O que converte a cidade em saudável não é tampouco o fato de que as autoridades e os conjuntos sociais e instituições dediquem esforços para melhorar a qualidade de vida da população, nem que se utilizem racionalmente os recursos locais. Todos esses devem ser denominadores comuns de todos as cidades.

O que converte uma cidade em saudável, para o autor, é a decisão e a vontade política de direcionar todas as políticas sociais, entre elas as políticas de saúde, para uma meta: saúde como qualidade de vida. É decisão e vontade política de combinar recursos e compromissos para alcançá-las. No entanto, somente decisão política não basta. É necessário que se definam as atividades que vão se desenvolver, os aportes e compromissos dos responsáveis por executá-las e as formas de vigiar o cumprimento daquilo que foi decidido.

Do ponto de vista operativo, considera-se que uma cidade começa a ser saudável, quando suas organizações locais e seus cidadãos assumem o compromisso e iniciam o processo de melhorar continuamente as condições de saúde e de bem estar de todos os seus habitantes (ROUX 1999). Destaca-se aqui o aspecto do 
Cidades Saudáveis no Brasil e os processos participativos: os casos de Jundiaí e Maceió

processo de melhoria contínua, muito mais do que um ponto de chegada. Município saudável é uma idéia - força que pode impulsionar os municípios que ainda estão muito distantes de ter indicadores ideais de saúde (PAHO 1997).

A concepção central que permeia tal projeto para MENDES (1996); ROUX (1999) e WESTPHAL (1999), é a de que a saúde é produzida socialmente. Isto implica reconhecer a saúde em sua positividade, muito além de suas implicações negativas, como doença, seqüela e morte. A saúde expressa a qualidade de vida de uma população, expressa um bem estar da sociedade. Produzir saúde socialmente é gerar processos participativos, sociais e institucionais e orientá-los para a elaboração e implementação de políticas públicas saudáveis para superar o quadro de profundas desigualdades. Produzir saúde socialmente é acordar a intervenção coletiva, organizada para remover determinações ambientais, socioeconômicos e culturais de enfermidades, para mudar práticas que atentam contra a saúde. Produzir saúde socialmente significa também intensificar as políticas sociais, que são eminentemente públicas

De acordo com MENDES (1996), a saúde como produto social resulta da ação concertada de governo. O prefeito é o gestor social, o ator político, condutor do desenvolvimento de políticas públicas saudáveis na cidade. Todas as políticas públicas no âmbito da cidade devem ter como critério decisório, a capacidade de modificar a qualidade de vida da população. Nesse sentido, a política de transporte, de educação, de habitação podem ser saudáveis, e o que as introduz na agenda da cidade saudável é o compromisso com a qualidade da vida.

A proposta de Cidade Saudável, portanto, deve ser definida como uma política de governo, na qual deve se envolver o governo como um todo. $\mathrm{O}$ que as experiências brasileiras têm mostrado é que todos os municípios iniciam esses projetos pelo setor da saúde, que tem, no nosso país, uma tradição de luta e um pionerismo na descentralização de ações. É um setor que congrega trabalhadores com um enorme compromisso com as causas sociais. A área de saúde é pioneira, também, no estabelecimento do controle social, por meio da implementação de Conselhos de Saúde em todos os níveis do Sistema Único de Saúde. 
Cidades Saudáveis no Brasil e os processos participativos: os casos de Jundiaí e Maceió

Num projeto por Cidades Saudáveis é preciso, no entanto, avançar e trabalhar a relação e inter-relação da saúde com a educação, com a habitação, com o saneamento, com o transporte, com o lazer, por isso há necessidade da existência de políticas integradas, o que significa mudar. Mudar o processo de trabalho, mudar o planejamento, mudar a forma de gestão (ALMEIDA 1997).

GOUMANS (1997), refere que um dos aspectos mais importantes para o desenvolvimento e sucesso dessas iniciativas é o compromisso político. Entretanto, em estudos sobre Cidades Saudáveis, ou em pesquisas de Promoção da Saúde, este elemento parece não ser muito abordado.

Em uma democracia moderna, como refere a autora, a política é desenvolvida por meio de um processo de interação e negociação entre muitos atores, que definem a política através de suas argumentações, críticas, idéias, negociações e interesses. Não se pode ignorar a presença de grupos de interesse e grupos de pressão que tentam trazer suas questões para a atenção do público e dos formuladores de políticas. Ao fazer oposição, alguns grupos tentam evitar que certas questões recebam atenção demasiada. Políticos do governo representam maior parceria no desenvolvimento político, uma vez que o poder de tomar decisão sobre os propósitos e projetos em políticas públicas é de sua responsabilidade.

GOUMANS (1997, p.61), entende por compromisso político "o interesse expresso por políticos em uma certa questão que adquire significado por meio de palavras elou recursos". Assim, os representantes políticos têm um papel central na tomada de decisão e na construção de agendas, em outras palavras, a probabilidade de uma questão alcançar o status de agenda política aumenta significativamente, quando há interesse governamental na questão.

Conforme KINGDON, citado por GOUMANS (1997), para que uma questão receba apoio é necessário haver um clima político favorável a uma mudança, por exemplo, nos meses anteriores ou posteriores a uma eleição, quando os políticos estão mais abertos a novas questões. Momentos de crise ou questões de interesse pessoal também podem desencadear definições políticas. Entretanto, o que ocorre freqüentemente é que o sistema político existente e as práticas não dão suporte ao desenvolvimento das políticas. $\mathrm{O}$ autor chama a atenção ainda para o fato de que uma 
Cidades Saudáveis no Brasil e os processos participativos: os casos de Jundiaí e Maceió

política pode se esvanecer e não se tornar parte de uma agenda de governo por estar ligada somente a indivíduos e a seus interesses individuais.

Para ALMEIDA (1997, p.78) o compromisso político deve, sobretudo, extrapolar esse "voluntarismo político, isolado, parcial e circunstancial". Trata-se de uma questão política que tem como estratégia principal trabalhar no sentido de sensibilizar os dirigentes e a sociedade para a construção de um processo permanente de aprimoramento democrático e participativo.

GOUMANS (1997) lembra, ainda, a importância do monitoramento permanente das ações políticas. $\mathrm{O}$ acesso a fontes de informação e o monitoramento do ambiente são cruciais para influenciar ou modificar políticas. O que permanece um grande desafio, contudo, é saber se há possibilidade, por exemplo de se avaliar corretamente essa correlação, ou ainda se existe apenas um clima específico determinado que se aplica à todas as situações de mudança política

\section{CIDADES SAUDÁVEIS : AS EXPERIÊNCIAS INTERNACIONAIS}

A amplitude do conceito, o surgimento de uma série de iniciativas isoladas, e mesmo as várias denominações que foram surgindo na última década ao redor do tema, dificultam o trabalho de coleta de dados sobre o assunto. Nos Estados Unidos e Canadá, por exemplo, são desenvolvidos projetos em localidades, denominados Comunidades Saudáveis, que se constituem num dos vários modelos de Promoção da Saúde baseado no suporte comunitário, que visam à melhoria da saúde. Neles, de acordo com FLYNN (1996), são utilizadas uma multiplicidade de abordagens freqüentemente não bem definidas.

A bibliografia a respeito do tema agrupa as experiências que vêm ocorrendo ao redor do mundo, sem, no entanto, documentá-las adequadamente, ficando pouco claros os seus resultados ou se a participação social tem causado algum impacto sobre eles.

Tem havido, de acordo com FLYNN (1996), uma variedade de orientações, com diferentes organizações patrocinando as iniciativas de projetos de Cidades Saudáveis. Até meados de 1995, existiam cerca de 200 projetos em desenvolvimento nos Estados Unidos. Duas iniciativas parecem ter começado este movimento naquele 
Cidades Saudáveis no Brasil e os processos participativos: os casos de Jundiaí e Maceió

país: o Projeto de Indiana, com uma rede de seis cidades (CITYNET Healthy Cities), sob os auspícios da Kellogg Foundation e o Projeto da Califórnia, ambos de 1988.

Este mesmo estudo revela que existem mais de 1000 projetos de Cidades Saudáveis ao redor do mundo, sendo que a maioria encontra-se na Europa e tem tido suporte técnico da Organização Mundial da Saúde. Na Europa, as cidades têm formado redes, e os projetos vêm se desenvolvendo em aproximadamente 650 cidades. Somada às redes nacionais, há a rede de língua francesa, que inclui Cidades Saudáveis na África, Canadá e França; e a rede de língua espanhola congrega as Cidades Saudáveis na Espanha e América Latina.

De acordo com a OPS (1992), a proposta da criação de redes tem por objetivo, tanto o fortalecimento e a difusão do movimento, como a aprendizagem conjunta que permite ações mais efetivas, já que elas podem cooperar no intercâmbio de experiências, oferecer apoio técnico, operativo e solidário. E mais importante: as redes podem conferir maior força ao movimento e representar um importante veículo de integração regional.

A tabela 1, que reproduzimos abaixo, mostra a distribuição de projetos de acordo com as diferentes regiões do mundo, muitos dos quais constituídos em redes.

Esses dados podem sofrer variação, já que muitos projetos podem ter sido interrompidos, e outros terem se iniciado a partir de 1996. Os dados mais recentes, referentes ao Canadá, país onde se iniciam os debates em torno da saúde como qualidade de vida, mostram que o movimento por Cidades Saudáveis supera o total de projetos para todos os países da América.

No Canadá, os projetos vêm se desenvolvendo por meio de 4 redes provinciais: British Columbia, Manitoba, Ontario e Québec, sendo que outras duas, New Brunswick e Saskatchewan, estão tentando formalizar suas redes. A partir de 1996, são descritos pelo trabalho de ST-PIERRE, O’NEILL e DUPRIEZ (1997), 308 municípios e comunidades como integrantes do movimento no Canadá. 
Tabela 1- Globalização de Cidades Saudáveis: a situação regional

\begin{tabular}{|c|c|c|c|c|c|}
\hline $\begin{array}{l}\text { África } \\
(\mathbf{N}=30) *\end{array}$ & $\begin{array}{l}\text { América } \\
(\mathrm{N}=300)^{*}\end{array}$ & $\begin{array}{c}\text { Oriente } \\
\text { Médio } \\
(\mathbf{N}=\mathbf{3 0}) *\end{array}$ & $\begin{array}{c}\text { Europa } \\
(\mathrm{N}=650)^{*}\end{array}$ & $\begin{array}{l}\text { Sudeste } \\
\text { Asiático } \\
(\mathbf{N}=10) *\end{array}$ & $\begin{array}{l}\text { Oeste do } \\
\text { Pacífico } \\
(\mathrm{N}=30)^{*}\end{array}$ \\
\hline África do Sul & Bolívia & Argélia & 23 Cidades & Bangladesh & Austrália \\
\hline Congo & Brasil & Chipre & $\begin{array}{c}36 \text { Projetos } \\
\text { OMS }\end{array}$ & Nepal & China \\
\hline $\begin{array}{l}\text { Costa do } \\
\text { Marfim }\end{array}$ & Canada & Egito & & Tailândia & Japão \\
\hline Ghana & Chile & Iran & & & Malásia \\
\hline Nigéria & Colômbia & Kuwait & & & $\begin{array}{c}\text { Nova } \\
\text { Zelândia }\end{array}$ \\
\hline Senegal & Costa Rica & Oman & & & Vietnã \\
\hline \multirow[t]{4}{*}{ Tanzânia } & Cuba & Paquistão & & & \\
\hline & $\begin{array}{l}\text { Estados } \\
\text { Unidos }\end{array}$ & Tunísia & & & \\
\hline & México & & & & \\
\hline & Venezuela & & & & \\
\hline
\end{tabular}

*Números aproximados - Extraído de Flynn (1996)

O movimento no país, de acordo com POLAND e col.(1998), baseou-se nos princípios da Carta de Ottawa (OMS 1986) e na Estratégia Global de Saúde para Todos no ano 2000 (OMS 1991), e foi oficialmente lançado em 1987 na cidade de Rouyn- Noranda, na província de Québec, sendo que a partir de 1988 houveram vários movimentos com o objetivo de implementação de redes nacionais. As redes provinciais no Canadá têm objetivos e estruturas distintas. Duas delas (British Columbia e Manitoba) não exigem condições de adesão à rede. Três delas têm estrutura formal com um conselho de diretores, que assume diferentes funções em cada uma. As quatro redes publicam um jornal ou outros materiais de divulgação de projetos.

A Rede de Cidades e Comunidades Saudáveis de Québec é a mais estruturada no Canadá. Constitui-se na única rede de língua francesa do país e envolve cerca de 121 municipalidades, $45 \%$ do total população da província. É a única rede que define as condições de adesão à rede. Para tornar-se um membro regular, a municipalidade deve preencher um formulário, acompanhado pela resolução adotada pelo conselho municipal, que inclui assumir: os princípios da filosofia do movimento; o compromisso de definir as diretrizes e as ações na perspectiva da saúde e da qualidade de vida; a criação de um Comitê Intersetorial, incluindo a municipalidade e 
Cidades Saudáveis no Brasil e os processos participativos: os casos de Jundiaí e Maceió

outras organizações; o compromisso de alocar recursos financeiros, humanos e materiais para os projetos, e o compromisso de dividir suas expectativas e experiência com outras cidades da rede.

Após 12 anos de desenvolvimento, as iniciativas Comunidades Saudáveis no Canadá revelam um problema que tem fomentado os debates entre teóricos e técnicos: como avaliar os projetos em desenvolvimento, dado que muitos dos princípios, conceitos e estratégias que envolvem o movimento não estão claramente articulados? POLAND e col.(1998)

Ainda que a experiência canadense tenha servido de "modelo" às experiências desenvolvidas posteriormente na Europa, HANCOCK (1993b), aponta três aspectos que diferenciam as iniciativas canadenses daquelas desenvolvidas sob os auspícios da Organização Mundial da Saúde. O Projeto Canadense foi organizado por três associações nacionais com sede na Associação de Planejamento Urbano, não se constituindo, portanto, em um projeto restrito ao setor da saúde; além disso, não se desenvolve exclusivamente em cidades, estando aberto a comunidades de todos os tamanhos e, por fim, é um projeto bastante aberto à participação comunitária e à inclusão de qualquer comunidade que deseje se unir a ele.

O movimento por Municípios Saudáveis, para a maioria dos países da América Latina, é recente. Foi iniciado pela Organização Pan-Americana de Saúde, após a Declaração de Bogotá (1992) e da Carta de Promoção da Saúde do Caribe (1993), com base na experiência obtida nos projetos desenvolvidos na Europa, Canadá e Estados Unidos. Apesar de suas bases serem universais, a implementação de um município saudável apresenta diferenças significativas.

Nos países ricos, como o Canadá, EUA, Inglaterra, os principais determinantes da má qualidade de vida estão em boa parte solucionados: as pessoas têm acesso à educação, saúde, saneamento básico e renda. Muito embora os indicadores que medem a saúde e a qualidade de vida venham apresentando alteração nas condições de vida das populações em muitos países pobres, especialmente das Américas, reflexo de diversos fatores sociais, ambientais, culturais e tecnológicos, 
Cidades Saudáveis no Brasil e os processos participativos: os casos de Jundiaí e Maceió

assim como maior disponibilidade de serviços ${ }^{6}$, não houve alteração significativa dos diferenciais existentes entre as regiões pobres e ricas do mundo (WALDMAN 2000).

Há de se considerar que os países pobres abrigam $75 \%$ da população mundial e detêm apenas $17 \%$ do produto nacional bruto mundial, $11 \%$ dos gastos em educação, $8 \%$ da indústria e $6 \%$ dos gastos em saúde. São dados que refletem a crise econômica que vivemos, que se reflete no crescimento da pobreza, no crescimento de doenças, na incapacidade de satisfazer as necessidades básicas da população (RICE e RASMUSSON 1993). Por isso, podemos verificar que a implementação da filosofia e das diretrizes do movimento por Cidades Saudáveis nos países em desenvolvimento, nos quais se insere o Brasil, guarda diferenças significativas e está estreitamente relacionada ao contexto social e político desses países.

Em uma análise recente, PAHO (1999) mostra o saldo positivo do movimento por Municípios Saudáveis na América Latina e Caribe, e aponta como o movimento vem se ampliando. Em suas conclusões, relaciona os benefícios que o movimento vem trazendo aos processos de democratização e descentralização do Estado, na medida em que vem promovendo a participação ativa de comunidades e de todos os setores municipais, possibilitando o acesso mais eqüitativo aos serviços de saúde e aos outros serviços sociais. Os estudos revelam, ainda, os inúmeros obstáculos que têm sido enfrentados na implementação de projetos na perspectiva de Municípios Saudáveis, dos quais podemos destacar: a falta de recursos (financeiros e humanos) e de suporte de infra-estrutura; a não participação comunitária; a falta de treinamento, falta de conhecimento em métodos de avaliação, o controle excessivo do setor da saúde, dificuldades no desenvolvimento do trabalho na perspectiva intersetorial, falta de monitoramento dos projetos, entre outros.

No contexto da América Latina, alguns países também vêm adotando a estratégia de criação de redes para seu melhor funcionamento. México, Venezuela e Cuba têm configurado redes para o fortalecimento do movimento e sua difusão. Oferecem apoio técnico e operativo, além de intercâmbio entre as diferentes

\footnotetext{
${ }^{6}$ A modificação da situação de vida e saúde nas Américas e no Brasil durante a última década, assim como a relação das condições de saúde com o desenvolvimento econômico e social na Região, podem ser observadas com detalhes na publicação La salud en las Américas da Organización Panamericana de la Salud, editada em 1998.
} 
Cidades Saudáveis no Brasil e os processos participativos: os casos de Jundiaí e Maceió

localidades. Outros países têm iniciativas de projetos que têm aproximações ideológicas e práticas com o movimento, dentre os quais destacam-se: Bolívia, Colômbia, Equador, Peru, Costa Rica, El Salvador, Guatemala, Honduras, Nicarágua, Panamá, Argentina, Chile, Paraguai, Uruguai, República Dominicana e o Brasil.

A denominação Municípios Saudáveis em vez de Cidades Saudáveis originalmente nascida no contexto canadense e europeu, tem sido adotada dos países da América Latina, em função das diferenças de contexto político, econômico e culturais. Entende-se que os fortes processos de descentralização e o fortalecimento dos municípios, atualmente, em toda a América Latina, bem como o entendimento de que um município envolve, também, a zona rural e que os governos têm competências e obrigações em todo o conjunto do espaço urbano e rural, são diferenciais que dão ao conceito Município uma abrangência e singularidade ao processo (PAHO 1997).

No Brasil, a discussão de denominação desses projetos caminha nessa mesma direção. O termo foi debatido no I Fórum Brasileiro de Municípios Saudáveis ocorrido em Sobral, em 1998. A denominação Cidade Saudável foi defendida porque "cidade" estaria relacionada a polis, local onde as pessoas assumem sua condição de cidadão, e pode, além disso, melhor representar a intensa urbanização que o país vive e os novos problemas de saúde que advém do atual estágio de desenvolvimento dos aglomerados humanos, caracterizados na forma de cidades, da vida urbana. Já o termo Município Saudável foi defendido, por refletir a organização de grande parte dos aglomerados no país, que contém núcleos habitacionais estruturados economicamente na produção rural, localizados em torno de um núcleo principal, de características urbanas mais evidentes. $O$ que se observa é que ambas as denominações são utilizadas, e isso tem relação com o período histórico de aproximação das cidades ao ideário. As cidades que foram sensibilizadas pelo governo canadense a adotar políticas nesta perspectiva utilizam o termo Cidades Saudáveis, enquanto outras, incentivadas por outros órgãos, como a Organização Pan-Americana de Saúde, referem-se ao Município Saudável. Desta forma, manteremos neste trabalho, as designações que são adotadas pelas próprias cidades, que consideraremos como sinônimos. 
Cidades Saudáveis no Brasil e os processos participativos: os casos de Jundiaí e Maceió

\section{PARTICIPAÇÃO NAS POLÍTICAS PÚBLICAS SAUDÁVEIS}

$\mathrm{Na}$ literatura, as justificativas para a inclusão dos países em desenvolvimento no movimento por Cidades Saudáveis vêm sendo relacionadas, fundamentalmente, a três fatores: à situação de crise da política social e o papel do Estado frente a ela; à importância da descentralização das ações e do fortalecimento do poder local; e ao significado da participação no delineamento de políticas públicas (OPS 1992; PAHO 1997; PAHO 1999).

Há um destaque ao papel que os governos devem assumir para enfrentar a crise que tem ampliado as desigualdades e as carências, o que faz com que o Estado tenha um papel decisivo nas transformações do aparato político e na modernização da gestão estatal e pública. Nesse sentido, as políticas públicas deverão ser fruto de interlocução e pactuação dos atores sociais.

A participação de amplos setores sociais é referida como a base de sustentação da cidade saudável, constituindo-se em um elemento central que permeia todos os conceitos que dão suporte à proposta. Neste capítulo, vinculamos a participação a questões fundamentais, tais como: descentralização, intersetorialidade, o papel do Estado, estabelecimento de políticas públicas saudáveis; entendendo que esses conceitos fundamentam e podem contribui para definir estratégias de ação participativas.

\section{DESCENTRALIZAÇÃo, INTERSETORIALIDADE E PARTICIPAÇÃo}

Os documentos que tratam do surgimento do movimento por Cidades Saudáveis nas Américas enfatizam sobremaneira a importância da descentralização. A adoção de processos de descentralização é tida como solução político-institucional para superar o modelo centralizado, próprio de regimes autoritários. A descentralização aparece, nesse sentido, como uma contraposição a uma prática histórica de centralização, especialmente a dos países latino-americanos, onde o Estado centralizado apresenta-se não só ineficiente do ponto de vista funcional, como 
Cidades Saudáveis no Brasil e os processos participativos: os casos de Jundiaí e Maceió

também do ponto de vista democrático, no que se refere à sua adequação para viabilizar e promover a participação e as reformas sociais ${ }^{7}$.

Assim, a descentralização, como transferência do poder decisório a municípios ou entidades e órgãos locais, expressa duas dimensões diferentes, mas complementares: representa a possibilidade de ampliação para o exercício dos direitos dos cidadãos, a autonomia da gestão, a participação cotidiana dos cidadãos e, por outro lado, representa processos de modernização gerencial da gestão pública .

O debate em torno da questão da descentralização não é novo. O movimento de descentralização, como princípio ordenador de reformas do setor público, difunde-se dos países de capitalismo avançado para os subdesenvolvidos a partir da década de 70, e passou a ser considerado como estratégia das políticas sociais no contexto de crise e reestruturação do Estado de Bem-Estar Social, cujo modelo teria ocasionado um enorme movimento de centralização administrativa das políticas sociais, comprometendo a sua eficácia (MELO 1996; JUNQUEIRA 1997).

A idéia de descentralização como dimensão essencial da democratização tornou-se importante nos países da América Latina, especialmente no contexto do fim de ditaduras e de transição democrática vivido por vários países. Na América Latina, a instituição municipal é particularmente frágil, tanto em relação ao poder, quanto em relação às possibilidades de alocação de recursos. A fragilidade das instituições democráticas e a instabilidade do sistema político acabou por gerar, como decorrência, uma concentração de poder no nível central (JACOBI 1992b).

No Brasil, a descentralização esteve intimamente associada à redemocratização, em meio ao aprofundamento da crise econômica (AFFONSO 1996). Este é um processo que ocorreu no contexto de mudanças políticoinstitucionais da década de 80 , particularmente com a retomada das eleições para todos os níveis de governo e a descentralização fiscal da Constituição de 1988. "Diferentemente de outros países, os municípios brasileiros foram declarados entes federativos autônomos, o que implica que o prefeito é autoridade soberana em sua

\footnotetext{
${ }^{7}$ JUNQUEIRA (1996) considera que os conceitos de descentralização e centralização não sejam dicotômicos e excludentes, mas ligados entre si por uma relação dialética, o que pressupõe que a existência de um não exclui a existência do outro.
} 
Cidades Saudáveis no Brasil e os processos participativos: os casos de Jundiaí e Maceió

circunscrição"(ARRETCHE 1999, p.114). O processo de transferência de atribuições contribuiu e potencializou a discussão sobre os alcances da descentralização na sua relação com as demandas de democratização.

Essa discussão, pautada sobretudo em justificativas de ordem política, privilegia os aspectos relacionados ao controle social e à democratização da gestão local. O processo de descentralização ocasiona profundas mudanças e possibilita uma atuação voltada ao desenvolvimento local e tentativas de ruptura com formas tradicionais de ação governamental nos municípios, a exemplo da criação de mecanismos de democracia direta, como o orçamento participativo e outros arranjos que permitem conciliar os múltiplos interesses setoriais relevantes na sociedade local.

Essas e outras experiências de gestão pública brasileiras têm sido muito influenciadas pelas idéias de descentralização e de participação. Nesse sentido, ambos os processos estariam relacionados à possibilidade de maior democratização do nível local de poder. Vários autores têm analisado as políticas locais com base nesses pressupostos (SPOSATI e FALCÃO 1990; JACOBI 1992a; MOTTA 1994; FELICISSÍMO 1994; JACOBI e TEIXEIRA 1996). Apontam a relevância que o processo de descentralização representa, não só como uma opção políticoadministrativa, mas também como um processo de redistribuição de poder político, tendo como desafio o estabelecimento de novas regras que possibilitem o controle mais direto dos cidadãos, enfim, como estímulo a práticas participativas, vinculadas aos processos de democratização política

Embora uma grande parte dos estudos procurem enfatizar as virtudes dos processos de descentralização para a ampliação do exercício dos direitos dos cidadão e para a prática participativa mais ativa, alguns autores têm também apontado as outras interfaces presentes nessa relação.

JUNQUEIRA (1996, p.28), entende que a relação entre descentralização e participação"não é de identidade, mas de sinergia". "A descentralização inscreve-se como uma condição necessária, embora não seja suficiente para desenvolver a participação. De outro lado, a participação é fator de viabilização da descentralização". Para o autor, como existem diferentes formas de distribuição de 
Cidades Saudáveis no Brasil e os processos participativos: os casos de Jundiaí e Maceió

poder na sociedade, "a descentralização não garante automaticamente a participação, podendo em algumas circunstâncias, reiterar as diferenças".

NUNES (1996), embora não discorde da importância da descentralização para a retomada da democratização, questiona se a proximidade do cidadão com o poder local garante que este seja mais factível de ser democratizado e possa servir realmente de palco a uma maior participação. Para o autor, o que ocorre é que as pautas mais concretas são mais facilmente compreendidas pela maioria da população do que os problemas advindos de outras esferas de poder. Mas, "como se vive também em um estado (ou região), em um país e no planeta simultaneamente, a real democratização depende, cada vez mais, das decisões mais universais”. Além disso, “a proximidade do poder é no mínimo ambígua, pois é também o lugar da reprodução do poder discricionário das oligarquias" (NUNES 1996, p.34).

MÉDICI (1994), reitera essa idéia quando afirma que a descentralização permite uma melhor canalização das demandas sociais nas comunidades que já estão mobilizadas na defesa de seus interesses, funcionando como um instrumento de poder. Pode, no entanto, funcionar como instrumento de pressão das comunidades, por parte daqueles que manipulam o poder local.

Outros trabalhos, como o de MOTTA (1994), que tentam ampliar o debate sobre descentralização, participação e distribuição de poder em projetos envolvendo municípios brasileiros, mostram que, em muitos casos, a participação e a descentralização desenvolveram-se até o limite de não alterarem as relações de poder existentes. Importantes conquistas foram alcançadas, já que a participação confere consciência de cidadania e cria um novo sentido nas relações sociais e políticas, no entanto, a população permaneceu submissa a estruturas tradicionais de poder. Com base nesta constatação, MOTTA (1994) infere que: participação e descentralização não se introduzem apenas administrativamente, sendo necessário que se realizem também mudanças nas estruturas políticas, sociais e econômicas, sem as quais participação e descentralização só servirão para acomodar interesses emergentes ou marginalizados.

Não há dúvida de que a descentralização em curso no Brasil apresenta-se como uma idéia força importante. ARRETCHE (1999), em seus estudos sobre o 
Cidades Saudáveis no Brasil e os processos participativos: os casos de Jundiaí e Maceió

processo de descentralização das políticas sociais no país, observa que as áreas de educação fundamental, assistência social, saneamento, saúde e habitação popular são aquelas em que há implantação de programas de descentralização, com transferência de parte das funções de gestão das políticas a estados e municípios. No entanto, conclui que este não é um processo homogêneo e que há uma grande variação referente à extensão do processo de descentralização, entre as diversas políticas e entre os diferentes estados brasileiros. Há municípios com capacidade de assumir a gestão de políticas sociais sem incentivos e, por outro lado, observa-se a existência de um grande número de municípios fracos, de pequeno porte populacional, densidade econômica pouca expressiva, e com significativa dependência de transferências fiscais. Em muitos desses casos a ação do governo estadual ainda se faz necessária.

Portanto, as variações nas formas de descentralização em nível local vão também determinar a direção de uma política local mais autônoma e participativa, com diferentes graus de integração na esfera local e de participação na gestão.

Especificamente na área de saúde, a criação do Sistema Único de Saúde, em 1988, representou avanços institucionais importantes em relação à descentralização. JUNQUEIRA (1996) ao analisar as mudanças ocorridas no setor nas décadas de 1980 e 1990, no Estado de São Paulo, afirma que a descentralização constituiu-se em um significativo fator de mudança, criando novas instâncias de decisão, possibilitando ao Estado transformar-se em prestador de serviços e facilitando as práticas de controle social.

A experiência da área de saúde da cidade de São Paulo (gestão 1989-1992), analisada por COHN (1995b) mostra, contudo, a complexidade do processo de descentralização entre os diversos níveis de um governo municipal. A proposta de descentralização administrativa do setor da saúde, com maior autonomia para os níveis regionais, instituindo canais de participação em todos os níveis, esbarrou na lógica altamente centralizadora da administração pública e na falta de autonomia da própria Secretaria da Saúde. Em conseqüência, as propostas de descentralização com autonomia dos distritos de saúde encontraram na máquina administrativa um enorme obstáculo para se desenvolverem. 
Cidades Saudáveis no Brasil e os processos participativos: os casos de Jundiaí e Maceió

Após duas décadas de experiências descentralizadoras esse processo passa a ser visto com cautela, sobretudo no plano fiscal e tributário, em que se observa uma tendência de reversão da descentralização alcançada e vive-se um momento de retrocesso mais geral, de recentralização. "É como se o processo de descentralização no Brasil sofresse permanentes ataques de forças centralizadoras, independentemente do regime político, autoritário ou democrático” (VIANA 1998, p.29). Em suma, as características do processo de descentralização brasileira "impedem uma expansão mais homogênea do novo papel das cidades e, até mesmo, bloqueiam a construção de uma estratégia mais geral de enfrentamento das questões sociais" (VIANA 1998, p.31).

Estudos recentes, que procuram inovar as gestões públicas municipais, como o de JUNQUEIRA (1997), têm buscado articular às práticas descentralizadoras e participativas um outro elemento, a intersetorialidade. O ponto de partida é a constatação de que, embora muitos municípios busquem concretizar políticas democratizadoras, criando instâncias e instrumentos que permitam a participação do cidadão na gerência de políticas públicas, essas não ultrapassam a lógica das políticas setoriais. Esta lógica, que direciona e estrutura o aparato estatal, não oferece possibilidades de gestões democráticas e inovadoras, uma vez que tende a tratar de forma fragmentada o cidadão e seus problemas, que são parte de um todo complexo. Há necessidade, portanto, de dar respostas integradas aos problemas de saúde, educação, emprego, cultura, moradia, transportes.

"A intersetorialidade tem no campo do fazer significação semelhante à interdisciplinaridade na construção do saber" (MENDES 1996, p.252). Dada a necessidade de se promover e superar a fragmentação do conhecimento humano, herança do projeto iluminista/positivista, em busca de visão e ação mais globalizadas, a interdisciplinaridade procura estabelecer o sentido da unidade na diversidade, promover a superação da visão restrita de mundo e a compreensão da complexidade da realidade (LUCK 1995).

Não é apenas a complexidade dos problemas que impõe a necessidade de ações intersetoriais. Trata-se da busca de "uma unidade do fazer e está associada à vinculação, à reciprocidade e complementariedade na ação humana", sendo que 
Cidades Saudáveis no Brasil e os processos participativos: os casos de Jundiaí e Maceió

aquilo que caracteriza a intersetorialidade é a possibilidade de síntese, dada pela intersubjetividade e o diálogo. "Deste modo, a intersetorialidade não anula a singularidade do fazer setorial pela instituição de uma polivalência impossível; ao contrário reconhece os domínios temáticos, comunicando-os para a construção de uma sintese" (MENDES 1996, p. 252-53).

A intersetorialidade para JUNQUEIRA e INOJOSA (1997), conforme citado por JUNQUEIRA (1997, p. 37), pode ser entendida como "a articulação de saberes e experiências no planejamento, a realização e a avaliação de ações, com o objetivo de alcançar resultados integrados em situações complexas, visando um efeito sinérgico no desenvolvimento social'. Essa dinâmica supõe uma nova forma de gerenciar a cidade, "buscando superar a fragmentação das políticas, considerando o cidadão na sua totalidade. Isto passa pelas relações homem/natureza, homem/homem que determinam a construção social da cidade” (JUNQUEIRA, p. $37)$.

A intersetorialidade nessa perspectiva tem como base um planejamento geral, diferente do modelo tradicional, em que o trabalho é organizado por equipes especializadas para o planejamento, a realização e avaliação de ações e serviços. A estrutura governamental, de acordo com a lógica intersetorial, supõe a articulação de planos, o compartilhamento de informações, e apresenta-se, sobretudo, mais permeável à participação do cidadão, tanto no planejamento, quanto na avaliação (INOJOSA 1998).

GOUMANS (1997), ao analisar os projetos Cidades Saudáveis europeus, conclui que, embora a ação intersetorial se coloque como uma exigência, a retórica parece ter sido mais desenvolvida que a prática. De acordo com a autora, a intersetorialidade pode ocorrer em diferentes níveis e entre diferentes esferas. A retórica da colaboração defende que os atores são iguais, isto é, têm igual poder de colaborar entre si, no entanto, mais freqüentemente os atores têm graus bastante variados de poder, devido às iniqüidades estruturais subjacentes, tais como acesso ao dinheiro, conhecimento ou poder.

As experiências em curso sobre Cidades Saudáveis na América Latina, pouco documentadas, não oferecem subsídios para se proceder a uma análise do 
Cidades Saudáveis no Brasil e os processos participativos: os casos de Jundiaí e Maceió

impacto das mudanças político-culturais que envolvem as práticas coletivas e intersetoriais, especialmente aquelas com capacidade de fortalecer o potencial dos cidadãos no processo decisório, dentro de uma lógica não cooptativa.

No Brasil, algumas iniciativas têm sido implementadas por municípios e se inscrevem na tentativa de introduzir novas formas de gestão e controle social, como orçamentos participativos, programas de geração de emprego e renda. No entanto, como bem aponta VIANA (1998), "barreiras burocráticas e corporativas” impedem

o pleno desenvolvimento dessas experiências intersetoriais, que ficam restritas a poucos municípios, constituindo-se em experiências temporárias, logo, passíveis de serem interrompidas.

\section{IMPLEMENTAÇÃO DE POLÍTICAS PÚBLICAS SAUDÁVEIS: O PAPEL DO ESTADO E DA SOCIEDADE CIVIL}

A formulação e implementação de políticas públicas saudáveis é uma das diretrizes e um dos componentes centrais das estratégias de Promoção da Saúde. Esta expressão passou a designar a idéia de que muito do que influi na saúde se encontra fora do campo das intervenções médicas ou da saúde pública tradicionais (LALONDE 1974; LEVIN e ZIGLIO 1996).

Para GOUMANS (1997), o conceito de políticas públicas saudáveis ainda permanece bastante vago e abstrato. Ao analisar os conceitos que estão presentes no ideário por Cidades Saudáveis nos projetos europeus, conclui que a intersetorialidade e participação da comunidade têm recebido maior atenção em pesquisas, e que temas como o compromisso político e as políticas públicas saudáveis têm sido desenvolvidos e estimulados por um número bastante limitado de pesquisadores. Para ela, isso pode ser explicado, por um lado, pela complexidade dos temas e a escassez de estudos de caso que estão disponíveis para a pesquisa. Por outro, que a intersetorialidade e a participação comunitária apelam para o senso comum dos indivíduos em um grau mais significativo do que as idéias do compromisso político e políticas públicas saudáveis.

Há duas abordagens de políticas de saúde prevalecentes na Promoção da Saúde, de acordo com a autora. Na primeira abordagem, uma política de saúde envolve fazer investimentos em setores para tratar de um problema específico de 
Cidades Saudáveis no Brasil e os processos participativos: os casos de Jundiaí e Maceió

saúde. Ela trata da promoção e prevenção no campo da saúde e solicita participação de outros setores. Tal política é o que estimula os definidores de políticas e planejadores a perceber os efeitos de suas decisões sobre a saúde. Além de governos e profissionais de saúde, muitas outras pessoas devem estar envolvidas na elaboração desse tipo de política. Esses atores podem representar, por exemplo, os setores do bem estar social, das indústrias, da educação, da economia e comércio, da mídia e das comunidades.

Uma política de saúde pode também significar que todos os setores públicos avaliem suas políticas entre outras coisas com base nos possíveis efeitos sobre a saúde. Este conceito nos leva à segunda abordagem, que MILIO citado por GOUMANS (1997), denominou de política pública saudável. Uma política pública saudável é caracterizada por uma preocupação explícita com saúde e eqüidade promovidas por várias áreas e com uma responsabilidade conjunta pelo impacto em saúde.

A principal diferença em relação à primeira abordagem é que o ponto de partida para essa política não é um problema de saúde, mas pode ser qualquer questão, por exemplo, de economia, de tráfego, ou de segurança (GOUMANS 1997).

Nessa visão, é fundamental integrar as preocupações de saúde no processo de tomada de decisão de setores como o ambiental, o do trabalho, o do transporte, o da habitação e outros, que têm repercussões nas condições de saúde de uma população (LABONTÉ 1992).

A noção de políticas públicas saudáveis, nesse sentido, está estreitamente vinculada à ação intersetorial, à cooperação interorganizacional, à participação social. A criação de um conjunto de mecanismos, de caráter político, promovendo a integração da ação pública, com participação na implementação das políticas sociais integradas, constitui para BUSS (1996), uma estratégia de operar as políticas públicas saudáveis. Assim, é necessário colocar a saúde de forma positiva na agenda de todos os setores e em todos os níveis de governo. Este compromisso político de situar a saúde no topo da agenda pública promovendo-a de setor da administração à critério de governo, somado ao compromisso técnico de enfatizar como foco de intervenção os fatores determinantes do processo saúde-doença é, no entender de 
Cidades Saudáveis no Brasil e os processos participativos: os casos de Jundiaí e Maceió

CARVALHO (1998), o duplo compromisso que envolve a idéia moderna de políticas públicas saudáveis.

Para FARRANT citado por GOUMANS (1997), o desenvolvimento de políticas públicas saudáveis exige uma maior transformação dos processos e estruturas políticas e implica uma mudança fundamental na distribuição de recursos e poder na sociedade. Para o autor, os limites e as contradições ao perseguir tal objetivo no contexto político e econômico do século $\mathrm{XX}$ não podem ser superestimados. O rápido crescimento do movimento por Cidades Saudáveis é uma indicação clara da necessidade de uma mudança radical da saúde pública. Cidade Saudável, nesse sentido, abre caminho para o desenvolvimento de políticas públicas saudáveis.

As políticas públicas saudáveis intervêm não apenas para diminuir o risco de doenças, prolongar a vida, mas também, nos obstáculos à vida com qualidade, com bem-estar, com autonomia. Este entendimento implica uma abordagem mais complexa, que supõe, além da concepção ampla do processo saúde-doença e de seus determinantes, um entendimento do papel que o Estado e a política pública devem desempenhar na vida contemporânea (CARVALHO 1998).

Nesta concepção, tomando como referência a realidade dos países em desenvolvimento, qual seria a função do Estado, ou seja, como captar demandas e necessidades sociais para transformá-las em direitos, em sociedades marcadas por profundas desigualdades sociais?

Esta não é uma questão fácil de ser equacionada, especialmente quando se leva em conta que na história do desenvolvimento econômico e social brasileiro, a relação do Estado com a sociedade civil frente ao estabelecimento de políticas públicas, sempre foi cercada de conflitos.

O modelo de acumulação brasileiro que foi se fortalecendo sobretudo a partir da década de 30, com a implementação de políticas de industrialização induzidas pelo Estado, traz consigo profundas mudanças sociais, de urbanização da população, e vai gerando nas décadas seguintes um processo de desenvolvimento econômico desigual e um conjunto de políticas sociais voltadas à reprodução da força de trabalho urbana. A forma tendencial desse processo de acumulação gerou, nos anos 
Cidades Saudáveis no Brasil e os processos participativos: os casos de Jundiaí e Maceió

de 1960 e 1970, o crescimento econômico do país, contra um processo de pauperização da maioria dos trabalhadores. O período pós-64, do ponto de vista político-institucional simbolizou a força autoritária e repressiva, e do ponto de vista econômico, teve como base investimentos no setor de bens de capital, grande presença do capital financeiro e crescentes empréstimos internacionais. $\mathrm{O}$ caráter centralizado das políticas sociais no âmbito federal se agudizou, bem como consolidou a entrada do setor privado na esfera pública (COSTA 1988; COHN 1995a).

A intervenção do Estado, nesse período, na resolução das carências, pautou-se por uma ênfase nas características autoritárias, sem ser acompanhada pela participação da sociedade, mas se definiu, "na formulação de políticas que refletem a seletividade específica do sistema político” (JACOBI 1989, p.143).

O agravo das condições de sobrevivência, aliado à luta pela redemocratização no país, fez com que a partir dos anos de 1970 se configurasse a emergência de novas forças sociais, representadas pelos movimentos sociais que reivindicavam bens e serviços inexistentes ou insuficientes. A ocupação do cenário político por novos atores sociais fez emergir ações coletivas em todas as áreas sociais. Em princípio, os movimentos organizados atuaram como força popular independente do Estado, já que este era visto como inimigo dos movimentos progressistas, depois como interlocutores do Estado, já que este estava se democratizando e buscando mudar sua face de repressão. Esta mudança para CARDOSO (1983, p. 236) significa que $o$ "Estado reconhece as associações populares como interlocutores e se torna mais flexível diante de suas demandas, porém as finalidades sociais e o controle de sua aplicação escapam totalmente ao âmbito da ação dos movimentos sociais".

É certo que os movimentos se inseriram em instâncias institucionalizadas, como Conselhos previstos pela maioria dos planos e projetos governamentais, alterando a natureza da relação sociedade civil organizada e Estado, de confronto, para de negociação. O Estado passou a reconhecer seus interlocutores, e se tornou mais flexível às suas demandas, embora a lógica de sua intervenção, pautada na concepção de centralidade e auto-sustentação financeira, não tenha sido alterada significativamente (JACOBI 1989; GOHN 1997). 
Cidades Saudáveis no Brasil e os processos participativos: os casos de Jundiaí e Maceió

As transformações políticas no cenário internacional nos anos de 1990 provocaram uma série de mudanças sociais, que enfatizam outras questões. Segundo COHN (1995a), assiste-se, hoje, a um embate entre duas correntes. Por um lado, a idéia defendida pela corrente neoliberal, que advoga um Estado mínimo necessário ao funcionamento do mercado e totalmente dominado pelas forças e interesses do capitalismo global. Tendo o mercado como principal agente regulador da ordem econômica, dissocia o Estado de suas obrigações em relação às questões sociais. Mínimo, como salienta CACCIA BAVA (1999), apenas quando se refere à defesa dos interesses coletivos, mas que atua fortemente em defesa do capital financeiro. Por outro lado, uma concepção que defende a existência de um Estado democrático forte, com capacidade de intervenção e possibilidade de encaminhar as reformas necessárias ao mercado e ao próprio Estado.

Para SOUSA SANTOS (1998), essas duas correntes têm, na verdade, relação com as profundas mudanças do papel do Estado e com o paradigma reformista que vem se estabelecendo nos últimos 50 anos. $\mathrm{O}$ movimento que dá origem à reforma do Estado apresenta duas principais fases: a primeira delas parte da idéia de que o Estado é ineficaz, parasitário e predador, e, portanto, "irreformável”, por isso, a única reforma possível e legítima seria reduzir o Estado ao mínimo. A segunda idéia sustenta que a reforma do Estado deva ser realizada pelo próprio Estado. No entanto, esta força estatal deve ser diferente daquela que se traduziu no Estado-providência e no Estado desenvolvimentista, em que o Estado intervém na ordem econômica e social em grandes proporções. Ou seja, parte-se do suposto de que a questão do Estado não se resolve pela quantidade de Estado, mas pela construção de outra qualidade de Estado.

Esta é a fase em que nos encontramos, de acordo com o autor. Ela se assenta em dois pilares, na reforma do sistema jurídico e judicial; e no papel desempenhado pelo terceiro setor ${ }^{8}$ na reforma do Estado.

\footnotetext{
${ }^{8} \mathrm{O}$ terceiro setor é um conceito abrangente e difuso. Essa designação. têm recebido diversos sentidos, de acordo com contextos políticos e históricos. Para SOUSA SANTOS (1998), são organizações sociais não estatais que não visam lucros. Nos chamados países de Terceiro Mundo são denominadas de Organizações Não Governamentais. Para CACCIA BAVA (1999), o conceito de terceiro setor é ainda provisório, uma vez que se trata de uma experimentação social de reunir instituições muito
} 
Cidades Saudáveis no Brasil e os processos participativos: os casos de Jundiaí e Maceió

Nesta perspectiva, caberia ao Estado não só desempenhar suas funções econômicas, mas também implementar políticas públicas que incorporem a cidadania: "não se trata, pois de desmantelar o Estado, mas de reconstruí-lo, capacitando-o de inteligência para captar demandas e necessidades sociais, transformando estas em direitos" (COHN 1995a, p.239). Nesta discussão, alguns temas podem ser destacados, como a necessidade de reconstrução de um Estado forte e socialmente legitimado, com responsabilidade social, democrático, que busque redefinir radicalmente as relações Estado e sociedade civil, que enfrente as questões provocadas pela desigualdade social e que encaminhe soluções socialmente significativas no campo da educação, moradia, emprego, saúde.

Há de se ressaltar a importância da articulação e reforma simultânea do terceiro setor que emerge com força no espaço público não estatal, mas sujeito, conforme aponta SOUSA SANTOS (1998), aos mesmos vícios atribuídos ao Estado. Nesse sentido, é relevante determinar o papel do terceiro setor nas políticas públicas, que dependem tanto do próprio terceiro setor, como do Estado. Na formulação de políticas públicas, de acordo com o autor, tal papel poderia estar determinado, basicamente, por três tipos de relação: o terceiro setor como instrumento do Estado; o terceiro setor como amplificador de programas estatais e, finalmente, o terceiro setor como parceiro nas estruturas de poder e de coordenação.

CACCIA BAVA (1999), no entanto, ao analisar o percurso do terceiro setor no Brasil infere que o sucesso dessa "experimentação social depende, sobretudo, da democratização das instituições que regulam a vida social e da redefinição de seus objetivos em prol da eqüidade e da justiça social, de uma nova relação do Estado com a sociedade civil” (CACCIA BAVA 1999, p.8).

Trabalhando com essa perspectiva da garantia de novas relações entre a sociedade civil e o Estado, GIDDENS (1999), propõe que as políticas devam ter novas características, visando o estabelecimento de uma parceria crescente entre as partes. As parcerias entre governo e instituições da sociedade civil, com a redefinição de papéis de ambos, para GIDDENS (1999), deveriam ser estabelecidas visando 
Cidades Saudáveis no Brasil e os processos participativos: os casos de Jundiaí e Maceió

facilitar a ação de ambos. Nesse sentido, o autor defende a "renovação comunitária" por meio de iniciativas locais, com uma sociedade marcada por elevados níveis de auto-organização, cada vez mais "reflexiva", e onde o governo tem um papel mais ou menos decisivo, dependendo do contexto. Para GIDDENS, o Estado, apesar do poder que tem, de dominar e num ponto extremo até esmagar a sociedade civil, tem também um papel de mediador em relação aos conflitos existentes na sociedade civil e uma contribuição na "renovação da cultura cívica", na promoção de uma sociedade civil ativa. "As políticas de renovação comunitária não devem ignorar a esfera pública. Uma esfera pública aberta é tão importante em nível local, quanto em nível nacional, e essa é uma das maneiras pelas quais a democratização se liga diretamente ao desenvolvimento comunitário"(GIDDENS 1999, p. 95).

No Brasil, os estudos também destacam a mudança de papéis do Estado e da sociedade civil nos anos de 1990 visando a transformação social, principalmente frente às alterações político-institucionais que vem se dando. Essas teorias surgem como tentativas de respostas às exigências da realidade. Para PAOLI (1995), é certo que nos anos de 1990, período de dúvidas e incertezas com relação às perspectivas futuras na sociedade brasileira, os movimentos sociais deslocam-se quase que inteiramente para a esfera de sua interação com os governos. Esta participação em experiências de negociação com os governos locais em torno das políticas públicas acaba produzindo uma nova formulação no terreno da autonomia dos movimentos versus participação nas esferas públicas. Há os que defendem que as negociações com os poderes públicos acabam com a autonomia dos movimentos, e outros, que pensam que esta relação é um desafio, no sentido dos movimentos atuarem mantendo a independência, mesmo dialogando, negociando na direção de uma "democracia real".

Nesse sentido, têm surgido, segundo esta autora, duas formas de entender a problemática: a primeira é a de que os movimentos tendem a ser cooptados por governos locais, e não assumem sua identidade nos atuais conflitos e negociações com os poderes públicos, participando somente dos bastidores de um processo que possibilitaria instituir novos padrões de cidadania. $\mathrm{O}$ descrédito diz respeito à fragmentação e ao caráter pontual das negociações, à participação de agentes externos aos movimentos e, fundamentalmente, a crítica se refere à 
Cidades Saudáveis no Brasil e os processos participativos: os casos de Jundiaí e Maceió

representatividade política dos movimentos, quando estes participam de negociações, ou quando dividem a responsabilidade em gerir recursos públicos. A segunda, ao contrário, vê na negociação um espaço importante para instituir novos padrões de cidadania. Os que têm perseguido esse caminho, salienta PAOLI (1995), têm apontado para o fato de os movimentos terem saído da esfera reivindicativa e passado a se expressar na política, em novos modos de negociação, a exemplo das câmaras setoriais de setores produtivos ${ }^{9}$; co-gestão de programas governamentais; mobilizações de atores sociais em relação às leis das cidades, etc.

Assim, a participação enquanto discurso incorporado em programas e projetos governamentais passa a ser entendida como um processo, que muitas vezes, sustenta uma proposta de democratização. No entanto, este processo não é linear. VERAS e col. (1994), também apontam para a contradição existente na participação dos cidadãos na gestão e na condução do poder público, que depende fundamentalmente dos processos políticos em curso. Se a gestão for autoritária a participação pode ser usada para legitimar ou cooptar, na busca de um consenso para aceitação de decisões políticas. Se os compromissos forem democráticos, podem ser criadas condições para a ruptura com essa lógica, e a participação pode emergir como fundamento da ação política.

Mesmo que se reconheça que os conflitos e dificuldades podem ser restritivos aos processos de mudança social, não se pode desconsiderar que o momento atual parece propício para a proposição de novas práticas e criação de espaços de integração entre diversos atores. Nesse sentido, na implementação de políticas de Promoção da Saúde, dentre as quais se inserem as propostas por Cidades Saudáveis, apoiadas e impulsionadas por atores territoriais, podem promover espaços políticos negociados visando impulsionar o desenvolvimento local, incidindo positivamente na gestão do espaço público local. Isto implica estabelecer, contudo, compromissos de interesse público, redefinir o papel do Estado e da sociedade frente ao estabelecimento de políticas sociais, definir fóruns participativos e pactuados que sejam expressivos da diversidade de interesses e necessidades sociais.

\footnotetext{
${ }^{9}$ Este aspecto é analisado no trabalho de Guimarães, IGR. Câmaras setoriais- histórico, constituição e perspectivas. São Paulo em perspectiva. Revista da Fundação SEADE, 8(3):15-22, 1994.
} 


\section{PARTICIPAÇÃo NOS PROJETOS CIDAdes SAUdÁVEIS}

Já há algum tempo, a temática da participação vem se incorporando em programas da área de saúde, e tem sofrido freqüentes questionamentos acerca da forma como vem se dando (WESTPHAL 1992, ADORNO 1992, VALLA e STOTZ 1993, BÓGUS 1997).

Estas iniciativas remontam ao período pós II Guerra Mundial, quando eram propostos projetos por organizações internacionais que não tinham outro objetivo senão a integração da população ao processo de desenvolvimento econômico e social capitalista, que necessitava se aperfeiçoar para conquistar bases de legitimidade política (WESTPHAL 1992; ADORNO 1992). É nesse sentido que ADORNO (1992) relaciona o próprio termo "participação em saúde" nos anos de 1960, à idéia de "cooptação institucional".

Enquanto elemento essencial na estratégia de atenção primária à saúde, a participação da população na gestão da saúde tem merecido destaque, principalmente a partir da Declaração de Alma-Ata de 1978, tendo sido ratificada pelos governos membros da OMS e OPAS. Entretanto, a própria OPAS, em documento recente, após avaliação e revisão de experiências participativas nos países latino americanos, reconhece que "em grande parte as ações comunitárias, as que com freqüência se chamam de participação comunitária, foram na realidade ações dirigidas pelo setor saúde e em muitos casos foi uma franca manipulação da comunidade para estender a cobertura e aproveitar melhor os serviços de saúde" (OPS 1995, p.3).

No Brasil a participação em saúde intensifica-se nos anos de 1980 e tem relação com o contexto da progressiva liberalização do regime, e com a consolidação de espaços institucionais mais democráticos deste período, onde instaura-se, no país, o que GOHN (1997), chama de a "era da participação”.

Na tentativa de entender este período, que culmina, na área de saúde, com o movimento da chamada Reforma Sanitária Brasileira, que prevê a participação nos projetos de racionalização e reforma do setor, incluindo a política de descentralização dos serviços de saúde e a participação na ampliação da 
Cidades Saudáveis no Brasil e os processos participativos: os casos de Jundiaí e Maceió

democratização da gestão local, autores como COSTA (1989), WESTPHAL (1992) e

BÓGUS (1997), lançam mão de referências relacionadas aos movimentos sociais urbanos ${ }^{10}$ e aos chamados novos movimentos sociais ${ }^{11}$, entendendo que os movimentos sociais na área de saúde aproximam-se destas concepções.

O sentido de buscar esses referenciais oriundos das reflexões conceituais no campo das ciências sociais, surge da análise de que o problema da democratização das políticas sociais não é restrito ao setor de saúde, mas relaciona-se ao processo de transição democrática brasileiro, que nos interroga a respeito das relações entre o Estado e as classes populares (COSTA 1989).

A inserção dos movimentos que lutam por melhor qualidade de vida no espaço político instituído tem, no país, estreita vinculação com o processo constituinte. A Constituição de 1988 definiu direitos do cidadão e assegurou vários mecanismos de participação popular como nunca antes presenciados na sociedade brasileira, enunciando uma democracia baseada em uma cidadania participativa.

A participação institucionalizada compareceu intensamente no discurso da área de saúde e acirrou os debates sobre o reconhecimento do controle social por parte do Estado. Os movimentos sociais e alguns estudiosos colocavam em dúvida sobretudo a prática autoritária dos governos, que vinha permitindo a política do

\footnotetext{
${ }^{10}$ COSTA (1989), utiliza esta conceituação no sentido estrito, excluindo, portanto, o uso genérico que se faz do termo para denominar todas as formas de luta social, como as lutas sindicais, camponesas. Os trabalhos teóricos a respeito dos movimentos sociais urbanos, no Brasil, tiveram filiação de estudiosos europeus, Jordi Borja e Manuel Castells, que tomam os movimentos urbanos como práticas contraditórias que convertem a ordem estabelecida a partir das contradições específicas da problemática urbana, tendo como pano de fundo de suas análises as manifestações que ocorreram em sociedades desenvolvidas. KOWARICK (1988), não se furta de criticar os pesquisadores brasileiros que importaram seus conceitos para uma urbanização capitalista inteiramente diversa daquela que caracteriza os países centrais.

${ }^{11}$ Há várias interpretações para designar os "novos" movimentos sociais. Para GOHN (1997), eles buscam se contrapor às manifestações tradicionais de luta social, expressos no modelo clássico das associações amigos de bairro ou associação de moradores. Para o sociólogo Alain Toraine, o final dos anos de 1970 marca a morte do "velho" movimento social, o movimento operário, e a emergência dos "novos" movimentos sociais: de gênero, de pacifistas, ecológicos, nacionalistas (DOIMO 1995). No Brasil, não podemos nos esquecer, no entanto, do caráter renovado das lutas operárias, no final desta mesma década: o "novo sindicalismo". SLATER (1989), ao analisar os movimentos sociais na América Latina, de acordo com as reflexões realizadas por Habermas nos países de Primeiro Mundo, conclui que não podemos caracterizá-los como "novos", já que se encontram num estágio intermediário com reivindicações voltadas a questões referentes à produção e distribuição de bens e serviços e outras relacionadas com o modo de vida das pessoas.
} 
Cidades Saudáveis no Brasil e os processos participativos: os casos de Jundiaí e Maceió

clientelismo que historicamente prevalecia sobre a política do direito (WESTPHAL 1992). No período que precede a $8^{\text {a }}$ Conferência Nacional de Saúde, de 1986, e a Constituição Brasileira, de 1988, a idéia de participação é baseada na institucionalização das relações Estado/sociedade civil e ganha um significado positivo: se, por um lado, essa participação legitima a política do Estado, por outro, abre um canal para que a população dispute o controle e a destinação da verba pública e esteja presente em vários níveis da administração pública (VALLA 1993).

Desta forma, o clima de otimismo que tomou conta do setor saúde, imediatamente após a enunciação de direitos constitucionais, foi reforçado com a implantação de experiências institucionais centradas na participação popular, na descentralização dos serviços de saúde, como aquelas referentes à implantação de conselhos gestores tripartites (população/trabalhadores da saúde e administradores de saúde), para gerenciar os serviços de saúde em todas as instâncias do Sistema Único de Saúde, do nível local ao federal.

No entanto, o fato é que muitos direitos anunciados constitucionalmente não foram regulamentados. É fato, também, que houve um certo desencantamento com o espaço institucional da política e queda no ritmo e extensão das mobilizações, o que fez com que alguns autores decretassem a morte dos movimentos sociais.

Nesse clima de mudanças, são apontadas as contradições e conflitos que permeiam as experiências participativas vividas no campo da saúde. As tendências enumeradas por PAOLI (1995), expressam-se nas interpretações de estudos, sobretudo nos de gestão participativa de saúde (JACOBI 1992a; VALLA 1993; COHN e col. 1993; WESTPHAL 1995), em que se procura entender como os movimentos negociam com o Estado, como constróem alianças políticas e qual o papel que desempenham na cena política. ${ }^{12}$

Se, por um lado, são apontados aspectos inovadores na relação Estado/sociedade civil, e há um consenso de que a participação tem trazido avanços

\footnotetext{
${ }^{12}$ Embora tenham sido menos estudados, os processo de acordos coletivos da área de saúde do trabalhador têm ocorrido nos últimos anos. Pressupõem negociações entre trabalhadores, empresários e Estado, tendo por objetivo a melhoria das condições de vida, saúde e trabalho BONCIANI e col (1996).
} 
Cidades Saudáveis no Brasil e os processos participativos: os casos de Jundiaí e Maceió

importantes, especialmente no sentido de se garantir uma relação mais democrática nos serviços de saúde, com a possibilidade concreta de criar canais de exercício de cidadania, por outro, ressalta-se a preocupação em tornar o processo participativo uma "panacéia", considerado como solução a todos os problemas da população excluída do acesso aos serviços públicos de saúde e dos processos de negociação e decisão de políticas públicas que podem interferir na qualidade de vida (JACOBI 1992a; JACOBI 1992b; COHN e col. 1993).

Nesse sentido, uma série de limites e problemas são enumerados, os quais estão mais comumente relacionados à manutenção da independência e autonomia e ao controle popular numa situação de participação institucionalizada; ao fato do espaço institucional estar marcado por uma cultura tutelar, clientelista e populista; à existência de estruturas tradicionais e autoritárias; à desigualdade de conhecimentos; às dificuldades de acesso às informações.

O desafio que se coloca é como compreender a complexidade da problemática da participação nos projetos Cidades Saudáveis e como caracterizá-la, uma vez que isto pode auxiliar no entendimento sobre como iniciativas locais podem contribuir no enfrentamento dos problemas complexos das cidades. A ênfase na ação de grupos e das organizações sociais coloca a necessidade de reorientar os fatores que afetam o direcionamento das políticas públicas locais, a destinação de recursos, a definição de prioridades, a identificação de soluções viáveis e de atividades para melhorar as condições de saúde que afetam a qualidade de vida da população.

A relevância que os processos participativos assumem nos projetos Cidades Saudáveis merece destaque, porém, poucos estudos têm aprofundado o tema. Observa-se que nos países em desenvolvimento, o enfoque de Cidades Saudáveis concentra-se, como vimos, na democratização do processo de gestão das políticas, seja por meio do fortalecimento do poder local, seja por meio do fortalecimento da participação, como também através da implementação de projetos intersetoriais.

Os enfoques observados, na teoria e na prática da participação da população no setor saúde nas décadas anteriores, devem ser ampliados no sentido de se 
Cidades Saudáveis no Brasil e os processos participativos: os casos de Jundiaí e Maceió

aproximar dos chamados modelos de co-gestões ${ }^{13}$ (OPS 1995). Estes modelos são considerados capazes de potencializar a integração e maximizar seus efeitos por meio do manejo e resolução dos conflitos via negociação. Reconhece-se que facilitar a participação social nas decisões relevantes, necessariamente, afeta as relações de poder e isto gera situações de conflito. Nesse contexto, promove-se o diálogo como meio para a resolução desses conflitos (OPS1995). Nesta visão, encontra-se implícita uma atenção cada vez mais importante nas condutas sociais e na ação de grupos e organizações, em contrapartida à ênfase em condutas individuais isoladas.

O conceito de participação, tal como é incorporado nos projetos Cidades Saudáveis, é aquele que vem sendo discutido desde desenvolvimento dos Sistemas Locais de Saúde, denominado de "participação social”, que se amplia em relação aos conceitos anteriormente incorporados no setor da saúde, de "participação comunitária", envolvendo, além das organizações sociais, um maior número de atores, fortalecendo a relação comunidade-instituição e a deliberação participativa. Assim, a participação social é conceitualizada como: "um processo social inerente à saúde e desenvolvimento, através do qual os grupos comunitários, organizações, instituições, setores e atores sociais de todos os níveis, intervêm na identificação de necessidades ou problemas de saúde e se unem para desenhar e propor na prática as soluções ou ações a seguir” (OPS 1999a, p.23).

A idéia de implementação de políticas públicas saudáveis segue fundamentalmente esta premissa. Como políticas públicas não exclusivas do aparelho estatal, devem ser elaboradas e pactuadas em fóruns participativos, sujeitas a negociações e a lutas políticas em diversas arenas e cenários, representando uma

13 A OPS utiliza o termo co-gestão nos documentos referentes às Cidades Saudáveis como um processo de intervenção conjunta das instituições de saúde, do pessoal de saúde, dos cidadãos, da administração municipal, e dos diferentes setores da sociedade. Para BOBBIO (1986), o conceito de co-gestão tem um significado diferente. Diz respeito a uma forma de encontro entre capital e trabalho realizado apenas na empresa, quando os trabalhadores, por meio dos sindicatos, estão dispostos a desempenhar um papel mais cooperativo que conflitante. Para o autor, co-gestão e participação mantêm ligações diretas, uma vez que o processo de co-gestão pode induzir os trabalhadores ao desejo de participar nos resultados da empresa que ajudam a gerir e, por outro lado, trabalhadores que participam nos resultados econômicos da empresa se sentem movidos a reivindicar o controle e coresponsabilidade em sua gestão. Por isso, decidimos utilizar neste trabalho outros termos como gestão conjunta, gestão compartilhada, quando nos referirmos aos processos de gestão participativos. 
Cidades Saudáveis no Brasil e os processos participativos: os casos de Jundiaí e Maceió

redistribuição de direitos e responsabilidades entre Estado e sociedade civil (CARVALHO 1998).

No desenvolvimento do processo negocial, LABONTÉ (1992), aponta para o fato de que a participação social nas políticas públicas saudáveis não é apenas parte de um direito político ou democrático, mas também significa contribuir para o fortalecimento e o desenvolvimento das comunidades. Há de se construir a participação autêntica, diz o autor, ao criticar, de um lado, a manipulação por parte de instituições do Estado e, de outro, o controle absoluto por parte da comunidade. Enumera algumas características que são fundamentais nesse processo: relações negociadas entre os associados; abertura para denominar os problemas adequadamente, em que os grupos mais fortes não roubam a agenda dos menos fortes, autoridade compartilhada na tomada de decisões; identificação e compromisso de todas as pessoas e grupos envolvidos e recursos para a participação dos grupos menos fortes.

Não há dúvida, como ressalta BENEVIDES (1991), que a introdução do princípio da participação popular no governo pode ser considerada um "remédio" contra "a tradição oligárquica e patrimonialista", os costumes, as mentalidades, e os valores paternalistas e clientelistas arraigados do povo. A democratização depende, assim, das possibilidades de mudança nos costumes e nas mentalidades, que representam obstáculos à legitimação da participação, numa sociedade marcada por inúmeras formas de exclusão social. Daí faz-se importante a educação para a cidadania como "meio de transformar a capacidade de engajamento sócio político dos atores relevantes e como possibilidade de motivar e incentivar as diversas formas de participação em potenciais fatores de dinamização da sociedade e da ampliação do controle social da coisa pública” (JACOBI 1997, p.2).

Quando se fala na necessidade de reforçar a educação para a cidadania, há de se levar em consideração a importância de ampliar os canais de participação, principalmente quando se constata que apenas uma pequena parcela da população está engajada em movimentos e associações.

Há de se ter em conta, como referem ROUX (1999) e WESTPHAL (1999), outros aspectos envolvidos no processo de educação para a cidadania e que nem 
Cidades Saudáveis no Brasil e os processos participativos: os casos de Jundiaí e Maceió

sempre são considerados pelos grupos sociais. A medida que os processos de coresponsabilidade vão sendo delineados, a gestão pública passa a ser considerada um espaço de deliberar, negociar e consertar, tornando fundamental o aprendizado do procedimento da negociação. E aqui os desafios que se apresentam são inúmeros. De imediato, é preciso supor, como ressalta ROUX (1999), que a negociação não é um simples evento para se chegar a um acordo. Constitui-se um processo dinâmico em que se expressa a complexidade e a possibilidade de aproveitar a divergência. Começa com a elaboração de propostas, mas o acordo que se estabelece não é estático. Por isso, esse processo renova-se constantemente. Mas para que os atores sociais possam ser protagonistas na definição de políticas públicas, têm que ter propostas próprias, principalmente os dos grupos representantes dos setores populares. As organizações da sociedade civil necessitam desenvolver habilidades de negociação, elaboração de projetos e necessitam fazê-los com habilidade. A disponibilização de processo de educação popular, com práticas problematizadoras, podem auxiliar no aumento de poder da sociedade civil, em seu desenvolvimento de habilidades de negociação e outras habilidades também necessárias para o estabelecimento de relações entre a sociedade e o Estado, para evitar o perigo de cooptação, diante das características integradoras presentes nas relações Estado/sociedade civil.

Outra importante dimensão, colocada na gestão compartilhada de projetos que tem relação com a educação política, refere-se ao controle, acompanhamento e manutenção dos acordos, que são responsabilidades que devem ser estabelecidas pelos diferentes atores sociais. O seguimento das ações é indispensável para determinar o caminho, identificar os entraves e as soluções para as ações estabelecidas ou mesmo redefini-las para alcançar metas de interesse geral. $O$ preparo das equipes e de membros das comunidades em metodologias de monitoramento e avaliação de ações tem sido insuficiente para dar cabo de uma tarefa tão complexa. Reside aí uma dificuldade bastante importante, freqüentemente relatada em projetos que envolvem parcerias entre o poder público e as organizações da sociedade civil. Para a PAHO (1999), este é um ponto que tem obstaculizado a implementação de projetos Municípios Saudáveis em toda América Latina. 
Cidades Saudáveis no Brasil e os processos participativos: os casos de Jundiaí e Maceió

Pode-se afirmar, ainda, que uma das questões mais importantes, e um dos desafios do processo de participação na gestão pública, é a garantia de acesso pleno dos cidadãos à informação. A informação é a base para se viabilizar a participação efetiva e é indispensável desde o início do processo administrativo, já que torna transparente a interação pretendida entre Estado e sociedade civil. Informação que possibilite uma visão ampliada das possíveis articulações entre as políticas públicas, informação sobre a destinação de recursos, informação sobre as decisões de governo, informação sobre os direitos institucionais, enfim, informação referenciada na realidade, que permita o estabelecimento dos nexos existentes, e seja suficiente para subsidiar o processo decisório. JACOBI (1992b), chama a atenção para um importante aspecto dessa questão. Segundo ele, o que freqüentemente se observa é a dificuldade dos governos de disseminar a informação. As administrações, normalmente, dispõem de meios para armazená-la, contudo não sabem, ou não querem, fazê-la circular.

O acesso à informação pode potencializar, ainda, a interação pretendida nos processos participativos. É apenas por meio dos fluxos de informações que se possibilita o diálogo, a interpretação dos problemas, limitações e demandas das partes envolvidas na gestão. Além disso, um sistema permanente de informações, que faça uso de todos os meios disponíveis, tem o objetivo de sensibilizar e motivar os indivíduos, que passam a cooperar, desenvolvendo práticas inovadoras e soluções objetivas de atuação conjunta, potencializando, via comunicação e diálogo, o processo decisório e o exercício de controle da gestão pública.

Vários desafios estão relacionados à instituição de mecanismos de gestão de políticas sociais, com o intuito de fortalecer a interação entre o poder público e a população. Alguns autores, como BENEVIDES (1991), COHN (1995b) e JACOBI (1997), entendem que a institucionalização de práticas de participação permite romper com as tradicionais relações autoritárias entre governantes e governados. Implementar mecanismos de estímulo à institucionalidade, respeitando a autonomia e auto-organização, tanto dos setores organizados, quanto dos desorganizados, dentro de uma lógica não imediatista e utilitarista, pode contribuir para ampliar os direitos sociais e de cidadania e construir novas relações entre os atores sociais. 
Cidades Saudáveis no Brasil e os processos participativos: os casos de Jundiaí e Maceió

Instituir e ampliar os canais de participação junto às instâncias da administração pública significa deparar-se com as distintas forças que operam nessa integração. Como diz FOUCAULT (1979), em sua "Microfísica do Poder", os poderes estão disseminados na estrutura social, funcionando como uma rede de dispositivos, que não escapa a nada e a ninguém. Se o poder é um elemento da sociedade, a capacidade de "ganhar poder" existe em todas as pessoas no contexto de suas inúmeras relações com as outras. Esta dinâmica só pode ser entendida, de acordo com LABONTÉ (1994), com base na dialética consenso/conflito, competência profissional/sabedoria leiga, instituições hierárquicas/círculos comunitários. Como o poder é desigual nos contextos sociais, uma condição substantiva é que nos processos gestão partilhada, as formas de poder alcancem maior eqüidade.

Para FARAH (1999), a necessidade de se construírem novos arranjos institucionais e de ampliar cada vez mais a relação poder público-sociedade civilsetor privado é cada vez mais premente. O enraizamento das políticas em um espaço público transcende a esfera estatal e reforça as políticas de longo prazo, com repercussões sobre a eficiência e a efetividade das políticas implantadas. Estudo de Spink, Clemente e Keppke (1998) citado pela autora, revela que 88\% dos programas municipais inscritos em programa de premiação de iniciativas inovadoras em 1996, denominado "Gestão Pública e Cidadania”, da Fundação Getúlio Vargas, sobreviveram à mudança de governo municipal ocorrido em 1997. Desses, 78\% envolviam parcerias com agências governamentais, com entidades civis ou do setor privado e dos que foram interrompidos, $65 \%$ não possuíam formas significativas de parcerias. Esses dados apontam a importância da inclusão de diversos atores na formulação e implementação das políticas locais, que podem por meio de seus protagonismos, instituir novos padrões de cidadania. 


\section{METODOLOGIA}

\section{CONCEPÇÃO DA PESQUISA}

Esta pesquisa tem como objetivo proceder a uma análise da proposta de intervenção em saúde como qualidade de vida - o movimento por Cidades Saudáveis, com ênfase na problemática da participação dos cidadãos.

Embora, numa primeira visão, este objeto de estudo pareça estar delimitado e definido claramente, foi com dificuldades que tentamos alcançá-lo dada a complexidade do objeto de pesquisa. Projetos que se desenvolvem no âmbito da Promoção da Saúde envolvem vários setores da administração pública e diversas organizações da sociedade civil. Desde o início da investigação é fundamental ter claro o que se quer estudar e como fazê-lo. Entretanto, o processo de conhecimento não é linear e uniforme e implica redefinições e novas descobertas que nem sempre são observadas previamente. A própria construção do processo através do qual se adquire conhecimento é dialético.

O estudo dos processos participativos nos projetos Cidades/Municípios Saudáveis passava pela compreensão da gênese desse movimento no Brasil e suas vinculações com os movimentos que vinham se dando em outros países. Assim, foi necessário realizar uma análise histórica da constituição do movimento por Cidades/Municípios Saudáveis, englobando as concepções que lhes servem de suporte. As raras publicações nacionais e internacionais que tratam do tema apresentavam dados esparsos, relatos de experiências que já não existiam. Assim, esta fase possibilitou conhecer onde, como, e em que conjuntura esses projetos foram implementados. Optamos por obter informações através de sujeitos (informanteschave) que tiveram uma posição na definição dos projetos Cidades/Municípios Saudáveis o que os habilita representar pontos de vista de um grupo ou grupos nas cidades. Esta etapa de pesquisa não pretendeu esgotar as questões que envolvem o movimento por Cidades/Municípios Saudáveis no Brasil. Os dados coletados foram somente aqueles pertinentes e necessários a uma análise rápida do tema. Esta fase de investigação já poderia constituir-se por si só numa ampla pesquisa. Entretanto, tínhamos como finalidade principal focalizar os processos participativos e decisórios desses projetos, uma vez que todas as cidades que se aproximaram do movimento 
Cidades Saudáveis no Brasil e os processos participativos: os casos de Jundiaí e Maceió

por Cidades Saudáveis no país, os projetos que foram interrompidos, ou aqueles que estão em andamento, reforçavam a participação como um de seus pressupostos de sustentação.

A participação em saúde, como vimos, têm sido no Brasil, desde os anos de 1970, objeto de pesquisas e de aprofundamento teórico de pesquisadores. Entretanto, a formulação inacabada dos processos participativos em estratégias de Promoção da Saúde levou à necessidade de reelaborar conceitos e articular outros que sustentam propostas desta natureza.

Numa segunda etapa de pesquisa, buscamos verificar até que ponto as iniciativas dos projetos por Cidades/Municípios Saudáveis tinham uma participação efetiva da população e não apenas inclusão formal e instituída de acordo com interesses de grupos específicos. Qualificar a participação da população na definição e no gerenciamento desses projetos, bem como investigar se a relação entre o poder público e as associações da sociedade civil podem encaminhar soluções no sentido de direcionar políticas socialmente relevantes, constituíram também questões que foram investigadas nesta fase de pesquisa.

Este trabalho representou um desafio permanente na busca de encontrar um caminho metodológico que desse conta da compreensão dos elementos presentes neste estudo. Foi, no entanto, nos trabalhos de campo, em confronto direto com as realidade locais, o momento de aprendizagem mais importante, em que o pesquisador, com os atores sociais em interação, puderam ir problematizando e desvendando as complexas redes de significados que foram se estabelecendo nos projetos em desenvolvimento. A premissa desta pesquisa é que esta não se constitui simplesmente em um trabalho de coleta de dados, mas define-se como uma situação de interação.

Esta visão possibilitou construir os significados com base nas experiências concretas, nas relações que são estabelecidas entre os indivíduos e suas correlações com o contexto das cidades. Foi necessário vivenciar as dinâmicas em que elas ocorrem cotidianamente e entender a perspectiva dos grupos locais das cidades por meio de seus relatos Os contatos, as entrevistas e os grupos realizados permitiram essa aproximação. Foram também disponibilizados documentos pelos integrantes dos 
movimentos e por técnicos das prefeituras, sem os quais este trabalho não poderia ter sido realizado.

Do ponto de vista metodológico, portanto, esta pesquisa utilizou fundamentalmente a abordagem qualitativa, buscando, através da perspectiva histórica, apreender o caráter complexo dos fenômenos. Procurou cercar e aprofundar o objeto de conhecimento por meio do entendimento de todas as mediações e correlações, captando os diferentes significados das experiências vividas, de forma a auxiliar na compreensão das relações entre indivíduos, contexto e suas ações. Optou-se, enfim, por escolher um caminho metodológico que privilegiasse a dimensão processual do conhecimento numa perspectiva totalizadora (ANDRÉ 1983; HAGUETTE 1990; MINAYO 1994).

Diferentes técnicas foram utilizadas e combinadas para a coleta de dados quantitativos e qualitativos. Os dados quantitativos permitiram caracterizar as condições objetivas de vida das cidades e focalizar o contexto onde a população se vincula à produção e reprodução da força de trabalho. Os dados qualitativos permitiram, por outro lado, penetrar na subjetividade dos sujeitos, em suas representações e na relação dinâmica que se estabelece nas estruturas sociais. Para MINAYO (1992), as representações, as idéias e a visão de mundo que os atores sociais possuem sobre a realidade correspondem às situações reais de vida. Permitem captar a realidade dinâmica e complexa nas condições em que foram engendradas. Essas visões, por expressarem as contradições e conflitos de um grupo social, podem ser consideradas "matéria-prima para a análise do social”. É preciso atentar, como afirma a autora, que "as representações sociais não conformam a realidade e seria ilusão tomá-las como verdades científicas, reduzindo a realidade à concepção que os atores sociais fazem dela" (MINAYO 1992, p.174).

Assim ao tomarmos um determinado grupo social é importante reconhecer, como bem discute SADER (1988), a importância dos discursos, uma vez que estes irão constituir os sujeitos. É por meio dos discursos que podemos identificar os sujeitos, suas carências, tanto de bens materiais necessários a sua reprodução, quanto de ações e símbolos por meio dos quais eles se reconhecem. 
Cidades Saudáveis no Brasil e os processos participativos: os casos de Jundiaí e Maceió

A fim de analisar o processo de construção da identidade coletiva dos grupos pesquisados nas cidades, e compreender o significado das relações que foram sendo estabelecidas entre esses grupo sociais e os representantes dos governos municipais, foi essencial ao estudo o confronto de dados concretos com as representações. As necessidades objetivas, bem como as necessidades sociais, puderam ser identificadas por meio do estudo das mediações entre as ações e da articulação presente nos discursos emitidos pelos sujeitos coletivos.

Os dados coletados, nas diferentes fases desta investigação, foram analisados através da triangulação metodológica (PATTON 1987). No contexto da pesquisa social, esse tipo de abordagem tem sido usual quando múltiplos métodos de pesquisa são empregados para se analisar um problema. A metodologia da triangulação é considerada fundamental para verificar a propriedade das interpretações, fundadas em dados qualitativos, e permite observar a realidade a partir de distintos ângulos, possibilitando uma discussão interativa e intersubjetiva dos dados. Desta forma, a combinação de múltiplas fontes de dados e vários métodos de coleta objetiva a análise lógica das informações. A utilização de multimeios, própria da proposta de triangulação, garante uma maior validade dos dados, ou seja, na operacionalização de um determinado método, permite que seus problemas e limitações sejam compensados pelo uso de outros métodos. Esta estratégia metodológica parte da constatação de que as ações sociais e as falas dos atores devam ser contextualizadas a fim de esclarecer e aprofundar os aspectos da realidade. A validação dos dados não é realizada por meio de aferição de índices e dados, ou do somatório de dados qualitativos e quantitativos, ao contrário, trata-se de uma análise das relações de contex to com as ações (ADORNO e CASTRO 1994).

\section{FASES DE PESQUISA}

\section{FASE: 1: EsTIMATIVA RÁPIDA dOS PROJETOS CIDADES SAUDÁVEIS NO BRASIL}

Esta fase foi realizada com o objetivo de sistematizar os dados referentes aos projetos Cidades Saudáveis em andamento no Brasil. Esta etapa foi fundamental na escolha dos casos que foram estudados em profundidade, na etapa posterior. Para isso, utilizou-se a técnica da Estimativa Rápida. Este método foi elaborado nos anos de 1970 para levantar dados sobre a vida agrícola e no tratamento de desastres em 
Cidades Saudáveis no Brasil e os processos participativos: os casos de Jundiaí e Maceió

vários países, e tem sido amplamente utilizado na África, Índia e América Latina. A origem desta metodologia surgiu da necessidade de dar respostas mais rápidas do que as que eram oferecidas por "surveys" e outros métodos, inclusive estudos antropológicos. Está baseada no reconhecimento de que quem vive num determinado local oferece conhecimentos e informações mais ricas e de maior valor pela sua familiaridade com as situações particulares (VINCE-WHITMAN 1997).

Essas técnicas simplificadas de coleta de dados desenvolvidas nos últimos anos por diferentes setores trazem, para MINAYO (1991), o desafio de unir a antropologia e a avaliação de programas de saúde. Ao inserir-se no campo das políticas sociais, a antropologia desloca o seu papel tradicional de disciplina básica para o campo da pesquisa estratégica.

Trata-se, portanto, de uma técnica simples, seja no conteúdo da informação, onde se busca coletar somente a informação estritamente necessária, seja nas técnicas utilizadas, de coleta, análise e apresentação de dados. Isto não significa necessariamente que as análises não sejam realizadas seguindo um determinado rigor metodológico. Do ponto de vista da análise do material MINAYO (1991) recomenda que os dados coletados sejam vinculados a uma maior totalidade, pois não se trata de aglomerações isoladas.

Os dados coletados foram levantados em três principais fontes, no período de julho à setembro de 1998:

1. nos registros escritos existentes ou fontes secundárias;

2. em entrevistas com informantes-chave, utilizando o roteiro em anexo;

3. na observação da área.

Os projetos, bem como a população de estudo, foram identificados em levantamentos de publicações especializadas, bem como por meio de informações orais de profissionais (informantes - chaves) que trabalham com a temática Cidades Saudáveis e membros da Oficina Permanente de Estudos e Programas sobre Cidades Saudáveis ${ }^{14}$, e encontram-se relacionados na tabela 2 , que ilustra as 49 entrevistas realizadas em 19 cidades brasileiras.

\footnotetext{
${ }^{14}$ A Oficina Permanente de Estudos e Programas sobre Cidades Saudáveis constitui-se em um fórum interinstitucional e intersetorial, criado em 1997, que tem como principais objetivos: estimular e
} 
Cidades Saudáveis no Brasil e os processos participativos: os casos de Jundiaí e Maceió

As informações buscadas em cada uma das cidades, por meio da Estimativa Rápida, foram obtidas por meio de um questionário/roteiro semi-estruturado. Este questionário - guia foi útil para dirigir as entrevistas, acompanhá-las e para registrar de maneira ordenada as informações. Mais do que uma simples aplicação de um questionário, buscou-se estabelecer com os entrevistados um diálogo aberto e ativo que permitiu que expressassem elementos subjetivos importantes ao entendimento da problemática. Foi necessário entender a particularidade de cada cidade, de cada situação, subordinada às formas como está organizando o movimento por Cidades Saudáveis no Brasil. As informações coletadas podem ser observadas no Roteiro de Estimativa Rápida, do Anexo 1, e foram assim agrupadas:

- histórico: origem e processo de desenvolvimento do projeto local

- políticas estabelecidas, capacidades, interesses e necessidades, no decorrer do processo;

- conceitos, atitudes e habilidades dos diferentes grupos envolvidos, relacionados à promoção da saúde;

- mecanismos de comunicação, colaboração e parcerias;

- recursos humanos e materiais com que o projeto conta, apoios técnicos e financeiros;

- programas, ações e serviços criados e oferecidos.

A análise desta fase de investigação resultou no capítulo 4 deste trabalho intitulado Cidades/Municípios Saudáveis no Brasil.

aprofundar os referenciais teóricos acerca do tema Cidades Saudáveis, promover a realização de novas experiências programáticas em municípios; apoiar projetos em curso; promover a troca de experiências em andamento. 
Cidades Saudáveis no Brasil e os processos participativos: os casos de Jundiaí e Maceió

Tabela 2 - Cidades visitadas relacionadas com os Projetos Cidades Saudáveis no Brasil

\begin{tabular}{|c|c|c|}
\hline Cidade & Data & Atividades Realizadas (Gestão Administrativa dos entrevistados) \\
\hline $\begin{array}{l}\text { São Paulo } \\
\text { SP }\end{array}$ & $\begin{array}{l}\text { Julho / } \\
\text { Agosto de } \\
98\end{array}$ & $\begin{array}{l}\text { - } 03 \text { Entrevistas: Ex-Secretário de Saúde; Ex-Diretor de Regional de } \\
\text { Saúde; e Assessora de Meio Ambiente da prefeita (Gestão 89-92) }\end{array}$ \\
\hline $\begin{array}{l}\text { Diadema } \\
\text { SP }\end{array}$ & $\begin{array}{l}\text { Agosto de } \\
98\end{array}$ & $\begin{array}{l}\text { - } 01 \text { Entrevista: Ex-Assessor de Saúde bucal e Ex-Diretor do } \\
\text { Departamento de Atenção Ambulatorial Coordenador (Gestão 93-96) e } \\
\text { contato com Ex Secretário da Saúde }\end{array}$ \\
\hline $\begin{array}{l}\text { Campinas } \\
\text { SP }\end{array}$ & $\begin{array}{l}\text { Julho de } \\
98\end{array}$ & $\begin{array}{l}\text { - } 02 \text { Entrevistas: Ex-Secretário de Saúde; Ex-Coordenadora do Projeto } \\
\text { (Gestão 93-96) }\end{array}$ \\
\hline $\begin{array}{l}\text { Jundiaí } \\
\text { SP }\end{array}$ & $\begin{array}{l}\text { Agosto de } \\
98\end{array}$ & $\begin{array}{l}\text { - } 03 \text { Entrevistas: } 02 \text { Ex-Coordenadores do Projeto e Atual } \\
\text { Coordenador do Projeto (Gestão 93-96 / Gestão Atual) }\end{array}$ \\
\hline $\begin{array}{l}\text { Santos } \\
\text { SP }\end{array}$ & $\begin{array}{l}\text { Agosto de } \\
98\end{array}$ & $\begin{array}{l}\text { - } \quad \text { 01 Entrevista: Ex-Secretário de Saúde (Gestão 93-96) e contato com } \\
\text { Presidente do Conselho Municipal de Saúde (Gestão Atual) }\end{array}$ \\
\hline $\begin{array}{l}\text { Vargem } \\
\text { G } \underline{\text { de }} \text { Pta } \\
\text { SP }\end{array}$ & $\begin{array}{l}\text { Agosto de } \\
98\end{array}$ & $\begin{array}{l}\text { - } \quad 02 \text { Entrevistas: Ex-Secretário de Saúde; e Representante da } \\
\text { Faculdade de Saúde Pública da USP (Gestão Atual) }\end{array}$ \\
\hline $\begin{array}{l}\text { Iraquara } \\
\mathrm{BA}\end{array}$ & Não Visitado & $\begin{array}{l}\text { - Contato com Ex vice-prefeito (gestão 93-96) e com Secretário da } \\
\text { Saúde (Gestão Atual) }\end{array}$ \\
\hline $\begin{array}{l}\text { Céu Azul } \\
\text { PR }\end{array}$ & $\begin{array}{l}\text { Agosto de } \\
98\end{array}$ & - 01 Entrevista: Secretário de Saúde (Gestão Atual) \\
\hline $\begin{array}{l}\text { Chopinzinho } \\
\text { PR }\end{array}$ & $\begin{array}{l}\text { Agosto de } \\
98\end{array}$ & $\begin{array}{l}\text { - } 06 \text { Entrevistas: Secretários da Saúde (Ex-Prefeito na Gestão 93-96), } \\
\text { Agricultura, Educação, Habitação, Ação Social, e Indústria e Comércio } \\
\text { (Gestão Atual) }\end{array}$ \\
\hline $\begin{array}{l}\text { Curitiba } \\
\text { PR }\end{array}$ & $\begin{array}{l}\text { Agosto de } \\
98\end{array}$ & $\begin{array}{l}\text { • } 04 \text { Entrevistas: Diretor de Planejamento do IMAP (Instituto } \\
\text { Municipal de Administração Pública); } 02 \text { Técnicos do IPPUC (Inst. De } \\
\text { Pesquisa e Planejamento Urbano de Curitiba; e 01 Ex-Técnico da Secr. } \\
\text { Est. Saúde (Gestão Atual / Gestão 93-96) }\end{array}$ \\
\hline $\begin{array}{l}\text { Palmeira } \\
\text { PR }\end{array}$ & $\begin{array}{l}\text { Agosto de } \\
98\end{array}$ & $\begin{array}{l}\text { - } 03 \text { Entrevistas: Secretário da Saúde; } 02 \text { técnicos da Secretaria } \\
\text { Municipal de Saúde (Gestão Atual) }\end{array}$ \\
\hline $\begin{array}{l}\text { Fortaleza } \\
\text { CE }\end{array}$ & $\begin{array}{l}\text { Agosto de } \\
98\end{array}$ & $\begin{array}{l}\text { 01 Entrevista com Representante da Secretaria de Desenvolvimento } \\
\text { Social do Município. }\end{array}$ \\
\hline $\begin{array}{l}\text { Sobral } \\
\text { CE }\end{array}$ & $\begin{array}{l}\text { Agosto de } \\
98\end{array}$ & $\begin{array}{l}\text { 02 Entrevistas: Secretário de Saúde; e } 01 \text { Professor da Escola de Saúde } \\
\text { Pública do Ceará (Gestão Atual) }\end{array}$ \\
\hline $\begin{array}{l}\text { Crateús } \\
\text { CE }\end{array}$ & $\begin{array}{l}\text { Agosto de } \\
98\end{array}$ & $\begin{array}{l}\text { - } 02 \text { Entrevistas: Secretário da Saúde; e Coordenador do Projeto } \\
\text { (Gestão Atual) }\end{array}$ \\
\hline $\begin{array}{l}\text { Anadia } \\
\text { AL }\end{array}$ & $\begin{array}{l}\text { Agosto de } \\
98\end{array}$ & $\begin{array}{l}\text { - } \quad 05 \text { Entrevistas: Prefeita; Secretário da Saúde; Secretário da } \\
\text { Educação; Secretário da Agricultura e Meio Ambiente; Assessora de } \\
\text { Planejamento da Secretaria de Saúde (Gestão Atual) }\end{array}$ \\
\hline $\begin{array}{l}\text { Arapiraca } \\
\text { AL }\end{array}$ & $\begin{array}{l}\text { Agosto de } \\
98\end{array}$ & $\begin{array}{l}\text { - } 04 \text { Entrevistas: Secretária de Saúde; } 02 \text { Técnicos do Departamento } \\
\text { de Planejamento da Secretaria da Saúde; e Coordenador do Programa } \\
\text { Saúde da Família (Gestão Atual) }\end{array}$ \\
\hline $\begin{array}{l}\text { Flexeiras } \\
\text { AL }\end{array}$ & $\begin{array}{l}\text { Agosto de } \\
98\end{array}$ & $\begin{array}{l}\text { - } 04 \text { Entrevistas: Prefeita; Secretária de Saúde; Secretária de Educação } \\
\text { e } 01 \text { Técnica do Depto. Administração (Gestão Atual) }\end{array}$ \\
\hline $\begin{array}{l}\text { Maceió } \\
\mathrm{AL}\end{array}$ & $\begin{array}{l}\text { Agosto de } \\
98\end{array}$ & $\begin{array}{l}\text { - } 03 \text { Entrevistas: Secretária da Saúde; } 01 \text { Técnica da Secretaria da } \\
\text { Saúde; e 01 Professora da Univ. Federal Alagoas (Gestão Atual) }\end{array}$ \\
\hline $\begin{array}{l}\text { Dionísio e } \\
\text { S.J. Goiabal } \\
\text { MG }\end{array}$ & $\begin{array}{l}\text { Setembro } \\
\text { de } 98\end{array}$ & $\begin{array}{l}\text { - } 02 \text { entrevistas: Professor da Escola de Saúde de Minas Gerais, } 01 \\
\text { Coordenadora do Grupo Técnico Decisório }\end{array}$ \\
\hline \multicolumn{3}{|c|}{ TOTAL DE CIDADES: 20} \\
\hline
\end{tabular}




\section{FASE 2: ESTUDO DE CASO EM DUAS CIDADES BRASILEIRAS}

O desenvolvimento do estudo de caso teve início com a seleção e delimitação dos casos. Esta se constituiu uma importante etapa para análise da situação estudada. Embora o caso tenha uma referência significativa e o alcance da generalização possa ser limitado, pode contribuir para a compreensão do contexto. Isto implica que o objeto de estudo seja examinado como uma representação singular da realidade, retratada de forma completa e profunda (ANDRÉ 1984).

A seleção dos municípios brasileiros para realizar o estudo de caso respondeu aos seguintes critérios:

- cidades inseridas no movimento Cidades Saudáveis que pertencem a duas diferentes regiões do país;

- cidades que têm histórico de desenvolvimento superior a 1 ano;

- projetos que têm como princípio norteador a participação;

- projetos com compromisso dos governos locais;

- projetos de duas diferentes regiões do país.

Dois estudos de caso foram realizados, um em Jundiaí, Estado de São Paulo, e outro em Maceió, capital do Estado de Alagoas. Jundiaí conta com uma população de 294 mil habitantes e foi uma das primeiras cidades brasileiras a inserir-se no movimento por Cidades Saudáveis, em 1994. Mantém o projeto até os dias de hoje, e teve, desde o início, envolvimento de vários segmentos da sociedade civil e da administração pública. Maceió possui cerca de 880 mil habitantes e discute, desde 1995, a possibilidade de implantação do projeto. Desde 1996 desenvolve projetos em comunidades, denominando-as Comunidades Saudáveis, em duas localidades, Pontal da Barra e Cruz das Almas - Grota do Arroz, Grota do São Rafael e loteamento Santo Onofre, seguindo a tendência de realizar experiências localizadas, como ocorreu em São Paulo e Curitiba e outras cidades de maior porte do Canadá e Estados Unidos.

Este estudo foi estruturado em 3 módulos de análise: 


\section{Módulo 1 : Análise documental}

Neste módulo, buscamos identificar os projetos implantados, seus objetivos, o desenho organizacional estruturado para viabilizar as ações implantadas e as atividades em desenvolvimento. Uma breve caracterização das cidades foi realizada por meio de dados secundários, coletados junto à Fundação SEADE, IBGE, PNUD e documentos colhidos nas prefeituras locais, em secretarias de governo. O histórico dos projetos, suas ações e estratégias de implementação foram reconstituídos por meio de documentos coletados nas prefeituras, junto aos representantes de associações comunitárias, nos jornais locais. Os documentos da Prefeitura Municipal de Jundiaí, quando são referidos na análise, podem ser identificados por PMJ e os da Prefeitura Municipal de Maceió, por PMM.

Este levantamento possibilitou identificar na cidade de Jundiaí um enorme número de matérias de jornais, levando a necessidade de buscar uma metodologia de análise que possibilitasse sistematizar os discursos existentes e persistentes da mídia local sobre a temática Cidade Saudável. Esta fase foi realizada apenas na cidade de Jundiaí, que conta com uma assessoria de imprensa da prefeitura local que sistematiza e organiza as matérias publicadas. A pesquisa nos jornais locais na cidade de Maceió foi dificultada pela organização dos arquivos que não permite reproduzir as matérias publicadas.

Esta etapa de pesquisa foi baseada no trabalho desenvolvido por LEFÈVRE e LEFÈVRE (1999), que apresentam um método de análise de representações sociais, visando a organização dos dados discursivos. Partindo do pressuposto de que a mídia na cidade de Jundiaí estrutura um determinado significado ao projeto Cidade Saudável, ou seja, torna público conceitos, estratégias e opiniões, a aplicação desta metodologia trouxe uma contribuição para sistematizar e analisar o vasto material selecionado.

De acordo com os autores, quatro figuras metodológicas são definidas com vistas a tornar mais clara uma dada representação social. São elas, a ancoragem, conceitos, teorias, pressupostos que dão sustentação ao discurso; a idéia central: transcrições fiéis de partes significativas dos depoimentos; as expressões-chaves: transcrições literais de partes mais significativas dos depoimentos e, finalmente, a 
Cidades Saudáveis no Brasil e os processos participativos: os casos de Jundiaí e Maceió

construção do Discurso do Sujeito Coletivo (DSC), realizada a partir da definição de categorias, que torna os depoimentos equivalentes e sistematizados em um só discurso -síntese. Cada discurso-síntese foi elaborado a partir dos discursos veiculados, de tal forma que representam literalmente aquilo que foi publicado. A inclusão de conectivos foi feita para dar sentido e ligação entre os diversos discursos. Os Discursos do Sujeito Coletivo foram elaborados a partir da definição de duas categorias, que tornaram os depoimentos equivalentes e sistematizados em um só discurso. No corpo do trabalho, parte dos discursos quando referidos, vem seguidos das iniciais DSC ${ }^{15}$. O Anexo 2 mostra, por meio de quadros, o procedimento adotado na sistematização dos artigos. $\mathrm{O}$ primeiro foi construído para verificar $\mathrm{o}$ desenvolvimento histórico do Projeto Jundiaí Cidade Saudável (PJCS), através das matérias publicadas. $\mathrm{O}$ segundo e o terceiro quadros mostram como, para cada uma das categorias criadas, foram extraídas as expressões-chaves e identificadas as idéias centrais, com as quais produziu-se os DSC. No Anexo 3 apresentamos os Discursos do Sujeito Coletivo na íntegra.

Na categoria 1, a reconstrução do conceito de Cidade Saudável como fato público, foram identificados quatro Discursos do Sujeito Coletivo que são : DSC do conceito de Cidade Saudável; DSC das características do Projeto Jundiaí Cidade Saudável; DSC do diagnóstico; DSC sobre a participação das organizações da sociedade civil.

$\mathrm{Na}$ categoria 2, como a mídia publiciza o discurso dos atores sociais envolvidos, bem como sua atuação, foram definidos quatro Discursos do Sujeito Coletivo: DSC do poder público; DSC das organizações da sociedade civil; DSC da coordenação do PJCS e DSC do Canadá.

\section{Módulo 2: Análise dos atores que participam dos projetos}

Neste segundo módulo de análise, buscamos caracterizar a participação nos projetos, tanto do Estado quanto da sociedade civil organizada, para construir os Mapas de Integração e Participação. Esta etapa foi realizada com base nas

\footnotetext{
${ }^{15}$ A fim de facilitar a localização dos textos dos jornais que compõem os DSC's foi adotado o sistema cronológico numerado, diferente do sistema alfabético utilizado para as outras referências bibliográficas.
} 
Cidades Saudáveis no Brasil e os processos participativos: os casos de Jundiaí e Maceió

opiniões e expectativas dos participantes dos projetos. Para isso, foram realizadas entrevistas individuais, com pessoas consideradas informantes-chave, pela posição que ocupam no desenvolvimento dos projetos Cidades Saudáveis: lideranças de grupos organizados da população, representantes de ONG's, membros de equipe técnica, representantes do poder executivo. Para cada um desses grupos foram elaboradas perguntas para preenchimento de um formulário, que permitiu identificar como se envolveram no projeto, se participam ou deixaram de participar e porque (Anexo 4).

\section{Módulo 3: Análise da participação social nos projetos}

Neste módulo de análise, investigamos as informações sobre conhecimentos, crenças e percepções que os grupos participantes têm a respeito dos projetos em desenvolvimento. Buscamos também discutir até que ponto a parceria dos grupos sociais com o governo local pode contribuir para uma gestão de cidade que possibilite a ampliação do controle social na construção de políticas públicas saudáveis

Nesta etapa, foram realizados grupos de discussão - grupo focal e entrevistas em profundidade. A utilização de grupos focais na área de saúde no Brasil, especialmente em programas educativos, é referida por WESTPHAL e col. (1996). Possibilita que os participantes expressem suas percepções, crenças e representações sociais a respeito de um tema específico, permitindo às pessoas pensar coletivamente uma temática que faz parte do cotidiano.

Os participantes dos grupos focais foram escolhidos com base nos grupos já delineados na fase de entrevistas. Em Jundiaí o grupo focal foi realizado em 18 de agosto de 1999, com o Comitê Cidade Saudável, que agrega o poder público e organizações da sociedade civil. As discussões realizadas neste grupo focal podem ser identificadas nas análises que o incluem como GF1. Em Maceió foram realizados dois grupos focais. Um com grupos comunitários e instituições de saúde na comunidade de Pontal da Barra (GF2) em 28 de maio de 1999, e outro com grupos comunitários e instituições de saúde em Cruz das Almas (GF3) em 02 de junho de 1999 (Anexo 5, Grupo Focal: instruções gerais e roteiro). 
As entrevistas em profundidade foram realizadas por meio de gravação dada a necessidade de se obter dados que auxiliassem no entendimento dos processos de participação nos projetos. Para THIOLLENT (1987), a seleção das pessoas a serem entrevistadas intensivamente não obedece a regras mecânicas. Esta seleção supõe a disponibilidade do entrevistado, e resulta de uma avaliação da relevância ou da representatividade social e não estatística das pessoas. Esta avaliação, de acordo com o autor, fica a critério da "intuição" do pesquisador. Em Jundiaí foram realizadas quatro entrevistas em profundidade, com os três coordenadores do projeto, denominadas EC1, EC2, EC3 e com o ex-secretário da Coordenadoria do Planejamento, chamada ESP. Em Maceió foram feitas seis entrevistas, com a prefeita da cidade, com a ex-secretária da saúde, com a secretária atual de saúde, com a coordenadora do projeto, e com os presidentes de duas associações de moradores, que receberam a indicação: EP, ES1, ES2, EC, EA1, EA2. Na apresentação dos resultados, essas falas aparecem com suas respectivas indicações.

As perguntas-chave realizadas nos segundo e terceiro módulos foram baseadas no esquema proposto por MATO (1996), em Guia de Evaluar Participación Social, com algumas adaptações. O autor define aspectos ou dimensões da participação e elabora a partir daí perguntas-chave que, de acordo com autor, podem se transformar em perguntas mais específicas, que deverão adaptar-se às realidades locais ou a cada estratégia ou programa de saúde. As perguntas referentes aos aspectos de amplitude, profundidade ou intensidade e modalidades constituíram os Mapas de Integração e Participação, onde se estabeleceu um desenho dos grupos participantes ou não dos projetos. Os aspectos relativos ao impacto ou efetividade, sustentabilidade ou probabilidade de continuidade $e$ renovação foram investigados por meio dos grupos focais, e têm por objetivo qualificar a participação nos projetos e verificar até que ponto a sociedade civil pode agir em parceria com o governo local para fomentar a "renovação".

No quadro abaixo podem ser observados os aspectos da participação e as respectivas perguntas-chave. 
Cidades Saudáveis no Brasil e os processos participativos: os casos de Jundiaí e Maceió

\begin{tabular}{c|l}
\hline $\begin{array}{c}\text { ASPECTOS OU DIMENSÕES DA } \\
\text { PARTICIPAÇÃO }\end{array}$ & \multicolumn{1}{c}{ PERGUNTAS-CHAVE } \\
\hline Amplitude ou extensão & $\begin{array}{l}\text { Quem participa? } \\
\text { Quem não participa? } \\
\text { Por quê? }\end{array}$ \\
\hline Profundidade ou intensidade & Em que tipos de atividades participam? \\
\hline Modalidade & $\begin{array}{l}\text { Como se dá a participação? De que maneira } \\
\text { participam? } \\
\text { Qual a estrutura da participação? }\end{array}$ \\
\hline Impacto ou efetividade & $\begin{array}{l}\text { Que impacto têm essas experiências de } \\
\text { participação no alcance de metas de saúde? } \\
\text { E com relação a metas em outros setores? }\end{array}$ \\
\hline Sustentabilidade & $\begin{array}{l}\text { De que maneira essas experiências contribuem } \\
\text { para assegurar mais e melhor participação no } \\
\text { futuro? }\end{array}$ \\
\hline Renovação & $\begin{array}{l}\text { Tem sido desenvolvidas formas de } \\
\text { cooperação? Tem se formado redes de apoio } \\
\text { social? }\end{array}$ \\
\hline
\end{tabular}

\section{Módulo 4: Articulação das análises parciais}

A partir dos conceitos explicitados nos capítulos iniciais deste trabalho, e com base nas análises realizadas no Capítulo 5, em que foram apresentados os dois estudos de caso, estruturamos o Capítulo 6 deste estudo: Cidadania, democracia e os desafios da gestão compartilhada. Ao longo desta análise, procuramos mostrar como alguns elementos e conceitos inscritos nas bases teóricas do movimento por Cidades/Municípios Saudáveis se delineiam nos projetos estudados em profundidade nas cidades de Jundiaí e Maceió. 


\section{AS CIDADES/MUNICÍPIOS SAUDÁVEIS NO BRASIL}

\section{O INÍCIO DO MOVIMENTO POR CIDADES/MUNICÍPIOS SAUDÁVEIS NO BRASIL}

Quais são as cidades brasileiras que se inserem no movimento por Cidades Saudáveis? Ao iniciarmos este trabalho, deparamo-nos com a dificuldade de definir critérios ou parâmetros que pudessem responder a esta questão. Diferentemente de outros países da América Latina, do Canadá ou Europa, o Brasil não possui um órgão ou instituição que aglutine essas experiências e promova incentivo à implementação de outras. Só recentemente, nos finais dos anos de 1990, algumas universidades e instituições, têm ampliado o debate de formação de uma rede brasileira como uma estratégia que possibilite ampliar o movimento no país.

No Brasil, de acordo com o IBGE (1999), existem 5512 municípios, e poderíamos elencar centenas deles que possuem projetos inovadores, com premissas de fortalecer os governos locais, a gestão intersetorial e participativa, objetivando a melhoria de qualidade de vida e a cidadania, pressupostos que definem um projeto por uma Cidade Saudável.

Com base em referências bibliográficas produzidas e de trabalhos apresentados em congressos foram identificadas as primeiras cidades que se declaravam Cidades Saudáveis. Pôde-se verificar que essas cidades, em algum momento histórico, aproximaram-se do ideário por Cidades Saudáveis, especialmente fomentado pela Organização Mundial da Saúde e por suas agências regionais, e começaram a desenvolver iniciativas de implementação de políticas públicas que incorporam pressupostos como a intersetorialidade, a participação social e a saúde como qualidade de vida.

Como vimos, as diretrizes dos projetos Cidades Saudáveis estão baseadas nas dos países desenvolvidos, e sua implantação, nos países em desenvolvimento, começa a se dar nos anos de 1990. Assim como nos demais países da América Latina, as primeiras iniciativas do Cidade Saudável, no Brasil, datam do início da década de 90. 
Cidades Saudáveis no Brasil e os processos participativos: os casos de Jundiaí e Maceió

Podemos verificar duas fases distintas de aproximação das cidades a esta filosofia. Na primeira, há uma relação mais direta com o movimento canadense, especialmente com a cidade de Toronto, cujos técnicos participam de seminários nas cidades brasileiras, com o intuito de sensibilizá-las para o tema. Há intercâmbio entre os países e um acompanhamento mais direto no desenvolvimento das experiências. Esta fase se inicia com a experiência da cidade de São Paulo em 1991, apoiada por um convênio de cooperação técnica, existente desde o final dos anos de 1980, entre as cidades de São Paulo e Toronto, consideradas cidades-irmãs. O ano de 1994 pode, também, ser considerado um marco dos projetos Cidades Saudáveis no Brasil. Intensifica-se o contato com o Canadá e com a Organização Pan-Americana de Saúde (OPAS), que começa a incentivar projetos em toda América Latina.

Nos anos de 1994 e 1995 dez cidades incluíram em suas agendas políticas, projetos na perspectiva deste ideário: Diadema, Campinas, Jundiaí, Santos, no Estado de São Paulo; Iraquara na Bahia; Céu Azul, Chopinzinho, Curitiba, Palmeira, no Estado do Paraná, e Maceió em Alagoas. Numa segunda etapa, podemos verificar um protagonismo maior das Universidades, de órgãos como o CONASEMS e da Fundação Kellogg, que promovem colaboração técnica e/ou financeira. Estas instituições apoiaram, nos anos de 1996 e 1997, projetos nas cidades de Vargem Grande Paulista no Estado de São Paulo, Sobral, Crateús, e Fortaleza no Ceará, Anadia, Arapiraca, Flexeiras, em Alagoas; Dionísio e São José do Goiabal em Minas Gerais.

Nos anos de 1990, vários encontros e seminários tiveram o objetivo de discutir as premissas do projeto Cidade Saudável e aglutinar experiências. Algumas cidades realizaram suas conferências municipais de saúde tendo o Cidade Saudável como tema. Nesse mesmo período, algumas iniciativas ampliaram as discussões em âmbito estadual e nacional.

A Secretaria de Saúde do Estado do Paraná, com o objetivo de sensibilizar os municípios para a proposta, promoveu, no ano de 1994, uma série de atividades, como reuniões, visitas e ações, para envolver os municípios do Estado. Um grupo de técnicos ficou responsável por assessorar as ações. Promoveu, ainda, em 1994, o encontro Saúde Cidade, com o apoio da OPAS, convidando cerca de 20 cidades do 
Cidades Saudáveis no Brasil e os processos participativos: os casos de Jundiaí e Maceió

Estado, que tinham possibilidades de realizarem projetos inovadores. A cidade de Campinas, Estado de São Paulo, apresentou neste encontro, sua experiência, e os marcos conceituais do projeto Cidades Saudáveis foram debatidos com especialistas no tema. Deste encontro, resultou a primeira publicação sobre o assunto, intitulada Municípios Saudáveis: iniciativas de implantação. (SESA/OPAS 1996). Chopinzinho, pequena cidade do oeste do Paraná, que experimentava mudanças na lógica administrativa e política, em particular nas áreas de agricultura e educação, serviu de modelo, e seu prefeito participou de inúmeros encontros no Estado, auxiliando no trabalho de sensibilização de outras cidades.

O I Congresso de Secretários Municipais de Saúde das Américas, ocorrido em 1995, e sua respectiva Carta de Fortaleza, promoveram uma reflexão sobre as possibilidades da adoção da filosofia de Cidades Saudáveis, tendo sido um importante fórum de disseminação de idéias (CARTA DE FORTALEZA 1995).

Em 1996, a cidade de Campinas sediou o I Congresso Latino Americano para Cidades e Comunidades Saudáveis, que promoveu um amplo debate sobre a implementação de projetos.

Em 1997 a cidade de Vargem Grande Paulista realizou o Fórum RegionalMunicípios Saudáveis, que contou com a participação de prefeitos, secretários de saúde de cidades vizinhas e técnicos de pequenas cidades do nordeste, interessados em implementar propostas em seus municípios.

Também no ano de 1997 o V Congresso Brasileiro de Saúde Coletiva e o V Congresso Paulista de Saúde Pública promoveram a Oficina de Trabalho sobre Cidades/Municípios Saudáveis com a participação de 30 entidades que culminou com a formação do grupo Oficina Permanente de Estudos e Programas sobre Cidades/Municípios Saudáveis, de caráter interinstitucional sediado na Faculdade de Saúde Pública da Universidade de São Paulo. No ano seguinte a Oficina promoveu dois seminários nacionais: Movimento Municípios Saudáveis: aspectos conceituais, legais e operacionais e Articulação entre agendas sociais: agenda 21, município saudável, comunidade solidária e outras.

No ano de 1998, dois eventos foram realizados na perspectiva de discutir a formação de redes, quer em âmbito nacional, quer no estadual, a exemplo do I Fórum 
Brasileiro de Municípios Saudáveis ocorrido em Sobral, Estado do Ceará, no período de 20 a 22 de agosto (WESTPHAL, MOTTA e BÓGUS 1998; CARTA DE SOBRAL 1998), e do I Fórum Alagoano de Municípios Saudáveis ocorrido em Maceió, Estado de Alagoas em 24 de agosto.

A figura 1, mostra a distribuição inicial de projetos Cidades Saudáveis no Brasil e a tabela 3 aponta o ano de início das atividades e a situação do projeto até 1998, período em que este estudo foi realizado. Podemos verificar que, a partir de 1998, outras cidades têm se aproximado do movimento por Cidades Saudáveis, motivadas pela discussão de formação de redes estaduais, como no Estado de Alagoas, e pela realização de eventos que tentam estimular o desenvolvimento de projetos nos municípios. ${ }^{16}$

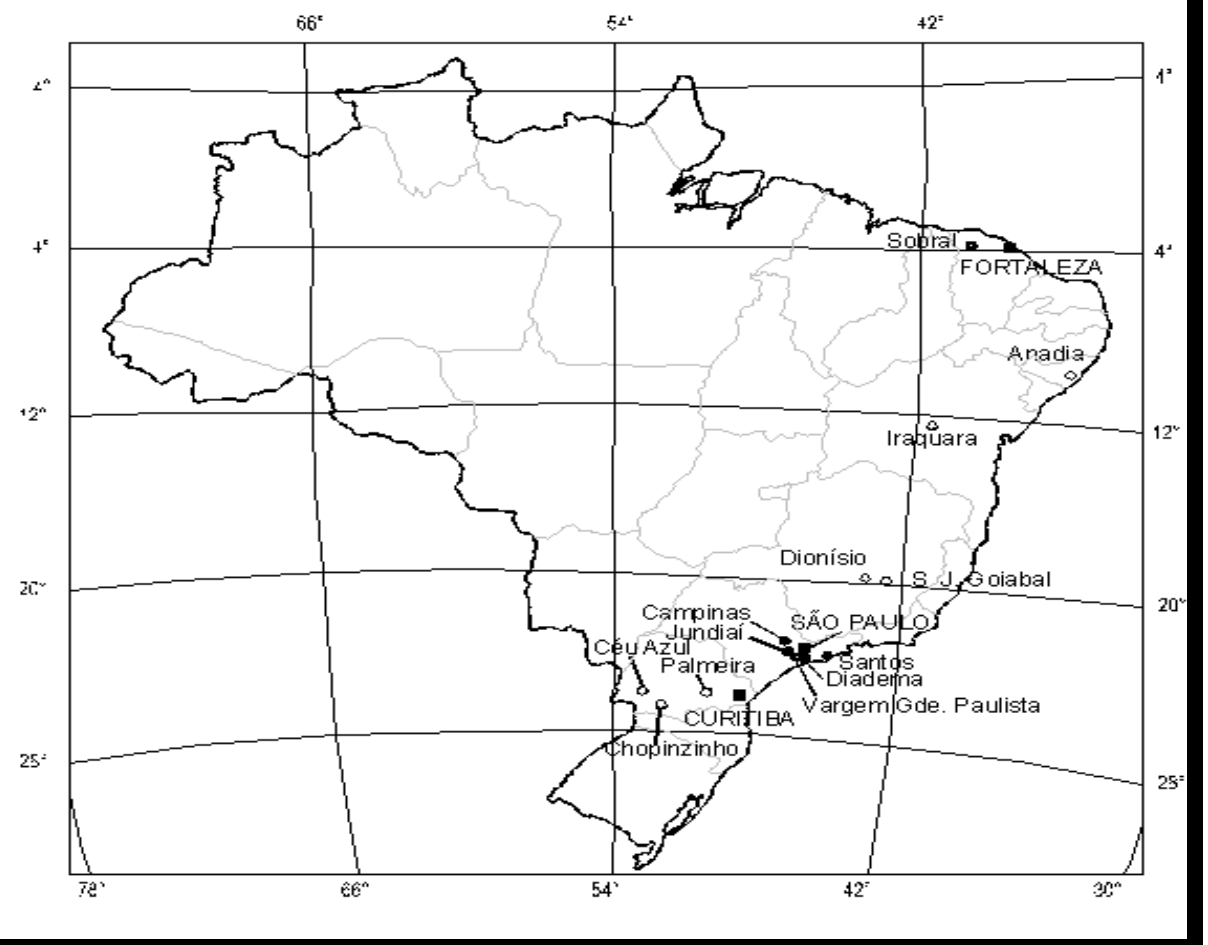

Figura 1- Mapa de distribuição inicial dos Projetos Cidades Saudáveis no Brasil.

\footnotetext{
${ }^{16}$ Às 13 cidades que apontamos como partícipes do movimento por Cidades Saudáveis até o ano de 1998, o Ministério da Saúde agrega, hoje, outras 27. São elas: São Miguel dos Campos, Cacimbinhas, Cajueiro e Muricí em Alagoas; Brasília; Goiânia em Goiás; Nova Mutum no Mato Grosso; Aguanil, Campo Belo, Cana Verde, Candeias, Cristais, Perdões, Santana do Jacaré e Santo Antonio do Amparo em Minas Gerais; Pato Branco no Paraná; Campina Grande e Piancó na Paraíba; Cabo de Santo Agostinho e Camaragibe em Pernambuco; Miguel Alves no Piauí; Niterói e Porto Real no Rio de
} 
Tabela 3 - Projetos Cidades Saudáveis no Brasil. Início do Projeto e Situação Atual

\begin{tabular}{|c|c|c|c|}
\hline Cidade & Data da Visita & $\begin{array}{c}\text { Início da } \\
\text { Atividade }\end{array}$ & Situação Atual \\
\hline $\begin{array}{l}\text { São Paulo } \\
\text { SP }\end{array}$ & \begin{tabular}{|l} 
Julho / Agosto \\
de 98
\end{tabular} & 1991 & Projeto Interrompido \\
\hline $\begin{array}{l}\text { Diadema } \\
\text { SP }\end{array}$ & Agosto de 98 & 1994 & $\begin{array}{l}\text { Cidade que se aproximou } \\
\text { do movimento }\end{array}$ \\
\hline $\begin{array}{l}\text { Campinas } \\
\text { SP }\end{array}$ & Julho de 98 & 1994 & Projeto Interrompido \\
\hline $\begin{array}{l}\text { Jundiaí } \\
\text { SP }\end{array}$ & Agosto de 98 & 1994 & Projeto em Atividade \\
\hline $\begin{array}{l}\text { Santos } \\
\text { SP }\end{array}$ & Agosto de 98 & 1994 & Projeto Interrompido \\
\hline $\begin{array}{c}\text { Vargem Grande } \\
\text { Paulista / SP }\end{array}$ & Agosto de 98 & 1997 & Projeto em Atividade \\
\hline $\begin{array}{c}\text { Iraquara } \\
\text { BA }\end{array}$ & Não Visitado & 1994 & Projeto Interrompido \\
\hline $\begin{array}{l}\text { Céu Azul } \\
\text { PR }\end{array}$ & Agosto de 98 & 1995 & $\begin{array}{l}\text { Cidade que se aproximou } \\
\text { do movimento }\end{array}$ \\
\hline $\begin{array}{l}\text { Chopinzinho } \\
\text { PR }\end{array}$ & Agosto de 98 & 1995 & Projeto em Atividade \\
\hline $\begin{array}{l}\text { Curitiba } \\
\text { PR }\end{array}$ & Agosto de 98 & 1994 & Projeto em Atividade \\
\hline $\begin{array}{c}\text { Palmeira } \\
\text { PR }\end{array}$ & Agosto de 98 & 1995 & Projeto Interrompido \\
\hline $\begin{array}{l}\text { Fortaleza } \\
\text { CE }\end{array}$ & Agosto de 98 & 1997 & Projeto em atividade \\
\hline $\begin{array}{l}\text { Sobral } \\
\text { CE }\end{array}$ & Agosto de 98 & 1997 & Projeto em Atividade \\
\hline $\begin{array}{l}\text { Crateús } \\
\text { CE }\end{array}$ & Agosto de 98 & 1997 & Projeto em Atividade \\
\hline $\begin{array}{l}\text { Anadia } \\
\text { AL }\end{array}$ & Agosto de 98 & 1997 & Projeto em Atividade \\
\hline $\begin{array}{c}\text { Arapiraca } \\
\text { AL }\end{array}$ & Agosto de 98 & 1997 & Projeto em Atividade \\
\hline $\begin{array}{c}\text { Flexeiras } \\
\text { AL }\end{array}$ & Agosto de 98 & 1997 & Projeto em Atividade \\
\hline $\begin{array}{c}\text { Maceió } \\
\text { AL }\end{array}$ & Agosto de 98 & 1995 & Projeto em Atividade \\
\hline $\begin{array}{l}\text { Dionísio } \\
\text { MG }\end{array}$ & Agosto de 98 & 1996 & Projeto em Atividade \\
\hline $\begin{array}{c}\text { São José do Goiabal } \\
\text { MG }\end{array}$ & Agosto de 98 & 1996 & Projeto em Atividade \\
\hline \multicolumn{2}{|c|}{ TOTAL: 20 CIDADES } & \multicolumn{2}{|c|}{ PERÍODO: JUL. a SET / 98.} \\
\hline
\end{tabular}

Das 16 cidades inicialmente apontadas como partícipes do movimento por Cidades/Municípios Saudáveis, 5 tiveram seus processos interrompidos devido a 
Cidades Saudáveis no Brasil e os processos participativos: os casos de Jundiaí e Maceió

mudanças administrativas: São Paulo, Santos e Campinas, no Estado de São Paulo; Palmeira, no Paraná e Iraquara, na Bahia; 2 delas desenvolveram algumas atividades de sensibilização e não chegaram efetivamente a implantar ações: Diadema, no Estado de São Paulo e Ceú Azul, no Paraná.

Dar continuidade aos projetos é um problema difícil de ser equacionado. Os fatores que dificultam o desenvolvimento e a continuidade de iniciativas por Cidades Saudáveis, no Brasil, foram descritos por FERRAZ (1999): a herança de uma cultura política de ação setorial, que produz competição entre os diferentes setores e dificulta qualquer tentativa de mudança da lógica de administrar; instabilidade política decorrente da falta de maturidade para o exercício da democracia, fazendo com que haja mudanças radicais a cada novo governo, que impedem a continuidade de ação e projetos; dificuldade de apoio logístico para a execução dos projetos, já que o ideário por Cidades Saudáveis é pouco difundido entre os profissionais de saúde e gerentes; e, finalmente, a cultura sanitária dos programas verticais, que historicamente foram implementados com vistas a controlar doenças. Assim, há de se alterar e reorganizar os modelos de intervenção, valorizando a Promoção da Saúde e o estabelecimento de políticas públicas saudáveis.

A mudança administrativa de 1996 foi um marco para a maioria dessas cidades. Com a mudança dos prefeitos, as iniciativas foram se enfraquecendo e acabaram esquecidas. As eleições de 1996 foram também uma importante referência para aquelas cidades que iniciaram seus projetos. Até o ano de 1998, 13 cidades foram identificadas como partícipes deste movimento no Brasil, conforme se pode observar na figura 2, sendo 9 cidades incluídas após o ano eleitoral de 1996: Jundiaí e Vargem Grande Paulista, no Estado de São Paulo; Maceió, Anadia, Arapiraca e Flexeiras, em Alagoas; Fortaleza, Crateús e Sobral, no Ceará; São José do Goiabal e Dionísio, em Minas Gerais, Curitiba e Chopinzinho, no Paraná. 


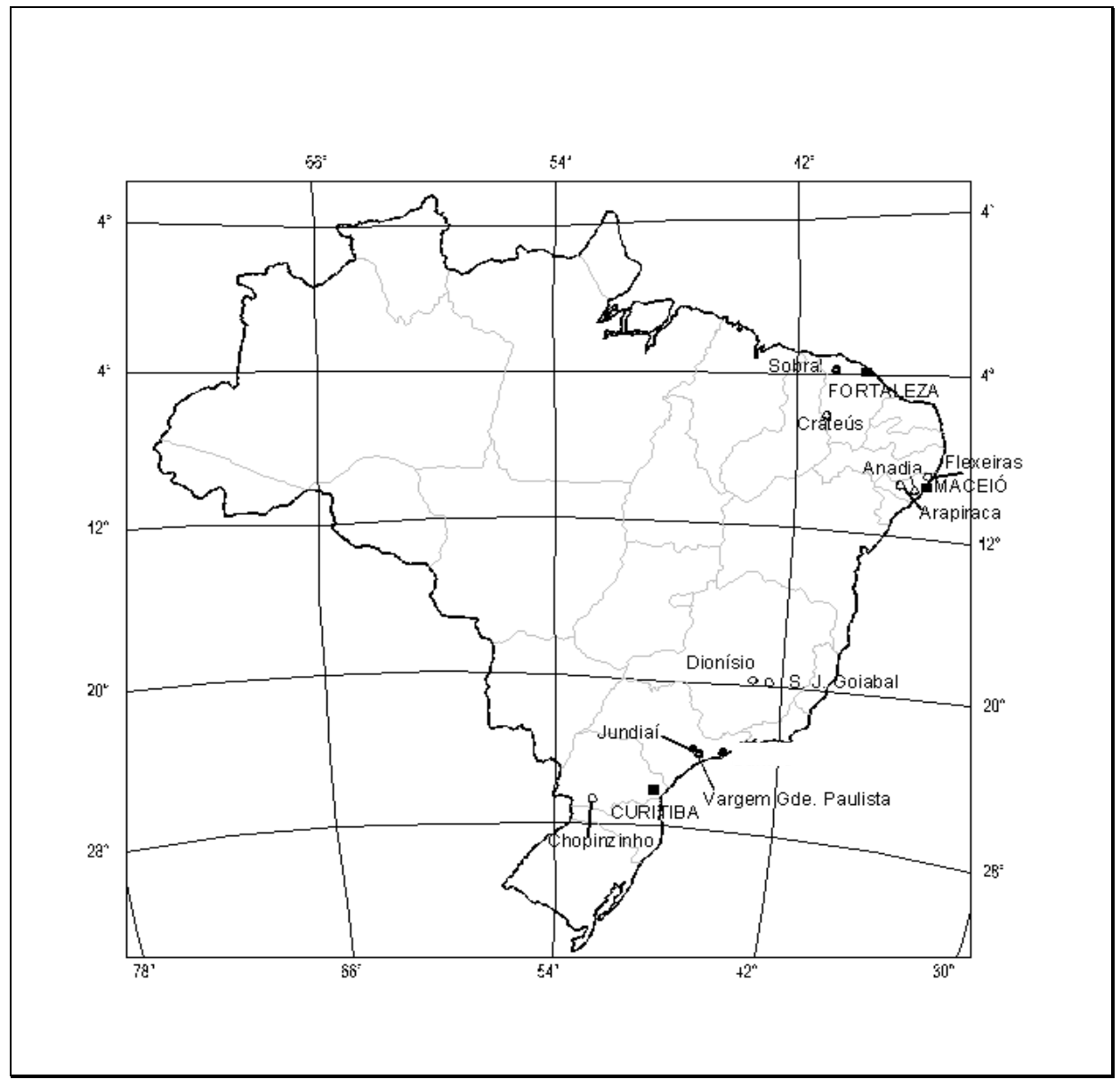

Figura 2 - Distribuição dos Projetos Cidades Saudáveis no Brasil em 1998.

Por que as cidades decidiram aderir ao movimento por Cidades Saudáveis?

De acordo com os depoimentos pode-se considerar que tem havido duas principais motivações para que uma gestão municipal se aproxime deste movimento. Uma delas é a cidade, de certa forma, já ter assumido como prioridade o desenvolvimento de políticas públicas integradas, ter se disposto a desenvolver diversas iniciativas intersetoriais e ter promovido e incentivado a participação da população. Outra motivação tem relação com a busca de outras formas de gestão municipal, que não as compartimentadas e setorizadas, e que respondam à saúde como qualidade de vida. Como se percebe, essas duas questões não se excluem, estão intimamente relacionadas e assentam-se, sobretudo, na redefinição de uma política de gestão local coordenada, que articule as instâncias governamentais com as da sociedade civil. 
É certo que essas motivações têm relação com o que BUSS (2000) considera uma perspectiva de adoção de políticas públicas saudáveis. Há necessidade de se adotar uma perspectiva global para a análise da questão da saúde e não somente do setor saúde, incorporando os conhecimentos sobre as outras áreas de políticas públicas. Operar nessa nova lógica significa, contudo, configurar uma autoridade social ou conjunto dos responsáveis pelas políticas públicas que coordene os arranjos institucionais em tornos de planos e projetos.

Estas questões aparecem no depoimento de um dos técnicos entrevistados, no qual fica clara a vinculação da motivação em aderir a uma proposta que tenha uma dimensão de uma política para a cidade:

"Na verdade, a gente tava sempre muito a busca de uma proposta que pudesse romper essa coisa do setorial, esse trabalho da área da saúde... o conceito de Cidade Saudável veio nos ajudar, porque deu essa dimensão de que é uma proposta de Governo e não é uma proposta de setor. Tem que ser assumida pelo prefeito, pela Secretaria de Governo, pelo gabinete do prefeito, pelos vereadores, quer dizer, uma proposta de gestão pública... a busca da proposta era justamente para conseguir dar esse passo para frente, você conseguir trabalhar mais na área da promoção, da prevenção."

O que se observa é que o setor da saúde é o articulador do projeto na cidade e responsável pela fase de disseminação do ideário por Cidades Saudáveis. De acordo com FERRAZ (1999), o protagonismo do setor saúde é um dos fatores que facilitam a introdução desse movimento no país. O movimento pela saúde no país, o movimento sanitário, como atesta a autora, está entre os movimento sociais mais articulados em defesa da democratização da sociedade brasileira e da saúde como direito de cidadania e, por isso, ocupa, no contexto sociopolítico, um lugar fundamental, agindo como ator político e social na cena política de saúde, contribuindo com mudanças paradigmáticas, legislativas e administrativas.

Um técnico da cidade de Diadema explica porque a área de saúde de sua cidade se mobiliza em torno de projetos que relacionem as questões de saúde às de qualidade de vida : 
Cidades Saudáveis no Brasil e os processos participativos: os casos de Jundiaí e Maceió

\begin{abstract}
"Eu acho que, em parte, havia uma certa sensação da ineficiência do trabalho desenvolvido com saúde, no sentido de melhorar a qualidade de vida. Havia um modelo que atendia muitas pessoas, produzia muitas consultas, muitos atendimentos, tinha um reconhecimento bastante considerável da população nesse sentido, mas centralizado na assistência individual, assistência médica e muito poucas atividades de grupo ou outras atividades, e quase nada de articulação intersetorial, com algumas exceções" (Diadema 1998).
\end{abstract}

Esta justificativa é reafirmada por técnicos de outras cidades, que entendem que é necessário, num primeiro momento, mobilizar os diferentes segmentos da sociedade civil para a proposta, com a realização de seminários de sensibilização, envolvimento de diferentes níveis de governo, com o intento de realizar, numa etapa seguinte, o planejamento integrado com desenvolvimento de ações que envolvem mobilização conjunta de esforços e recursos.

O fato de o setor da saúde impulsionar essas atividades faz com que os projetos dêem maior visibilidade ao setor da saúde. Esses processos são discutidos com maior intensidade no âmbito dos Conselhos de Saúde, que tradicionalmente têm representatividade de diversos segmentos da população e possuem uma prática política consolidada nos últimos 20 anos, focalizando as discussões em torno da saúde como direito fundamental do cidadão. Além disso, muitos dos atores políticos, secretários da saúde e prefeitos, são pessoas, que nos últimos anos, empenharam-se na definição e estruturação dos processos de municipalização e de descentralização no campo da saúde pública, e mostram particular interesse na proposta por Cidades Saudáveis e na possibilidade de adotar essa estratégia como política de governo. Uma técnica da cidade de Arapiraca, Estado de Alagoas, diz:

“... a própria prefeita, por ser médica
sanitarista, ela tem uma compreensão do
processo saúde e doença muito claro. Ela já
entendia que trabalhar o setor saúde sozinha
ela não ia conseguir resolver os problemas de
saúde. Ela fez então junto com o grupo
técnico um programa para assumir na
administração dela e já nesse plano


Cidades Saudáveis no Brasil e os processos participativos: os casos de Jundiaí e Maceió

$$
\begin{aligned}
& \text { sinalizava como trabalhar outros setores para } \\
& \text { intervir nas condições de vida da } \\
& \text { população..." (Arapiraca 1998). }
\end{aligned}
$$

Construir, no interior de um governo local, a marca Cidade Saudável, não é uma questão fácil de ser equacionada, já que, muitas vezes, o adjetivo saudável é tido como estando relacionado apenas à saúde, e que gera dificuldades com outras secretarias de governo. Alguns depoimentos relatam a concorrência entre as diferentes áreas de governo e sugerem que esses projetos dão maior poder ao setor da saúde. Reafirmam, no entanto, a necessidade de que os projetos Cidades Saudáveis sejam articulados com outras forças políticas e com outras instâncias de controle social. A esse respeito, diz um técnico da cidade de Diadema/SP:

"Agora eu acredito que, em geral, a saúde é a grande porta para esse tipo de Projeto, porque ela é a secretaria que lida com os limites de vida e morte, com epidemiologia, com as bases, até para medir, para acompanhar o processo de mudança de qualidade de vida, mas é imprescindivel que, desde o princípio, isso esteja amarrado com outras autoridades políticas, com outras forças políticas e com a população, enfim, com setores fortes de outras áreas que compreendam a dimensão desse processo. Sem esse tipo de aliança, o risco é que a saúde termine disparando mais concorrências ou invejas ou, enfim, mais discenso do que consenso, porque o projeto, de certo modo, suscita, sugere o poder da saúde maior talvez do que seja necessário, do que seja conveniente, quando se quer uma articulação, que demanda muito mais abrir mão de poder do que concentrar poder" (Diadema 1998).

BUSS (2000) chama a atenção para o poder do setor da saúde diante dos outros setores no estabelecimento de políticas públicas saudáveis. É importante evitar a subordinação de outros setores governamentais à esfera da saúde, para não gerar resistências e suscitar isolamentos. Na definição de políticas públicas saudáveis, o autor recomenda o estabelecimento de pactos horizontais com parceiros governamentais e de outras instâncias. Isto significa ter a intersetorialidade como sua principal estratégia. 
Cidades Saudáveis no Brasil e os processos participativos: os casos de Jundiaí e Maceió

Nesse sentido, estariam esses projetos se desenvolvendo intersetorialmente?

Pode-se dizer que algumas cidades têm tido a preocupação inicial de adotar uma lógica intersetorial de organização e atuação, mas esse percurso é difícil, se considerarmos que o setor da saúde é referido como aquele que tem maior possibilidade de ganhos com essa iniciativa. O início do projeto, na cidade de São Paulo, atesta isso. A definição política de desenvolver um projeto na região central da cidade fez com que se viabilizasse a constituição de um Governo Local Intersetorial, responsável pelas ações conjuntas inter-governamentais em diversos programas estabelecidos pela prefeitura, como por exemplo, o de cólera; o dirigido à população moradora de rua, projetos de re-urbanização do centro da cidade.

Técnicos avaliam, no entanto, que é justamente no plano intra-setorial que o trabalho fluiu melhor. O setor da saúde, especialmente os Distritos de Saúde, possuíam um plano de trabalho cuja marca era Centro Saudável. A partir daí, suas políticas e os vários projetos de intervenção foram criados, sendo enfatizados aqueles que reorganizaram os serviços de saúde na região, como a criação de um Centro de Referência de Saúde do Trabalhador, a instalação de uma Unidade Básica de Saúde, municipalização de serviços de vigilância à saúde.

Na maioria das cidades, observa-se, que a lógica de trabalho predominante é a prática institucional dicotômica. As ações são setoriais e muitos dos trabalhos chamados intersetoriais são, na verdade, desenvolvidos integradamente. Os setores da saúde, da educação e da ação social parecem ser os parceiros mais comuns. Muitas dessas iniciativas são informais, especialmente em municípios de pequeno porte, não envolvendo um trabalho prévio de planejamento. A integração se dá por projetos específicos que são definidos por um determinado setor.

Como consideram JUNQUEIRA e INOJOSA (1997), implantar a intersetorialidade requer decisão política, pois implica mudanças na organização municipal, ou seja, nas estruturas de poder. Essa nova lógica não se refere, entretanto, apenas ao arranjo institucional interno das administrações. Essa lógica é referida à população. Deve dar respostas integradas aos problemas identificados pelos indivíduos e grupos da população, sujeitos do processo de definição de prioridades. Por isso são necessárias negociações entre os diferentes atores sociais 
Cidades Saudáveis no Brasil e os processos participativos: os casos de Jundiaí e Maceió

presentes na arena política, que devem ser sensibilizados e comprometidos com a mudança.

A respeito do forte protagonismo do setor da saúde, recomenda a Organização Pan-Americana de Saúde (OPS 1999a, p.28,29): a ação intersetorial demanda da área de saúde não somente iniciativa, mas sobretudo receptividade. É necessário responder a convocatórias de outros setores elou contribuir na ação de instâncias de ação intersetorial, onde se abordem os problemas da população através de ações que sejam baseadas em um pensamento intersetorial, se obtenha uma coordenação intersetorial para concretizar projetos intersetoriais."

Como as cidades vêm desenvolvendo as ações?

Para FERRAZ (1999), a proposta de desenvolvimento de projetos pela Organização Mundial de Saúde é bastante geral e não leva em consideração as limitações de ordem política, cultural ou estrutural a que estão submetidos os países em desenvolvimento. A Organização Pan-Americana de Saúde tem recomendado que no desenvolvimento de projetos Cidades/Municípios Saudáveis, nos países da região das Américas, sejam considerados três estágios básicos: inicial, de planejamento e de consolidação, definidos em 20 passos.

A primeira fase focaliza o processo inicial, por meio da construção de um suporte público e da criação de consciência, sendo importante, nesta etapa, o envolvimento de vários grupos locais e setores. Nesta etapa, deverá ser constituído um Comitê Intersetorial de Planejamento e estabelecido o compromisso das autoridades locais em construir uma cidade/município saudável. Durante a segunda fase, são formalizados a organização institucional do projeto, a preparação de projetos específicos e o estabelecimento de um sistema de informação, de supervisão e avaliação. Nesta fase, é também produzido o Plano Cidade Saudável. Finalmente, a terceira e última fase é destinada à consolidação do plano, que inclui avaliação das atividades e o estabelecimento de redes com outras Cidades Saudáveis (OPS 1997).

A tabela 4 a seguir mostra essas fases e seus respectivos passos. 
Cidades Saudáveis no Brasil e os processos participativos: os casos de Jundiaí e Maceió

Tabela 4 - Fases do desenvolvimento de Cidades/Municípios Saudáveis nas Américas

Fase 1 - Início

- Realizar reuniões entre as autoridades locais e os líderes comunitários

- Estabelecer o compromisso do governo local

- Estabelecer o Comitê Intersetorial

- Realizar a análise participativa dos problemas a partir das necessidades da comunidade e município

- Determinar as prioridades de ação

Fase 2 - Planejamento

- Capacitar os envolvidos em Promoção da Saúde, metodologias participativas, avaliação e outros.

- Elaborar um plano de ação

- Preparar projetos específicos

- Mobilizar recursos

- Estabelecer sistemas de informação, supervisão e avaliação

Fase 3 - Consolidação

- Desenvolver as atividades estabelecidas

- Criar escolas promotoras da saúde, ambientes saudáveis e outros

- Sistematizar, monitorar e avaliar as experiências

- Estabelecer trabalhos em redes para apoio e troca de experiências

Fonte: Municipios Saludables (OPS 1997)

Uma revisão dos projetos brasileiros indica que as cidades iniciam seus processos seguindo alguns desses passos. As experiências apresentam um estágio de desenvolvimento inicial bastante intenso. Os processos se iniciam logo após as autoridades locais, terem discutido ou tomado conhecimento, através de um ou mais setores, dos conceitos que fundamentam os projetos Cidades Saudáveis. No geral adotam slogans que mostram que as ações vão estar prioritariamente relacionadas à qualidade de vida da população, o que tem uma grande aceitação popular. É inquestionável enquanto valor. Difícil encontrar oposição, até mesmo entre os opositores de governo. É o caso de diversas cidades no Brasil: Jundiaí Saudável, Santos Saudável, Campinas Saudável, São Paulo Saudável, entre outras.

O que se verifica é que as cidades brasileiras atingiram diferentes estágios no desenvolvimento dos projetos. Poucas chegaram a criar comitês intersetoriais, previstos na Fase 1, e um número muito pequeno avançou nas Fase 2 e 3 de elaboração de um plano para a cidade, que deveria envolver os diversos setores de governo e parceiros, bem como a implementação, o monitoramento e a avaliação das ações. A tabela 5 mostra o resumo das ações realizadas nas cidades e suas respectivas fases. 
Cidades Saudáveis no Brasil e os processos participativos: os casos de Jundiaí e Maceió

Tabela 5- Quadro resumo das ações realizadas nos Projetos Cidades Saudáveis no Brasil e suas respectivas fases.

\begin{tabular}{|c|c|c|c|}
\hline CIDADE & INÍCIO & AÇÕES REALIZADAS & FASES \\
\hline $\begin{array}{l}\text { São Paulo } \\
\text { SP }\end{array}$ & 1991 & $\begin{array}{ll}\text { - } & \text { Seminário "Cidades Saudáveis" } \\
\text { - } & \text { Realização da III Conferência Municipal de Saúde: "São } \\
& \text { Paulo Saudável: desafio e compromisso"(1992) } \\
\text { - } & \text { Programa “Centro Saudável” } \\
\text { - } & \text { Projetos específicos: resgate/remoção, vigilância à saúde }\end{array}$ & $\begin{array}{l}\text { Fase } 2 \\
\text { Fase } 3\end{array}$ \\
\hline $\begin{array}{c}\text { Diadema } \\
\text { SP }\end{array}$ & 1994 & $\begin{array}{l}\text { - } \quad \text { Realização do encontro Municipal: “Diadema, Cidade } \\
\text { - } \quad \text { Reaudável rumo ao ano 2000” } \\
\text { - }\end{array}$ & Fase 1 \\
\hline $\begin{array}{l}\text { Campinas } \\
\text { SP }\end{array}$ & 1994 & $\begin{array}{l}\text { - } \quad \text { Criação do Conselho Comunidade Solidária de Campinas } \\
\text { - Sede do I Congresso Latino Americano para Cidades e } \\
\text { - } \quad \text { Pomunidades Saudáveis (1996) } \\
\text { - } \quad \text { Investimenta e implantação de um novo modelo de gestão: } \\
\text { - } \quad \text { Desenvolvimento de projetos de enfoque intersetorial }\end{array}$ & $\begin{array}{l}\text { Fase } 2 \\
\text { Fase } 3\end{array}$ \\
\hline $\begin{array}{c}\text { Jundiaí } \\
\text { SP }\end{array}$ & 1994 & $\begin{array}{ll}\text { - } & \text { Seminário de sensibilização } \\
\text { - } & \text { Criação do Comitê Cidade saudável } \\
\text { - } & \text { Fortalecimento do controle social e parcerias } \\
\text { - } & \text { Ampliação de projetos que já vinham sendo realizados } \\
\text { - } & \text { Concursos envoriversificação da participação do bairro } \\
\end{array}$ & $\begin{array}{l}\text { Fase } 1 \\
\text { Fase } 2 \\
\text { Fase } 3\end{array}$ \\
\hline $\begin{array}{l}\text { Santos } \\
\text { SP }\end{array}$ & 1994 & $\begin{array}{l}\text { IV Conferência Municipal de Saúde (3000 participantes) } \\
\text { incorpora a filosofia de Cidade Saudável } \\
\text { Ações diversas de educação ambiental, na área de saúde, } \\
\text { dos transportes. }\end{array}$ & $\begin{array}{l}\text { Fase } 1 \\
\text { Fase } 3\end{array}$ \\
\hline $\begin{array}{l}\text { Vargem } \\
\text { Grande } \\
\text { Paulista } \\
\quad \text { SP }\end{array}$ & 1997 & $\begin{array}{l}\text { - } \begin{array}{l}\text { Discussão inicial envolvendo escolas, serviços de saúde, } \\
\text { administração municipal e universidade. }\end{array} \\
\text { - Fórum sobre Municípios Saudáveis (x Municípios da } \\
\text { Grande São Paulo) } \\
\text { Projeto de educação ambiental e educação em saúde nas } \\
\text { escolas municipais }\end{array}$ & Fase 3 \\
\hline $\begin{array}{c}\text { Iraquara } \\
\text { BA }\end{array}$ & 1994 & $\begin{array}{l}\text { - Circulação de informações por meios formais e informais } \\
\text { de comunicação } \\
\text { - } \\
\text { Identificação da realidade e de projetos com perspectivas } \\
\text { - } \quad \text { Envolvins } \\
\end{array}$ & \begin{tabular}{|l} 
Fase 1 \\
Fase 2
\end{tabular} \\
\hline $\begin{array}{c}\text { Céu Azul } \\
\text { PR }\end{array}$ & 1995 & - Discussão do ideário no Conselho Municipal de Saúde & Fase 1 \\
\hline $\begin{array}{c}\text { Chopinzinho } \\
\text { PR }\end{array}$ & 1995 & $\begin{array}{ll}\text { - } & \text { Pesquisa de opinião pública para ouvir a população } \\
\text { - } & \text { Trabalho intersetorial (“Secretariado em sintonia”) } \\
\text { - } & \text { Utilização dos meios de comunicação local-rádio } \\
\text { - } & \text { Levantamento do problemas por bairro } \\
\text { - } & \text { Plano de desenvolvimento de Recursos Humanos para } \\
\text { - } & \text { Pervidores públicos } \\
\text { - } & \text { Desenvolvicipação de entidades nas decisões políticas } \\
\end{array}$ & Fase 2 \\
\hline $\begin{array}{c}\text { Curitiba } \\
\text { PR }\end{array}$ & 1994 & $\begin{array}{ll}\text { - } & \text { Planejamento intersetorial } \\
\text { - } & \text { Projeto Cidadão Saudável } \\
\text { vida }\end{array}$ & $\begin{array}{l}\text { Fase } 1 \\
\text { Fase } 2 \\
\text { Fase } 3\end{array}$ \\
\hline
\end{tabular}


Cidades Saudáveis no Brasil e os processos participativos: os casos de Jundiaí e Maceió

\begin{tabular}{|c|c|c|c|}
\hline $\begin{array}{c}\text { Palmeira } \\
\text { PR }\end{array}$ & 1995 & $\begin{array}{ll}\text { - } & \text { Injeção de recursos na assistência básica à população (fase } \\
& \text { reparadora) } \\
\text { - } & \text { Planejamento de ações intersetoriais } \\
\text { - } & \text { Formação do Conselho Comunitário- Comitê Cidade para } \\
\text { - } & \text { a Saúde } \\
\text { - } & \text { Definição de prioridades } \\
& \text { Desenvolvimento de projetos }\end{array}$ & $\begin{array}{l}\text { Fase } 2 \\
\text { Fase } 3\end{array}$ \\
\hline $\begin{array}{l}\text { Fortaleza } \\
\text { CE }\end{array}$ & 1997 & $\begin{array}{ll}\text { - } & \text { Definição de uma gestão descentralizada e intersetorial } \\
\text { - } & \text { Criação de Secretarias Executivas Regionais, } 2 \text { secretarias } \\
\text { - } & \text { de suporte técnico e outra de Ação Governa-mental } \\
\text { - } & \text { Desenvolvimento de Projetos }\end{array}$ & $\begin{array}{l}\text { Fase } 1 \\
\text { Fase } 2 \\
\text { Fase3 }\end{array}$ \\
\hline $\begin{array}{c}\text { Crateús } \\
\text { CE }\end{array}$ & 1997 & $\begin{array}{ll}\text { - } & \text { Realização de } 26 \text { conferências para discussão da proposta } \\
\text { - } & \text { Diagnóstico de realidade } \\
\text { - } & \text { Formalização de comitês locais } \\
\text { - } & \text { Desenvalva de problemas e definição de encaminhamentos } \\
& \end{array}$ & $\begin{array}{l}\text { Fase } 1 \\
\text { Fase } 2 \\
\text { Fase } 3\end{array}$ \\
\hline $\begin{array}{c}\text { Sobral } \\
\text { CE }\end{array}$ & 1997 & $\begin{array}{l}\text { - Projeto de Desenvolvimento Local Integrado: Município } \\
\text { Saudável - Escolas Promotoras de Municípios Saudáveis" } \\
\text { - Desenvolvimento de projetos com enfoque intersetorial }\end{array}$ & $\begin{array}{l}\text { Fase } 1 \\
\text { Fase } 2 \\
\text { Fase } 3\end{array}$ \\
\hline $\begin{array}{c}\text { Maceió } \\
\text { AL }\end{array}$ & 1995 & $\begin{array}{l}\text { - Definição do projeto Comunidades Saudáveis em duas } \\
\text { - } \quad \text { Investigação de realidade } \\
\text { - } \quad \text { Discussão de dados com a população }\end{array}$ & $\begin{array}{l}\text { Fase } 1 \\
\text { Fase } 2\end{array}$ \\
\hline $\begin{array}{c}\text { Anadia } \\
\text { AL }\end{array}$ & 1997 & 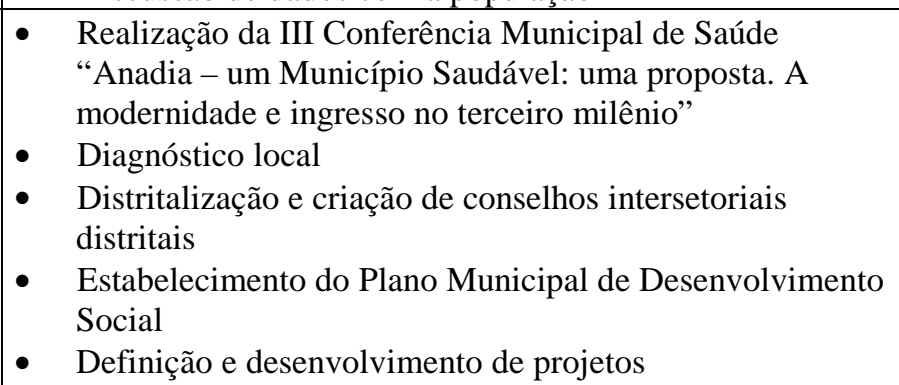 & $\begin{array}{l}\text { Fase } 2 \\
\text { Fase } 3\end{array}$ \\
\hline $\begin{array}{c}\text { Arapiraca } \\
\text { AL }\end{array}$ & 1997 & - $\quad$ Desenvolvimento de projetos com enfoque intersetorial & Fase 2 \\
\hline $\begin{array}{c}\text { Flexeiras } \\
\text { AL }\end{array}$ & 1997 & $\begin{array}{ll}\text { - } & \text { Discussão com o Conselho Municipal de Saúde } \\
\text { - } & \text { Realização da II Conferência Municipal de Saúde: } \\
& \text { Flexeiras.passo a passo para se tornar um município } \\
& \text { saudável } \\
\text { - } & \text { Desenvolvimento de projetos com enfoque intersetorial }\end{array}$ & $\begin{array}{l}\text { Fase } 1 \\
\text { Fase } 3\end{array}$ \\
\hline $\begin{array}{c}\text { Dionísio } \\
\text { MG }\end{array}$ & 1996 & $\begin{array}{ll}\text { - } & \text { Diagnóstico da situação atual do município } \\
\text { - } & \text { Análise e priorização de problemas } \\
\text { - } & \text { Seminários visando discussão de propostas } \\
\text { - } & \text { Formação de Grupos Intersetorial }\end{array}$ & $\begin{array}{l}\text { Fase } 1 \\
\text { Fase } 2\end{array}$ \\
\hline $\begin{array}{l}\text { São José do } \\
\text { Goiabal } \\
\text { MG }\end{array}$ & 1996 & $\begin{array}{ll}\text { - } & \text { Diagnóstico da situação atual do município } \\
\text { - } & \text { Análise e priorização de problemas } \\
\text { - } & \text { Deminários visando discussão de propostas } \\
\text { - } & \text { Formação de Grojetos } \\
\end{array}$ & $\begin{array}{l}\text { Fase } 1 \\
\text { Fase } 2\end{array}$ \\
\hline
\end{tabular}

Fonte: Publicações selecionadas e colhidas nas visitas às cidades, e nas entrevistas da Estimativa Rápida

É difícil definir com exatidão em que fases do Projeto as cidades se encontram. A maioria das cidades realizaram algumas atividades referidas nas Fases 
Cidades Saudáveis no Brasil e os processos participativos: os casos de Jundiaí e Maceió

1, 2 e 3 da tabela 4- Fases de desenvolvimento das Cidades/Municípios Saudáveis nas Américas. Pode-se afirmar que a tendência é incluir atividades que a cidade já vinha desenvolvendo antes do estabelecimento do Projeto Cidades Saudáveis. Isso significa que a Fase 2, de planejamento, da elaboração de um plano, do estabelecimento de sistemas, de supervisão, e de avaliação, acaba não sendo realizada.

Quem são os parceiros?

O que tem sido observado, também, é que cada novo governo imprime sua marca. Dar continuidade à filosofia adotada pelo governo anterior, mesmo sendo do mesmo partido político, parece ter um significado de que nada de novo vai ser realizado. E é preciso realizar coisas "novas". Como as políticas públicas, em geral, não são assumidas por toda a sociedade e se caracterizam como projetos de governo, a alternância de poder não permite que os projetos se sustentem.

Mesmo as cidades que tiveram uma aproximação com o ideário de Cidades Saudáveis, incentivadas pelo governo estadual, como é o caso do Paraná, não garantiram a continuidade dos projetos. O mesmo ocorreu com a cidade de Campinas, onde o projeto Cidades Saudáveis promoveu significativas mudanças políticas, mas não conseguiu sobreviver no interior da própria administração, do mesmo partido político, quando o prefeito em 1996, entusiasta do ideário, faleceu antes de terminar sua gestão. Hoje, em São Paulo, após 8 anos de interrupção do projeto, o conceito de "Cidade Saudável é descolado da realidade do município e da própria prática do município”, como afirma o ex- secretário da saúde que foi um defensor do projeto na cidade.

Recente pesquisa realizada pela Organização Pan-Americana de Saúde mostra, entretanto, o contrário. Os conceitos de Cidades Saudáveis têm sido adotados em várias cidades, em diversos países do mundo, por políticos que representam diversas afiliações políticas e ideológicas, e o progresso do movimento não tem sido afetado pelas mudanças governamentais. A maior garantia de estabilidade e sustentabilidade dos projetos tem sido a participação ativa de membros da comunidade, empresas locais e diferentes setores municipais (PAHO 1999). 
Cidades Saudáveis no Brasil e os processos participativos: os casos de Jundiaí e Maceió

FARAH (1999) tem sustentado a idéia de que a construção de novos arranjos institucionais só se completa com o estabelecimento de parcerias entre Estado e a sociedade civil. Para a autora, a promoção de ações integradas, focalizando-se uma área de intervenção e articulando ações tradicionalmente fragmentadas nos diversos campos sociais apontam para a construção de redes, crescendo a possibilidade de enraizamento das políticas públicas.

No caso dos projetos brasileiros Cidades/Municípios Saudáveis, as parcerias não têm sido ampliadas. As mais referidas são órgãos da própria administração municipal, seguida da sociedade civil organizada e das universidades. De fato, algumas experiências têm mostrado que as cidades procuram seus próprios parceiros, e se isso, de um lado, é positivo, no sentido de que as localidades buscam ir ao encontro a suas necessidades, de acordo com suas possibilidades, por outro, perde-se a oportunidade da troca de experiências exitosas, que poderiam contribuir para consolidar um movimento mais amplo. Tem-se discutido a formação de uma rede brasileira de Cidades/Municípios Saudáveis há alguns anos. Hoje, o Ministério da Saúde, através da Secretaria de Políticas Públicas, juntamente com a OPAS, CONASEMS, universidades e as cidades já integrantes do movimento têm reunido esforços para consolidar a iniciativa no país.

As universidades são parceiras na maioria dos projetos que vêm sendo desenvolvidos (Anexo 6). Em realidade, o campo da Promoção da Saúde vem se ampliando, como linha de ensino e pesquisa em universidades que vêm discutindo o paradigma da produção social da saúde, e investindo em projetos que podem se desenvolver na perspectiva de construir novas práticas de ensino de saúde pública. Além disso, algumas delas têm programas de cooperação e apoio aos municípios no processo de descentralização e municipalização das ações de saúde, desde a implantação do Sistema Único de Saúde, o que acabou criando um vínculo forte entre a universidade e os municípios. Uma professora da Universidade Federal de Alagoas afirma:

“... historicamente o Estado de Alagoas e a Secretaria Estadual sempre tutelaram as ações de saúde... o Estado era quem assumia tudo em termos de assistência-saúde e aí a gente passou uns três a quatro anos 
Cidades Saudáveis no Brasil e os processos participativos: os casos de Jundiaí e Maceió

desenvolvendo esse programa, apoiando

grupo de municípios a montarem suas secretarias, seus conselhos de saúde, fazerem suas conferências ..." (Maceió 1998).

O apoio técnico e metodológico das universidades é referido como fundamental pelos técnicos dos municípios. As universidades entendem que este seu papel é importante e reforçam a idéia de que devem contribuir no processo, para que os atores envolvidos se apropriem de conceitos e metodologias de trabalho. Diz um professor da Escola de Saúde Pública de Minas Gerais:

“... nós somos o grupo assessor, que foi, de
alguma forma, levar para eles essa forma de
fazer cidades saudáveis. Trabalhamos com
eles os conceitos de cidades saudáveis, e aí
nós começamos trabalhando para ajudar a
fazer um diagnóstico, pensar uma
priorização, a pensar os projetos,... a gente
tem uma preocupação tremenda com essa
dimensão pedagógica, temos a intenção de
não fazer para eles, a nossa intenção é de
fazer com eles, então a idéia nossa é de que
eles aprendam de alguma forma, que eles se
apropriem ...” ( Dionísio e São José do
Goiabal 1998).

Nota-se nesse depoimento, uma nítida preocupação com o processo de desenvolvimento e com a continuidade dos projetos. Neste caso específico, a Escola de Saúde Pública de Minas Gerais tem um importante papel indutor do ideário nas cidades onde atua, oferecendo suporte aos aspectos relacionados à implementação das ações e os aportes metodológicos necessários. Seus técnicos atuam como interlocutores políticos, buscando viabilizar econômica e politicamente os apoios necessários à estruturação do projetos nas cidades. Uma questão relevante, mas ainda não muito bem equacionada é a preocupação de que esses processos não sejam tutelados e que as cidades venham a ser autônomas, podendo construir suas próprias soluções para o desenvolvimento social. O depoimento de uma das coordenadoras do grupo técnico de São José do Goiabal expressa os receios em relação a um possível desligamento da Escola de Minas Gerais:

“...nós não estamos preparadas ainda para ficar sozinhas nesse barco. Embora a gente ache que tem que aprender porque já são dois 
Cidades Saudáveis no Brasil e os processos participativos: os casos de Jundiaí e Maceió

anos, a gente tem que aprender a andar com as próprias pernas, eu ainda tenho medo de que eles se afastando essa corrente se quebre" (São José do Goiabal 1998).

Como vem se dando o acompanhamento dos projetos?

Elaborar uma metodologia que permita avaliar o processo de desenvolvimento dos projetos Cidades/Municípios Saudáveis implica reconhecer diversos fatores e acordar múltiplas concepções. O desafio está colocado aos projetos que vêm se dando no mundo inteiro: como avaliar essa estratégia em termos de processo e mesmo dos resultados a que se propõem?

Já há alguns anos, tem-se colocado a necessidade de avaliar programas e atividades de Promoção da Saúde. Esta é uma questão complexa, uma vez que o marco conceitual e metodológico da avaliação deve reconhecer a saúde como qualidade de vida e, portanto, a complexidade de seu enfoque de atuação sobre os determinantes sociais de saúde. Em conseqüência, a avaliação de Cidades Saudáveis deve refletir os aspectos fundamentais da Promoção da Saúde, tais como alcançar a eqüidade, a participação social, a intersetorialidade para obtenção de melhor qualidade de vida (OPS 1999a). A pesquisa desenvolvida por Marleen Goumans (1997), sobre Cidades Saudáveis na Holanda e Inglaterra, discute a dificuldade de avaliar esses projetos, dada a impossibilidade de isolar variáveis no contexto dos projetos, por isso, não é fácil mostrar a contribuição específica das Cidades Saudáveis.

No II Congresso de Municípios Saudáveis realizado em Veracruz, no México, em 1997, onde se conformou a Rede Latinoamericana, colocou-se a necessidade de preparação de uma proposta de avaliação para o movimento Municípios Saudáveis na América Latina, que começou a ser esboçada no Taller de Evaluación de Municípios Saludables, ocorrido em agosto de 1999, em Washington (DC). Neste encontro, que contou com a participação de 15 países da América Latina e Caribe, inclusive o Brasil, chegou-se a identificar 4 elementos fundamentais de avaliação para esses projetos: ser congruente com os princípios de desenvolvimento humano e social sustentável; ser participativo para fortalecer a capacidade da população e das organizações; ser formativo e, finalmente, adotar métodos mistos, quantitativos e 
qualitativos. Algumas experiências devem ser adotadas pelos países, que irão avaliar seus projetos em 4 aspectos: políticas públicas, participação social, intersetorialidade e sustentabilidade (OPS 1999b; OPS 1999c).

Com o objetivo de estabelecer um monitoramento contínuo de um processo intersetorial de qualidade de vida, AKERMAN (1995), propõe a utilização de indicadores compostos ${ }^{17}$ para projetos Cidades Saudáveis. Essa experiência foi aplicada no Brasil, na cidade de Campinas, constituindo-se o projeto Observatório de Qualidade de Vida da Cidade de Campinas. ${ }^{18}$, que propiciou, de acordo com AKERMAN e col (1997), o levantamento de elementos importantes na determinação de caminhos alternativos e/ou complementares para a formulação de políticas públicas. Embora os autores reconheçam que esta experiência pudesse servir como subsídio a outras cidades que fazem parte de um movimento por Cidades Saudáveis, ela não foi ampliada.

Ainda que algumas das cidades que compõem este movimento no Brasil, tenham um período de desenvolvimento superior a dois anos, não desenvolveram ainda instrumentos de monitoramento e avaliação das ações. Este é um dos pontos considerados críticos por todas as cidades. Alguns técnicos relatam a falta clareza sobre como realizar esse tipo de avaliação, como captar a percepção dos envolvidos nos projetos, como avaliar os processos de desenvolvimento.

Diz o Secretário de Saúde de Sobral:

"Eu considero isso ( a avaliação) uma coisa importante, não como indicador de resultado, mas como um indicador de processo. Para um município que tem praticamente um ano na mobilização de um município saudável não se pode exigir muita coisa em termos de resultado, o mais importante são os processos...” (Sobral 1998).

\footnotetext{
${ }^{17}$ Indicador composto é "um instrumento que permite demonstrar fenômenos em zonas geográficas específicas, classificando-os em termos de variáveis que reflitam as circunstâncias materiais ou sociais do fenômeno que se queira examinar. Ao combinar-se os diferentes indicadores, pressupõe-se a interação de vários fatores na determinação da qualidade de vida de uma determinado local" (AKERMAN 1995, p2).

${ }^{18}$ Esta experiência está relatada em AKERMAN e col (1997): A concepção de um projeto de Observatório de Qualidade de Vida: relato da experiência realizada em Campinas/SP, publicada na revista Saúde e Sociedade, da Faculdade de Saúde Pública/USP, agosto/dezembro 1997.
} 
Cidades Saudáveis no Brasil e os processos participativos: os casos de Jundiaí e Maceió

Os projetos têm se desenvolvido com a participação e compromisso de diversos atores sociais, em particular, as organizações sociais e representantes das comunidades locais?

Este ponto merece um destaque. $\mathrm{O}$ envolvimento de membros da comunidade na identificação de problemas, no desenvolvimento de soluções, na alocação de recursos e na implementação e avaliação de atividades é tido como um dos pilares dos projetos Cidades Saudáveis (PAHO 1999a). Todos os projetos brasileiros afirmam e reafirmam a importância dos processos participativos nos projetos, mas reconhecem que a prática da participação nem sempre tem sido observada como deveria, e que não vem se dando em todas as etapas do processo. Como a participação muda as relações de poder entre Estado e população, há muita resistência que sejam abertos canais para a população no interior do aparelho de Estado. Três técnicos das cidades de Diadema, Campinas e São Paulo, que tiveram seus projetos interrompidos afirmam:

“... foi um processo muito mais de técnicos do que de secretários ou de autoridades municipais" (Diadema 1998).

“... a gente tem uma análise de que foi um projeto marcadamente institucional - a gente conseguiu agregar muito pouco de organizações da sociedade civil como parceiras ..” (São Paulo 1998).

“... foi uma coisa de administração pública mesmo...particularmente, esse é o lado mais frágil para a gente, é o lado que a gente ainda não conseguiu superar, e eu acho que é muito pela incapacidade nossa, do setor público, de absorver a sociedade civil, porque na hora em que você faz isso, na hora em que você compartilha, você perde poder, você reparte poder, você reparte responsabilidade e isso é uma coisa complicada para a administração pública “(Campinas 1998).

Isto não significa que as cidades brasileiras que estão inseridas no movimento por Cidades Saudáveis não têm experimentado projetos participativos. Alguns deles desenvolvem formas de gestão participativas, como os orçamentos participativos, projeto de geração de renda e emprego, negociações entre o poder local e os 
pequenos produtores da cidade, projetos visando à implantação de agro-indústria, entre outros, que possibilitam a inserção da população no diagnóstico de sua situação, por meio de levantamento de problemas, na definição de prioridades e de soluções. As cidades têm também implementado o Programa de Saúde da Família, como uma estratégia de reorganização dos serviços de saúde, e vem criando espaços de participação que potencializam a interação governo/sociedade civil. Explica o secretário de saúde de Sobral:

“... a gestão dos serviços dos equipamentos
públicos não é necessariamente só da
prefeitura mas da comunidade também. Não
que a gente esteja transferindo a
responsabilidade do município para a
comunidade, mas construindo com a gestão.
Às vezes se confunde a gestão com
transferência, mas não é transferência, é a
idéia de trabalhar em parceria com a
comunidade na perspectiva de que a
comunidade se aproprie das políticas
públicas com cidadania, com direitos e
deveres, mas não como uma coisa de
clientelismo político” (Sobral 1998).

Uma das questões mais importantes para viabilizar a participação efetiva, e um dos desafios a ser empreendido pelos projetos Cidades Saudáveis, é a capacidade de informar e manter informado, de garantir o acesso dos cidadãos à informação, indispensável ao processo administrativo, já que torna transparente a interação pretendida entre Estado e sociedade civil. O que freqüentemente se observa, porém, é a dificuldade dos governos de disseminar a informação. Os projetos interrompidos, bem como aqueles em desenvolvimento, mostram que manter um fluxo de informações permanente é um dos grandes desafios a ser enfrentado. Estratégias de troca de informações têm sido implementadas, como o uso de rádio local, jornais impressos, material impresso de divulgação. Isto, entretanto não tem alcançado os resultados esperados, que em última instância significa alcançar toda a sociedade local, sensibilizando e motivando os indivíduos a desenvolver práticas participativas que possam viabilizar propostas de atuação conjunta.

Se a população tem sido protagonista nos projetos Cidades Saudáveis, se esses projetos são expressão de uma decisão coletiva entre as instituições e os 
Cidades Saudáveis no Brasil e os processos participativos: os casos de Jundiaí e Maceió

cidadãos, se as organizações sociais e representantes dos fóruns de debate dos projetos representam os anseios da população, são questões que tentamos responder s dois estudos de caso que realizamos e apresentaremos no Capítulo 5.

\section{AS CIDADES QUE INTERROMPERAM SUAS EXPERIÊNCIAS}

\section{As cidades de São Paulo, Santos e Campinas no Estado de São Paulo; Palmeira, no Paraná e Iraquara, na Bahia}

Dentre as 20 cidades que iniciaram trabalhos na perspectiva do movimento por Cidades/Municípios Saudáveis no Brasil, cinco interromperam seus processos. O histórico da inserção de cidades ao movimento por Cidades/Municípios Saudáveis que se deu no país faz ver que alguns dos centros econômicos mais importantes, como a cidade de São Paulo, Campinas, Santos, no Estado de São Paulo, investiram muitos esforços, direcionando suas políticas de governo para a busca da qualidade de vida. Algumas dessas experiências alcançaram projeção internacional, como Campinas e Santos, e serviram de modelo para o desenvolvimento de outras.

Observa-se, em todas elas, que o papel do prefeito foi de apoio e de envolvimento bastante claros. No caso de Campinas, o prefeito chegou a envolver-se pessoalmente, realizando contatos com as agências internacionais de fomento à proposta. Portanto, a implantação dos projetos Cidades Saudáveis nessas cidades foi viabilizada pela existência de um contexto político favorável, caracterizado pela convergência de interesses e vontades políticas manifestadas em várias áreas da municipalidade.

A interrupção dos projetos ocorreu após as mudanças administrativas. Como vimos, são inúmeros os fatores que dificultam a continuidade das experiências iniciadas em uma gestão anterior, como instabilidade política, prevalência da política setorial, falta de apoio técnico aos projetos, dificuldade de ampliar parcerias fora do setor governamental, falta de mecanismos de informação e comunicação que garantam democratização das informações para a sociedade em geral, dificuldade em criar mecanismos de monitoramento e avaliação dos projetos. Vários desses fatores são mencionados por técnicos que acompanharam os processos de implantação dos projetos nas cidades. 
Muito embora essas cidades tenham iniciado a discussão da inserção ao movimento por diferentes vias, não se observam diferenças significativas de enfoque. São Paulo e Santos iniciaram seus projetos com técnicos canadenses da cidade de Toronto, enquanto Campinas, Palmeira e a cidade de Iraquara da Bahia, aproximaram-se do ideário por meio da Organização Pan-Americana de Saúde.

\section{Estado de São Paulo}

\section{São Paulo}

São Paulo, a maior cidade do país, com aproximadamente 10 milhões de habitantes, durante o governo progressista, de 1989 a 1992, viveu importantes transformações na gestão pública. Nesse período, a administração municipal da cidade de São Paulo, por meio da Secretaria de Planejamento, buscava ampliar as relações internacionais e abrir novos caminhos. O convênio de cooperação técnica com a cidade de Toronto, que existia desde 1986, permitiu visitas bilaterias de técnicos, visando ao aprofundamento das relações entre os dois países. Este convênio permitiu o acesso do município a informações sobre o movimento Cidades Saudáveis, conhecer melhor a sua amplitude e manter algum tipo de relação com a Organização das Nações Unidas e como decorrência, com a Organização Mundial de Saúde.

Técnicos de Toronto visitaram São Paulo e promoveram discussões conceituais sobre o tema, e em 1991, foi realizado um seminário que definiu como linha de intervenção do governo municipal o modelo de Cidades Saudáveis, tendo sido constituídos a partir desse evento, grupos de trabalho.

A área de saúde, desde o ano de 1989, já desencadeava um processo de reforma, de acordo com os princípios do Sistema Único de Saúde, pautado na descentralização e na formação das Administrações Regionais de Saúde e Distritos de Saúde, como organismos descentralizados de articulação da política de saúde no âmbito da prevenção, promoção, além da recuperação da saúde. Pareceu importante, portanto, incluir a questão da qualidade de vida na formação dos Distritos de Saúde dentro desse processo de descentralização da política da cidade, com a participação da sociedade civil, com um enfoque mais amplo de saúde - a saúde não depende apenas de equipamentos de hospitais, de ambulância de profissionais, mas também, de políticas sociais e econômicas voltadas à redução de agravos. Enfim, a área de saúde procurou abordar a questão da qualidade de vida, da cidadania, o conceito de Cidades Saudáveis, entendendo que estes não eram uma responsabilidade apenas do poder público, mas também da sociedade civil.

No segundo semestre do ano de 1991, a administração definiu a região central como prioritária, dando início ao projeto "Centro Saudável", que partia do pressuposto de que as questões de saúde precisam estar relacionadas às questões de qualidade de vida. Técnicos que atuavam na Secretaria de Saúde tinham um entendimento da proposta:

“... não dava pra você trabalhar as questões de saúde na região central desvinculada da questão da qualidade de vida. .. e no caso da região central, essa questão até ficava mais evidente, na medida em que você tinha vários fatores relacionados à poluição sonora, poluição do ar, os cortiços, a precariedade das condições de habitação - uma série de fatores que faziam com que a população viesse a ter problemas de saúde" (São Paulo 1998).

Outro fator decisivo para implementação do Centro Saudável foi o processo vivenciado pela Administração Regional da Sé, que assumiu a coordenação de todos os serviços e obras e manutenção da região central, experimentando uma proposta de construção de governo local, ou seja, de uma subprefeitura alocada na região centro. Mesmo sem se ter as sub-prefeituras regulamentadas pelo Legislativo, buscou-se um trabalho intersetorial envolvendo as diversas secretarias de governo. Portanto, nesse trabalho estavam envolvidas a Administração Regional da Sé, Secretaria da Saúde, da Educação, da Cultura, da Habitação, do Bem-Estar Social, que esboçaram um plano de trabalho, enquanto um projeto de intervenção da experiência de governo local. Além disso, esta era a região que tinha um pequeno número de equipamentos de saúde, o que colocava a necessidade de buscar novas 
formas de fazer saúde. Um dos trabalhos foi denominado Praça Saudável, realizado todas as sextasfeiras, na Praça da Sé, onde eram desenvolvidas atividades de educação em saúde, sobre AIDS, sexualidade, acompanhamento de imunização, orientação sobre o funcionamento dos serviços na região.

Este trabalho começou em junho de 1991, crescendo no primeiro semestre de 1992 e enfrentando o processo eleitoral no segundo semestre de 1992. Com a perspectiva de não continuidade administrativa, ficou difícil acenar com uma perspectiva de continuidade do projeto. Alguns se afastaram por entender que este era um projeto para reeleger o governo, outros se afastaram ao verificar que aquele conjunto de forças políticas não tinha condições de ganhar a eleição.

Com a mudança administrativa ocorrida no ano de 1992, o setor saúde, que impulsionava o desenvolvimento do projeto, refluiu. A nova administração passou a ter outra lógica de trabalho e os projetos intersetoriais foram paralisados. Tem-se conhecimento de que o projeto por Cidades Saudáveis permanece vinculado à Secretaria do Planejamento, que continuou com uma rubrica e mantém o intercâmbio São Paulo/Toronto, mas não há qualquer ação sendo desenvolvida.

A Agenda 21, que teve início também nessa administração e que tem muitos pontos de contato com o projeto Cidades Saudáveis, permaneceu como um projeto em discussão que avançou muito pouco nesses últimos anos. Em uma reunião, ocorrida em junho de 1998, da Oficina Permanente de Estudos e Programas sobre Cidades Saudáveis na Câmara Municipal de São Paulo, o então Secretário do Planejamento da prefeitura compareceu,e em discurso público, comprometeu-se a realizar dois projetos piloto, reativando o do centro da cidade e iniciando outro na Zona Leste de São Paulo. Até o momento nada de concreto ocorreu.

.Atualmente a prefeitura da cidade de São Paulo vem retomando acordo de cooperação técnica com a cidade de Toronto visando a retomada da parceria entre o Brasil e o Canadá. Iniciativas na perspectiva do projeto Cidades Saudáveis vem sendo discutidas para a definição de "Distritos Saudáveis", na região sul da cidade.

\section{CAMPINAS}

A cidade de Campinas possui cerca de 1 milhão de habitantes e está localizada a $100 \mathrm{Km}$ da capital do Estado. O histórico de inserção da cidade de Campinas ao movimento por Cidades Saudáveis inicia-se no segundo semestre de 1994, através de um acordo de cooperação técnica firmado entre a Prefeitura de Campinas e a Organização Pan-Americana de Saúde. A cidade já possuía uma série de iniciativas que vinham se desenvolvendo, mas dois movimentos contribuíram basicamente para a implantação deste Projeto:

O primeiro movimento começou em 1993, com discussão da distritalização da saúde, denominado de Gestão Social Inter-Setorial e Descentralizada, quando vislumbrou-se a possibilidade de desenvolver um projeto em uma perspectiva intersetorial e integrada, dado que nesse período estava ocorrendo um processo de reforma administrativa municipal. Nesta reforma foram criadas 4 Secretarias Municipais de Ação Regional (SARs), dando início a um processo de descentralização, cujo objetivo era fortalecer um modelo de gestão baseado em três fatores: a integração das ações, a participação popular e a flexibilização organizacional. Esse processo coincidia com os princípios da proposta de Cidades Saudáveis, no que diz respeito à participação da sociedade em todos os níveis, parcerias com as Organizações Não-Governamentais e a perspectiva de melhoria da qualidade de vida.

O segundo movimento foi decorrente de uma visita do prefeito de Campinas à OPAS de Washington, em julho de 1994, de onde voltou sensibilizado para a implantação do Projeto Cidades Saudáveis.

O projeto Cidades Saudáveis acabou dando outra dimensão para os projetos que já vinham sendo desenvolvidos no cotidiano da cidade. Na assinatura do acordo de cooperação técnica, assessores da OPAS visitaram a cidade, o que, do ponto de vista institucional, foi considerado uma força no sentido de mobilizar para a idéia. Sob a marca Cidades Saudáveis ficaram articulados todos os projetos de governo que já trabalhavam nessa perspectiva: Projeto de Combate à Fome, Projeto de Renda Mínima, Projeto de Combate à Desnutrição Infantil, dentre outros. 
Em março de 1996, o projeto já era considerado um modelo e por isso a cidade sediou o $I$ Congresso Latino Americano para Cidades e Comunidades Saudáveis, do qual resultou a CARTA DE CAMPINAS. Este evento reuniu, durante três dias, gestores e políticos municipais, técnicos nacionais e internacionais, e reconheceu a importância da visão de saúde relacionada a seus determinantes econômicos, sociais, biológicos e políticos. Apontou os governos locais como instância estratégica na condução e gerenciamento das ações de construção da cidadania e da democracia participativa e ainda, reforçou a necessidade da busca da integralidade das ações e a importância da soma de esforços entre todos os setores em prol de municípios, cidades e comunidades saudáveis. Considerou, enfim, como resultante deste movimento, o aprendizado de uma nova forma de governar.

O complexo São Marcos, formado por 5 bairros da periferia da cidade, numa das regiões mais carentes, com uma população de 22 mil habitantes, e o Jardim Florence, tiveram um trabalho na linha de Cidades Saudáveis com acompanhamento da OPAS, com metodologias e planos de ação próprios, calcados nos princípios da intersetorialidade e de participação. Através da metodologia de estimativa rápida, foi feito um reconhecimento do território, com o objetivo de conhecer as condições de vida, identificar problemas e selecionar prioridades. Feito o diagnóstico foram realizadas algumas atividades, como a Feira de Projetos, com a participação de instituições públicas, organizações nãogovernamentais, conselhos comunitários; foram eventos que envolveram centenas de pessoas, e que culminaram na elaboração de um plano intersetorial.

De acordo com informações, o projeto foi sendo desativado com a morte do Prefeito em 1996, tendo sido interrompido em 1997, com a mudança administrativa, como uma política de governo. No entanto, uma série de iniciativas que foram feitas naquela ocasião, continuam até hoje por força das organizações sociais, especialmente no Complexo São Marcos. O prefeito atual, às vezes, chega a verbalizar que vai reiniciar o projeto, mas não chegou ainda a concretizar suas propostas.

\section{SANTOS}

A cidade de Santos está localizada na Baixada Santista, a $80 \mathrm{Km}$ da cidade de São Paulo, e possui cerca de 400 mil habitantes. Desde 1989, Santos trabalhava com uma concepção próxima à de Cidades Saudáveis. Com esta denominação, foi realizado um encontro de Cidades Saudáveis, de iniciativa da Secretaria de Saúde, em meados de 1994, com a presença de um técnico canadense na cidade, que acabou envolvendo outras áreas da administração pública.

A Secretaria do Meio Ambiente já vinha trabalhando nessa linha com a Agenda 21, que, para os técnicos, tinha um significado bastante semelhante. Tentou-se trabalhar a Agenda 21 e o projeto Cidades Saudáveis em diversas ações intersetoriais da prefeitura.

Foi adotada a marca Santos Saudável, que era entendida como uma concepção ideal de cidade. Esta discussão esteve centrada, num primeiro momento, muito mais no setor saúde. O próprio Conselho Municipal de Saúde, depois da IV Conferência Municipal de Saúde, de 1996, mudou seu nome para "Conselho Municipal de Saúde de Santos- Cidade Saudável" , e resolveu-se que seria composto por diversas áreas de governo que não só o setor saúde, mas também o da educação, o de ação comunitária, o do meio ambiente, o da habitação.

Com a mudança administrativa ocorrida em 1996 embora alguns dos programas da área de saúde tenham tido continuidade, não houve continuidade dessa política de governo.

\section{ESTADO do PARANá}

\section{PALMeIRA}

Palmeira possui cerca de 30 mil habitantes e está localizada na região sul do Estado do Paraná, a $75 \mathrm{Km}$ de Curitiba. Foi o primeiro município no Estado a assumir a ideologia do movimento por Cidades Saudáveis, o que ocorreu em 1995. Inicialmente, a administração municipal lançou uma etapa denominada Reparadora. Nesta fase, foram injetados mais recursos na assistência básica à 
população nas áreas de educação e saúde. Com o desenvolvimento da idéia de Município Saudável, as discussões procuraram englobar as ações intersetoriais e a participação. Vários conselhos foram formados nas áreas de saúde, assistência social, criança e adolescente. Dentre as prioridades apontadas naquele momento, foram destacadas: controle de desnutrição, despoluição do Rio Monjolo, moradia, desemprego, destino do lixo.

Foi também proposta a formação de um Conselho Comunitário - Comitê para a Saúde, que não chegou a ser implantado, que tinha por objetivo apontar as prioridades do município, do ponto de vista da população.

Com a mudança administrativa ocorrida no ano de 1996, o projeto de Cidade Saudável em Palmeira, não teve continuidade e, de acordo com depoimentos, não houve mais contato com técnicos da Secretaria de Estado da Saúde do Paraná, que discutiam as diretrizes do projeto na cidade.

\section{ESTADO DA BAHIA}

\section{IRAQUARA}

O município de Iraquara possui 18 mil habitantes e está localizado a $480 \mathrm{Km}$ de Salvador, capital do Estado da Bahia. A discussão do projeto Municípios Saudáveis iniciou no ano de 1994 através de contato com técnicos da Organização Pan-Americana de Saúde. Houve inicialmente um processo de sensibilização com todos os segmentos da sociedade e a formação de alguns conselhos, como o de Saúde e Educação. Este projeto encontrou condições de ser desenvolvido, especialmente porque no município já existiam outros programas com perspectivas comuns, como o Programa de Desenvolvimento Sustentável. Com a troca de administração no ano de 1996 o projeto foi interrompido, embora haja intenção em retornar as discussões, de acordo com o responsável pela área de saúde.

\section{AS CIDADES QUE SE APROXIMARAM DO MOVIMENTO}

\section{As cidades de Diadema, no Estado de São Paulo e Céu Azul, no Paraná}

Essas cidades tiveram uma aproximação com o movimento por Cidades/Municípios Saudáveis, mas não chegaram a implementar ou discutir ações nesta perspectiva. Foram sensibilizadas, mas alegam dificuldades políticas para dar prosseguimento ao projeto.

O caso de Diadema é bastante ilustrativo. Foi realizado um Encontro que tratou do tema Diadema Cidade Saudável, mas, de acordo com técnicos, não havia, naquele momento, condições mínimas para o desenvolvimento do projeto, especialmente porque a cidade não tinha trajetória de articulação intersetorial ou de políticas articuladas entre as várias secretarias. Assim, a soma de variáveis políticas e administrativas inviabilizou a conformação do projeto na cidade. O depoimento de um ex-técnico ilustra o conflito que se estabeleceu na política local, e que nada contribuiu para o estabelecimento de políticas públicas: 
“...a administração, de modo geral, tinha dificuldade com outros níveis de governo, que internamente tinha pouco acúmulo no sentido da necessidade de uma ação mais descentralizada e mais articulada entre departamentos e empresas municipais. E do ponto de vista político, na verdade, a cidade, a administração e o partido que governava a cidade viviam um grande momento de conflito interno, onde a secretaria da saúde, representava um determinado grupo e o resto do secretariado e o prefeito representavam um outro grupo político. Essas facções não chegaram em nenhum momento a um consenso ou uma síntese, essa crise evoluiu para a derrota eleitoral de 1996..." (Diadema 1998)

\section{Estado de São Paulo}

\section{DIADEMA}

Diadema possui 328 mil habitantes e localiza-se na região metropolitana de São Paulo. A primeira aproximação de Diadema com a proposta de Cidades Saudáveis se deu por meio de técnicos da administração da cidade de São Paulo, que nos anos de 1991-1992 mantiveram um convênio de cooperação técnica com a cidade de Toronto. Foram estabelecidos os primeiros contatos com o técnico canadense Jack Lee, em 1994, que resultou em um convite para que ele participasse de um Encontro Municipal de Saúde que teve como tema: Diadema, Cidade Saudável rumo ao ano 2000. Este Encontro contou com a participação de cerca de 500 pessoas.

A motivação para conhecer esta proposta se deu pelo fato de que havia uma constatação de uma certa ineficiência do trabalho desenvolvido em saúde, no sentido de melhorar a qualidade de vida. O modelo de saúde vigente estendeu a cobertura, atendendo muitas pessoas, produzindo muitas consultas, mas continuava centralizado na assistência individual, médica. Além disso, o símbolo "Diadema - Cidade Saudável" indicava para uma perspectiva de futuro que precisava começar a ser construída.

O Encontro foi a única iniciativa e, de acordo com técnicos, não havia naquele momento condições políticas mínimas para o desenvolvimento do projeto.

A ação considerada mais próxima do ideário de Cidades Saudáveis foi a realização de oficinas de territorialização, que teve assessoria da Faculdade de Saúde Pública da USP e foi realizada conjuntamente com representantes da população, representantes da Secretaria de Saúde, funcionários de unidades básicas e representantes de outros departamentos municipais, principalmente da área de educação, de saneamento, habitação. Ocorreram alguns desdobramentos desse processo, com intervenções nos bairros.

\section{Estado do Paraná}

\section{CÉu AzUL}

Céu Azul, do Estado do Paraná, com uma população de 10.500 habitantes, foi um dos municípios que se aproximou da filosofia do movimento. As Atas do Conselho Municipal de Saúde do município, de 1995, registram que na III Conferência Municipal de Saúde desse mesmo ano, o prefeito da cidade fez menção ao movimento por Município Saudável e que houve um esclarecimento 
de uma técnica sobre os pressupostos do movimento, enfatizando a importância do envolvimento da comunidade na melhoria da qualidade de vida. A participação do prefeito no I Congresso Latino Americano para Cidades e Comunidades Saudáveis ocorrido em Campinas, Estado de São Paulo, em 1996, fez com que, em comemoração ao Dia Mundial da Saúde, o tema Municípios Saudáveis fosse por ele ressaltado. As políticas intersetoriais, a participação da população e a determinação social do processo saúde-doença foram destacadas. Neste mesmo ano, em uma das Atas do Conselho Municipal de Saúde foi relatada a intenção de contratação de um técnico/assessor para auxiliar no desenvolvimento do projeto no município.

No entanto, com a mudança administrativa ocorrida no ano de 1996, essas discussões não tiveram continuidade.

Também em âmbito estadual houve um recuo, o que foi explicado por um dos entrevistados como um momento de reflexão em que os profissionais de saúde questionaram qual era o real papel do setor da saúde nesse processo e a falta de envolvimento de outros setores, inviabilizando a concretização da proposta: "não dá pra dizer que é só a saúde que vai puxar esse processo...ela necessita de outras políticas junto, de geração de emprego e renda, educação, abastecimento..." (Céu Azul, 1998)

\section{AS CIDADES COM EXPERIÊNCIAS EM ANDAMENTO}

As cidades de Jundiaí, Vargem Grande Paulista, no Estado de São Paulo; Arapiraca, Flexeiras, Anadia, Maceió, em Alagoas; Dionísio, São José do Goiabal, em Minas Gerais; Fortaleza, Sobral e Crateús, no Ceará, Curitiba e Chopinzinho, no Paraná.

Muitas das cidades que se aproximam do movimento por Cidades Saudáveis, no país, têm um desenvolvimento ainda inicial e incipiente. Os prefeitos ou secretários da saúde das cidades mostram interesse pela proposta, são incentivados por diferentes instituições, como vimos anteriormente, mas seus projetos e estratégias não são homogêneos e ensejam vários modelos de intervenção, muitos ainda voltados à reorganização dos serviços de saúde, outros dirigidos às áreas de agricultura, educação ou meio ambiente. Poucos são os municípios que investem em redirecionar suas ações, com vistas a realizar um planejamento intersetorial, mas todos referem que têm como princípio norteador a participação de amplos setores da sociedade, no sentido de reforço às práticas democráticas.

Pode-se observar que o desenvolvimento dessas iniciativas deu-se em contextos políticos favoráveis em que o compromisso político de prefeitos à proposta determinou o estabelecimento de ações mais articuladas e participativas. Mesmo assim, pode-se perceber que o entendimento do movimento por Cidades/Municípios Saudáveis é ainda bastante heterogêneo. Alguns prefeitos de pequenas cidades do Nordeste mostraram nas entrevistas, confiança no trabalho proposto pelo secretário 
Cidades Saudáveis no Brasil e os processos participativos: os casos de Jundiaí e Maceió

da saúde, o impulsionador do ideário, e assumem um projeto de governo que ainda não conseguem entender como será operacionalizado. A sensibilização desses prefeitos parece ser o primeiro grande desafio a ser empreendido na definição de projetos por Cidades/Municípios Saudáveis.

Cidades como Curitiba e Fortaleza têm uma inserção diferenciada no movimento. São cidades que têm experimentado formas alternativas de gestão com ênfase na descentralização e na intersetorialidade. Curitiba, como discorre FERRAZ (1999) já é um exemplo de Cidade Saudável, mesmo sem o desenvolvimento formal de um projeto. A cidade tem uma longa tradição de planejamento urbano e muitas agendas encontram nela um cenário ideal para seu desenvolvimento. Desenvolve 21 projetos matriciais tendo como referência a intersetorialidade entre os diversos setores de governo e a constituição de parcerias com instituições públicas e privadas. De acordo com informações colhidas entre os técnicos da cidade, a cidade se aproximou do ideário Cidade Saudável em 1994, e ainda hoje desenvolve projetos nesta perspectiva, como o Cidadão Saudável, e um projeto de definição de indicadores de qualidade de vida, que tem por base os estudos desenvolvidos pelos projetos Cidades Saudáveis da Europa.

Fortaleza experimenta desde o ano de 1997 uma nova lógica de organização do aparato governamental que tem como princípio a intersetorialidade e a participação. Como salienta JUNQUEIRA (1997), Fortaleza buscou modelar uma nova organização, introduzindo um novo modo de gerenciar para tornar a cidade saudável.

Pode-se notar que o movimento por Cidades/Municípios Saudáveis no Brasil vem se ampliando. Nos anos de 1998 e 1999, ocorreram várias iniciativas com o objetivo de discutir a sustentação do movimento e definir as bases para a consolidação de uma rede nacional, com a participação de municípios de todas as regiões do país. Por ocasião do XV Congresso Nacional de Secretários Municipais de Saúde, ocorrido no Rio de Janeiro, em agosto de 1999, foi iniciada a organização da Rede Brasileira de Municípios Saudáveis, tendo sido designado o coordenador da Comissão Provisória, o prefeito de Crateús, que deverá estabelecer uma estratégia de trabalho, convocando os prefeitos interessados em assumir projetos nessa 
perspectiva. A designação de um prefeito para a coordenação desse processo aponta um aspecto importante, o de considerar essas iniciativas como propostas de governo e não somente ligadas ao setor da saúde.

\section{Estado de São PaUlo}

\section{JUNDIAÍ}

A cidade de Jundiaí possui 280 mil habitantes e está localizada a $65 \mathrm{Km}$ da capital do Estado. O projeto Cidade Saudável, em Jundiaí, iniciou-se em meados de 1994, quando técnicos da Coordenadoria Municipal de Planejamento e da Secretaria Municipal da Saúde de Jundiaí iniciaram contatos com técnicos canadenses do Departamento de Saúde da cidade de Toronto. O objetivo inicial foi conhecer a experiência canadense e avaliar a possibilidade de implantar um projeto na cidade. $\mathrm{O}$ principal desdobramento foi a realização de um seminário na cidade que envolveu vários segmentos da sociedade, funcionários públicos, vários setores do governo municipal, a Coordenadoria de Planejamento, as Secretarias da Saúde, da Educação, da Administração. Nesse seminário, foram debatidas as possibilidades de se realizar um trabalho no município, a partir das concepções e a filosofia de um projeto de Cidades Saudáveis.

O projeto ainda está em andamento e tem sofrido mudanças, sendo que o grupo inicial que discutiu a proposta em 1994, tem acompanhando o desenvolvimento do projeto até os dias de hoje. São citados o Instituto Serra do Japi, Conselhos Comunitários, associações de bairro da Vila Áries e da Vila Anhangabaú, a Fundação Municipal de Ação Social (FUMAS), o Conselho de Pessoas Portadoras de Deficiências, a CETESB, a Associação dos Arquitetos do Brasil, a Associação dos Contabilistas e Economistas.

Os primeiros problemas apontados, definiram a necessidade de elaboradar políticas direcionadas ao reforço de ações para diminuição de resíduos sólidos (lixo) nas residências e, portanto, voltadas a ações sobre o meio ambiente relacionadas à prevenção de doenças. Num primeiro momento, foram reconhecidos projetos que tinham identidade com a questão ambiental a qual se relacionava a proposta de Cidades Saudáveis, como o Cata-treco, que visa recolher entulhos das residências. Outra prioridade foi o controle da violência por meio do Policiamento de Bairro, implantado na cidade pela polícia militar, preocupada com o aumento dos índices locais de violência. A iniciativa de busca de soluções participativas planejadas deu início ao projeto Conheça seu bairro, proposta de territorialização e identificação de problemas e equipamentos públicos existentes nos bairros.

Muitas das ações não foram ainda avaliadas. A equipe coordenadora do projeto acredita, entretanto, que algumas ações tiveram resultado positivo, pelo menos em nível de sensibilização. Por exemplo, os concursos envolvendo a rede pública de educação trouxeram para as escolas a discussão sobre o meio ambiente, a influência das políticas públicas na qualidade de vida, relação homem e meio ambiente. O impacto maior foi na área de educação, mais especificamente, no campo da educação ambiental.

Outro aspecto positivo diz respeito à participação de setores da população. A cidade já possuía lideranças com um potencial para a participação, que a equipe acredita que se ampliou com as discussões do projeto. Há indícios, também, de que o projeto esteja promovendo a colaboração e solidariedade entre os membros da comunidade. Foi o maior salto que se pôde alcançar, já que os movimentos que existiam na cidade eram desarticulados entre si e encontraram na agenda da Cidade Saudável um referencial comum, através do Conselho da Cidade Saudável e do Comitê Executivo do projeto. O Conselho da Violência foi um dos produtos desse encontro de interesses.

O Projeto vem motivando o desenvolvimento de políticas públicas integradas, mas isso não tem se concretizado no trabalho entre as secretarias da administração municipal.

Não existe uma rede de comunicação que garanta a troca de informações com vistas ao desenvolvimento do Projeto. Os jornais locais e rádios contribuíram para divulgar informações de eventos e os preceitos do ideário, mas foram os concursos de redação realizados nas escolas, que envolveram 60.000alunos, que possibilitaram maior sensibilização e divulgação da idéia. No primeiro 
deles, os alunos redigiram o tema: "O que você acha que é uma Cidade Saudável” e, no segundo, os alunos desenvolveram o tema "o que você pode fazer para construir uma Cidade Saudável". Ambos tiveram como vencedores, alunos de escolas das áreas periféricas da cidade. Foi feito um boletim para divulgar o resultado do concurso que foi considerado de alto impacto na cidade

Existe uma avaliação, no entanto, de que nem sempre estas formas de divulgação garantiram a troca de informações. Na gestão do projeto não se conseguiu, por exemplo, incluir lideranças dos bairros populares da cidade.

Este projeto manteve-se, apesar da mudança de governo, mas sua sustentação tem sido muito frágil. O Comitê Cidade Saudável reúne-se quinzenalmente e busca redefinir os objetivos e ações do Projeto na cidade. Este projeto será analisado em profundidade como um estudo de caso específico no Capítulo 5.

\section{VARgem Grande Paulista}

Vargem Grande Paulista possui 26 mil habitantes e localiza-se na Grande São Paulo, distante $40 \mathrm{Km}$ da capital. A proposta de integrar o município no movimento por Cidades Saudáveis ocorreu no ano de 1996, quando a idéia foi apresentada pela Faculdade de Saúde Pública da USP, que desde o ano de 1988 realiza trabalhos conjuntos na cidade, oferecendo assessoria e serviços técnicos especializados em diversas áreas. Em visita ao município, técnicos da Organização Pan-Americana de Saúde, reunidos com o prefeito, vereadores e lideranças locais, chegaram à conclusão de que diversas iniciativas que estavam se dando no município já se inseriam nessa filosofia, especialmente as ações voltadas ao meio ambiente e com participação popular. O município foi considerado em condições de integrar o movimento, tendo sido viabilizada uma visita de uma delegação ao Paraná para conhecer as experiências de Curitiba e Palmeira, que estavam se concentrando na resolução de problemas ambientais semelhantes aos da cidade.

Houve o compromisso com o Projeto, da administração eleita em 1997, que apoiou a realização de um Fórum Regional sobre Municípios Saudáveis, que contou com a participação de alguns prefeitos e de todos os secretários de saúde das cidades vizinhas.

A administração centrou sua atuação na problemática da criança e do adolescente e reuniu os setores de governo e os Conselhos para elaborar um Plano de Ação Conjunta para formação integral da criança e do adolescente. Um fórum municipal de direitos da criança e do adolescente, intersetorial e com participação da sociedade civil, vem monitorando o desenvolvimento do Plano, enquanto as secretarias vêm desenvolvendo suas ações específicas. Também vem sendo desenvolvido um projeto piloto de Educação Ambiental/Educação em Saúde, objetivando uma Cidade Saudável em cinco escolas localizadas em pontos estratégicos da cidade, com assessoria da Faculdade de Saúde Pública. Professores estão sendo capacitados para atuar junto aos alunos, pais e comunidade no entorno das escolas, visando à melhoria das condições de vida locais. Acredita-se, que com isso, o acesso das crianças e adolescentes à educação, cultura e lazer estão sendo favorecidos, bem como programas de geração de emprego e renda, alfabetização de adultos, entre outros.

Apesar da diversidade de programas em andamento, há necessidade, ainda, de uma maior coordenação e monitoramento do Plano, ação difícil de ser adotada pelos governos municipais, acostumados a solucionar problemas pontuais.

\section{ESTAdo de Alagoas}

\section{MACEIó}

Maceió, capital do Estado de Alagoas, possui cerca de 800 mil habitantes, optou por realizar pequenas experiências Comunidades Saudáveis, como iniciativas piloto, ao invés de implantar um projeto mais amplo abrangendo toda a cidade.

A aproximação de Maceió com o projeto Cidades Saudáveis teve início após a participação da secretária de saúde da cidade no I Encontro dos Secretários de Saúde das Américas, que se deu em Fortaleza, em 1995. O contato com a experiência do Canadá motivou a Secretaria Municipal de Saúde 
a construir um projeto que tivesse o intuito de buscar a melhoria da qualidade de vida da população. Outras ações com este objetivo já vinham sendo realizadas, no sentido de melhorar o perfil epidemiológico, mas não estavam surtindo o impacto desejado. Assim, iniciou-se em 1996, o trabalho nas comunidades de Grota do Arroz, Grota do São Rafael e Loteamento Santo Onofre, localizadas no bairro de Cruz das Almas e, em 1997, na comunidade de Pontal da Barra. As comunidades de Cruz das Almas foram selecionadas para iniciar o projeto por se constituírem em comunidades muito carentes, e a do Pontal da Barra foi escolhida por ser um importante centro turístico da cidade e ter uma comunidade organizada, que luta por melhoria de sua condição de vida.

O processo de distritalização do setor da saúde, a implantação do Programa de Saúde da Família e do Orçamento Cidadão são consideradas políticas que contribuem para a discussão dos projetos Comunidades Saudáveis.

As parcerias referidas são a Universidade Federal de Alagoas e as associações locais.

Os projetos Comunidades Saudáveis de Maceió serão analisados em profundidade , como um estudo de caso específico no Capítulo 5.

\section{ANADIA}

O município de Anadia localiza-se a $88 \mathrm{Km}$ de Maceió, na região agreste úmido, e possui 16.500 habitantes. O interesse do município com o tema Cidades Saudáveis começou com o conhecimento do manual publicado pela Secretaria de Saúde do Paraná, "Municípios Saudáveis: iniciativas de implantação", e com a participação do secretário da saúde no Fórum Regional de Municípios Saudáveis, realizado em 1997, no município de Vargem Grande Paulista, Estado de São Paulo. Com a mudança de administração, começou-se a vislumbrar, no ano de 1997, a possibilidade de realizar um governo diferente. O primeiro passo foi realizar um diagnóstico, que foi desencadeado pelo setor saúde, na perspectiva de observar a totalidade dos problemas. Em seguida, o município foi geograficamente dividido em 5 distritos, 3 na zona rural, 1 na periferia da cidade e 1 na zona urbana, com o objetivo de organizar a assistência à saúde e realizar um planejamento de ações preventivas e curativas. Com o propósito de identificar os problemas e preparar um plano de ação, foram coletadas informações nos povoados, por intermédio de agentes comunitários, em relação a qualidade da água, manejo do lixo, assistência médica, doenças mais comuns, depósito de dejetos, meios de produção e condições de vida em geral.

Para encaminhar propostas de ação foi pensada a possibilidade de adotar as estratégias de Municípios Saudáveis, sendo que o primeiro passo nessa direção foi o contato com a Universidade Federal de Alagoas, através do NUSP- Núcleo de Saúde Pública. O contato com a Organização PanAmericana de Saúde em Brasília, deu-se logo após, com a apresentação de um projeto que colocava a intenção do município em adotar estratégias de Municípios Saudáveis. A Faculdade de Saúde Pública da USP, indicada pela OPAS para assessoria ao município, tendo participado da Conferência Municipal de Saúde de Anadia, "Município Saudável e Cidadania".

Neste momento, constituiu-se o Conselho Diretor do Município Saudável, com a participação dos diferentes setores da administração municipal. Houve o Fórum de Municípios Saudáveis de Arapiraca, onde estiveram presentes todos os secretários, que delinearam a preparação de um Plano Estratégico de Desenvolvimento do município. Seis meses depois, com a assessoria da Faculdade de Saúde Pública, elaborou-se, em Anadia, o Plano Municipal de Desenvolvimento Social, com a participação dos conselheiros distritais, sendo estabelecidas metas e diretrizes de ação. Neste Plano, todas as ações foram pensadas em conjunto, o que pressupôs o trabalho integrado de todos os setores. Onze problemas foram apresentados e, ações para resolvê-lo tem sido discutidas em conjunto, tendo em vista a elaboração de um plano conjunto. O município conta hoje com um Comitê Diretor de Desenvolvimento Social, que discute e elabora todas as políticas. Ele é formado pela prefeita, um representante da câmara de vereadores e por um representante de cada conselho setorial, que são os conselhos de saúde, educação, alimentação escolar, desenvolvimento rural, da criança e do adolescente e da assistência social. 
As prioridades governamentais centralizam-se na reorganização das ações de saúde, tendo sido implantado o Programa de Saúde da Família, em que atuam agentes comunitários. Outro projeto prioritário é o de manutenção da criança na escola. A diminuição da evasão e repetência são prioridades do governo. O incentivo à produção agrícola e o apoio ao pequeno produtor é outra vertente prioritária do projeto local.

Após um ano de implementação do projeto, os técnicos acreditam que houve modificação no modelo de atenção à saúde, que deixou de estar centrado exclusivamente na atenção curativa, individual. Hoje, adota-se o modelo do Programa de Saúde da Família, que começa a ser estendido a todo o município. Houve modificação e avanços na área de educação, especialmente relacionado ao modelo pedagógico adotado, hoje mais progressista. Os indicadores de educação e saúde estão passando por mudanças significativas: houve redução da evasão escolar e diminuição do índice de mortalidade geral.

Os parceiros citados são as Universidades- NUSP Núcleo de Saúde Pública da Universidade Federal de Alagoas, a Faculdade de Saúde Pública da USP e a comunidade local.

Os conselhos distritais têm se reunido mensalmente e têm trocado informações, sendo os principais canais de divulgação das ações. A rádio comunitária é considerada também um importante veículo difusor e mobilizador da população em torno do projeto.

\section{ARAPIRACA}

O município de Arapiraca situa-se a 128 km de Maceió, capital do Estado de Alagoas e possui cerca de 170 mil habitantes. O primeiro contato com a proposta de Municípios Saudáveis foi por ocasião da participação da secretária da saúde no Fórum Regional de Municípios Saudáveis, realizado em 1997, no município de Vargem Grande Paulista, Estado de São Paulo, que reuniu vários municípios e contou com a presença de prefeitos e secretários da saúde. Houve também a participação de técnicos da cidade na Oficina sobre Cidades Saudáveis da ABRASCO, no Congresso Brasileiro de Saúde Coletiva, ocorrido em agosto de 1997. A idéia foi apresentada à prefeita da cidade, que promoveu um fórum de secretários municipais, em que seriam debatidos os problemas da cidade. A área de saúde relacionou os problemas e seus determinantes: falta de educação, destino do lixo, e com a renda. Reforçou que os problemas não poderiam ser solucionados apenas com medicamento, médico e tecnologia, sendo necessário, para isso, um trabalho articulado. Três prioridades foram elencadas: saúde, educação e saneamento básico. A partir daí, vários projetos foram implementados nessas três áreas.

O trabalho conjunto entre as secretarias é avaliado como fundamental, porém é ainda um desafio no município. Existem dois projetos com enfoque intersetorial: o de geração de renda e emprego, entre os pequenos produtores da cidade, que objetiva a implantação de uma agro-indústria Outro é o de educação ambiental, desenvolvido por várias instituições, como a Secretaria de Obras, Secretaria da Indústria e Comércio, Secretaria de Urbanismo, Secretaria da Saúde e Secretaria da Educação.

As avaliações iniciais denotam que houve maior conscientização da população em relação aos problemas e possibilidades de encaminhamentos de soluções. Na área de saúde, reduziu-se a mortalidade infantil, houve diminuição de internamentos e aumento de cobertura vacinal. Na área ambiental, já se começa a perceber melhorias em relação ao recolhimento do lixo. O aterro sanitário que começa a ser implementado fez com que houvesse uma diminuição do número de moscas, um sério problema na cidade em decorrência da cultura de fumo.

As parcerias citadas são as ONG's, que agregam produtores rurais e aquelas que trabalham com crianças e adolescentes, as secretarias municipais, o setor privado e as associações de bairro. $\mathrm{O}$ apoio técnico advém da Universidade Federal de Alagoas, além das secretarias de Estado. 


\section{FLEXEIRAS}

A cidade de Flexeiras está localizada na zona da mata do Estado de Alagoas,a $65 \mathrm{Km}$ da capital Maceió, e possui 12 mil habitantes (62,5\% na zona rural e 37,5\% na zona urbana). O primeiro contato que o município teve com esta proposta se deu no I Congresso de Secretários Municipais de Saúde das Américas, ocorrido em Fortaleza, em 1995, onde técnicos canadenses da cidade de Quebec discorreram sobre os projetos Municípios Saudáveis. Posteriormente, no I Encontro Nacional de Secretários Municipais de Saúde, realizado no Ceará, tomaram contato com a proposta de trabalho na perspectiva de Municípios Saudáveis, realizada no Estado do Paraná.

Mesmo após a realização de uma avaliação socioeconômica sanitária, da estruturação da Secretaria da Saúde e implementação da municipalização das ações, observou-se que a situação sanitária do município permanecia a mesma, ou seja, a mudança da realidade de saúde não dependia apenas da organização da atenção básica. A saúde dependia de outros setores. De início, esta proposta foi discutida no Conselho Municipal de Saúde, e um projeto de intenções elaborado foi encaminhado para a Organização Pan-Americana da Saúde. Algumas das ações propostas neste projeto foram implementadas e os problemas solucionados, como o trabalho de limpeza e retirada de lixo na área do Rio Jitituba, que demandou o envolvimento da Secretaria de Administração, Secretaria de Assuntos Sociais, Programa de Agentes Comunitários. Outra ação foi desenvolvida junto à área de educação para diagnosticar as crianças fora da escola, aumentar o número de crianças matriculadas e investir na qualidade do ensino, buscando diminuir a evasão e a repetência.

A população participa por meio de Conselhos, representando seus pares, sendo que os conselhos existentes são: Saúde, Educação, de Alimentação, da Ação Social, da Criança e do Adolescente, que se reúnem uma vez a cada mês para discutir as necessidades e traçar planos de ação.

Alguns avanços podem ser sentidos: o acesso à saúde pública está garantido e houve melhoria ambiental com a retirada do lixo. A ação integrada ocorreu, embora esteja se dando informalmente, sem qualquer planejamento prévio.

As parcerias referidas são a UNICEF, a Universidade Federal de Alagoas, a Secretaria Estadual de Saúde e a Secretaria Municipal de Saúde de Maceió.

Em abril de 1999, a cidade promoveu sua II Conferência Municipal de Saúde, Flexeiras passo a passo para se tornar um Município Saudável, com a participação de 260 pessoas, dando continuidade à discussão de implantação de ações na perspectiva do ideário de Municípios Saudáveis.

\section{Estado do Paraná}

\section{CURitiba}

Curitiba, capital do Estado do Paraná, possui cerca de 1.500.000 habitantes. Desde os anos de 1940, a cidade tem experimentado planos de urbanismo. A tradição de planejamento urbano na cidade é muito grande e foi fortalecida nos anos de 1970, com gestões públicas sucessivas que trabalharam nessa linha de ação. Desde o final da década de 70 , a cidade já experimentava a regionalização de serviços e o trabalho integrado em áreas sociais, como as da saúde e da educação. Nos anos de 1990, o setor da saúde já tinha um processo avançado de regionalização, e a vigilância à saúde já era praticada de forma bastante intensa, com tentativas de implementar ações intersetoriais. Esse trabalho procurou estar direcionado na perspectiva de identificação de problemas locais com a participação da sociedade nos conselhos locais.

Em 1994, um técnico canadense visitou a cidade e fez algumas exposições sobre a proposta de Cidades Saudáveis. Um encontro foi realizado nesse mesmo ano, IV Encontro de Saúde Coletiva e I Encontro de Saúde Cidade de Curitiba, em que se discutiram amplamente os conceitos e a possibilidade de Curitiba realizar-se como uma Cidade Saudável. Surge daí a idéia de criar a Agência Curitibana de Qualidade de Vida, que teria uma composição intersetorial e interdisciplinar e, ao mesmo tempo, seria uma instância de avaliação, responsável pelo monitoramento da cidade saudável. 
Esta proposta não se viabilizou, mas contribuiu para consolidar as bases teórico-metodológicas para a implementação dos princípios delineados para Cidades Saudáveis na gestão urbana.

O fato de haver estreita relação da saúde da cidade com o meio urbano foi um dos motivadores desta discussão. Além disso, trabalhar com uma proposta que pudesse romper com o setorial e ser assumida como uma proposta de gestão pública integrada parecia ser um avanço.

Atualmente, Curitiba faz um trabalho que visa fortalecer o planejamento intersetorial através da implantação de uma estrutura matricial para elaboração e gerenciamento de projetos estratégicos de governo. Inicialmente um desses projetos era o Projeto Cidade Saudável. Após discussões, chegou-se à conclusão de que este não se constitui em um projeto, e muito menos é responsável pelo funcionamento do setor de saúde, incluindo a assistência à saúde. Dentro desse universo, foi pensado um recorte que privilegiasse a variável comportamental, estilo de vida. Este projeto passou a denominar-se Projeto Cidadão Saudável, que pretende relacionar saúde, estilo de vida e meio ambiente, por meio de divulgação sistemática de informações e de proposição de práticas saudáveis incorporadas ao cotidiano das pessoas.

Muitas agendas ou movimentos encontram, em Curitiba, um cenário para seu desenvolvimento: Cidades Saudáveis, Agenda 21, Millenium, Imagine Chicago. No momento atual, um estudo está relacionando os objetivos desses movimentos, preocupado especialmente com a articulação das diretrizes e ações, muitas delas comuns, como a participação da população, o combate à desigualdade social, a informação, a educação, entre outros.

A participação de organizações da sociedade é o aspecto frágil do processo, uma vez que toda essa discussão esteve centrada na administração pública, que tomou para si a responsabilidade de definir políticas públicas. A área de saúde envolveu outros setores da sociedade através dos conselhos locais. No entanto, as organizações sociais nunca tiveram um papel decisivo na tomada de decisões. Alguns projetos de governo tiveram participação da sociedade no levantamento de necessidades, mas esta participação não se deu de forma integrada, desde o início dos projetos.

No intuito de envolver a população em projetos de construção de uma imagem de cidade do futuro, está sendo proposta uma metodologia baseada no Imagine Chicago, que parte de um levantamento do imaginário da população sobre a cidade que gostariam de ver construída no próximo milênio.

São também relatados 3 tipos de mecanismos utilizados pela prefeitura para atender às demandas da população. O primeiro, é o Prefeito no Bairro, em que o prefeito visita as regionais e sub-regionais e se reúne com as lideranças locais, fazendo prestação de contas. No segundo momento, o prefeito despacha duas tardes por semana nas Ruas da Cidadania, com lideranças locais. O terceiro, é o Tele-Cidadão, que é uma pesquisa continuada realizada por telefone.

A partir de 1997, foram criados grupos matriciais, para se ter uma ação mais abrangente envolvendo os vários setores da instância municipal. Hoje, são 23 projetos estratégicos, que foram definidos por meio de um planejamento estratégico situacional simplificado. São eles: BR Cidade, Linhão do Emprego, Empório Metropolitano, Plano Mil, Saneamento Bairro a Bairro, Vila Olímpica do Paraná, Cidadão em Trânsito, Segurança, Centros de Bairros, Digitando o Futuro, Cidadão Saudável, Coração Social, Ahú Cabral, Eixo Barão- Riachuelo, Zoneamento e Uso do Solo, Portão Cultural, Patrimônio Cultural, Sistema de Indicadores para Gestão Municipal, Revivendo Curitiba, Segurança no Trânsito, Modal elétrico/estacionamento, Rebouças, Habitação e El Niño. A gestão desses projetos foi organizada em 3 níveis, Nível 1: prefeito e coordenadores de projeto; nível 2: coordenadores de cada projeto e os gerentes de operação; nível 3: gerentes de operação responsáveis por ações. O grupo de apoio é composto pelo IMAP ( Instituto Municipal de Administração Pública) e pelo IPPUC ( Instituto de Pesquisa e Planejamento Urbano de Curitiba) e pelo gabinete do prefeito.

O projeto Cidadão Saudável é um dos projetos que está envolvendo a comunidade. O objetivo básico do projeto é que a população construa sua saúde. O que se tem discutido é que não basta a mudança de hábitos e comportamentos para alcançar saúde e que só vai haver uma mudança comportamental se o ambiente propiciar ao indivíduo essa condição. Este projeto é entendido como uma proposta de gestão pública e de compartilhamento entre governo e sociedade, baseado no ideário Cidade Saudável. 
Foram realizados contatos com diversos setores da administração pública, como Secretaria da Saúde, da Educação, Fundação Cultural de Curitiba, Secretaria de Esporte e Lazer, Secretaria de Meio Ambiente, e preparadas, em conjunto, propostas intersetoriais. Atualmente, há 5 operações propostas. Este projeto, além de uma série de ações específicas, deverá desenvolver a outorga do selo do Cidadão Saudável às pessoas, entidades e grupos sociais ou empresas que estejam desenvolvendo ações ambientais, de promoção da saúde e de melhoria de qualidade de vida. Outra proposta ligada a este tema é a realização de um programa de rádio, chamado Rádio Saudável, que insere dicas sobre atividades físicas relacionadas com a saúde, nutrição etc., na rádio $\mathrm{AM}$, nos programas de grande audiência, que tem maior penetração na periferia,

Existem outros projetos que não são desenvolvidos sob a "marca” Cidade Saudável, mas que trabalham numa perspectiva de melhoria de qualidade de vida, como a reciclagem do lixo, que já foi absorvido pela população no seu dia-a-dia, a preservação de áreas verdes, projetos de experimentação de outros combustíveis com vistas à diminuição da poluição do ar etc. Vários projetos têm trabalhado também na perspectiva intersetorial, de melhoria de qualidade de vida. O projeto Linhão do Emprego, por exemplo, tem uma abrangência de 350 mil habitantes, criou dez pólos de geração de atividades econômicas, urbanizando toda uma área e protegendo a linha de alta tensão da COPEL.

Tem havido uma preocupação em definir indicadores que possam medir a qualidade de vida na cidade. Nesse sentido, foi implementado o Projeto Indicadores de Qualidade de Vida em Curitiba, que aborda os diferenciais inter-urbanos, considerando saúde, educação, habitação, renda e transporte. Uma primeira avaliação foi realizada em 1995. Esta metodologia de acordo com técnicos, apresentou problemas por incorporar indicadores de serviço juntamente com indicadores de processo, indicadores de impacto, indicadores de estrutura. Os dados, no entanto, tem mostrado que a cidade tem tido melhorias significativas em relação à qualidade de vida. Houve redução da mortalidade infantil, de 20/1000 nos últimos 5 anos, passou para 16/1000. A área verde de Curitiba é de $52 \mathrm{~m} 2$ por habitante, em termos de área urbana é a maior do país. A cidade possui $200 \mathrm{Km}$ de ciclovias e 18 grandes parques, distribuídos também na região periférica. A cobertura de água é praticamente total e até o ano 2000 espera-se que $80 \%$ da cidade terá esgoto coletado e tratado. Na área de educação, a cidade está engajada em programas como Toda Criança na Escola, Classes de Aceleração, entre outros. Há um extensa rede de serviços sociais, saúde, creches, educação.

No momento, outras metodologias de avaliação, e outros indicadores mais específicos vêm sendo pesquisados, como os de violência e meio ambiente, visando comparar dados de 95 com os atuais.

A iniciativa privada tem se agregado a alguns projetos, porém esta parceria é ainda tênue e pontual. Outros parceiros são destacados: comunidade, diversas instituições públicas, Associação Médica do Paraná, Associação Brasileira de Qualidade de vida, Associação Brasileira de Indústrias Alimentícias e Alternativas, Universidades e SEBRAE.

A comunicação é considerada uma questão crucial em todos os projetos estratégicos e tem sido levantada como um nó crítico. Trabalhar a comunicação nas diferentes abordagens tem sido uma grande preocupação: comunicação de massa, comunicação direta com a população, comunicação no interior da instituição. No sentido convencional, tem-se trabalhado com a mídia, os jornais e a Internet. Especificamente no projeto Cidadão Saudável, estão se criando instâncias, pontos descentralizados para que ocorra uma comunicação direta, cujo enfoque seja a informação, para as definições de políticas institucionais. Estas informações referem-se à percepção da população sobre os problemas e sugestões de ações a serem realizadas.

Curitiba conta com financiamento para seus projetos do Banco Mundial, do BID, sendo que alguns dos projetos específicos, como o Cidadão Saudável não têm ajuda externa, outros, como o Linhão do Emprego, têm financiamento nacional e internacional (BNDS).

No projeto "Cidadão Saudável" está sendo prevista a instituição de parcerias com associações. O apoio técnico para o projeto na linha Cidade Saudável tem vindo do Canadá e da Europa, especialmente da Inglaterra, que tem fornecido subsídios na discussão e elaboração nos aspectos conceituais e metodológicos. No processo de construção do "Sonho de Curitiba", tem havido colaboração técnica americana, já que este projeto foi baseado no "Imagine Chicago". Além desses, são também citados o Instituto Brasileiro de Qualidade e Produtividade, a Fundação Getúlio Vargas e a PUC. 


\section{ChOPINZINHO}

Chopinzinho está localizada no Sudoeste do Estado do Paraná e possui uma população de 20 mil habitantes, distribuída numa área de $900 \mathrm{Km} 2$, sendo $62 \%$ na zona rural e $38 \%$ na zona urbana. Em Chopinzinho, o projeto Município Saudável teve início em março de 1995 quando o Secretário da Saúde do Estado do Paraná, Dr. Armando Raggio, apresentou a proposta para o município em uma reunião, com a presença do Dr. Norberto Martinez (Diretor da OPAS no Brasil). A equipe do município interessou-se pela proposta, principalmente, porque trazia em seu bojo os mesmos pressupostos de incentivo à participação popular e à ação intersetorial que já eram privilegiados no trabalho do município na área da agricultura.

Assim como outras experiências que aconteceram no Estado do Paraná, Chopinzinho também teve o apoio inicial de técnicos da Secretaria de Estado da Saúde. Em várias reuniões e eventos ocorridos em outras regiões do Estado, Chopinzinho teve a oportunidade de apresentar sua experiência, o que auxiliou na sua consolidação.

O trabalho na área da agricultura já contava com o envolvimento de diversas associações da sociedade civil, tais como: associação de produtores rurais, mulheres rurais, clubes de mães, associação comercial, professores da rede pública local, Rotary Clube do Brasil, APAE, outras associações, cooperativas e sindicatos.

Foi referido que o trabalho de aglutinação dos grupos foi difícil no início, pois existia uma resistência natural para o trabalho conjunto e compartilhado e, também, pouca vontade de dividir o poder que cada grupo já detinha.

As primeiras iniciativas estiveram relacionadas com a continuidade das ações na área da agricultura que já vinham sendo desenvolvidas anteriormente ao projeto de Município Saudável. Um passo importante foi conseguir que o Governo Federal determinasse, por meio de decreto, que todos os municípios do Brasil devessem ter Conselho de Desenvolvimento Rural, garantindo a participação da sociedade nas decisões das questões agrícolas. Outro aspecto importante foi o PRONAFE, que é o programa de renda familiar. A criação do Conselho Municipal de Desenvolvimento Rural no município foi fundamental para a implantação de várias ações que objetivam a organização dos produtores rurais e de programas de geração de renda que favoreceram a fixação de aproximadamente $60 \%$ da população no campo, aliviando a velocidade do êxodo rural na direção da região urbana. Neste processo, houve uma reconversão das propriedades muito grandes e discussão sobre o plantio de culturas alternativas que garantissem mais renda para os produtores. Outra iniciativa relacionada com a produção agrícola é o Programa de Readequação de Estradas, que facilita o escoamento da produção. Atualmente, os produtores estão organizados em associações que reúnem os agricultores localizados em comunidades próximas e que por afinidade de ações ou tamanho de propriedade ou grau de parentesco, reúnem-se para discutir as ações relacionadas com a agricultura, que incluem nas pautas das reuniões educativas ou de capacitação para melhorar o desempenho dos trabalhadores rurais e sua qualidade de vida. O canal de comunicação entre estas associações é a prefeitura é o Conselho Municipal de Desenvolvimento Rural.

Outros programas desenvolvidos foram: Programa de Hipertensão Arterial, que foi iniciado junto ao Clube da Terceira Idade; Programa de Prevenção da Diabetes, Programa de Combate à Mortalidade Infantil, Programa de Planejamento Familiar, vinculados ao programa Materno-Infantil.

Especificamente em relação às ações da área de saúde, que foi um dos setores fundamentais para a implantação do projeto, foram desenvolvidas as seguintes ações: postos de vacina volantes, prevenção e vigilância à saúde relacionadas ao tétano, hepatite, rubéola e ao controle de agrotóxicos.

$\mathrm{Na}$ área da habitação foi desenvolvido o projeto de desfavelamento, com a remoção de famílias que viviam em condições muito precárias em terrenos invadidos, sem condições sanitárias adequadas. Com este intuito, foi organizada uma Cooperativa Municipal de Habitação, que permitiu a transferência desta população para locais com estrutura urbana mínima de saneamento básico, calçamento e energia elétrica. Esta Cooperativa é composta pela população que necessita destes serviços, e que atua em um caráter de associação, e por funcionários públicos municipais que participam com o respaldo técnico e administrativo necessário. 
Também foi criado o Conselho do Desenvolvimento Econômico, que aglutina representantes da Associação Comercial local, do Conselho Municipal do Trabalho, do Conselho Municipal do Desenvolvimento Rural e representantes da prefeitura. Seu objetivo é fomentar e fortalecer os industriais do município, para que ocorra um aumento da produção e do comércio na região. Um dos programas criados em função de demandas deste Conselho foi "Barracões para a Produção em Comodato", que incentiva indústrias que queiram se implantar na cidade e cuja produção seja considerada adequada e necessária para a região. Elas recebem um local para se instalar sem pagar aluguel pelo período de sete anos. Também existe parceria com o SEBRAE, que mantém um posto avançado junto à Associação Comercial, para oferecer informações aos empresários locais. Existe, também, parceria com o Departamento do Trabalho e com a Secretaria do Emprego para a intermediação de mão-de-obra, informações sobre os recursos financeiros do Fundo de Amparo ao trabalhador.

Na área da Promoção Social, os programas desenvolvidos também têm interface com os demais departamentos da prefeitura. Há programas para o acompanhamento da gestante e do recémnascido, o Programa Brasil Criança Cidadã, que atende cerca de 100 crianças no Centro Educacional e de Ocupação da Criança e do Adolescente, no período contrário ao da escola: há o Sistema Creche, até com Creche Rural: o Programa Piar no Karatê, Da Rua Para A Escola: o Programa da Infância e da Adolescência Indígena, o Centro Regional de Profissionalização e o programa Casa da Família, dirigido aos idosos.

De acordo com os técnicos da prefeitura local, esta estratégia de trabalho indica resultados em várias áreas:

- melhoria muito grande do nível educacional, em conseqüência da implantação de núcleos de ensino com equipes completas em cada localidade (diretor, vice-diretor, professores, secretários, merendeiros) e recursos materiais e físicos (informatização, datilografia, capacitação de professores e adequada área física). Este projeto também garantiu a abertura para a participação da comunidade, principalmente dos pais e professores.

- melhoria no meio ambiente, principalmente no campo, em relação às queimadas e à proteção da mata na beira dos rios para a proteção da erosão. Na cidade, houve maior conscientização quanto à manutenção de praças.

- desenvolvimento econômico: incentivo à produção agrícola. Um dos instrumentos foi a valorização da "retirada da nota fiscal", objetivando o retorno do ICMS para o município. Houve um aumento da produtividade, de $25 \%$ em média.

- políticas intersetoriais: foram desenvolvidas muitas ações que fizeram com que os setores trabalhassem juntos, principalmente saúde, educação e agricultura.

Os parceiros referidos são: os conselhos comunitários e municipais, o poder público que sempre tem uma maior participação que a iniciativa privada, organizações e associações civis de forma geral. Cada departamento, dependendo do projeto que desenvolve, possui determinados colaboradores. No caso da Cooperativa Municipal de Habitação: a Caixa Econômica e outras entidades privadas colaboram com recursos; também os departamentos de saúde e educação, com a organização de cursos profissionalizantes, de alfabetização e conscientização social dirigido para esta população. A idéia não é só construir casas, mas, também, reabilitá-los para poderem ser mais atuantes nas suas vidas. Outras parcerias são com a SANIPAR, para a rede de água, e com a COPEL, para a energia elétrica. Existe também a APMI (Associação de Proteção Maternal na Infância) que faz o cadastramento das famílias da cidade para o desenvolvimento de ações nessa área.

Existem duas emissoras de rádio locais, que divulgam todos os programas do município, e os próprios departamentos informam a comunidade em reuniões, nos bairros. A divulgação também acontece por meio da imprensa escrita e pelos jornais locais.

O Projeto, em si, não visa a obtenção de recursos externos. A idéia é de que o município deve viabilizar os recursos, buscando-os no próprio município, ou no governo estadual ou federal. No caso de Chopinzinho, existe a avaliação de que muitos dos recursos foram conseguidos graças ao empenho da equipe da prefeitura local. 


\section{ESTADO DO CEARÁ}

\section{FORTALEZA}

Fortaleza, capital do Estado do Ceará, possui 2 milhões habitantes. Desde os anos de 1980, Fortaleza tem buscado caminhos para efetivar a descentralização das ações de saúde. Este movimento foi iniciado com a implantação de Distritos Sanitários, a realização de planejamento participativo e a implantação de inúmeros programas. A necessidade de um compromisso com a qualidade de vida, como condição básica para viabilizar a produção de uma sociedade saudável, foi discutida no I Congresso de Secretários Municipais de Saúde das Américas, em Fortaleza em 1995, onde foi elaborada a CARTA DE FORTALEZA, que enfatizava a importância do desenvolvimento de ações intersetoriais e descentralizadas.

A partir do ano de 1997, a Prefeitura Municipal de Fortaleza foi remodelada e passou a se reorganizar, com o objetivo de dar maior eficácia às organizações municipais e possibilitar, assim, uma vida com qualidade. Foram criadas duas secretarias que deram suporte técnico à cidade: a Secretaria de Desenvolvimento Social (SMDS) que foi criada com o objetivo de integrar as políticas sociais, planejando, monitorando indicadores, definindo prioridade, e a Secretaria de Desenvolvimento Territorial (SMDT) que foi responsável pelo planejamento e articulação das políticas de controle urbano, meio ambiente, transporte, obras viárias, obras municipais e limpeza urbana. Foram criadas, ainda, 6 Secretarias Executivas Regionais (SER), com a responsabilidade de atender a população em suas respectivas áreas de abrangência, por meio de planos integrados de geração de emprego e renda, saúde, educação, assistência social, cultura, lazer e esporte. Por meio das SERs ocorrem as relações entre o governo municipal e o cidadão.

No ano de 1997, Fortaleza recebeu técnicos canadenses, que iniciaram com os técnicos locais, a discussão sobre o estabelecimento um convênio de cooperação, o que acabou não se realizando.

\section{SOBRAL}

Sobral possui 138 mil habitantes ( $86 \%$ população urbana e $14 \%$ população rural) e localizase na zona do sertão centro-oeste do Estado do Ceará, $224 \mathrm{Km}$ distante de Fortaleza. Começou a trabalhar a proposta de Municípios Saudáveis em meados de 1997, desde a mudança de administração, de 96 para 97. Trabalhou-se um plano de governo que teve aproximação com os pressupostos delineados nos projetos Municípios Saudáveis, como a intersetorialidade, as políticas públicas como prioridade, a participação popular, a universalização das políticas públicas de saúde, educação e assistência social e a cultura. Através da Secretaria de Estado, da Escola de Saúde Pública do Ceará, num projeto de parceria com a Fundação Kellogg, o município passou a sistematizar um projeto, com a participação de organizações da sociedade civil.

Um seminário, intitulado Pensando no Futuro, reuniu mais de 80 organizações da sociedade civil organizada. Todos os segmentos da cidade, governamentais, e não governamentais discutiram o futuro da cidade. Outra participação importante refere-se aos conselhos setoriais, o Conselho de Saúde, o Conselho de Assistência Social, o Conselho de Cultura, o Conselho de Trabalho, o Conselho de Meio Ambiente. Todos esses Conselhos têm apoiado os projetos intersetoriais e também os setoriais, discutindo o setorial na perspectiva da intersetorialidade. O orçamento participativo promoveu uma grande mobilização na cidade. As plenárias trouxeram subsídios importantes para a proposta, criando, a partir delas, o Conselho do Orçamento Participativo.

Foi realizado o plano diretor, tendo como diretriz o Município Saudável. Todo o processo foi participativo, com assembléias populares, regionais e geral, tendo sido traduzido na linguagem do teatro popular, para alcançar a população e ampliar o universo de comunicação.

Uma das mais importante estratégias referidas foi ancorar o projeto por um município saudável nas escolas, entendendo a escola como promotora de municípios saudáveis, da cidadania, das políticas públicas saudáveis, dos investimentos públicos nos determinantes da qualidade de vida. Cinqüenta por cento da população de Sobral têm de 0 a 19 anos. Como se entende que o Município 
Saudável é uma idéia força que significa a construção de uma nova consciência de vida, considera-se que é importante investir na juventude.

Alguns avanços puderam ser observados nas áreas de saúde, educação e meio ambiente. No início de 1997, apenas $7 \%$ da cidade possuía saneamento, o que hoje, se estendeu para $40 \%$ do município. Do ponto de vista do urbanismo, houve também um avanço importante nos pantanais da cidade, um deles foi eliminado, e a população residente transferida para casas construídas em regime de mutirão, que possuem toda infra-estrutura urbana. Outro pantanal está sendo saneado, e outro está em processo de eliminação. Na área da educação houve ampliação de $50 \%$ das vagas no município, de 8 mil para 16 mil vagas; houve melhorias do ponto de vista pedagógico e concursos para professores.

Inexistia, no município, uma saúde pública municipal. Em um ano, a cidade entrou na gestão plena da saúde, o que ocasionou um salto qualitativo muito grande. Outro aspecto importante referido na área de saúde foi a implantação do Programa de Saúde da Família.

Para a equipe que vem trabalhando no gerenciamento do projeto, mais importante que os resultados, são os processos, que têm possibilitado pensar novas formas de gestão para a cidade, com participação da população.

Alem disso, todos os projetos desenvolvidos, hoje, são realizados em parceria com a comunidade. São referidos os seguintes parceiros: a igreja, os clubes de serviços e entidades empresariais. Ações de comunicação não têm sido desenvolvidas visando o Município Saudável. Há, no entanto, uma preocupação de sistematizar melhor essa idéia.

A administração tem utilizado o rádio, outdoors e o teatro, para divulgar e discutir com a população os projetos e ações desenvolvidos localmente. A Escola de Saúde Pública do Ceará tem contribuído, dando apoio técnico.

\section{CRATEÚS}

A cidade de Crateús, criada em 1911, situa-se a 365 Km de Fortaleza e possui cerca de 66 mil habitantes. O projeto Municípios Saudáveis, em Crateús, teve inicio em dezembro de 1997, quando o município procurou a Escola de Saúde Pública do Ceará, para discutir a proposta de trabalho de um projeto de saúde que contemplasse outros setores, e objetivasse a melhoria na qualidade de vida. A capacidade de trabalho do município, aliada à vontade política, tem sido, desde então, motivadores desse processo. Como Crateús situa-se numa das regiões mais inóspitas e pobres do Estado do Ceará, qualquer iniciativa deveria incluir ações criativas, de mudança da forma de gestão da cidade. A cidade é uma sede regional, para onde convergem cerca de 12 municípios que possuem sérios problemas sociais na área da educação, da saúde. Como Crateús não pode atender a essa demanda toda, procurou se organizar, tentando mostrar aos municípios vizinhos que é possível fazer uma administração diferente.

Do contato com a Escola de Saúde Pública do Estado do Ceará, começou-se a difundir a idéia de trabalho na linha de Municípios Saudáveis. O município foi inicialmente dividido em 21 áreas de mobilização popular e foram criados 21 comitês populares, envolvendo 300 agentes de mobilização. Foram realizados vários seminários, primeiro para os técnicos, depois para o pessoal da prefeitura, e em seguida, nos distritos comunitários, culminando no I Seminário de Crateús Saudável, que contou com a presença de 300 pessoas.

Foram realizadas 26 conferências, em distritos e bairros, em que o projeto Município Saudável foi apresentado, e discutidas as condições objetivas de Crateús para sua implantação e as formas de participação da população nesse processo. Não foi encontrada rejeição por parte da população, pelo contrário, o projeto teve uma aceitação muito rápida. Foi expressiva essa participação. Hoje, cerca de 300 pessoas trabalham para construir a Crateús sonhada a partir da Crateús real (diagnóstico). O diagnóstico não é apenas uma análise da situação de problemas, mas também um resgate histórico, no sentido identificar os pontos fortes da comunidade, suas peculiaridades, e suas potencialidades.

Em cada bairro, foi formalizado um Comitê local, formado por moradores, com representantes de estudantes, professores e mães. A idéia foi transformar a escola num agente de 
transformação, um local de promoção da saúde. Além desses, atores já mencionados, do Comitê local participaram lideranças comunitárias, representantes de idosos, a igreja, representantes de sindicato. Cada comitê tem um supervisor. Esses comitês se reúnem para debater a realidade social, cultural e econômica da localidade.

Após a fase diagnóstica, os problemas e o poder de resolução da comunidade e do poder público passaram a ser discutidos. Algumas ações já estão sendo encaminhadas, especialmente em relação à escola.

O movimento tem propiciado maior colaboração entre os membros da comunidade. Os comitês aproximam as pessoas e resgatam questões como a cidadania. Além disso, reunir pessoas em torno de um objetivo comum, que é a melhoria da qualidade de vida, torna a convivência mais harmônica. O bairro passa a ter espírito de equipe, já que a discussão está voltada para o coletivo e não para o individual.

O projeto não é uma proposta da Saúde, ou da Educação. O coordenador tem uma visão ampla do município e isso vem suscitando uma verdadeira intersetorialização. Hoje as ações não se restringem a áreas específicas, mas são ações integradas de um Município Saudável.

De acordo com os depoimentos, ainda é cedo para saber o impacto do projeto, já que este se encontra em fase de implementação. Pode-se observar, no entanto, um avanço em relação à mobilização da comunidade.

O principal parceiro do governo municipal referido é a comunidade. O apoio logístico é da Escola de Saúde Pública do Estado do Ceará, que presta cooperação técnica, em convênio com a Fundação Kellogg. Este convênio tem duração de 3 anos. No primeiro ano, estão sendo criados mecanismos que assegurem a implantação do projeto. Esta parceria, efetivada em meados de 1997, através de um programa, Construindo Novas Práticas e um Novo Ensino em Saúde Pública, teve o intuito de localizar novos campos de saúde pública. Foram selecionados municípios para trabalhar questões de mobilização social, a participação popular e a promoção da saúde. Inicialmente, o trabalho começou em Sobral, com a realização de um grande seminário e a definição de um planejamento intersetorial.

Para se garantir o acesso à informação, comitês técnicos e locais têm sistematizado as informações, que são consolidadas em cartilhas. Algumas informações indicam, por exemplo, mudanças em indicadores. Essas cartilhas são distribuídas para todo o conjunto da população, para que o conhecimento da proposta não fique restrito aos formuladores e executores de políticas. Uma série de informações são repassadas por cordel, falando de algumas ações e de serviços resultantes da proposta de Município Saudável. A rádio local tem sido, também, utilizada na divulgação de informações.

\section{ESTADO DE Minas Gerais}

\section{DIONíSIO E SÃo JoSÉ Do GOIABAL}

Dionísio, com 10 mil habitantes, e São José do Goiabal, com 6 mil habitantes, são municípios vizinhos localizados a cerca de $160 \mathrm{Km}$ de Belo Horizonte, capital do Estado de Minas Gerais. Desde o ano de 1996, a Escola de Saúde de Minas Gerais/ Fundação Ezequiel Dias vem desenvolvendo uma iniciativa piloto, com o objetivo de operacionalizar ações dentro do marco conceitual do movimento por Cidades Saudáveis. Os dois municípios iniciaram o trabalho no mesmo período e tiveram processos de desenvolvimento semelhantes.

O primeiro passo foi a realização de uma sensibilização de lideranças políticas e comunitárias e a formação de dois grupos intersetoriais que foram fundamentais para o desenvolvimento da proposta: GDI - Grupo Decisório Intersetorial, também denominado de Comitê Diretivo Intersetorial ou Comitê Cidade Saudável, instância máxima de tomada de decisão, composto por diferentes segmentos da população, e o GTI - Grupo Técnico Intersetorial, de caráter executivo. Além desses, foi criado o GA - Grupo Assessor (técnicos da Escola de Saúde de Minas Gerais), responsável pelo processo de elaboração de um Plano de Ação Intersetorial e Participativo, por meio de assessoria técnica e metodológica. 
Após a sensibilização inicial e a formação dos grupos, foi realizado um trabalho de Estimativa Rápida para o levantamento da realidade local e a definição de problemas prioritários a serem abordados pelo Projeto. Nos dois municípios, as prioridades selecionadas foram água, lixo e esgoto.

Outra questão que mereceu destaque em decorrência do Projeto foi a elaboração do orçamento municipal, que suscitou um processo de discussão com a comunidade resultando em uma proposta de orçamento para o ano de 1999, que deverá ser encaminhada para a Câmara de Vereadores.

Desde o início, houve participação de organizações governamentais e não governamentais de entidades como o Parque Florestal da Rio Doce, que pertence ao Instituto Nacional das Florestas, representantes de uma Companhia de Reflorestamento de uma Siderúrgica local, de comunidades da zona rural, da associação policial e da igreja protestante.

Até o momento ainda não estão sendo medidos os impactos. No entanto, alguns resultados, já foram alcançados: mobilização e participação de diferentes setores do município na identificação de problemas, na priorização e discussão de soluções; envolvimento da prefeitura no acompanhamento e desenvolvimento do trabalho; o projeto estimulou a Coordenação do Grupo Técnico a buscar alternativas para soluções de problemas locais; nos dois municípios está se iniciando o planejamento de campanhas que discutem a problemática de saúde, educação e ambiente; em São José do Goiabal o projeto propiciou a discussão do problema do lixo nas escolas. A Prefeitura local tem desenvolvido ações para organizar a coleta seletiva do lixo e está construindo uma Usina de Reciclagem e Compostagem de Lixo. Estão sendo construídas fossas sépticas e tem havido melhoria no sistema de água. Em Dionísio, houve melhoria da coleta do lixo. A prefeitura iniciou ações voltadas ao abastecimento de água e construção de fossas sépticas.

O momento de divulgar o que está sendo realizado é feito em encontros com a população, especialmente em reuniões do Grupo Decisório Intersetorial.

Com o objetivo de criar mecanismos de comunicação mais eficazes, foram feitas reuniões com a comunidade, o rádio também é utilizado. No entanto, esta é uma questão que está sendo discutida com cuidado

A Fundação Ezequiel Dias, à qual a Escola de Saúde de Minas Gerais está vinculada, financia o apoio técnico, e recursos do Ministério do Planejamento estão sendo direcionados à área de saneamento. Recursos da Caixa Econômica Federal também estão sendo liberados para essas obras.

O Grupo Assessor é constituído por técnicos da Escola de Saúde de Minas Gerais que oferecem apoio técnico e metodológico. Tem como tarefa sensibilizar as autoridades locais, aglutinar os setores da sociedade local e junto com esses atores elaborar um planejamento estratégico situacional. 


\section{AS EXPERIÊNCIAS DE JUNDIAÍ E MACEIÓ COM ENFOQUE NOS PROCESSOS PARTICIPATIVOS E DECISÓRIOS}

\section{INTRODUÇÃO}

As duas cidades, Jundiaí e Maceió selecionadas para estudo de caso, possuem características bastante diferenciadas com relação ao desenvolvimento de projetos na perspectiva do ideário por Cidades Saudáveis (figura 3).

Não foi objetivo deste trabalho proceder a uma comparação entre os projetos e os processos participativos inscritos nessas políticas. No estudo de caso, cada caso é um caso, e apresenta uma singularidade que lhe é própria. Observa-se que a dimensão e a diversidade do sistema social brasileiro determinam uma multiplicidade de situações

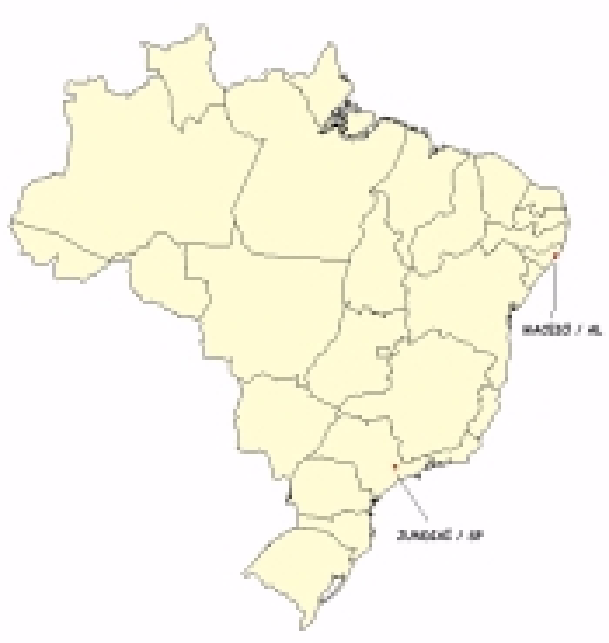

Figura 3: Mapa do Brasil mostrando a localização das cidades de Jundiaí e Maceió diferenciadas. Retratamos a realidade de duas cidades completamente distintas, localizadas em duas regiões diferentes: Jundiaí apresenta-se com um dos melhores índices de qualidade de vida do Estado de São Paulo, e Maceió, capital de Alagoas, um dos Estados brasileiros mais carentes do país. Também se diferenciam as formas de envolvimento das cidades nesse processo e de condução dos projetos visando a para a definição de ações com vistas à construção da Cidade saudável, no caso de Jundiaí, e de Comunidades Saudáveis, no caso de Maceió.

Neste capítulo, pretende-se identificar o processo histórico de inserção das cidades ao movimento por Cidades Saudáveis, bem como esclarecer e analisar os processos participativos em cada uma das cidades separadamente. Esta análise será realizada por meio das representações dos atores envolvidos nos projetos e dos documentos que foram produzidos no decorrer do processo de implantação dos projetos. São aqui retratados, também, os materiais impressos produzidos na cidade de Jundiaí, que tiveram o objetivo de dar visibilidade às ações. 


\section{A CIDADE DE JUNDIAÍ}

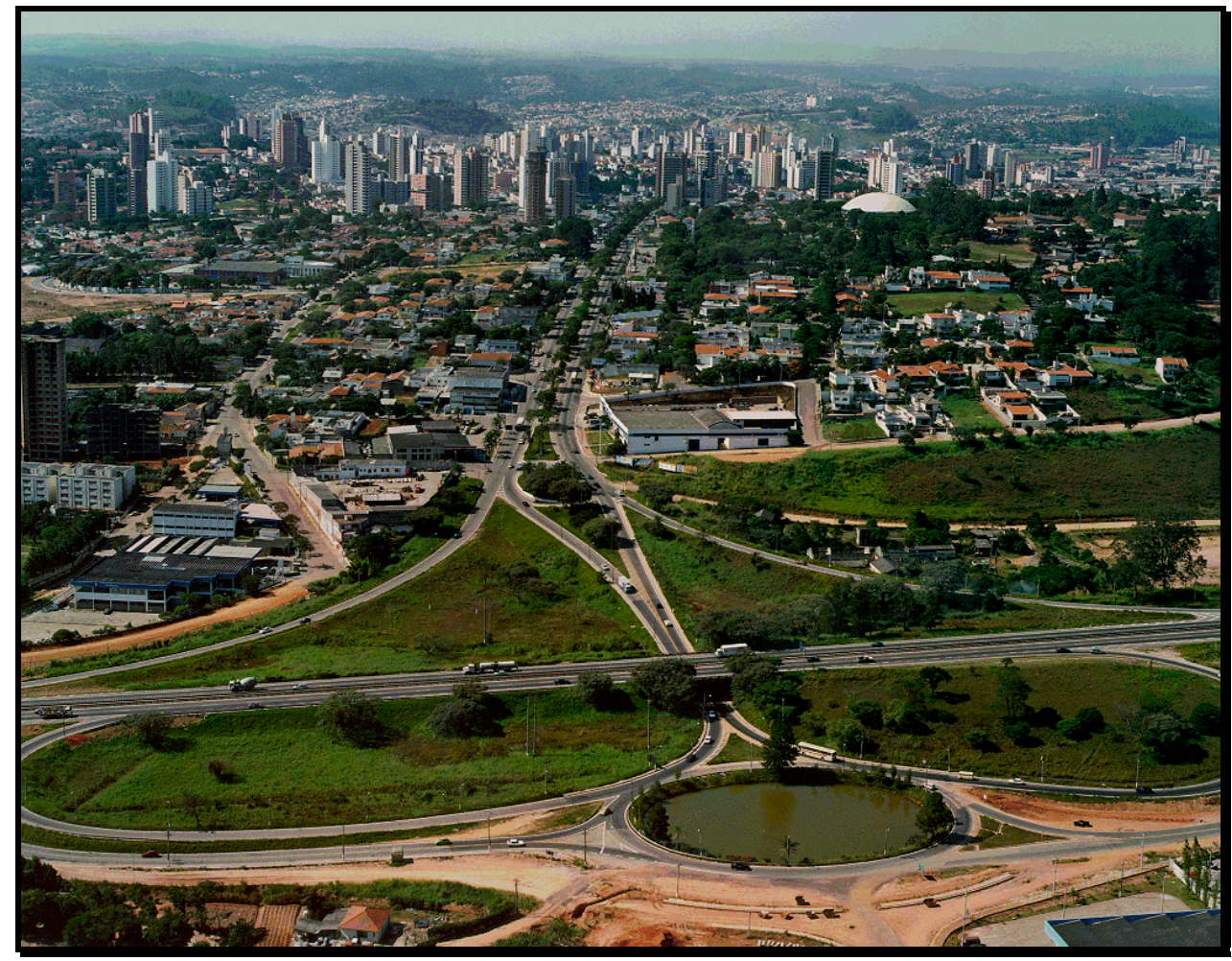

Figura 4 - Vista geral da cidade de Jundiaí

\section{História}

Os primeiros povos que habitaram a região do rio Jundiaí -Guaçu foram os indígenas, que se ocupavam principalmente da agricultura, caça e pesca. Com a chegada dos primeiros colonizadores, no início do século XVII, uma pequena povoação, situada no Vale do Tietê, deu origem a cidade de Jundiaí. De acordo com SALVADORI (1998), o nascimento da cidade está vinculado à história do movimento bandeirante, que foi ocupando as regiões e provocando a fuga dos grupos indígenas locais. Em 1655 o povoado foi elevado à categoria de vila. Nos séculos seguintes, até o início do século XIX, a economia local esteve limitada à agricultura de subsistência a ao comércio local. A cidade passa por um período de crescimento por ocasião do Ciclo do Ouro em Minas Gerais, já que se constituía em um local de passagem, um posto de abastecimento às expedições. O maior crescimento da cidade, no entanto, ocorre a partir da segunda metade do século XIX, com a produção do café, cana e algodão, com a chegada das primeiras indústrias e com a construção da Estrada de Ferro Santos -Jundiaí em 1867. O final do século XIX foi marcado pela imigração italiana, pela intensificação da cafeicultura e da industrialização, com 
destaque às indústrias têxteis. No século $\mathrm{XX}$, o processo de industrialização continuou, sendo incentivado pela inauguração da rodovia Anhanguera em 1948 e pela abertura do capital nacional ao estrangeiro. A industrialização impulsionou o setor terciário da economia, fazendo com que a cidade de Jundiaí represente, até os dias de hoje, um importante pólo regional de desenvolvimento.

\section{Perfil demográfico e infra-estrutura urbana}

A cidade de Jundiaí faz parte da bacia hidrográfica do rio Jundiaí, que ocupa uma área de $1.150 \mathrm{Km} 2$. Localizada entre as Regiões Metropolitanas de São Paulo e Campinas, a Aglomeração Urbana de Jundiai $^{19}$, de acordo com estudos do IPEA/IBGE/UNICAMP (1999), é formada pelos municípios de Cabreúva, Campo Limpo Paulista, Itupeva, Louveira, Várzea Paulista e Jundiaí, que juntos possuem 485 mil habitantes, dos quais $60 \%$ estão em Jundiaí. Caracteriza-se por ser uma região bastante industrializada e com grandes nexos de integração com as regiões vizinhas (figura 5).

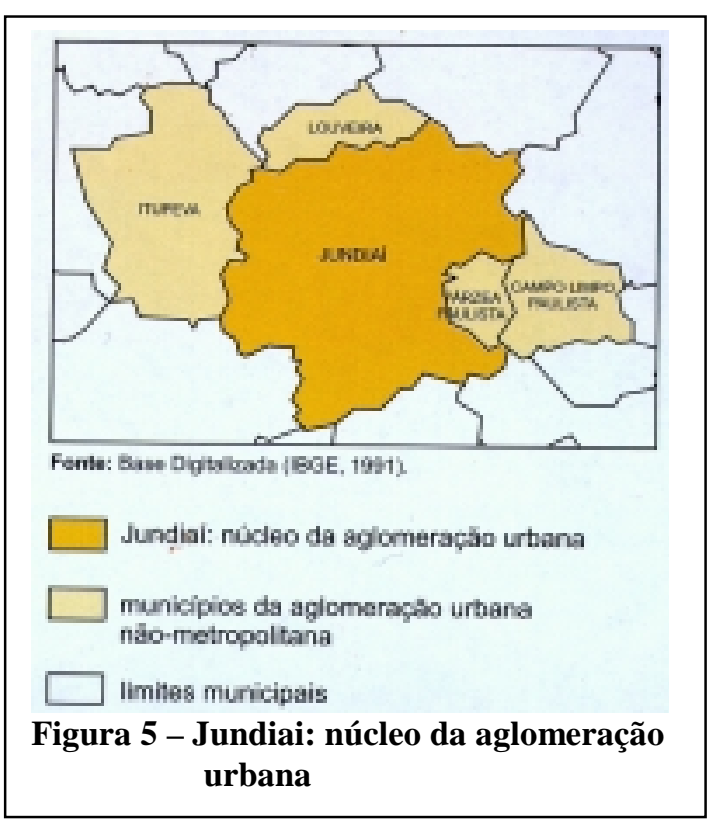

Dista $63 \mathrm{Km}$ da capital do Estado e seu território tem uma área total de 432Km2 com uma população de 294.599 habitantes que se distribui da seguinte forma: masculina 146.016 e feminina 148.583. A maior parte desta população, 46,02\%, concentra-se na faixa etária de maiores de 30 anos (SEADE 1998).

É um município basicamente urbano, sendo que os residentes na área urbana totalizam 279.616 habitantes e os da área rural 14.983 habitantes, representando uma taxa de urbanização, em 1998, de 94,91\% bastante superior à taxa apresentada no ano de 1980, 85,73\% (SEADE 1998). A maior parte da zona rural é ocupada pela

\footnotetext{
${ }^{19}$ As aglomerações urbanas são decorrentes do processo de crescimento de algumas cidades, ou conjunto de cidades, que têm provocado a formação de grandes áreas urbanas contínuas (IPEA/IBGE/UNICAMP 1999).
} 
Serra do Japi - Reserva Biológica Natural- e por pequenas propriedades produtivas que se dedicam à horticultura ( 2.462 hectares) e fruticultura (430 hectares).

A Serra do Japi possui 107 km2 de área. É reserva da Mata Atlântica tombada pelo Condephaat desde 1983 e faz parte do cinturão verde do Estado de São Paulo. Localizada entre os municípios de Jundiaí, Cabreúva, Pirapora do Bom Jesus e Cajamar, representa uma das últimas grandes áreas verdes de floresta contínua do Estado, e sofre constantes agressões com desmatamentos, caça, uso e ocupação desordenados do solo.

As estatísticas revelam que o município conta com 76.480 domicílios, sendo 70.950 situados na área urbana. A cobertura dos serviços de infra-estrutura urbana apresenta índices bastante elevados: 99,7\% dos domicílios são servidos de água, 91,1\% possuem esgotamento sanitário e cerca de $99 \%$ dos domicílios da cidade são atendidos pela coleta domiciliar de lixo. Há um aterro sanitário que funciona através de um consórcio que inclui 5 municípios: Jundiaí, Campo Limpo Paulista, Várzea Paulista, Vinhedo e Cajamar. Dois projetos de coleta e separação do lixo são desenvolvidos pela prefeitura Municipal: O Projeto Cata-Treco que realiza a coleta diferenciada de resíduo domiciliar urbano, com periodicidade semanal para cada bairro da cidade e que dá uma destinação adequada ao lixo, e o Projeto Armazém da Natureza que envolve desde a coleta do lixo reciclável seco e separação do lixo até seu encaminhamento para reciclagem nas indústrias.

Pela sua proximidade com a região Metropolitana de São Paulo a cidade tem recebido diversos investimentos em seu setor industrial. Em relação a sua atividade econômica percebe-se que, embora a maior parte das empresas seja comercial, de abrangência regional, é o setor industrial que produz o maior volume de riquezas.

Quanto ao emprego, de um total de 81 mil empregos ocupados em 1996, Jundiaí apresenta o maior número no setor industrial, 37 mil, seguido pelo setor de serviços, 27 mil e 15 mil no comércio (PMJ 1998).

Alguns índices e indicadores têm sido utilizados com o objetivo de mostrar as realidades socioeconômicas das cidades. Embora esses índices nem sempre expressem todas as dimensões da realidade, muitas delas não mensuráveis 
numericamente, podem contribuir nas avaliações das gestões e da qualidade de vida das cidades.

O Índice de Desenvolvimento Humano, que agrega três dimensões básicas: longevidade, educação e renda, revela que o IDH da cidade de Jundiaí é considerado de alto desenvolvimento 0,810, superior ao índice do Estado de São Paulo 0,787 (1991). O Índice de Condições de Vida (ICV) do PNUD, uma extensão do IDH que combina vinte indicadores básicos e os agrupa em cinco dimensões: renda, educação, infância, habitação e longevidade, mostra que a cidade de Jundiaí tem taxas mais positivas que as das cidades da micro região da qual faz parte e também em relação à média do Estado de São Paulo. Na tabela 6 abaixo, relacionamos alguns dos indicadores do ICV de 1980 e 1991.

Tabela 6 - Índice de Condição de Vida de Jundiaí e Estado de São Paulo1980-1991

\begin{tabular}{|l|c|c|c|c|}
\hline \multirow{2}{*}{\multicolumn{1}{|c|}{ INDICADOR }} & \multicolumn{2}{c|}{ Jundiaí } & \multicolumn{2}{c|}{ Estado de São Paulo } \\
\cline { 2 - 5 } & $\mathbf{1 9 8 0}$ & $\mathbf{1 9 9 1}$ & $\mathbf{1 9 8 0}$ & $\mathbf{1 9 9 1}$ \\
\hline Índice de Condição de Vida & 0,747 & 0,827 & 0,739 & 0,806 \\
\hline Esperança de vida ao nascer & 59,05 & 68,50 & 57,80 & 65,37 \\
\hline Mortalidade Infantil & 59,32 & 19,70 & 65,87 & 30,76 \\
\hline Taxa de analfabetismo & 12,2 & 7,5 & 13,7 & 9,8 \\
\hline $\begin{array}{l}\text { Número médio de anos de estudo } \\
\text { (25 anos ou +) }\end{array}$ & 4,2 & 5,8 & 4,4 & 5,8 \\
\hline Renda per capita média (SM/set 91) & 2,50 & 2,33 & 2,32 & 2,17 \\
\hline
\end{tabular}
Fonte: PNUD 1998

O trabalho desenvolvido pelo Instituto Pólis: Como reconhecer um bom governo? O papel das administrações municipais na melhoria da qualidade de vida, (SOUTO e col. 1995), ajuda a compreender a posição da cidade de Jundiaí em relação aos outros municípios brasileiros. Toma como referência o conceito de Desenvolvimento Humano, mas incorpora um maior número de indicadores para sua aferição. Compõe, assim, o Índice Municipal de 187 maiores municípios do Brasil. Jundiaí ocupa a $26^{\text {a }}$ posição $(0,821)$, e aparece no "primeiro grupo", com índices municipais mais altos. Este mesmo trabalho aponta o Índice Social Municipal dos grandes municípios de São Paulo, calculado a partir dos dez indicadores municipais de condições de vida fornecidos pelo Censo 91, agregando seis indicadores do 
$\mathrm{SEADE}^{20}$. Aqui Jundiaí ocupa a $9^{\mathrm{a}}$ posição $(0,720)$, evidenciando a posição privilegiada da cidade entre os grandes municípios paulistas. Os dois índices sintéticos que mais contribuem para rebaixar o Índice Social são os de renda $(0,625)$ e o de educação $(0,476)$. O seu maior índice sintético é o de saúde $(0,959)$, o ambiental $(0,903)$, seguido do de alfabetização $(0,728)$.

O índice de saúde de Jundiaí, que agrega o Coeficiente de Mortalidade Infantil (CMI) e leitos/mil.hab é o mais alto do Estado de São Paulo. Apesar da cidade não ter o menor $\mathrm{CMI}$, é o grande número de leitos por habitantes $(8,7 / \mathrm{mil}$ hab), que eleva o índice (SOUTO e col 1995). De acordo com o SEADE e o NIP, Núcleo de Informação e Planejamento da Secretaria de Saúde de Jundiaí, a série histórica de mortalidade infantil, indicador social dos mais sensíveis, nos últimos dez anos para o município, indica que houve uma diminuição progressiva tendo passado de $39,1 \%$ em 1980, para 18,1\% em 1998. Jundiaí conta com uma rede de atenção à saúde complexa, com inúmeros equipamentos: ambulatórios de especialidades e unidades básicas de saúde que totalizam 99 consultórios, 2 hospitais públicos com 367 leitos e 4 privados com 604 leitos. É um dos municípios habilitados em gestão semi-plena.

\section{O Projeto Jundiá Cidade SaUdável (PJCS)}

\section{Introdução}

O histórico do PJCS será resgatado por meio dos dados obtidos de diferentes fontes, que foram submetidas à triangulação: documentos, entrevistas, grupo focal. Parte dos documentos produzidos pela Prefeitura Municipal de Jundiaí foram cedidos por integrantes do Projeto, e por ex-coordenadores que o acompanharam até o ano de 1997. Pode-se observar, que muitas estratégias foram utilizadas pelo PJCS para disseminar o ideário de Jundiaí Saudável, a exemplo de reuniões nas comunidades, como na Vila Arens, seminários envolvendo técnicos e segmentos importantes da sociedade civil, seminário com os conselhos institucionais e outros. Neste levantamento chamou a atenção duas estratégias: a escolha das escolas como meio

\footnotetext{
${ }^{20}$ Os 16 indicadores que compõem o Índice Social Municipal são: Renda média, CH até 2 SM, Habit/domicílio, Cômodos, Dom. até 3 com., Água inadequada, Esgoto inadequado, Lixo inadequado, Analf. em + 15 anos, Cr c/ CH Analf, Matrícula Pré.esc, Evasão $1^{\circ}$ grau, Retenção $1^{\circ}$ g., Seg/Prim. Grau, CMI/mil N.V., Leitos /mil hab.
} 
propagador de uma concepção, e dos jornais locais, como fonte de informação para uma expressiva parcela da população.

O processo desencadeado nas escolas de Jundiaí, bem como os cartazes que foram produzidos para divulgação das atividades, foram reproduzidos neste trabalho porque ilustram as idéias, as intenções e os conceitos que foram delineando a construção do PJCS.

Não há dúvida que a imprensa local deu uma cobertura muito grande ao Projeto Jundiaí Cidade Saudável, tendo sido um meio de disseminação do ideário do Projeto, incluindo a fase inicial referente à divulgação da proposta e as etapas relativas ao desenvolvimento do Projeto propriamente dito. Os jornais locais, bem como a rádio local, de acordo com os participantes do Comitê Cidade Saudável, foram inicialmente acionados pela assessoria de imprensa da prefeitura. A partir do momento que o tema Cidade Saudável tornou-se um fato público, o PJCS passou a ser notícia e começou a ser de interesse da imprensa local.

A constatação da importância desse meio de comunicação no estabelecimento do PJCS levou a necessidade de se estabelecer uma metodologia de sistematização do material divulgado pela imprensa local, de tal forma que pudesse contribuir na reconstrução do projeto na cidade. A metodologia descrita anteriormente, definiu os Discursos do Sujeito Coletivo (DSC) que, em parte, são descritos neste histórico.

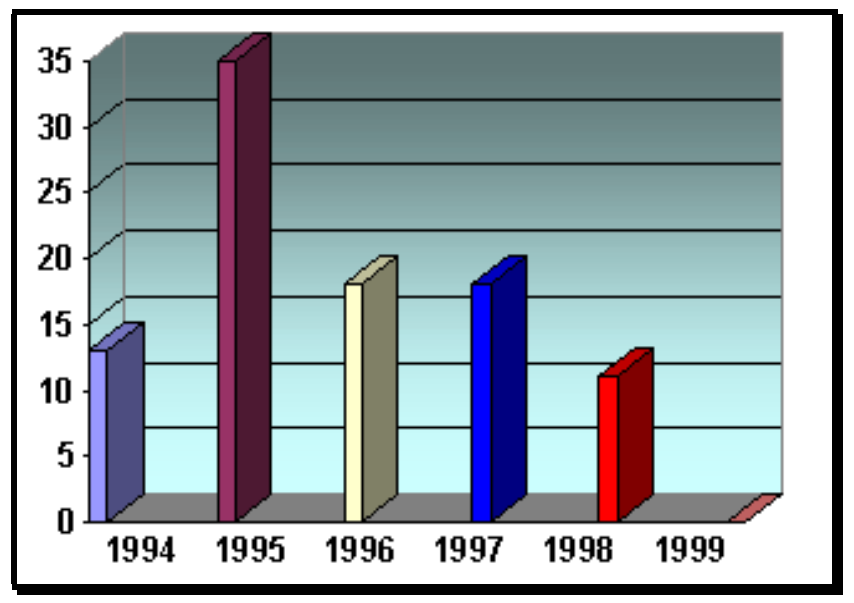

Figura 6 - Número de matérias selecionadas do jornais de Jundiaí sobre o projeto Cidades Saudáveis no período de 1994 a 1999

O volume de publicações dos jornais Jornal da Cidade e o Jornal de Jundiaí, no período de 1994 a maio de 1999, somou 93 artigos, que citam nominalmente o Projeto, distribuídos conforme mostrado na figura 6: 13 em 1994; 36 em 1995; 18 em 1996; 16 em 1997; 12 em 1998 e nenhum em 1999. Nota-se um acentuado 
Cidades Saudáveis no Brasil e os processos participativos: os casos de Jundiaí e Maceió

número de matérias no ano de 1995, durante a fase de implementação inicial de disseminação de idéias e de discussão das propostas, uma queda gradativa nos anos seguintes e uma queda vertiginosa no ano de 1999, fase em que as propostas deveriam estar sendo implementadas. Este foi o período em que o PJCS passou por uma fase de indefinições referentes à coordenação do Projeto e aos seus próprios objetivos.

As matérias publicadas nos jornais locais vão ser enfatizadas e mostradas em quadros no decorrer do texto. Verifica-se que conceitos como qualidade de vida, ação conjunta e, especialmente, a importância da participação da população no estabelecimento e na gerência do PJCS são muitas vezes mencionados nos

As estratégias para o combate dos principais problemas sociais, de acordo com o canadense Jack Lee, assessor da Prefeitura de Toronto e especialista em Cidade Saudável, pode demorar vários anos em alguns aspectos e, em outros, pode ser muito rápido. Para ele, a criação do projeto Cidade Saudável em Toronto foi muito importante: "a participação da imprensa é o suporte fundamental para a divulgação do projeto", concluiu. Lee mostrou-se impressionado com o entusiasmo e interesse dos diversos segmentos da sociedade que participaram do evento. Segundo ele, o projeto prevê a criação de uma série de comissões para manter uma ligação direta entre técnicos e a população (DSC do Canadá).

depoimentos dos segmentos envolvidos no Projeto, o poder público e as organizações sociais. O depoimento de um técnico da cidade de Toronto destaca o papel que se espera que a imprensa tenha na implementação dessa estratégia

(DSC do Canadá ${ }^{21}$ ).

\section{Histórico da implantação do PJCS}

Desde o final dos anos 1980, o Canadá mantém intercâmbio técnico com cidades brasileiras e de outros países no mundo. A cidade de São Paulo e a cidade canadense de Toronto - cidades irmãs - estabeleceram , nos anos de 1987 e 1988, vários contatos técnicos e implementaram juntas alguns trabalhos, especialmente no setor da saúde. O estreitamento de relações entre o Brasil e o Canadá vem se dando pelo contato de técnicos brasileiros da área de saúde com o Dr. John Andrew Lee (Jack Lee), assessor de saúde pública, com experiência em projetos Cidades Saudáveis na cidade de Toronto.

\footnotetext{
${ }^{21}$ Fonte: Jornais da cidade de Jundiaí. Ver referências $n^{\circ} 5$ e $n^{\circ} 7$.
} 
Jundiaí esteve entre as primeiras cidades brasileiras a conhecer a experiência canadense e avaliar a possibilidade de implantar o projeto na cidade. $\mathrm{O}$ contato com o Dr. Lee, de acordo com o coordenador do projeto na cidade até 1996, foi bastante casual. Estando em ano sabático, o Dr. Jack Lee, entusiasta do projeto Cidades Saudáveis, escolheu o Brasil para passar seis meses e quis aproveitar sua permanência no país para estreitar relações com alguns técnicos de cidades brasileiras, que poderiam ajudar na divulgação de propostas nessa perspectiva. Um desses técnicos, assessor da prefeitura de Jundiaí, na área de políticas públicas da Coordenadoria do Planejamento, foi um dos contactados, no ano de 1993, assim como outros técnicos da cidade de Diadema, Santos e São Vicente no Estado de São Paulo. Desde então, uma série de correspondências foram trocadas e algumas atividades começaram a ser desenvolvidas.

As justificativas para implantação de um projeto na perspectiva do ideário por Cidades Saudáveis puderam ser colhidas nas matérias dos jornais locais, divulgadas desde os primeiros contatos de técnicos da prefeitura de Jundiaí, com os técnicos da cidade de Toronto. Pode-se observar que essas justificativas estão vinculadas às mudanças de perfil demográfico e ao aumento da urbanização que vem
É grande a influência do processo de urbanização sobre o perfil de saúde. A urbanização combinada a pobreza, muitas vezes, estimula a inclusão de um acúmulo de problemas nas cidades contribuindo, até para o surgimento de doenças típicas dos países subdesenvolvidos.

A ONU divulgou recentemente um estudo alertando os especialistas das áreas de saúde e de controle social para o constante crescimento populacional.

Atualmente os grandes centros urbanos refletem as disparidades da sociedade, contrastando as cenas do mundo moderno ao retrato dramático dos altos índices de pobreza

Questões relacionadas a salários, educação e moradia em geral, influenciam a saúde da população, provocando desajustes sociais

A violência nos grandes centros urbanos pode ser associada à falta de condições socioeconômicas da população (DSC do Diagnóstico). se dando nos países, das quais decorre uma série de problemas sociais e de saúde (DSC do Diagnóstico) ${ }^{22}$.

Os primeiros passos para a implantação do projeto Cidade Saudável em Jundiaí ocorreram em 1994, através do assessor que manteve Lee em contato com os técnicos da Coordenadoria Municipal de Planejamento e da Secretaria Municipal de Saúde.

\footnotetext{
${ }^{22}$ Fonte: Jornais da cidade de Jundiái. Ver referências $n^{\circ} 1$ e $n^{\circ} 13$.
} 
Um dos técnicos da prefeitura daquele período explica como foram estas relações iniciais e a seleção da cidade:

"Nós ouvimos as colocações dele (Jack Lee) $e$ vimos que a nossa cidade realmente tinha condições muito favoráveis, tinha mecanismos operacionais que já eram praticados, no sentido de ser saudável ...” (EC3).

A primeira atividade mais estruturada do Projeto foi a realização de um seminário do qual participaram cerca de 40 pessoas, dentre os diversos segmentos da sociedade civil, funcionários públicos de vários setores do governo municipal, como a Coordenadoria do Planejamento, as Secretarias da Saúde, da Educação, da Administração, os quais reunidos compuseram uma imagem ideal da cidade de Jundiaí, que poderia ser concretizada a longo prazo, em 25 anos.

Este seminário, marco histórico na definição do PJCS, ocorreu em novembro de 1994, e recebeu ampla cobertura da imprensa local, constituindo-se em um primeiro fórum público de debates em que se explicitaram as concepções e princípios pautados na experiência do Canadá, adaptados à realidade local. O documento do seminário mostra isso:

"Uma cidade saudável é aquela em que os
dirigentes municipais enfatizam a saúde de
seus cidadãos dentro de uma ótica ampliada
de qualidade de vida, colocando em prática,
de modo contínuo, a melhoria de seu
ambiente físico e social e utilizando os
recursos de sua comunidade.
Deste modo, a questão da saúde passa a ser
considerada para muito além de "uma coisa
de médicos", assumindo o desenvolvimento
urbano um papel fundamental no padrão de
saúde das pessoas que habitam a
cidade”(PMJ 1994a).

Os discursos sínteses construídos permitem visualizar o comportamento dos jornais impressos a respeito do Projeto Jundiaí Cidade Saudável, evidenciando a disseminação de uma nova mentalidade. Pode-se verificar que a mídia local representou, de 1994 até o ano de 1998, fielmente as concepções e pressupostos de Cidade Saudável explicitados nos documentos divulgados pelos organismos 
internacionais, especialmente os estabelecidos em Toronto no Canadá, nos quais a Prefeitura de Jundiaí se espelha. Desta forma, tem destaque o conceito abrangente de saúde, entendido como qualidade de vida, a importância: da ação intersetorial e, sobretudo, a relevância da construção conjunta da cidade, com a participação de diferentes

Uma cidade saudável é aquela onde os moradores vivem e trabalham em condições que favoreçam sua saúde, melhorando seu meio ambiente - a qualidade da construção e localização das casas, transporte e trânsito, saúde, educação, produção e distribuição de alimentos, segurança pública, lazer, salubridade dos locais de trabalho, da água e do ar.

No conceito de cidade saudável a saúde deve deixar de ser vista como parte assistencial para ser uma forma de vida saudável; não é apenas uma questão de assistência médica é algo muito mais abrangente que precisa ser discutido com outros setores.

No conceito de cidade saudável, pessoas de diferentes setores partilharam de uma visão semelhante sobre o que é preciso para se ter uma cidade melhor.

A cidade sustentável engloba a questão ambiental, ecossistema, a organização da sociedade e o controle da população sobre as decisões que afetam a saúde e o bemestar . (DSC sobre o Conceito de Cidade Saudável)

setores sociais (DSC sobre o Conceito de Cidade Saudável) ${ }^{23}$

A idéia inicial foi construir um Projeto que criasse raízes na cidade, influenciando um processo de mudança organizacional e ideológica dentro e fora do governo. Essas mudanças deveriam levar os diversos setores da sociedade e do governo municipal a alterarem condutas e definir projetos de políticas públicas em relação a cidade em consonância com os pressupostos de uma cidade saudável:

"Enfim, uma cidade saudável é uma cidade
onde a máxima "prevenir é melhor do que
curar" vale na prática do governo e na
prática de seus cidadãos" (PMJ 1994a).

Os anos de 1994 e 1995 foram de grande mobilização em torno do PJCS. A realização do seminário conduzido pelo Dr. Jack Lee, em 1994, resultou em um documento síntese do Projeto, uma carta de princípios, proposta de prioridades para o desenvolvimento do Projeto e discussão de estratégias para alcance dos objetivos propostos.

\footnotetext{
${ }^{23}$ Fonte: Jornais da cidade de Jundiaí. Ver referências $n^{\circ} .25 ; n^{\circ} 8 ; n^{\circ} 6$ e $n^{\circ} 1$.
} 
Cidades Saudáveis no Brasil e os processos participativos: os casos de Jundiaí e Maceió

Os jornais locais publicados neste período enfatizaram os aspectos conceituais, operativos e organizacionais do PJCS. Os representantes do governo municipal estiveram empenhados em definir conjuntamente a implantação do PJCS, sendo que a partir dos projetos em andamento propunha-se desenhar uma proposta para a cidade. Nota-se, neste período, a importância política da Secretaria da Saúde nas definições e rumos do PJCS.

\begin{abstract}
A proposta de implantar o projeto Cidades Saudáveis foi reeditada pelo ex-titular da pasta do planejamento Marco Antônio Orlando e pela Secretária de Saúde, Ana Maria Müller, adequando o texto para Jundiaí.

A Prefeitura de Jundiaí deverá incorporar o projeto Cidades Saudáveis, de acordo com a Secretária da Saúde, em data ainda não definida. O trabalho ainda está na primeira fase, com estudos sobre sua viabilidade e o momento em que será implantado. A secretária explicou que o projeto representa hoje um novo conceito do processo de melhoria da qualidade de vida e que o nível de saúde é o resultado de uma interdependência. Jundiaí tem todas as possibilidades de fazer um projeto para a comunidade, explicou Ana. Para a Secretária a abertura da visão de saúde, vem ao encontro do trabalho desenvolvido pela Secretaria de Saúde.

O Coordenador Marco Antônio Orlando afirmou que aproximadamente 40 profissionais deverão participar do Workshop (sobre Cidade Saudável) e que as cidades de Curitiba, Belo Horizonte, Santos, Diadema, São Vicente e São Paulo também deverão apresentar propostas para a implantação do programa. Ana Müller, Secretária da Saúde, informou que os participantes do Workshop estarão reunidos nesta sexta-feira, no Paço Municipal. Para Marco Antônio Orlando, esta é uma grande oportunidade para se conhecer melhor o trabalho e a disposição do grupo.
\end{abstract}

Em forma de painel, os representantes expuseram no Workshop aspectos da administração pública, como planejamento, orçamento, serviços, saúde, educação, bem-estar social, habitação e polícia.

Hugo Silimbani Neto, coordenador do sistema de coleta Cata Treco, disse que a reunião definiu os comitês de trabalho e seus participantes.

O diretor da Semis, Jezimiel Antunes, afirmou que a Secretaria atende cerca de 250 crianças em situação de rua e que $15 \%$ da população jundiaiense tem renda familiar de um salário mínimo. A Prefeitura desenvolve programas de integração social e geradores de renda, que atendem também adultos desempregados.

O Secretário de Planejamento Sérgio Del Porto realizou uma explanação sobre o trabalho da Prefeitura. Segundo ele, o prefeito concorda que a estrutura está errada: estamos trabalhando visando à reestruturação da administração, afirmou. O secretário apresentou alguns dados: "conseguimos melhorar a qualidade de vida em Jundiaí. 97\% dos nossos domicílios têm água tratada de qualidade excelente e rede de esgoto. $100 \%$ têm coleta de lixo e $100 \%$ das nossas vias são iluminadas".

A Secretária da Saúde, Ana Müller e o presidente da Fumas (Fundação Municipal de Ação Social), Pe. Paulo André Labrosse, explicaram para a comissão canadense que acompanha o projeto a participação das secretarias em relação aos conselhos municipais: "o Conselho Municipal de Habitação permite uma participação maior da sociedade civil”, explica Pe. Paulo André.

José Roberto Parimoschi, diretor da Secretaria de Finanças, explicou a proveniência da verba da Prefeitura (DSC do Poder Público)

(DSC do Poder Público) ${ }^{24}$

Construir uma cidade saudável em 25 anos. Esta idéia de futuro permeou as discussões do Seminário Cidade Saudável. Em suma, 6 pontos foram abordados. Jundiaí Saudável poderia contar com uma administração pública eficiente e

\footnotetext{
${ }^{24}$ Fonte: Jornais da cidade de Jundiaí. Ver referências $\mathrm{n}^{\circ} 17 ; \mathrm{n}^{\circ} 7 ; \mathrm{n}^{\circ} 2$; $\mathrm{n}^{\circ} 6, \mathrm{n}^{\circ} 5, \mathrm{n}^{\circ} 29 ; \mathrm{n}^{\circ} 15 ; \mathrm{n}^{\circ} 24 ; \mathrm{n}^{\circ} 29 ; \mathrm{n}^{\circ} 30$.
} 
transparente, com continuidade administrativa; com uma sociedade civil organizada, participativa; com um desenvolvimento urbano que levasse em conta a preservação de áreas verdes, os recursos naturais e promovesse, ao mesmo tempo, o desenvolvimento da cidade; com um meio ambiente preservado, com um desenvolvimento econômico que garantisse pleno emprego e atividade econômica equilibrada, com serviços públicos de qualidade (PMJ 1994b).

As estratégias definidas de implantação do Projeto já apontavam as características que procuraria assumir:

- $\quad$ "Contribuir para a mudança de postura das pessoas e da coletividade quanto à promoção do bem estar físico, social e mental dos indivíduos e à preservação dos agravos à saúde coletiva;

- ser de caráter abrangente $e$ multidisciplinar;

- estimular e absorver a experiência da participação da população, contribuindo para o amplo controle social das políticas públicas para a cidade;

- $\quad$ referenciar suas ações sempre a uma visão de longo prazo, dando ao Projeto um caráter permanente;

- estimular o desenvolvimento de projetos sempre em parceria entre o governo (tanto o executivo quanto o legislativo) e os demais setores da sociedade local, buscando comprometer as entidades representativas $e$ lideranças reconhecidas na tarefa de obtenção de indicadores e resultados projetados;

- inovar positivamente no sentido da mudança cultural da sociedade local $e$ comportamental dos indivíduos que a integram, sempre em favor de uma atitude de compreensão do papel que cada indivíduo assume na condição de cidadão;

- considerar sempre o impacto causado pelas ações e projetos compreendidos, para além do espaço local ( a cidade) e do tempo atual (hoje). Compreender dinamicamente esses parâmetros, segundo a geografia, a cultura, a 
história, a economia e a política em âmbito local, regional e supraregional" (PMJ s/d).

Os documentos iniciais delineavam operacionalmente o PJCS como um articulador das políticas públicas locais. Estaria, nesse sentido, constituído como uma agência de desenvolvimento de políticas públicas, que deveria agir tanto internamente ao governo, como em setores externos a ele, tendo o papel de facilitar a interlocução e potencializar esforços visando à concretização dos objetivos assumidos pelo Projeto.

Esses documentos também definiam o papel do PJCS, como uma iniciativa que envolvia o governo local articulado com outros segmentos da sociedade civil, como associações de moradores e de categorias profissionais, sindicatos, organizações não governamentais, entre outros, que conjuntamente trabalhassem as iniciativas originadas em locais da cidade, como bairros, ruas, fábricas, etc., visando desenvolver políticas públicas saudáveis.

\section{"Nós podíamos desenvolver as políticas públicas saudáveis, era só orientar melhor as ações que estavam ocorrendo no poder público em conjunto com a sociedade "(EC3).}

Desta forma, foi estabelecido um arranjo organizacional próprio do Projeto, separado daquele do governo municipal. Deu-se o estabelecimento de um organograma com uma estrutura da qual faria parte a Coordenadoria Municipal do Planejamento para permitir a operacionalização rápida do Projeto e atingir uma legitimidade política e programática independente.

“Jundiaí começou chamando de Projeto e
continua chamando de Projeto, porque a
gente tem a convicção que ele não é um
programa. Ele não é um programa onde eu
aplico soluções imediatistas e no dia seguinte
nós temos todos os problemas resolvidos. É
um projeto porque ele fala de longo prazo
daqui a vinte anos, pros nossos filhos, nossos
netos. Ele tem que ser praticado de maneira
permanente" (EC3).

De forma sucinta, o organograma inicialmente proposto definiu a formação do Conselho da Cidade Saudável composto de todas as entidades e órgãos de 
governo interessados e previamente cadastrados, que tinha como função decidir as estratégias de longo prazo do Projeto, e a formação de Comitês, grupos de trabalho, com seus respectivos projetos, que se articulariam entre si.

Nos meses seguintes, houve a definição e detalhamento de objetivos e estratégias de curtíssimo e curto prazos para legitimar rapidamente os princípios do PJCS e viabilizar os objetivos de médio e longo prazos, a elaboração de cronogramas e a formação de comitês que viabilizariam as prioridades estabelecidas. Esta organização baseou-se nos pressupostos do Planejamento Estratégico Situacional, destacando aqueles que ressaltam a importância de envolvimento de amplos setores da sociedade civil e de órgãos governamentais na definição das estratégias. Os quatro comitês definidos : de Pesquisa, de Negociação, de Planejamento e de Comunicação procuraram ajustar-se às estratégias básicas e desenvolver o projeto utilizando-se os recursos locais.

Os jornais da cidade divulgaram dezenas de matérias abordando as características que deveriam assumir o Projeto, seus conceitos e objetivos a serem alcançados. O que mais se evidencia é a disposição de se realizar uma ação conjunta entre diferentes, mais especificamente entre governo e sociedade. Esta parceria representa, em suma, a sustentação do Projeto na cidade (DSC das Características. do PJCS $)^{25}$

O projeto Jundiaí Cidade Saudável reúne um conjunto de ações e atividades que procura ajudar na melhoria dos níveis de saúde da população, com programas que envolvam tanto a comunidade, como o Executivo e o Legislativo.

Queremos que as próprias pessoas possam nos ajudar. É importante colocar o governo no seu papel, mas não se pode deixar que toda a responsabilidade fique só com ele.

O projeto não é governamental, a busca é pela construção de uma organização na cidade para a prática na obtenção da saúde.

O objetivo é integrar todas as secretarias municipais, sindicatos, entidades de classe e a população para discutir e resolver problemas sociais em conjunto e melhorar a qualidade de vida das pessoas.

A população não deve esperar que apenas as autoridades municipais realizem melhorias nos bairros da cidade. O processo deve ser inverso, os moradores que conhecem melhor do que ninguém as carências e dificuldades de seu bairro é que têm de batalhar para isso.

O primeiro passo para a junção dos trabalhos é o interesse das diversas comunidades em participar.

Esse projeto só funcionará se crescer em função da participação da comunidade e da vontade do setor público (DSC das Características do PJCS)

${ }^{25}$ Fonte: Jornais da cidade de Jundiaí. Ver referências $n^{\circ} 21 ; n^{\circ} 16 ; n^{\circ} 1 ; n^{\circ} 6 ; n^{\circ} 14, n^{\circ} 19, n^{\circ} 25$. 
Cidades Saudáveis no Brasil e os processos participativos: os casos de Jundiaí e Maceió

A ênfase na dimensão

participativa do Projeto, um de seus eixos norteadores, se explicita também por meio do chamado à sociedade por meio da imprensa, feito pelo poder público. Procura-se incorporar a comunidade nos projetos decorrentes do PJCS, ampliando assim, as diversas formas de inserção da sociedade na gestão, cabendo a ela um papel fundamental no desenvolvimento da cidade (DSC
Para se chegar a uma cidade e comunidades saudáveis, existe um longo processo, que tem como ponto de partida a questão cultural e o envolvimento da comunidade.

Com efeito, é importante o papel do cidadão para se construir uma Cidade Saudável, bem como o fortalecimento do controle social e parceria, ampliação dos projetos específicos e o aumento e diversificação da participação nos bairros.

A participação da sociedade na resolução dos problemas a ela relacionados é muito importante.

Os projetos são feitos e dependem da população para dar certo.

A Prefeitura de Jundiaí espera que a comunidade participe, cada vez mais assumindo um importante papel no desenvolvimento permanente da cidade (DSC sobre a participação das organizações da sociedade civil)

sobre a participação das organizações da sociedade civil) ${ }^{26}$.

\section{Estratégias de disseminação da idéia}

\section{VILA ARENS}

A Vila Arens foi o bairro escolhido para dar início ao PJCS, dadas suas características urbanas e populacionais e o envolvimento de suas lideranças na organização. Procurou-se também compatibilizar três projetos já existentes como uma ação conjunta no bairro, enfatizando os princípios de uma cidade saudável (figura 7), o Projeto Conheça seu Bairro - da Coordenadoria de Planejamento, que teve como ponto de partida a divisão da cidade em bairros e regiões de planejamento, a realização de estudos para obtenção de informações e, posteriormente, a construção de indicadores de qualidade de vida; o Projeto Cata-Treco, da Secretaria da Saúde, de coleta seletiva de lixo, e o Projeto Policiamento de Bairro, da Polícia Militar, que visava desenvolver a visão de policiamento comunitário, com a inserção do policial na vida da população (PMJ 1995).

\footnotetext{
${ }^{26}$ Fonte: Jornais da cidade de Jundiaí. Ver referências n ${ }^{\circ} 54$ e $n^{\circ} 5$.
} 

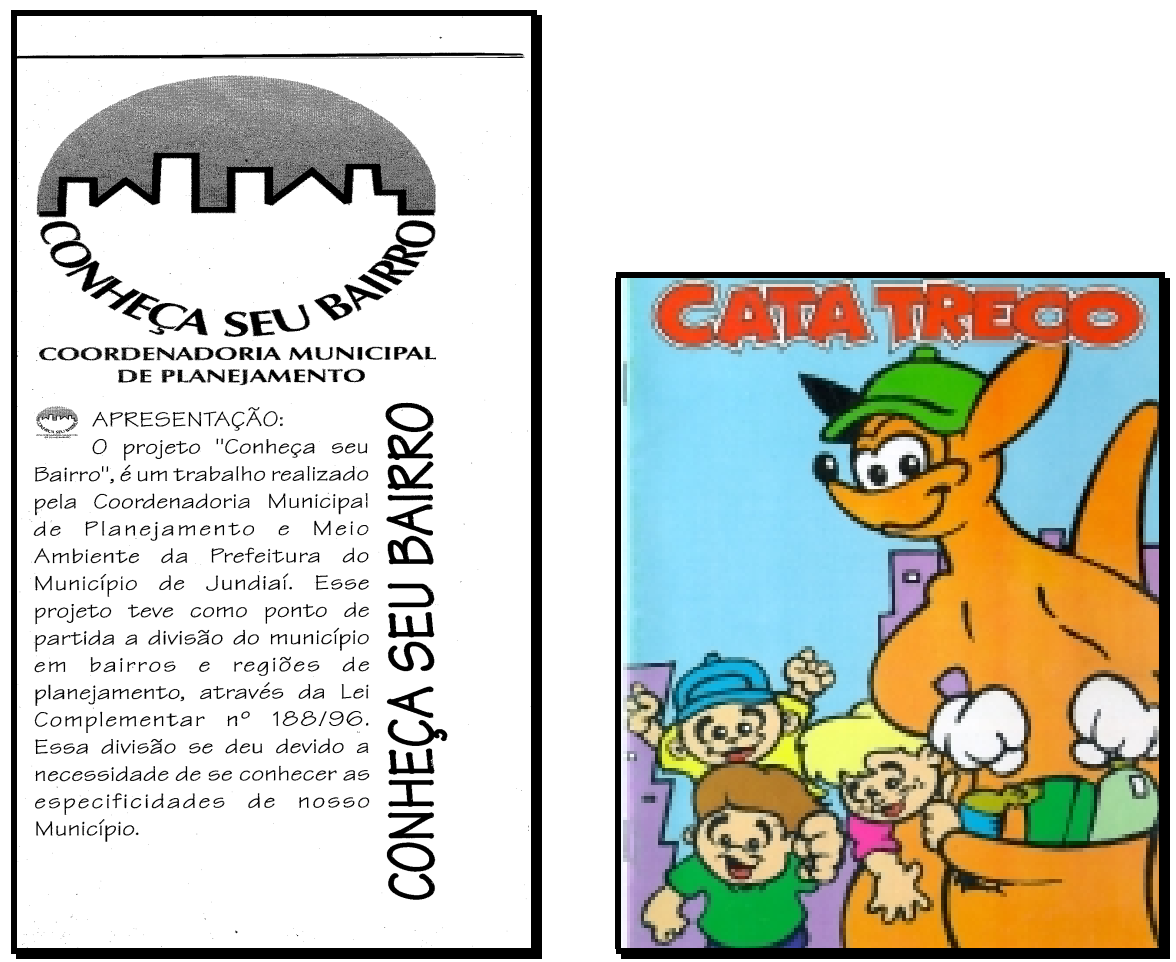

Figura 7 - Material de divulgação de projetos da Prefeitura Municipal de Jundiaí.

O primeiro evento promovido pelo Projeto com apoio do GAC- Grupo de Apoio à Comunidade da Vila Arens, formado por várias instituições do bairro, entre elas, escolas, Faculdade de Medicina, Colégio Divino Salvador, APAE, comércio, igreja, polícia comunitária, clubes, profissionais liberais, ocorreu no dia 29 de junho de 1995. Teve por objetivo divulgar o ideário do PJCS, iniciar ações localizadas que pudessem fortalecer o Projeto na cidade e ser um ponto de partida para a realização de projetos em outras comunidades. O encontro ultrapassou a expectativa dos organizadores e o local escolhido para a reunião, o Salão Paroquial da Igreja Nossa Senhora da Conceição, foi pequeno para abrigar centenas de pessoas, perto de 400 , que ouviram da coordenação do PJCS a exposição das linhas básicas do Projeto e realizaram em grupo, trabalhos de levantamento de problemas e propostas de encaminhamento de ações integradas entre a comunidade e o governo visando à melhoria da qualidade de vida local. 


\begin{abstract}
Embora, ainda hoje, o
bairro faça-se representar no

Comitê Cidade Saudável através de representante do GAC, e promova atividades na perspectiva da construção do Bairro Saudável como pode ser observado no material distribuído no bairro em abril de 1999 sua inserção no PJCS é frágil (figura 8). As ações desenvolvidas não são previamente organizadas ou discutidas e perdeu-
\end{abstract} se a perspectiva de que essa

\section{INFORMATIVO GAC}

Vila Arens bairro saudável

Voce sahia que:

- O Brasil produx $90 \mathrm{mil}$ son.jía de lixe?

- Oue 50 son. sino restos do comida?

+ Woob sabe aonde vai seu liso diária?

- Voce ed daqueles que joga lixo pelas ruas ou nos bueiros?

- Todo o lisa que nós producimas a

depositade nios lixōes. Vocể postaria que ele

estivease prósims a sua casa ou trabalhe?

Enclo vumos produsir menos lise, $\mathrm{e}$ reoiclar mais, promovendo a coleta seletiva.

GAC - Grupo de Apoío a Comunidade de Vila Aremo

Vace conhece?

Noce participa?

Vocé mera su trabalha no hairro?

Você = ajada on só critica?

For que voce também nalo vem ajudar?

Mostere sua eidadania.

Figura 8 - Material de divulgação do GAC

experiência pudesse contribuir para o fortalecimento de outras iniciativas na cidade.

No grupo focal com o Comitê Cidade Saudável houve referência ao Projeto na Vila Arens:

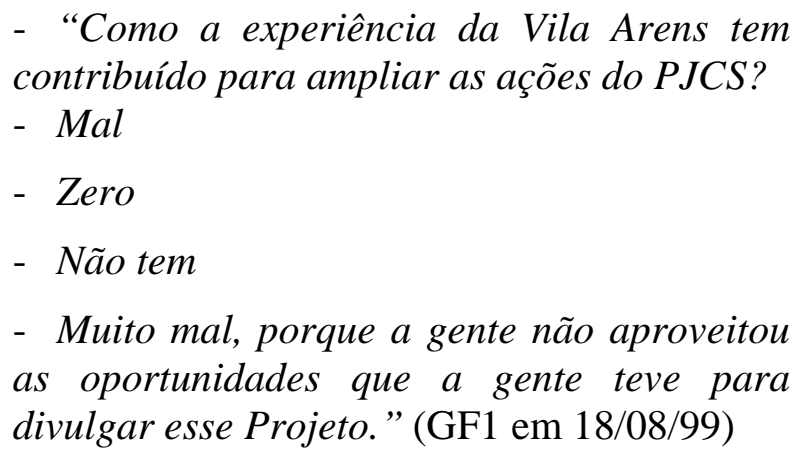

\title{
OS CONCURSOS ESCOLARES
}

Pode-se afirmar que os anos de 1995 e 1996 foram os de maior envolvimento da prefeitura e da sociedade civil e, portanto, os que mais repercutiram os pressupostos do PJCS na cidade. O evento mais significativo do ponto de vista de disseminação dos pressupostos do Projeto entre a população da cidade foi a realização do concursos entre os escolares de $1^{\circ}$ e $2^{\circ}$ graus, em setembro de 1995 , que envolveu 150 escolas e cerca de 60 mil alunos (figura 9). O segundo concurso, realizado no ano seguinte, em novembro de 1996, chegou a atingir 90 mil alunos (figura 10). Ambos tinham por objetivo disseminar a idéia de uma cidade saudável. Diz o ex- coordenador do Projeto: 
“... nós íamos construir um referencial, era uma pressão muito grande, o grupo queria concretizar, porque isso é uma necessidade, você precisa mostrar para as pessoas, com objetividade, alguns progressos para validar o ideário do projeto...” (EC1).
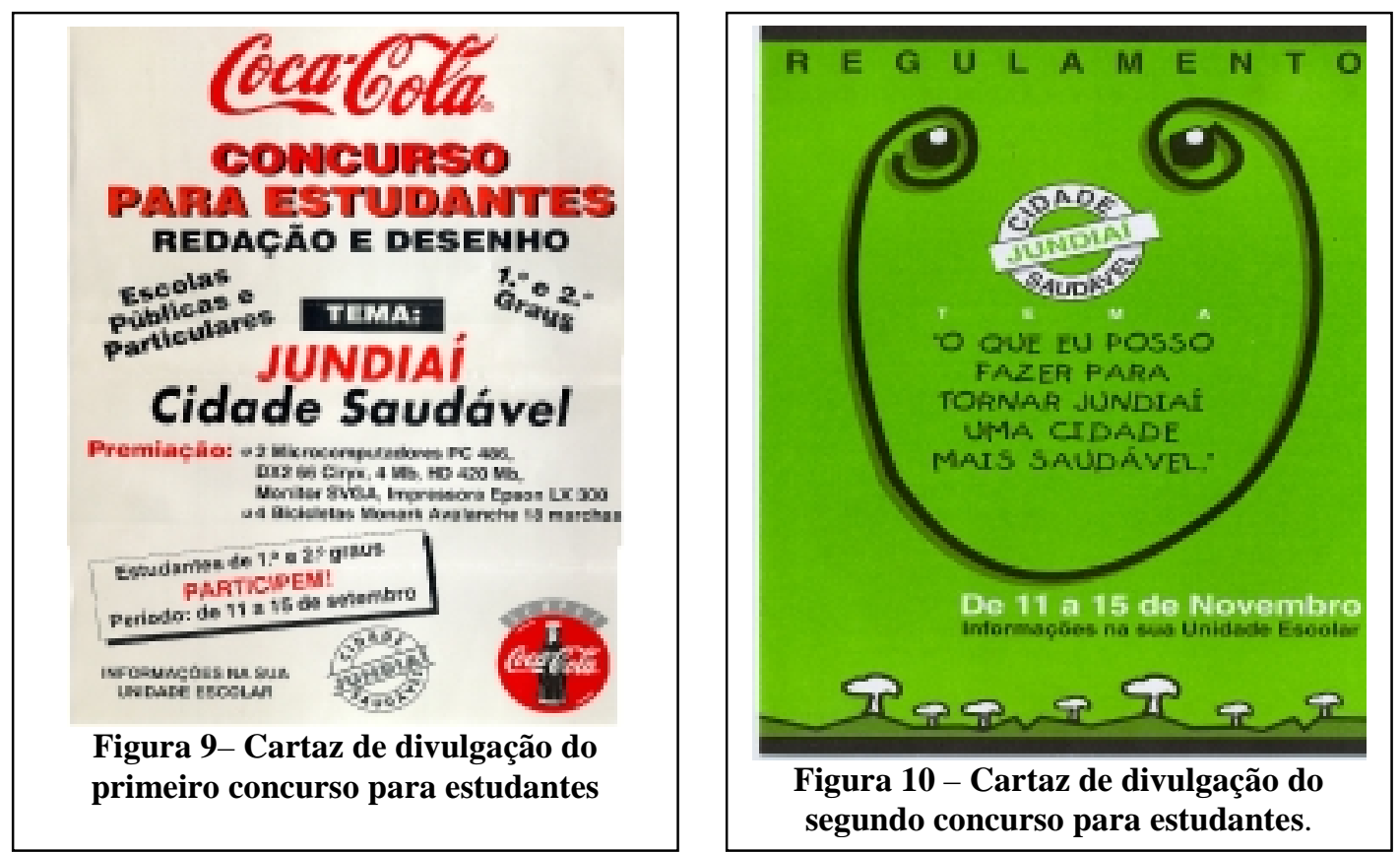

Esta iniciativa acabou mobilizando a sociedade de Jundiaí como um todo e deu ao Projeto uma projeção bastante importante. Sob patrocínio da Coca-Cola que investiu 9 mil reais, o $1^{\circ}$ concurso para estudantes teve como tema Jundiaí Cidade Saudável, em que os alunos apresentaram um trabalho dissertativo e um ilustrado. Contou com a participação de 60 mil alunos de 103 estabelecimentos de ensino. O concurso premiou desenhos e redações elaborados pelos alunos que escreveram e desenharam sobre os problemas e pontos positivos da cidade de Jundiaí. A finalidade do concurso, realizado no ano de 1995, foi de incentivar os estudantes a discutir com a comunidade o perfil de uma Jundiaí Saudável.

O $2^{\circ}$ concurso realizado no ano de 1996, sob patrocínio da Coca-Cola e da Spal, objetivou apontar as ações que poderiam ser desenvolvidas para a construção de uma Jundiaí mais saudável. Foi voltado para estudantes de $1^{\circ}$ grau, que deveriam apresentar um trabalho ilustrativo, e para alunos de $2^{\circ}$ grau, que apresentaram slogans. Foram incluídas também as classes especiais e escolas de deficientes 
De acordo com uma das coordenadoras dos concursos, a fase de divulgação era precedida de atividades que visavam dar visibilidade à iniciativa. De fato, a imprensa local deu uma ampla cobertura aos concursos, tendo sido registrados só no ano de 1995, 13 artigos nos jornais locais sobre o tema, que noticiaram desde o lançamento do $1^{\circ}$ concurso, sua implementação até a premiação. Uma etapa importante prevista foi a sensibilização das escolas envolvidas, por meio da sensibilização dos diretores e dos educadores, que deveriam multiplicar a idéia de uma Jundiaí Saudável em suas disciplinas, enfocando a complexidade dos fatores que poderiam contribuir para a construção de uma cidade mais saudável. Cerca de 3000 professores foram envolvidos nessas atividades.

O então prefeito da cidade André Benassi lançou o $1^{\circ}$ concurso em 24 de agosto de 1995, ressaltando a importância da iniciativa do projeto Jundiaí Cidade Saudável. A imprensa local destacou: “Benassi lança concurso que vai movimentar escolas”.

A escolha dos melhores trabalhos foi distinta nos dois concursos. No primeiro, houve uma seleção inicial realizada nas próprias unidades escolares, quando foram classificados 600 trabalhos. As delegacias de ensino escolheram 50 trabalhos que foram submetidos a uma "comissão de especialistas", formada por educadores, artistas plásticos, profissionais de propaganda e marketing e jornalistas, que elegeu os 6 premiados que receberam microcomputadores e bicicletas. Noticiou o Jornal de Jundiaí em 12 de outubro de 1995:

“Os alunos abordaram o seu bairro ou a
cidade como um todo. Foi muito questionada
a questão da despoluição do rio Jundiaí, a
preocupação com o meio ambiente, educação,
saúde, o resgate do espaço cultural do
Politheama e as áreas de lazer, avaliou
Alexandra Normanton, coordenadora do
concurso Jundiaí Cidade Saudável" (Jornal
de Jundiaí 12/10/95).

Para os alunos, uma Cidade Saudável tem estreita relação com as questões ambientais conforme mostra o trabalho vencedor na categoria de Ilustração (figura 11). 
A premiação, bem como a exposição dos 50 melhores trabalhos foram realizadas em outubro de 1994, no Paineiras Center.

O $2^{\circ}$ concurso, de 1996, cujo tema: Qual é o papel do cidadão na construção de uma Cidade Saudável - ampliou o número de participantes para 90 mil e alterou alguns pontos. Os professores também foram premiados e os vencedores foram escolhidos, após seleção nas escolas e delegacias de ensino, e posteriormente, por meio de votação popular. Nesta iniciativa, os

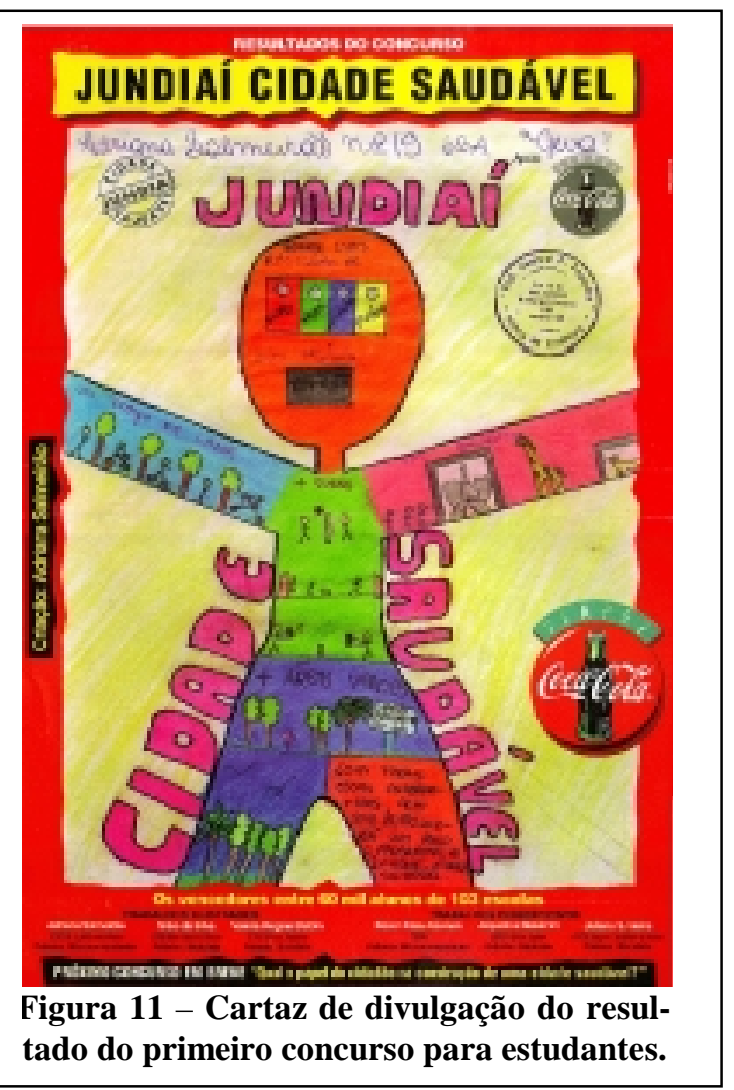
trabalhos selecionados foram expostos em um Shopping da cidade por 8 dias, e os 6 melhores trabalhos foram escolhidos pela população da cidade, cerca de 2800 votantes. Diferente do $1^{\circ}$ concurso em que o prefeito da cidade acompanhou desde o lançamento até a premiação, este concurso não contou com autoridades do governo municipal e não teve a mesma divulgação do anterior. No entanto, como noticiou o Jornal da Cidade em 17/12/96 o coordenador do PJCS avaliou que os objetivos estabelecidos foram alcançados:

"Esse concurso escolar atingiu todo o
objetivo, que era de discutir com a
comunidade o papel que o cidadão
desempenha na formação de uma cidade com
melhor qualidade de vida" (Jornal da Cidade
17/12/96).

Essas iniciativas foram muito efetivas e de alto impacto no entender do excoordenador do PJCS. Os concursos, segundo ele, colocaram a agenda do Projeto Jundiaí Cidade Saudável nas escolas, por meio da discussão do meio ambiente, sobre o comportamento das pessoas em relação ao meio ambiente, a influência de políticas na qualidade de vida. No entanto, muito embora esse trabalho tenha mobilizado todas 
as escolas de Jundiaí, e a Secretaria de Educação entendesse a visibilidade política dos concursos, dando todo o apoio necessário para sua consecução, não houve envolvimento efetivo do setor da educação no Projeto como um todo:

"A secretaria da Educação nunca veio, ela
colaborou no momento de organização,
porque acabou virando uma obrigação lá
dentro do governo, mas ela nunca aproveitou
esse material, que é riquíssimo ..." (EC1).

Neste mesmo período no ano de 1996, buscou-se também a integração dos Conselhos Municipais, tendo sido criado o Fórum dos Conselhos Municipais sob a coordenação do PJCS. Nessa direção foi realizado o seminário Participação $e$ Cidadania, em 26 de abril de 1996, que buscou ampliar os debates em torno dos temas da participação e dos direitos de cidadania.

\section{Sustentabilidade}

A sustentabilidade e a continuidade do Projeto começaram a ser pauta de discussão no ano de 1996. A sucessão municipal e a renovação da Câmara de Vereadores faziam parte da agenda do PJCS. Os 4 candidatos foram convidados a participar de um ciclo de debates promovido pelo Projeto, em que apresentaram, primeiramente, os princípios norteadores do PJCS e seu estágio de desenvolvimento e, em seguida, promoveram espaços de discussão para que os candidatos expusessem seus planos para favorecer um desenvolvimento saudável e sustentável para a cidade, através de ações intersetoriais e com a participação dos cidadãos. $\mathrm{O}$ programa do candidato do PSDB, que acabou vitorioso no pleito de 1996, incluiu vários aspectos que já vinham sendo desenvolvidos pelo Projeto desde o ano de 1994.

A continuidade administrativa, no entanto, não assegurou que o PJCS se mantivesse com a força que vinha tendo nos últimos dois anos do governo anterior. Inúmeras mudanças começaram a se dar a partir do ano de 1997. O Projeto sai da Coordenadoria do Planejamento e fica localizado no gabinete do prefeito. Embora este fato possa sugerir ganho de força política para o PJCS nesse momento, não foi o que ocorreu. De acordo com depoimentos de técnicos, o Projeto acabou assumindo um caráter mais administrativo. A nova coordenação não conseguiu manter os canais de interlocução que estavam se estabelecendo dentro do próprio governo e tornou-se 
também menos articuladora dos fóruns de participação das diversas instituições sociais da cidade.

Nem mesmo a retomada dos contatos com o Canadá, ocorrido em 1997, garantiu que o Projeto fosse priorizado e seus objetivos rediscutidos. Em meados daquele ano, ocorreu uma série de reuniões entre a prefeitura da cidade de Toronto, a Universidade de Toronto e técnicos de Jundiaí, com o objetivo de inserir a cidade entre os projetos pilotos que se desenvolveriam no Brasil, em cooperação técnica, que incluiriam a Fundação Getúlio Vargas (FGV) e outras Organizações Não Governamentais brasileiras. Dos 14 municípios inicialmente escolhidos para firmar um acordo de cooperação, Jundiaí e Fortaleza foram selecionados para o desenvolvimento de projetos considerados pilotos na criação de uma rede de Cidades Saudáveis no Brasil. Técnicos das duas cidades e da FGV, incluindo o coordenador do PJCS, visitaram o Canadá para a realização de um anteprojeto que seria posteriormente submetido à CIDA - Canadian International Development Agency. Em relatório de viagem, o então coordenador do PJCS concluiu:

"A CIDA possui um fundo denominado de "Transferência de Tecnologia”, que dispõe de CAN\$ 900.000 (correspondentes a US\$600.000) para financiar projetos de assistência técnica no Brasil. A Universidade de Toronto, através do Centro de Urbanismo e Estudos da Comunidade, está tentando desenvolver e habilitar o Projeto de Redes de Cidades Saudáveis no Brasil, cujos municípios pilotos são Jundiaí e Fortaleza ... Ações conjuntas entre os dois municípios deverão ser desenvolvidas ..." (PMJ 1997).

Entretanto, os jornais locais deram ênfase à tentativa de acordo, em que o representante da CIDA da cidade de Toronto afirmava que não haveria repasse de recursos. O representante da CIDA deixou claro o significado da transferência de tecnologia no acordo com as cidades brasileiras, em que se previa apenas a troca de informações e auxílio técnico (DSC do Canadá) ${ }^{27}$.

\footnotetext{
${ }^{27}$ Fonte: Jornais da cidade de Jundiaí. Ver referências n²6, n²8 e n²9.
} 
Embora o PJCS tenha definido, em um documento, suas intenções e propostas de atuação, que se dariam por meio do estabelecimento de um convênio entre as partes, este acabou não ocorrendo. Mudanças de interesses por parte do governo canadense, que alteraram significativamente sua estrutura de governo e a equipe técnica da prefeitura de Toronto no ano de 1998, bem como discordância em relação aos encaminhamentos dos projetos, encerraram os contatos das cidades de Jundiaí e Fortaleza com o Canadá. De acordo com técnicos de Jundiaí, as cidades estavam firmemente empenhadas em estabelecer um convênio, contudo, não se chegou a um acordo em relação ao modelo de parceria que deveria ser estabelecido. Os projetos considerados prioritários pelas cidades brasileiras não eram aqueles de interesse do governo do Canadá, por outro lado, os projetos apresentados pelo Canadá não se adequavam às necessidade das cidades.

Esses fatos não foram divulgados pela imprensa local. Os embates e conflitos que surgiram no decorrer da implantação do acordo, bem como os motivos que cercaram a descontinuidade de algumas ações e propostas, não foram registrados. A imprensa de Jundiaí não acompanhou a evolução das discussões. $\mathrm{O}$ relacionamento técnico, que até então vinha se dando com uma certa freqüência entre a cidade de Jundiaí com e o Canadá, rompeu-se abruptamente naquele período, não tendo sido recuperado

$\mathrm{Na}$ verdade seremos quatro pessoas: um representante da federação canadense de municípios, Brock Carlton, um professor da Universidade de Montreal, Mr. Latouz; Cláudia Marcondes da Universidade de Toronto e eu, que represento a prefeitura de Toronto. Teremos a missão de analisar e verificar a adaptação dessas cidades ao projeto. A partir dessa análise, o governo canadense estudará a possibilidade de formar vínculos com o Brasil. Isto é, o governo canadense verá se vale a pena investir nessas cidades de forma efetiva.

Os canadenses prometeram continuar o relacionamento com Jundiaí, "para melhorar mutuamente". Estamos avaliando a possibilidade de Jundiaí obter ajuda do Canadá para a realização de projetos", explica Brock Carlton, representante da Federação dos Municípios do Canadá. Carlton descartou a liberação de dinheiro por parte do governo canadense: não haverá investimento financeiro, apenas troca de informações e auxílio técnico do governo do Canadá para a cidade de Jundiâ̂’. (DSC do Canadá)

até os dias de hoje. Não se pode afirmar categoricamente que este afastamento tenha sido um dos principais fatores de desaquecimento do Projeto na cidade, contudo, há de se considerar que este fato contribuiu para que o PJCS se tornasse mais frágil do ponto de vista técnico e político. 
O ano de 1997 encerrou-se com a realização do $1^{\circ}$ Encontro do Projeto Jundiaí Cidade Saudável (figura 12), que reuniu diversas experiências, entre elas a de Campinas, Santos e Vargem Grande Paulista, todas do Estado de São Paulo.

No ano seguinte, 1998, o PJCS perde sua visibilidade e realiza poucas atividades na cidade, e, no ano de 1999, o Projeto volta a se localizar na Coordenadoria do Planejamento e busca, nesse momento enfraquecido, retomar as discussões e propostas de trabalho. A principal reestruturação e redefinição de caminhos deu-se na reunião do Comitê Cidade Saudável em agosto de 1999, em que foi estabelecida uma nova coordenação do Projeto, a $4^{\text {a }}$ desde a definição do PJCS, estando agora, pela primeira vez, a cargo de um membro de uma organização da sociedade civil, justamente na fase em que o Projeto está mais enfraquecido.

Cabe ressaltar que o PJCS possui, desde 1995, um recurso orçamentário próprio que a cada ano diminui. Quando o projeto foi criado, havia uma previsão de recurso financeiro de $\mathrm{R} \$ 20$ mil, por ano, e hoje está em torno de $\mathrm{R} \$ 4$ mil. O recurso está vinculado à Secretaria do Planejamento e nunca foi gasto.

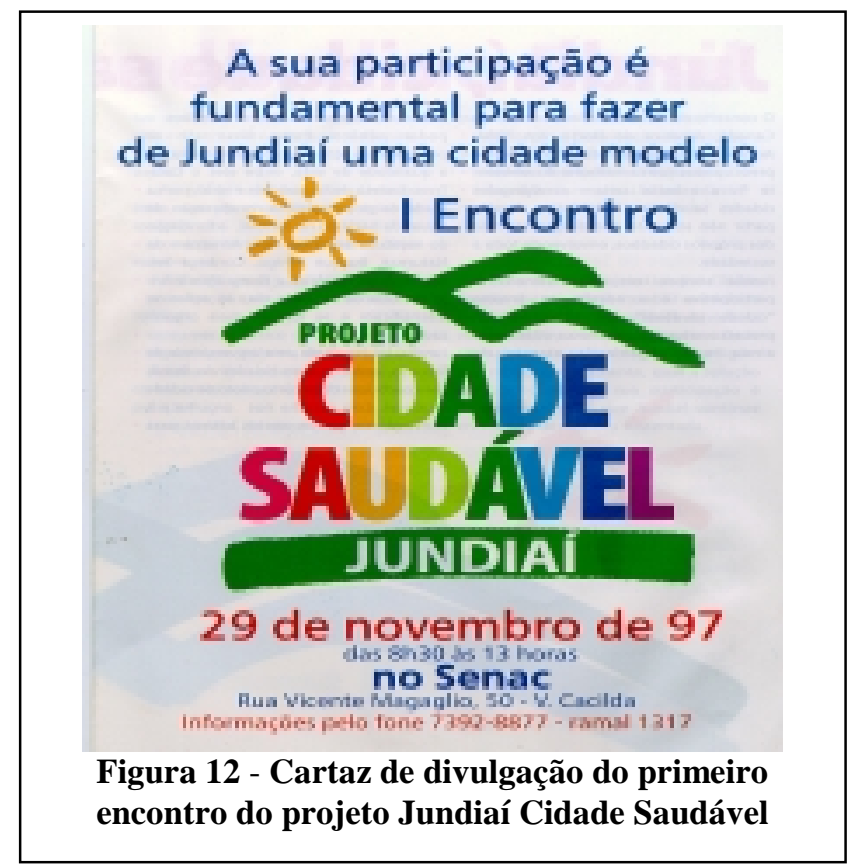

\section{Intersetorialidade}

A busca de uma solução integrada dos problemas de uma cidade é um dos pressupostos que sustentam a proposta por Cidades Saudáveis. A intersetorialidade, como salienta JUNQUEIRA (1998), permite informar um novo formato organizacional das administrações públicas, além de possibilitar a otimização de recursos disponíveis, tornando a gestão municipal mais aderente às necessidades dos cidadãos. 
Uma vez que se defende que a saúde é mais do que simplesmente a ausência de enfermidades, defende-se também que uma série de fatores que a determinam situam-se fora do setor de atenção à saúde. A cooperação entre os diferentes setores da sociedade é solicitada para condicionar positivamente os determinantes do processo de produzir saúde, que estão relacionados às condições socioeconômicas e políticas. Os conceitos relacionados a determinação social da saúde e à intersetorialidade do Projeto Jundiaí Cidade Saudável puderam ser extraídos dos jornais locais (DSC das Características do PJCS) ${ }^{28}$.

Pode-se observar que na prática, entretanto, os alcances da intersetorialidade através, do PJCS foram bastante restritos, apesar das iniciativas que buscavam o desenvolvimento de políticas públicas integradas, que já existiam na cidade, e que o Projeto incorporou. Projetos que se desenvolvem, ainda hoje, na perspectiva de construir uma cidade com qualidade de vida Jundiaí vem desenvolvendo o projeto Cidade Saudável, numa parceria entre a Prefeitura Municipal e os bairros interessados. Visa ao alcance dos padrões sanitários mínimos da população, ou seja, a saúde obtida através dos trabalhos com nível de vida e de trabalho, renda, cultura, política e administração pública.

A atenção especial deve ser com distribuição de renda, geração de empregos, industrialização, condições ambientais, poluição, fontes poluidoras, enfim, as condições de vida de cada cidadão.

As pessoas têm com a saúde uma relação de propriedade muito intensa. No caso específico da área de saúde, a proposta é encampar não só questões de assistência médica, mas também de moradia, saneamento e lazer.

Entre os principais pontos discutidos pelo CS estão as necessidades consideradas básicas pela população: alimento, água, moradia, salário, segurança e trabalho.

Começamos a pensar Jundiaí saudável por inteiro, como a queremos no futuro.

É um trabalho que exige longo prazo, muita discussão, afinação e ação (DSC das Características do PJCS).

saudável, como o Cata-Treco,

Bosque Amigo, Armazém da Natureza, Policiamento Comunitário, e outros, que tinham possibilidades de se articularem no âmbito de uma política social integrada, deram-se independentemente do PJCS.

Ficam claros os esforços de buscar integração entre os diversos setores de governo, especialmente nos primeiros anos de desenvolvimento do Projeto, bem como superar o caráter de políticas fragmentadas existentes na administração pública. Esses esforços nem sempre foram bem sucedidos. Não se chegou a criar novos desenhos de implementação de políticas para a cidade por meio do PJCS, nem tampouco criou-se um sistema de monitoramento das ações que foram incorporadas.

\footnotetext{
${ }^{28}$ Fonte: Jornais da cidade de Jundiaí. Ver referências $n^{\circ} 16 ; n^{\circ} 6$ e nº 14 .
} 
Cidades Saudáveis no Brasil e os processos participativos: os casos de Jundiaí e Maceió

O discurso da intersetorialidade perdeu força com a mudança de governo no ano de 1996, justamente quando parte do secretariado do governo mais envolvida com o Projeto deixou a administração.

\section{Dinâmica de interação e participação no PJCS: a relação entre poder público e sociedade civil}

Desde seu início, os documentos referentes ao estabelecimento do PJCS dá importância à participação da sociedade civil e dos setores do governo municipal, reafirmando que sejam construídos e fortalecidos os canais de participação, entendidos como canais de expressão na construção da cidadania.

Os documentos iniciais do PJCS delineiam que deveria haver flexibilidade em relação aos participantes. As pessoas interessadas em participar no desenvolvimento do Projeto deveriam se sentir estimuladas e foram consideradas importantes agentes de disseminação da proposta. No entanto, sugere-se que sempre que possível, os participantes sejam engajados em movimentos, entidades associações ou outras formas de representação social e política.

Esta abertura resultou no envolvimento dos mais diversos setores da sociedade civil de Jundiaí, muitos de forma esporádica. Parece um tanto complexo definir com exatidão quem são os segmentos da sociedade civil e do poder público que fizeram parte do PJCS, e que ainda hoje estão participando de suas atividades.

As entrevistas com informantes-chave permitiram delinear o Mapa de Integração e Participação do PJCS, que foi sendo alterado no decorrer desses cinco anos de existência do Projeto. A Secretaria da Saúde e a Coordenadoria do Planejamento, hoje Secretaria de Planejamento e Meio Ambiente, foram os órgãos públicos que inicialmente fomentaram a participação tanto de organizações da sociedade civil, quanto de setores do governo municipal. Entretanto, com as mudanças ocorridas tanto na condução política, quanto no corpo técnico do governo municipal a partir das eleições de 1996, a Secretaria da Saúde deixou de ter atuação no Projeto e a Secretaria do Planejamento assumiu a sua articulação dentro do governo municipal. Nos anos em que o PJCS esteve vinculado ao gabinete do prefeito, embora todas as secretarias tivessem participado de reuniões, há uma crítica bastante contundente por parte de técnicos a este período. Os seus representantes eram indicados formalmente pelos respectivos setores, mas muitos deles sequer 
entendiam porque participavam. O retorno do Projeto à Secretaria de Planejamento acabou com essa vinculação e o Comitê Cidade Saudável, muito enfraquecido, voltou a se reunir com entidades e secretarias interessadas em contribuir no desenvolvimento do PJCS.

Inúmeros institutos e organizações da sociedade civil participaram de atividades relacionadas ao PJCS. São citados: o Instituto dos Arquitetos do Brasil (IAB), a Associação dos Bacharéis de Economia, Ciências Contábeis e Administração (ABECA), a Polícia Militar, o Grupo de Apoio à comunidade da Vila Arens (GAC), a Associação Terapêutica de Estimulação Auditiva e Linguagem, (ATEAL), a Comissão das Áreas Ribeirinhas do Rio Jundiaí (COMARJU), a Associação dos Engenheiros, a Ação Pró Jundiaí (APJ), o Instituto Serra do Japi, o Conselho Municipal de Saúde, A FUMASFundação Municipal de Ação Social, a CETESB, a Escola de Línguas Wizzard.

As motivações para participação no PJCS parecem ser muito semelhantes: "um projeto que visa a qualidade de vida”, "enfatiza a participação comunitária”, "pela abrangência”, "porque oportuniza discutir "Novamente comprei a idéia", disse Vanderlei Negro, presidente da ABECA (Associação dos Contabilistas), referindo-se, especificamente, ao convite que lhe foi feito pela Prefeitura Municipal, para participar da apresentação do Projeto Cidade Saudável pelo Dr. Jack Lee: "tenho muito gosto em participar, quer como representante da ABECA, quer como simples cidadão Jundiaiense, contribuindo para a melhoria da qualidade de vida geral".

O coordenador do GAC (Grupo de Apoio à Comunidade da Vila Arens), Gerson Marques da Silva, salienta que é muito importante a participação dos moradores. Ele explica que as pessoas poderão expor as necessidades do bairro, os aspectos que podem ser melhorados, quais são as prioridades e depois discuti-las com representantes de cada área que estarão presentes.

Nós pretendemos ir implantando o projeto bairro por bairro até conseguir unir toda a cidade" , diz Maria Cristina Figueiredo, presidente do Instituto de Arquitetos do Brasil (IAB) núcleo Jundiaí.

"O projeto Jundiaí Cidade Saudável pressupõe duas coisas para funcionar: o planejamento e a participação de toda a sociedade civil de forma consciente e engajada. Sem isso ele não funciona" , afirma o engenheiro César Augusto Traldi, da Associação dos Engenheiros (DSC das organizações da sociedade civil)

qualidade de vida e cidadania”.

Os jornais locais nos anos de 1994 e 1995 divulgaram as expectativas que indivíduos, grupos e organizações locais tinham em relação ao Projeto. Mostram motivação e interesse em disseminar a idéia de uma Cidade Saudável, e concretizar propostas de ação nos bairros. Por esses depoimentos pode-se verificar também que 
essas instituições tinham uma grande esperança que o PJCS fosse, aos poucos, atingindo todos bairros da cidade (DSC das organizações da sociedade civil). ${ }^{29}$

Observamos maior participação no PJCS de representantes de associações de classe da cidade, que se inserem em várias iniciativas que dizem respeito ao desenvolvimento da cidade. Por exemplo, a Ação Pró-Jundiaí, formada por um grupo bastante heterogêneo, como líderes empresariais, integrantes de partidos políticos, representantes de associações de classe, etc. De acordo com um de seus coordenadores, foi considerada o "braço do PJCS". Sem vinculação partidária, foi criada no final dos anos de 1980, com o objetivo de propor mudanças na prática política da cidade, fortalecer as políticas sociais, como segurança pública, saúde, educação, desenvolvimento territorial, bem como fomentar a discussão da democratização das ações partidárias, visando fortalecer os partidos políticos. Atuante na década de 90, hoje a APJ se encontra de acordo com seu ex-coordenador em "estado catalítico". Outro importante segmento que pouco se envolveu com o PJCS foi o Instituto Serra do Japi, que foi fundado em 1996.

Deste conjunto de representantes, que discutiu desde o ano de 1994 a implementação do PJCS na cidade, há um agrupamento que participa ainda hoje do Comitê Cidade Saudável e se reúne quinzenalmente na definição de estratégias de continuidade e que pode ser considerado o grupo atuante no Comitê Cidade Saudável, conforme ilustrado na figura 13. Nesta representação do Mapa de Integração e Participação no Projeto Jundiaí Cidade Saudável estão simbolizados os atores que participam, (figuras amarelas e brancas) e aqueles que deixaram de participar, ou nunca tiveram participação no PJCS (figuras azuis).

\footnotetext{
${ }^{29}$ Fonte: Jornais da cidade de Jundiaí. Ver referências $n^{\circ} 14 ; n^{\circ} 20 ; n^{\circ} 27$.
} 


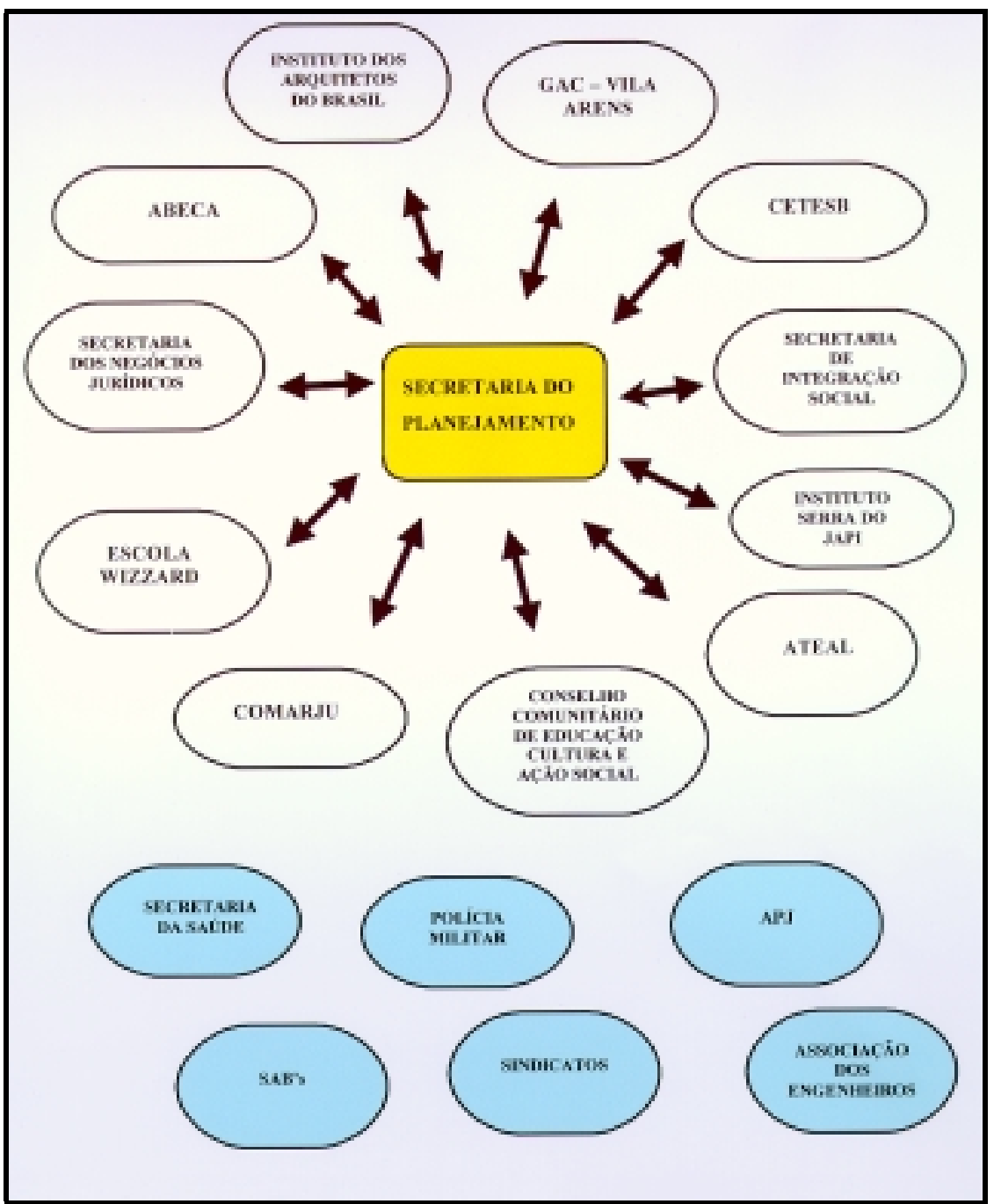

Figura 13. Mapa de Integração e Participação no Projeto Jundiaí Cidade Saudável

Esta representação atual do Mapa de Integração e Participação (participantes nos anos de 1998/1999) permite constatar que vários grupos que estiveram presentes de forma bastante efetiva nos primeiros anos do PJCS não participam mais das suas ações. Os exemplos da Polícia Militar e da Associação dos Engenheiros são ilustrativos. A PM tem representação esporádica no Comitê, embora ainda realize o programa Polícia Comunitária, um dos projetos que alicerçou o PJCS na sua origem. É o caso também da Associação dos Engenheiros, que teve atuação bastante significativa no início do Projeto e hoje não participa mais. Seu representante afirma que deixou de participar porque se desmotivou diante das mudanças administrativas quando o governo pretendia oficializar o Projeto.

Este argumento também é usado por muitos dos representantes da administração, especialmente ligados às Secretarias da Saúde e do Planejamento que 
deixaram de participar do Projeto: com a oficialização do Projeto, os integrantes das secretarias municipais passaram a ser nomeados através de portaria.

Causa estranheza o fato do segmento da saúde estar fora do Projeto nos dias de hoje. O Secretário da Saúde atual se diz desinformado da situação em que se encontra o PJCS e afirma que nunca foi convidado a participar de suas atividades. O Conselho Municipal de Saúde de Jundiaí, que está vivendo um conflito com a administração da Prefeitura, declarou através de seu presidente, descrença nos rumos do PJCS. O Conselho teve uma participação esporádica em algumas reuniões e considera este um Projeto "programado para desaquecer".

Os sindicatos da cidade nunca tiveram participação no Projeto. Dois sindicatos contatados revelam profunda indiferença ao Projeto Jundiaí Cidade Saudável. O Sindicato dos Trabalhadores nas Indústrias de Alimentos e Bebidas, que funciona desde 1954 e tem 1800 filiados, avaliou que a idéia Cidade Saudável foi instituída pela prefeitura local como marketing político. O diretor sindical lembrou que os canadenses estiveram na cidade e que classificaram Jundiaí como uma das cidades mais saudáveis do Brasil, mas ressaltou que muito embora Jundiaí seja uma cidade sem problemas graves de infra-estrutura, a situação de saúde é preocupante. Quando perguntado porque o sindicato nunca participou das atividades do PJCS, foi enfático:
"Nunca fomos convidados, este Projeto ficou restrito aos capa-preta da Prefeitura, que pensaram, idealizaram e jogaram na mídia. A mídia é totalmente dependente da administração. É fácil passar uma idéia".

O Sindicato dos Bancários, que existe na cidade desde o ano de 1986 conta com 1400 filiados, e participa do Conselho Municipal de Saúde tem a mesma opinião. Considera que a prefeitura da cidade fez muita propaganda em torno do Cidade Saudável e que essa não é a realidade do município.

Neste contexto, fica colocada uma das complexidades da participação: a representatividade. O grupo que constitui hoje o Comitê Cidade Saudável tem diferentes posições sobre este tema. Alguns membros afirmam que este Comitê não representa os anseios da sociedade como um todo, justamente porque não estão agregados os setores que sofrem as conseqüências de uma cidade não saudável: 
Cidades Saudáveis no Brasil e os processos participativos: os casos de Jundiaí e Maceió

"Eu afirmo que nós não somos
representativos, não estou desmerecendo
ninguém, eu acho que somos geradores de
idéias" (GF1, em 18/08/99).

Outros, porém, acreditam que a representatividade é relativa, mas que ela é importante porque de certa forma garantiu a continuidade do Projeto:

"Representa sim, não talvez com uma
dimensão que a gente gostaria, mas de certa
forma o grupo representa alguns setores da
sociedade..." (GF1, em 18/08/99).
"Tem outra coisa, o projeto anda devagar, se
nós convidamos 100 pessoas e vem 5, você
tem razão, a representação não é aquilo que
gostaríamos todos nós, mas se os outros
deixaram na nossa mão, por desistência, por
não vir, o Projeto não pode morrer por causa
disso, então temos que assumir essa
representatividade" (GF1, em 18/08/99).

Este Comitê é considerado executor, e foi criado para agilizar as decisões do Conselho da Cidade Saudável, que deveria ser o órgão decisório ampliado com a participação dos mais diversos setores da sociedade civil, "cidadãos que tinham influência na sociedade", incluindo diversas associações amigos de bairros. Este Conselho reuniu-se algumas vezes e chegou a contar com a participação de "mais de 100 pessoas". No entanto, está sem atuação há 2 anos:

"Esse Conselho não existe mais? Existe, mas ficou tanto tempo abandonado, dois anos, que na convocação uma ou outra pessoa que falou comigo sobre isso pensou que o Projeto tivesse morrido ..." (GF1, em 18/08/99).

A participação de associações se dá através de diversas iniciativas na cidade de Jundiaí, mas de acordo com um de seus ex-coordenadores, está restrita a uma "elite gerencial", "muito ágil, muito operante, mas pequena". Por isso, explica que, embora haja um grande número de conselhos institucionalizados e organizações atuantes, as pessoas que os constituem são sempre as mesmas:

"Então, uma pessoa é da Ação Pró-Jundiaí é ao mesmo tempo do Conselho de Segurança. Alguém que é da Cidade Saudável, está dentro da FUMAS" (EC2). 
Reconhece, entretanto, que há um forte potencial de participação na cidade como um todo:

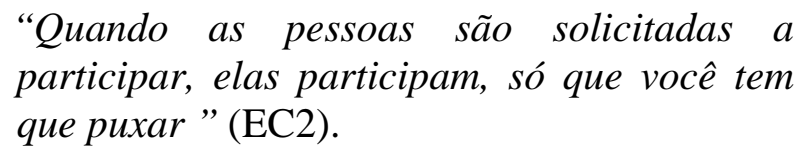

As lideranças dos bairros são bastante atuantes, são reconhecidas nos bairros, e se constituem em articuladores com o poder público:

"Você vai detectar essa participação pelo
carisma do líder, pela história do líder dentro
do bairro, que é alguém que tem uma relação
com a administração pública razoável e
consegue benefícios para o bairro, uma
praça, um poste de iluminação...." (EC2).

Algumas pessoas que acompanharam o processo de desenvolvimento do PJSC relataram suas percepções em relação às mudanças que se deram no Projeto nesses cinco anos de existência, enfatizando a relação que o poder público estabeleceu com os grupos da população.

Para o ex-coordenador do Planejamento do município, o PJCS pode ser analisado a partir de duas fases distintas. A primeira, que contou com uma equipe de excelente nível técnico, envolvida com os pressupostos e o ideário do Projeto. Houve a efetiva participação da sociedade civil, relatou, referindo-se à formação dos comitês e aos trabalhos desenvolvidos na Vila Arens. Nesse período implementou-se também o Fórum dos Conselhos Municipais, sob a coordenação do PJCS. A fase que antecedeu às eleições de 1996, no entanto, trouxe mudanças na administração. A Secretária da Saúde, se desligou da prefeitura e ele, como coordenador do Planejamento, esteve muito envolvido com o plano de governo do sucessor, o que acabou afastando dois importantes articuladores do governo:

$$
\begin{aligned}
& \text { “...nós entendíamos na época que o bom do } \\
& \text { Projeto seria que a sociedade estivesse } \\
& \text { assumindo a coordenação e o comando e } \\
& \text { cada vez mais deveria ser mais sociedade e } \\
& \text { menos poder público...." (ESP). }
\end{aligned}
$$

$\mathrm{O}$ afastamento do poder público fez com que as entidades também se afastassem, segundo a avaliação do ex-coordenador. De acordo com ele, num 
primeiro momento o PJCS teve um desenvolvimento bastante intenso exatamente porque o poder público supria todas as necessidades técnicas e materiais do Projeto, com funcionários que trabalhavam nele em tempo integral e com amplo apoio de duas importantes áreas de governo: a da Saúde e a do Planejamento:

“... nós tínhamos todos os espaços da
prefeitura para articular, por exemplo esse
fórum dos Conselhos Municipais. E as
entidades todas sentiam a importância do
Projeto porque sentiam que a prefeitura
apoiava intensamente ...” (ESP).
“... faltou um pouco de poder de organização
(das organizações da sociedade civil), porque
é mais fácil quando você tem uma pessoa da
prefeitura full time, trabalhando com todos os
recursos e com acesso a informação e com
facilidade de articular grupos ...” (ESP).

A segunda fase, à qual se refere o ex-coordenador do Planejamento do município, diz respeito àquela que se iniciou a partir da nova gestão municipal. Com a mudança de administração municipal, houve troca na coordenação do Projeto e um esvaziamento dos canais institucionais de participação, como os conselhos municipais. Esta saída de pessoas com domínio dos canais de interlocução e um certo domínio de conceitos e pressupostos foi bastante sentida por parte da equipe que permaneceu no Projeto:

"Os antigos não consolidam conceitos, fica difícil com a entrada de pessoas novas. $O$ processo emperra."

Para o ex-coordenador do PJCS, durante a gestão que durou até o ano de 1996, o projeto se constituiu numa força política muito grande. O Fórum dos Conselhos, por exemplo, tornou-se um importante espaço de articulação para a construção de relações políticas. Embora tenha havido continuidade partidária, uma vez que o vice-prefeito da gestão anterior foi eleito prefeito, e a expectativa era de que ele tivesse uma postura ideológica avançada e desse continuidade às discussões e ações já empreendidas, observou-se o contrário. Manteve o projeto sob uma coordenação formal, criando um afastamento das organizações da sociedade civil. Ou seja, a administração deixou de impulsionar e incentivar os processos 
participativos que estavam presentes no início da formulação do Projeto na cidade, o que acabou enfraquecendo ainda mais a relação do governo com os grupos sociais.

Certos setores questionam a relação entre o governo e as organizações que participam do PJCS. Para eles esta relação é "frágil" e tem sido uma das dificuldades em avançar com o Projeto. No grupo focal com o Comitê Cidade Saudável este aspecto foi abordado:

Coord.:- "por que é frágil?"
"ela é frágil porque a abertura é muito nova"
"não porque a abertura é muito nova, é o
medo, o medo que a gente tem de perder a
abertura nos faz recuar e não avançar... ... a
gente não sabe até onde pode avançar, a
medida que você não avança você deixa as
coisas acontecerem, com medo de perder o
espaço que foi conquistado ..." (GF1, em
18/08/99).

O atual secretário do Planejamento, área em que o PJCS está localizado, entende que o Projeto Cidade Saudável passa por dificuldades, e a culpa recai sempre sobre o poder público. Para ele o ponto mais frágil, no entanto, não está na relação governo/sociedade, mas diz respeito à "falta de definição dos objetivos e da especificidade do Projeto." Ele entende que todos querem uma cidade saudável, mas seria necessário construir uma metodologia na busca de melhoria de qualidade de vida. Sem dúvida, crê que os concursos deram visibilidade à idéia, mas questiona: " $o$ objetivo do Projeto é realizar concursos?" E termina, "se não encontra sua especificidade, o Projeto vai continuar dependendo de pessoas, não encontrando identidade nunca vai conseguir se consolidar na cidade."

A relação poder público/sociedade assume conotação diferente quando se trata dos coordenadores do PJCS. Foram 3 coordenações, de 1994 a 1999, todas ligadas ao governo municipal. Para os representantes da sociedade civil, as duas primeiras coordenações podem ser consideradas "de continuidade", pois buscavam fortalecer os segmentos populares, promovendo um diálogo constante entre a sociedade civil e o governo municipal, criando até canais de participação na administração pública. Houve, desta forma, uma sintonia de interesses e uma concordância com o ideário da administração, o que trouxe benefícios no 
desenvolvimento de ações, especialmente nos anos de 1995 e 1996. No entanto, sob a $3^{\mathrm{a}}$ coordenação, já na nova administração eleita em 1997, deu-se ao Projeto uma característica mais administrativa, o que acabou resultando em esvaziamento das relações que vinham se estabelecendo anteriormente.

O $3^{\circ}$ coordenador do PJCS justifica a intenção de formalizar o Projeto por meio de um decreto municipal. Para ele, o objetivo foi dar ao Projeto um corpo, porque até então "só teve alma":

"Nós estamos constituindo o Comitê
Executivo do Projeto com membros da
sociedade civil organizada em parceria com a
administração pública. E esses dois blocos
vão ser nomeados, nós vamos expedir uma
portaria, que é um ato do chefe do executivo,
nomeando essas pessoas, porque é
interessante que eles tenham clareza que
estão sendo nomeados para exercer essa
atribuição. Essas pessoas nomeadas vão
praticar políticas públicas saudáveis" (EC3).

Muitas pessoas que acompanharam o processo de implantação do PJCS, especialmente aquelas da administração pública têm críticas contundentes à organização do PJCS sob essa coordenação, que preocupava-se muito mais em formalizar a participação das pessoas:

"As pessoas participam, mas estavam sendo guiadas. Isto é que precisa mudar. Desanima participar de reunião e as pessoas começam a listar coisas para fazer. Hoje é ainda um Projeto perdido. Todos querem se transformar em executivos. "

O Discurso do Sujeito Coletivo (DSC) da Coordenação do Projeto, construído a partir das matérias publicadas pelos jornais locais nos anos de 1994 a 1996, revela a importância política e estratégia desses técnicos, que explicitavam os pressupostos conceituais, definiam as ações, eram os interlocutores entre o governo e a sociedade 
civil, mediavam a relação com o Canadá e definiam estratégias de continuidade (DSC das Coordenações do PJCS) ${ }^{30}$.

O assessor técnico de Coordenadoria de Planejamento, nomeado coordenador de comissão, Paulo Fernando Capucci, afirmou que os representantes deverão preparar um relatório sobre as atividades desenvolvidas, a fim de analisar as condições da cidade.

O coordenador explicou que sete cidades estarão participando do programa no Brasil, a fim de promover a criação de uma rede da Cidades Saudáveis. Disse ainda que, a partir da próxima semana, a Secretaria de Saúde e a Coordenadoria de Planejamento devem iniciar uma série de reuniões promovendo a continuidade das discussões sobre o projeto Cidades Saudáveis.

A Coordenadoria de Planejamento e a Secretaria de Saúde realizaram hoje a segunda reunião da comissão responsável pela elaboração do programa Cidade Saudável. O assessor técnico, Paulo Fernando Capucci, afirmou que a reunião deverá definir o encaminhamento do trabalho e que a equipe deverá concluir hoje o trabalho de levantamento das informações para a apresentação do primeiro relatório. Afirmou, ainda, que já foram realizadas duas reuniões, para de estabelecer o calendário de trabalho e discutir as prioridades do programa.

"A idéia é definir o background, dimensionando as propostas", comentou. De acordo com o coordenador, está sendo organizado também um documento detalhado para a avaliação e divulgação do programa para a comunidade

Capucci considerou positivo o resultado do encontro, destacando o interesse do grupo em dimensionar a estratégia de trabalho para a conclusão do programa. Informou que foram identificados quatro projetos para integrar o "Jundiaí Cidade Saudável": o Cata Treco, o Conheça seu Bairro, o Policiamento de Bairro e Educação de Trânsito

Paulo Capucci expôs aos moradores da Vila Arens - em reunião realizada no salão paroquial da igreja Nossa Senhora da Conceição - ontem à noite, as linhas básicas do projeto, em grande parte já levado adiante pelo Grupo de Apoio à Comunidade (GAC) da Vila Arens: "já temos pessoas se organizando nesse sentido em outros bairros, no Anhangabaú, Vila Hortolândia e Distrito Industrial", diz o Capucci. Ele disse ainda que a importância do encontro com os canadenses foi estabelecer uma agenda de discussões e ajuda mútua. O próximo passo é ter diagnósticos dos problemas e trocar experiências de ajuda mútua.

De acordo com um dos coordenadores do Projeto Jundiaí Cidade Saudável, Sérgio Pio Bernardes, a cidade conta com bons exemplos da preocupação da Administração com a qualidade de vida da população. Para este ano, segundo Bernardes, entre as diversas estratégias do projeto estão a criação de um novo concurso

śrgio Pio Bernardes, disse que o objetivo é atingir 85 mil estudantes.

As eleições de 1996 acabaram gerando a iniciativa de se promover debates entre os 4 candidatos à sucessão municipal. Capucci explicou que estes encontros visam aprofundar a visão dos políticos locais, em favor de uma cidade saudável. Queremos discutir com os cabeças de chapa a construção de uma cidade melhor. Temos uma série de pontos e sugestões para fazer .Nestes encontros pretendemos apresentar o estágio de desenvolvimento do projeto aos candidatos e ouvir os planos que eles têm para favorecer um desenvolvimento saudável e sustentável para a nossa cidade e região (DSC das Coordenações do PJCS).

\section{ALCANCES E LIMITES DA POLÍTICA IMPLANTADA}

\section{A experiência do Projeto Jundiaí Cidade Saudável se caracteriza pela} afirmação, no seu ideário, do desenvolvimento de uma cidade saudável, por meio de políticas integradas, com a efetiva participação de todas as áreas de governo e dos

${ }^{30}$ Fonte: Jornais da cidade de Jundiaí. Ver referências $\mathrm{n}^{\circ} 9 ; \mathrm{n}^{\circ} 1 ; \mathrm{n}^{\circ} 10 ; \mathrm{n}^{\circ} 11 ; \mathrm{n}^{\circ} 13 ; \mathrm{n}^{\circ} 15 ; \mathrm{n}^{\circ} 16 ; \mathrm{n}^{\circ} 24 ; \mathrm{n}^{\circ} 27 ; \mathrm{n}^{\circ} 29 ; \mathrm{n}^{\circ} 30 ; \mathrm{n}^{\circ} 31 ; \mathrm{n}^{\circ} 54 ; \mathrm{n}^{\circ} 55 ; \mathrm{n}^{\circ} 61 ; \mathrm{n}^{\circ} 68 ; \mathrm{n}^{\circ} 56$. 
segmentos da comunidade local. Contudo, um dos eixos norteadores da proposta, a intersetorialidade, nunca chegou a ser implementada através do Projeto, embora, em seus momentos iniciais, tenha se conseguido aglutinar esforços e tentado conduzir projetos nesta perspectiva. Se há programas sendo desenvolvidos com um desenho intersetorial, e que dão respostas integradas, esses vêm sendo realizados sem qualquer vinculação com o Projeto.

Em suma, o PJCS tornou-se um apêndice na Secretaria do Planejamento e não tem qualquer papel na definição de políticas. Este é um dos grandes problemas referidos por ALMEIDA (1997), quando ressalta que ao se tornarem paralelos, projetos e programas, não têm qualquer impacto na realidade ou no contexto político das cidades.

Como destaca VIANA (1998), a forma de integrar ações intersetoriais exige estabelecer compromissos públicos e de cooperação social, entendida como um mecanismo que reforça a idéia da cidadania ativa (direitos e responsabilidade).

O compromisso político tem um papel fundamental no sucesso de iniciativas Cidades Saudáveis e na definição de políticas nessa perspectiva (ALMEIDA 1997; GOUMANS 1997). O compromisso do governo de Jundiaí com as propostas do PJCS foi oscilante nesses seis anos de existência do Projeto. Em princípio, o governo local teve um papel estimulador e articulador dos diversos segmentos da administração e da sociedade local, e entendia que o Projeto significava uma possibilidade de se pensar um modelo alternativo de gestão municipal.

Neste período, todos os órgãos de governo participaram e se inseriram, alguns mais outros menos, nas definições relacionadas aos destinos do PJCS. Num momento seguinte, após a mudança de governo municipal, quando se esperava receber apoio político para a continuidade do Projeto, já que o prefeito pertencia ao mesmo partido político de seu antecessor, observou-se que esta discussão ficou restrita ao âmbito de poucos setores da prefeitura. Afastaram-se setores importantes, como os da educação, o de saúde, o de meio ambiente, e o governo manteve uma posição de indiferença em relação aos seus rumos, ausentando-se freqüentemente dos poucos fóruns de discussão que ainda ocorreram. Nesse período, também finalizou o apoio técnico que os canadenses vinham dando ao desenvolvimento do ideário na cidade. 
Pode-se levantar como hipótese, que nos primeiros anos de existência, o Projeto esteve ligado a um grupo muito restrito de indivíduos, impulsionadores da idéia, interlocutores com instituições externas, que não conseguiu, num momento seguinte, apoio político para inseri-lo na nova agenda política que estava se estabelecendo. Sem compromisso político do gestor, o PJCS continua, nos dias de hoje, apenas como um ponto de discussão entre aqueles que ainda crêem nos seus princípios, mas que não têm qualquer força política para alterar essa situação.

A análise da participação dos grupos e associações, outro componente prioritário do PJCS, revelou alguns aspectos importantes. A presença de lideranças em diversas áreas da cidade aponta que há um potencial para a participação, que acabou se ampliando com as discussões do Projeto. Há indícios, portanto, de que o Projeto promoveu a colaboração entre os membros da comunidade e que este foi o maior salto que se pôde alcançar, já que os movimentos que existiam na cidade eram desarticulados entre si e encontraram na agenda da Cidade Saudável um referencial comum, através do Conselho da Cidade Saudável e do Comitê Executivo do PJCS.

No que se refere aos atores envolvidos no PJCS, observa-se uma distância significativa entre o que se esperava na formulação inicial do Projeto e o que se apresenta nos dias de hoje. Este grupo é relativamente frágil em sua organização e estabelece relações individuais e diretas com a administração municipal. Como pudemos revelar, importantes atores do governo local e da sociedade civil estão fora das discussões do Projeto, o que compromete significativamente os seus rumos. Apesar de suas fragilidades organizativas, a participação da sociedade civil é o ponto de sustentação do ideário do Projeto na cidade de Jundiaí. Embora o grupo do Comitê Cidade Saudável reconheça que não representa as classes populares da cidade, que podem ter outros anseios, necessidades e demandas, ainda tem feito esforços para ampliar os debates nos bairros.

Apesar das dificuldades, o Comitê Cidade Saudável, que participou do grupo focal em 18 de agosto de 1999, afirmou que há possibilidades de retomar e fortalecer o PJCS na cidade. Mas refere que isso requer: ampliar a participação da sociedade, ou resgatar o movimento inicial que tentou aglutinar os mais diversos segmentos dos grupos organizados da cidade no Conselho Cidade Saudável; realizar um processo de 
sensibilização nos bairros e rediscutir a representatividade no Projeto; ampliar as discussões para as cidades vizinhas e iniciar um movimento por uma região saudável e retomar os contatos com a mídia local, no sentido de dar continuidade à publicização do Cidade Saudável.

Ainda de acordo com os participantes do Projeto, algumas atividades tiveram grande impacto na cidade, pelo menos quanto à sensibilização. Por exemplo, os concursos que envolveram a rede pública de educação e promoveram a discussão sobre o meio ambiente, a influência das políticas públicas na qualidade de vida, a relação do homem e meio ambiente. Afirmam que o maior impacto foi na área de educação, mais especificamente no campo da educação ambiental, e que por isso este processo não pode ser abandonado. As iniciativas de dar continuidade aos concursos junto às escolas, no entanto, parecem não mobilizar as pessoas como o faziam antes, justamente por estarem totalmente descolados de uma proposta mais global de definição de uma política de gestão para a cidade.

Pode-se afirmar que a experiência do PJCS configura as contradições decorrentes da relação Estado/sociedade civil em todas as suas dimensões. A institucionalidade desta relação, bem como a normatização das arenas de negociação estão colocadas. Por um lado, há reconhecimento por parte dos segmentos sociais organizados de que o Estado não é o inimigo, pode ser um interlocutor, um parceiro na construção de uma cidade saudável. A agenda do poder público contempla esta integração com a sociedade civil, mas esta integração está cercada de fragilidade, especialmente sentida pelos grupos organizados, que têm dificuldades em penetrar no espaço institucional e exercer o controle social. O poder público estabelece as regras da participação, como e onde se darão. É tímida a intervenção da sociedade civil, que tem potencial e vontade de inovar, mas fica sempre na espera do momento político mais favorável. A mudança de governo e o desaquecimento do PJCS atestam este fato. Quando o Projeto foi conduzido pelo poder público, tendo sido coordenado por técnicos que reconheciam nos grupos organizados seus aliados e parceiros efetivos, tomou proporções de projeto capaz de alterar práticas políticas consolidadas. Com as mudanças, os grupos organizados recuam, fazendo crer que o ciclo de fluxos e refluxos presentes nas políticas locais, bem como o papel exercido pelo poder público, podem reduzir as possibilidades de uma participação mais efetiva e uma 
Cidades Saudáveis no Brasil e os processos participativos: os casos de Jundiaí e Maceió

ampliação do espaço público como espaço de exercício da cidadania e de democratização da gestão.

Nessas considerações finais é preciso ressaltar que a mídia teve um papel importante na disseminação do ideário na cidade. Chama a atenção o fato de que é através do poder público e da coordenação do PJCS, também representante do governo - principais interlocutores do PJCS com a mídia da cidade de Jundiaí - que os conceitos e as etapas do processo histórico são enunciados. O discurso dos representantes dos grupos organizados da população que fazem parte do PJCS é menos presente nos artigos publicados e usualmente reforçam o conteúdo expresso pelos representantes do governo. Assim, pode-se revelar a força de expressão do poder público como fonte de informação. A ausência de matérias publicadas, no ano de 1999, justamente quando o PJCS perde sua visibilidade como política pública de governo, pode sugerir que os fatos são gerados pela prefeitura, que tem acesso privilegiado a esses meios de comunicação, tendo mais condições de manifestar seus interesses por meio da imprensa e, assim, influir na opinião pública.

Finalmente, pode-se concluir que a soma vários aspectos contribuíram para a desaquecimento do Projeto Jundiaí Cidade Saudável e impediram o estabelecimento de mecanismos mais eficazes de continuidade do Projeto: falta de definição em relação aos objetivos do Projeto, falta de compromisso político dos governantes da cidade, fragilidades decorrentes dos processos participativos, inexistência de apoio técnico e monitoramento continuado das ações. O que se tem hoje é a manutenção do ideário por um grupo muito restrito, que tem dificuldades e pouco espaço político para promover debates sobre os rumos do Projeto Jundiaí Cidade Saudável, visando a revisão e formulação de seus objetivos. 


\section{Comunidades Saudáveis em Maceió: Pontal da Barra e Cruz das Almas}

\section{A CIDADE DE MACEIó}

\section{História}

Maçai-ó-k, Massayó, Massai-ó-k e Maçaió-k são as diversas grafias utilizadas para designar como os índios definiam o trecho de um rio, "aquele que represa o alagadiço". Essa denominação, depois modificada para Maceió, define a topografia da cidade, um alagadiço que se espraia até encontrar a lagoa do Mundaú. Contam os historiadores que o território alagoano antes da chegada das primeiras expedições portuguesas era ocupado por Potiguaras, Tabajaras, Caetés, Abacatiaras, Aconans, Cariris, Coropatis e outras tribos. No período da colonização, início do século XVI, portugueses e franceses disputavam a extração de pau-brasil na região, até a definição por parte da corte portuguesa de delimitar as capitanias hereditárias. A capitania de Pernambuco, criada em 1534, estendendo-se do Rio São Francisco ao Sul, até o Maranhão ao Norte, compreendeu todo o território onde hoje é o Estado de Alagoas.

Dizem os historiadores: "as grandes extensões de terra que compunham as capitanias, as dificuldades em povoá-las, as exigências sociais e materiais das populações já estabelecidas e a conveniência da exploração sistemática do solo, propício a todas as culturas, aconselhavam a divisão das mesmas em sesmarias, distribuídas entre os colonos mais notáveis -os chamados homens de qualidade". (PMM 1995, p.25). Sabe-se que a primeira alusão ao sítio Massayó data de 1787, numa escritura de doação. Este talvez tenha sido o ponto de irradiação para o núcleo que foi sendo formado. No final do século XVIII, Maceió era apenas um povoado, que foi progredindo dada a existência do porto de Jaraguá e sua ligação com duas principais vilas da época: Porto Calvo e Alagoas. No final do período colonial Maceió já possuía um pequeno centro comercial, em 1815 a povoação foi elevada à categoria de Vila e em 1839 tornou-se uma cidade e sede do governo provincial.

O crescimento do comércio portuário, em decorrência da implantação do Porto de Maceió, principal polo de escoamento do Estado, e segundo maior porto do Nordeste responsável pelas atividades de importação e exportação, a proliferação de 
indústrias de diferentes ramos de atividade e o incremento do turismo, fizeram com que Maceió se tornasse a principal cidade de Alagoas.

O fato de ser uma cidade-porto localizada na metade do litoral dos Estado de Alagoas, faz com que se constitua no mais importante centro comercial do Estado.

\section{Perfil demográfico e infra-estrutura urbana de Maceió}

O Estado de Alagoas, de acordo com os dados da Contagem da População do IBGE de 1996, tem um total de 2633339 habitantes. Maceió, capital do Estado, com 723230 habitantes, concentra 27,46 \% do efetivo populacional do Estado. A população masculina é de 340.258 habitantes e a feminina é de 382.972 habitantes (IBGE 1997).

Segundo os estudos do IPEA/IBGE/UNICAMP (1999), a Aglomeração Urbana de Maceió é formada por áreas urbanas dos municípios de Maceió, Rio Largo, Pilar, Marechal Deodoro, Satuba, Santa Luzia do Norte e apresentou, no período de 1980-1991, um elevado incremento populacional, o que mostra um alto padrão de migração ruralurbano (figura 14).

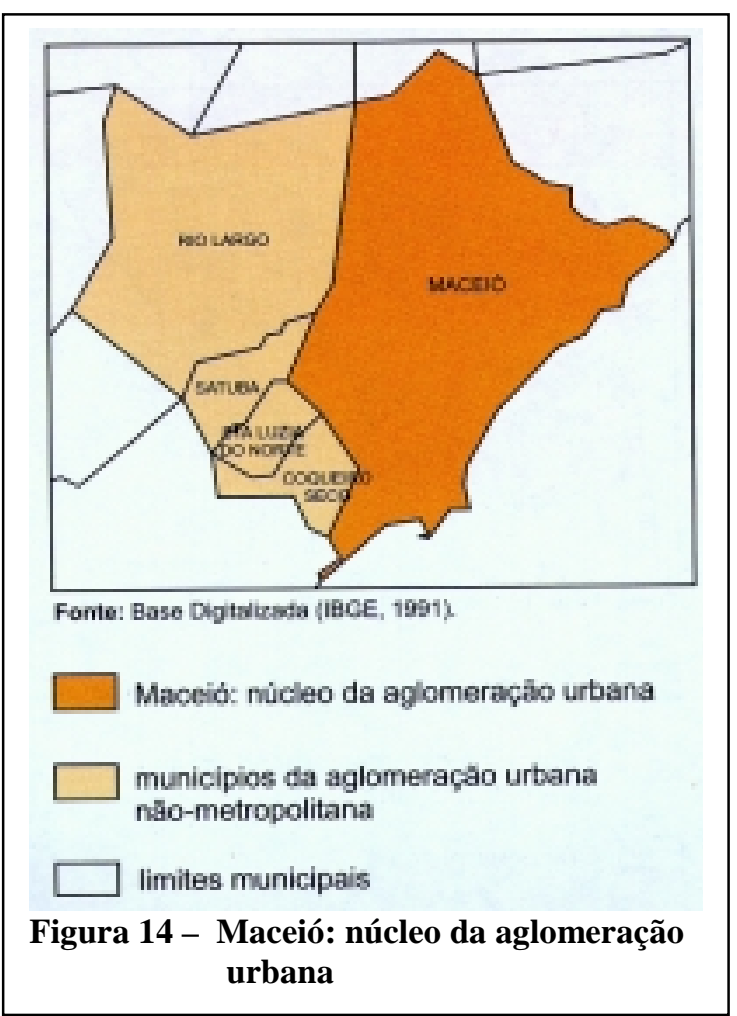

O Censo Demográfico de 1991 já revelava a continuidade do processo de urbanização que vinha ocorrendo no Estado desde os anos de 1980, passando de 49,2\% em 1980, para 58,9\% em 1991. A tendência à urbanização continua nos anos seguintes, chegando a 63,1\% em 1996. Maceió é um município basicamente urbano, superando os índices do Estado. Na área urbana residem 667915 habitantes e na área rural 55315 habitantes, representando um índice de urbanização de 92,3\%.

A expansão urbana desenvolveu-se sobre duas planícies interligadas por encostas naturais, que apesar de serem impróprias à ocupação, são habitadas. Maceió é uma cidade que apresenta contrastes bastante acentuados. Enquanto uma parcela da 
Cidades Saudáveis no Brasil e os processos participativos: os casos de Jundiaí e Maceió

população vive na orla, ou em regiões dotadas de infra-estrutura básica e comércio, a outra parte da população, mais desfavorecida, concentra-se no cinturão periférico da cidade, especialmente nas encostas. Predominam nesses locais situações de irregularidades, improvisos e insegurança.

O Índice de Desenvolvimento Humano (IDH) do Programa das Nações Unidas para o Desenvolvimento (PNUD) indica que Maceió apresenta um médio desenvolvimento humano - 0,744 , muito superior ao índice considerado para o Estado de Alagoas - 0,474, que representa o terceiro pior índice do país, ficando atrás apenas do Piauí, 0,468 e do Maranhão, 0,456 (PNUD 1998).

Uma visão mais detalhada do ICV, Índice de Condição de Vida do PNUD, uma extensão do IDH que mostra os índices médios de renda, educação, infância, habitação e longevidade, permite apontar que Maceió tem taxas elevadas de mortalidade infantil, analfabetismo, baixa renda per capita, baixa cobertura de serviços de infra-estrutura básica, muito embora apresente os melhores índices do Estado e superiores à média do Estado de Alagoas, e venha melhorando substancialmente esses índices ao longo dos últimos 20 anos. O estudo da alfabetização, por exemplo, que privilegia o enfoque do analfabetismo, utilizando o corte de 15 anos ou mais, mostra que as taxas de analfabetismo em Maceió vêm decrescendo na última década, embora a proporção de analfabetos ainda seja considerada elevada. De acordo com o PNUD, para as pessoas de 15 anos e mais, a taxa de analfabetismo, em Alagoas, sofreu decréscimo nos últimos 11 anos, passando de 54\% em 1980, para 44\%, em 1991. Comparado aos outros municípios Maceió apresenta a menor taxa de analfabetismo do Estado para pessoas de 15 anos ou mais, 21,1\% em 1991.A tabela 7 abaixo ilustra alguns desses índices.

O saneamento é um dos maiores problemas da cidade, agravado pela situação atual do emissário submarino. Os dejetos são lançados ao mar através do emissário que está há dezoito anos sem manutenção e não tem capacidade de suportar aumento do número de ligações.

O Índice Municipal dos 187 maiores municípios do Brasil, construído pelo Instituto Pólis a partir de dez indicadores, permite observar a posição ocupada pelas 
capitais brasileiras e comparar Maceió com as demais ${ }^{31}$. Os 187 municípios com mais de 100 mil habitantes foram divididos em quatro grupos. No primeiro grupo, com índices mais altos, estão as capitais do Sul, do Sudeste e Brasília. No segundo grupo, estão as capitais do Centro-Oeste. No terceiro grupo, estão sete capitais do Nordeste, inclusive Maceió, (posição 133 e índice 0,550), além de Manaus e Belém. No quarto grupo estão quatro capitais do Norte e Teresina ( SOUTO e col 1997).

Tabela 7 - Índice de Condição de Vida de Maceió e Estado de Alagoas - 1980-1991

\begin{tabular}{|l|c|c|c|c|}
\hline \multirow{2}{*}{ INDICADOR } & \multicolumn{2}{c|}{ Maceió } & \multicolumn{2}{c|}{ Estado de Alagoas } \\
\cline { 2 - 5 } & $\mathbf{1 9 8 0}$ & $\mathbf{1 9 9 1}$ & $\mathbf{1 9 8 0}$ & $\mathbf{1 9 9 1}$ \\
\hline Índice de Condição de Vida (ICV) & 0,633 & 0,701 & 0,459 & 0,537 \\
\hline Esperança de vida ao nascer & 55,24 & 62,82 & 52,10 & 57,61 \\
\hline Mortalidade Infantil & 132,42 & 74,68 & 159,48 & 112,97 \\
\hline Taxa de analfabetismo & 25,9 & 21,1 & 54,0 & 44,0 \\
\hline$N^{\circ}$ médio de anos de estudo (25 anos ou +) & 4,6 & 6,0 & 1,8 & 3,1 \\
\hline Renda per capita média (SM/set 91) & 1,27 & 1,32 & 0,62 & 0,62 \\
\hline Abastecimento de água & 68,5 & 81,9 & 57,0 & 69,4 \\
\hline Instalação de esgotos & 30,0 & 43,3 & 36,1 & 21,7 \\
\hline
\end{tabular}

Fonte: PNUD, 1998

Este trabalho aponta também que a posição ocupada pela capital de Alagoas, segue a tendência das maioria das capitais brasileiras em relação aos outros municípios de seu Estado, apresentando índices mais elevados. Arapiraca, a segunda maior cidade do Estado, apresenta um Índice Municipal bastante inferior à capital, 0,352, localizando-se, portanto, no quarto grupo.

Como mostra a figura 15, Maceió localiza-se entre a Lagoa do Mundaú e o Oceano Atlântico.

A região metropolitana de Maceió está dividida em 50 bairros que constituem as sete regiões administrativas e sete distritos sanitários. As comunidades, o Pontal da Barra e as comunidade da Grota do Arroz, do São Rafael e Loteamento Santo Onofre do bairro de Cruz das Almas, selecionados para a experiência de

${ }^{31}$ Os 10 indicadores que compõem o Índice Municipal são: renda média, CH até 2 SM, Habit/domicílio, Cômodos, Dom. até 3 com., Água inadequada, Esgoto inadequado, Lixo inadequado, Analf. em + 15 anos, $\mathrm{Cr}$ c/ CH Analf. 
Comunidades Saudáveis, pertencem respectivamente à Segunda e Primeira regiões administrativas.

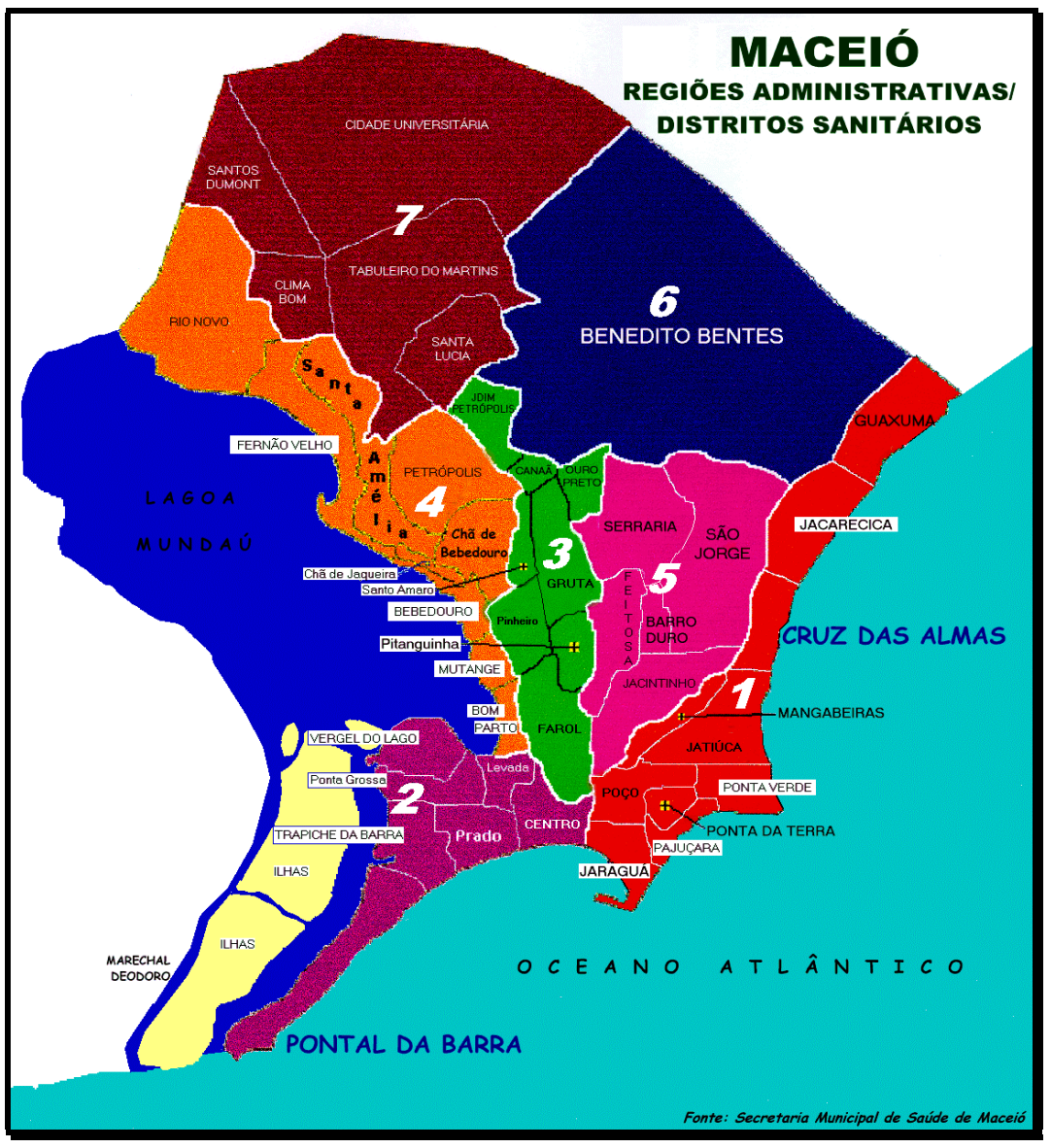

Figura 15 - Distritos do município de Maceió.

\section{O Projeto Comunidades SaUdáveis em Maceió}

Maceió inicia a discussão do Projeto Comunidades Saudáveis por meio do setor da saúde, após a participação da secretaria da saúde no I Encontro dos Secretários de Saúde das Américas, que ocorreu em Fortaleza, no ano de 1995, quando tomou conhecimento de projetos desenvolvidos no Canadá, que buscam a melhoria da qualidade de vida da população com base em implementação de ações intersetoriais e interinstitucionais. O relato da secretária de saúde de Maceió no ano de 1998, esclarece:

“...quando retornamos, amadurecemos essa idéia, que a gente queria realmente ter os parceiros para ter uma qualidade $100 \%$, ou melhorar a qualidade de vida. Aí sentamos para escrever o projeto onde a gente 
Cidades Saudáveis no Brasil e os processos participativos: os casos de Jundiaí e Maceió

pontuava todas essas questões do conceito de saudável, e de atribuições da saúde $e$ atribuições fora da saúde ...." (ES1).

De fato, o documento diretriz da Secretaria Municipal da Saúde de Maceió, que propõe O Projeto de implantação das comunidades saudáveis em Maceió para melhoria da qualidade de vida das populações em duas comunidades da cidade, reforça essa idéia. A saúde como resultado das condições de vida deve ser resultado da articulação e integração de ações e de recursos dos diversos órgãos da administração pública juntamente com as comunidades.

Esse documento delineia os pressupostos e objetivos iniciais do trabalho, definindo como principal meta: oportunizar a melhoria da qualidade de vida da população (PMM 1996). Os outros objetivos descritos dão uma idéia do alcance que o projeto pretendia atingir, envolvendo as comunidades através de suas organizações locais e implementando ações intersetoriais. Outras diretrizes centrais definidas nos projetos Cidades Saudáveis são:

- "criar a alternativa de conscientização e auto-estima;

- fortalecer lideranças e organizações existentes para o exercício da cidadania;

- estimular a formação do conselho gestor que garanta a participação dos trabalhadores da saúde e da comunidade;

- viabilizar atividades de prevenção e promoção à saúde mediante serviços, ações e as possibilidades dos postos de saúde e de outros setores ou órgãos;

- incentivar projetos e ou atividades de geração de renda; apoiar atividades culturais, recreativas e desportivas que contribuam para o exercício da cidadania" (PMM 1996).

Parte-se do suposto de que estes projetos serão construídos coletivamente com base em cada realidade e que profissionais de saúde, (grifo nosso), juntamente com as comunidades, serão provocados "a participarem criticamente da discussão dos problemas, necessidades, possibilidades e limitações” (PMM 1996). 
No relato de um membro da equipe técnica da Secretaria da Saúde verifica-se que esses projetos tinham um caráter experimental, e deveriam ser os primeiros de cinco. Não eram projetos pré-definidos e deveriam ser construídos no processo:

“...pequenas experiências onde nós
aprendêssemos, fazendo e executando, que
seria uma aprendizagem tanto dos técnicos
como também da própria população ...” (EC).

Os critérios que definiram a escolha dos bairros do Pontal da Barra e das comunidades vizinhas das Grotas do Arroz, do Rafael e Loteamento Santo Onofre, no bairro de Cruz das Almas para iniciar o projeto de Comunidades Saudáveis são distintos. O Pontal já contava com um projeto de revitalização, que objetivava incrementar o turismo local. Em linhas gerais, o projeto de Revitalização do Bairro do Pontal da Prefeitura Municipal de Maceió e da Empresa Municipal de Turismo de Maceió, previa, por meio de parcerias com o Banco Internacional de Desenvolvimento, a iniciativa privada e o setor público municipal e estadual, revitalizar o bairro por meio de melhorias de infra-estrutura e urbanização para o desenvolvimento socioeconômico cultural e turístico.

Além disso, a existência de associações e grupos comunitários atuantes no Pontal poderiam dar sustentação a um projeto de melhoria de qualidade de vida local.

As Grotas do Arroz, do São Rafael e o Loteamento Santo Onofre foram escolhidas por serem áreas geograficamente bem delimitadas, por terem uma população estável, de baixo poder aquisitivo e com pouca participação comunitária. Conclui-se "ser possível concentrar esforços, serviços, ações e, num determinado período avaliar mudança nas condições de vida e consequentemente de saúde" (PMM 1996).

Ainda que essas duas experiências tenham sido selecionadas para dar início a um projeto experimental, a prefeita da cidade entende que não é possível falar em um bairro saudável sem questionar a organização dos serviços que envolvem toda a cidade, bem como o acesso da população a esses serviços. Nesse sentido, os problemas e as dificuldades transcendem as comunidades estudadas:

"Antes de discutir o bairro saudável, a gente deve discutir os serviços da cidade, para que a gente construa uma cidade saudável. Como 
ter um bairro saudável se você não organizou os serviços, a educação, a saúde, os transportes coletivos, o acesso a população?"

\section{A intersetorialidade}

A prefeita da cidade tem tido participação nos fóruns de discussão dos Projetos. É defensora da idéia de que é necessário investir nas condições de vida urbana e priorizar projetos integrados que tenham como objetivo a construção da cidadania. No entanto, nos Projetos Comunidades Saudáveis não há um envolvimento de sua administração como um todo. A responsabilidade pela condução desses projetos da Prefeitura de Maceió está a cargo apenas da Secretaria Municipal da Saúde. A tabela 8 mostra como vem sendo referidas as responsabilidades entre os atores que assumem o comando do Projeto Comunidades Saudáveis:

Tabela 8 - Distribuição de responsabilidades referidas entre os atores que conduzem o Projeto

\begin{tabular}{|c|c|}
\hline Secretaria da Saúde & $\begin{array}{l}\text { - } \text { elaborar o Projeto } \\
\text { - } \text { conduzir o Projeto } \\
\text { - difundir os preceitos do Projeto } \\
\text { - } \text { sensibilizar os outros setores da administração pública } \\
\text { - } \text { realizar o acompanhamento de implementação }\end{array}$ \\
\hline Distrito de Saúde & $\begin{array}{l}\text { - elaborar o Projeto } \\
\text { - difundir os preceitos do Projeto } \\
\text { - definir ações junto `a comunidade }\end{array}$ \\
\hline Unidade de Saúde & $\begin{array}{l}\text { - } \text { elaborar o Projeto } \\
\text { - difundir os preceitos do Projeto } \\
\text { - definir ações junto à comunidade } \\
\text { - } \text { realizar os levantamentos iniciais }\end{array}$ \\
\hline
\end{tabular}

Inúmeras críticas têm sido formuladas em relação ao excessivo controle dos projetos Cidades Saudáveis pelo setor da saúde, já que são projetos que se delineiam desde sua concepção numa ação intersetorial (MENDES 1996; PAHO 1999). A experiência de Maceió mostra que pouco se tem avançado nesta direção. Três pontos podem ser destacados para entender tal participação: 
1) o próprio processo de descentralização na cidade, com a definição de regiões administrativas. A área da saúde é pioneira nesse processo, com as discussões do Sistema Único de Saúde, com a definição de Distritos Sanitários e a implementação do Controle Social por meio de Conselhos de Saúde;

2) a atuação da prefeita e ex-secretária da saúde, da atual secretária da saúde e de técnicos vinculada às questões da reforma no setor da saúde, tendo sido a prefeita ex-secretária da saúde, vereadora e líder sindical;

3) o compromisso de parcela do setor com projetos de melhoria de qualidade de vida e com a defesa da cidadania.

Destas experiências certamente resulta uma visão de que as questões de saúde são amplas e devem permear a administração como um todo.

Nesse sentido, há clareza para a Secretária de Saúde de que a solução para a continuidade dos Projetos Comunidades Saudáveis passa justamente por ampliar as discussões nos outros níveis de governo e criar condições facilitadoras para o trabalho intersetorial, já que a "saúde não se resolve só dentro da secretaria da saúde”. O envolvimento de outros setores da administração pública passa por uma estratégia de ampliar os debates e difundir os conceitos:

"Hoje a gente está discutindo um seminário de sensibilização, com o restante de nossos servidores e também com as outras secretarias da rede municipal. A Secretaria de Estado da Saúde também está provocando oficinas e facilita quando vamos buscar apoio, já que as pessoas já tem uma idéia do que é” (ES2).

\section{Os recursos, as parcerias e as alianças}

$\mathrm{O}$ fato de o governo do Estado agora ser do mesmo partido político da prefeitura tem sido apontado como uma possibilidade de encontrar uma solução para os problemas da cidade. Muitas das responsabilidades são ainda de competência do Estado, como o abastecimento de água, o saneamento básico, a escola de segundo grau, as grandes obras, etc.

Diz a prefeita: 
"Se você não tiver o Estado junto com o município, você não avança na construção da cidade saudável. Não adianta nós prefeitos sozinhos e nem secretários da saúde, fazermos uma cidade saudável se a gente não tem apoio do governo estadual e muito menos do governo federal ...".

Entretanto, esta parceria com o governo estadual não tem sido suficiente para resolver o problema dos escassos recursos do município. A dependência do município de repasses de verbas de outras esferas de governo acaba se configurando na principal dificuldade no atendimento de demandas, reduzindo o alcance da descentralização (JACOBI 1996).

Estes limites que afetam os projetos na área social, são impostos pela atual política econômica que privilegia as questões monetário-financeiras, metas de estabilidade e o ajuste fiscal, configurando a recentralização de recursos e estabelecimento de cortes nos gastos públicos por todas as esferas de governo (VIANA 1998).

Na tentativa de ampliar a participação dos cidadãos na gestão de políticas públicas, Maceió tem priorizado a aplicação de recursos por meio do Orçamento Cidadão, no qual são discutidas as prioridades das regiões através de assembléias com os delegados representantes das comunidades locais, mas, complementa a prefeita:

"Falta a participação do governo federal. Eu acho que a política ainda é muito de cima para baixo, o mais importante do governo federal é que ele participasse através de seus órgãos e representações para ver o que o povo quer, aí fazer seu planejamento global, porque o dinheiro do município, na sua maioria, não está em Maceió, nem no governo do Estado" (EP).

Como ressaltam SANTOS e WESTPHAL (1999), projetos estruturantes como os Cidades Saudáveis pressupõem ainda um forte protagonismo do Estado, pela natureza dos problemas de desenvolvimento e de infra-estrutura da maioria das cidades no país que necessitam ainda de muito investimento. A implantação de uma nova lógica de governar pelos governos municipais é um desafio. Centralizadas e 
setorizadas, as esferas de governo de todos os níveis não têm contribuído na descentralização de verbas, ao contrário disso, descentralizam-se apenas as responsabilidades locais.

A $4^{\mathrm{a}}$ Conferência Internacional sobre Promoção da Saúde realizada em Jakarta em 1997, recomenda que para se conseguir uma infra-estrutura para projetos de Promoção da Saúde, como o Projeto por Cidades Saudáveis, deve-se encontrar novos mecanismos para seu custeio, quer no âmbito local, quer no mundial. Para isso, é necessário criar incentivos para influenciar as ações de organizações governamentais, organizações não-governamentais e o setor privado, a fim de assegurar que a mobilização de recursos seja maximizada.

O caso Maceió, em que a falta de parceiros fora do setor governamental é um aspecto a ser considerado, nos remete à questão : seria possível ampliar a obtenção de recursos não governamentais, parcerias e alianças, garantindo pressupostos e estratégias que remetam a projetos que relacionem justiça social, eqüidade e qualidade de vida?

\section{Etapas do Projeto Comunidades Saudáveis em Maceió}

O detalhamento das etapas previstas para o desenvolvimento do Projeto Comunidades Saudáveis em Maceió podem ser observadas no organograma que se segue. Sumariamente, podem-se apreender três momentos principais:

- Momento 1: Investigação da realidade

- Momento 2: Construção de um acervo de conhecimento

- Momento 3: elaboração de proposta de Comunidade Saudável, com elaboração de projetos de intervenção (PMM 1996).

O exame do desenvolvimento desses momentos nas comunidades permite visualizar o alcance das proposições estabelecidas no projeto inicial definido pela Secretaria Municipal da Saúde de Maceió. 


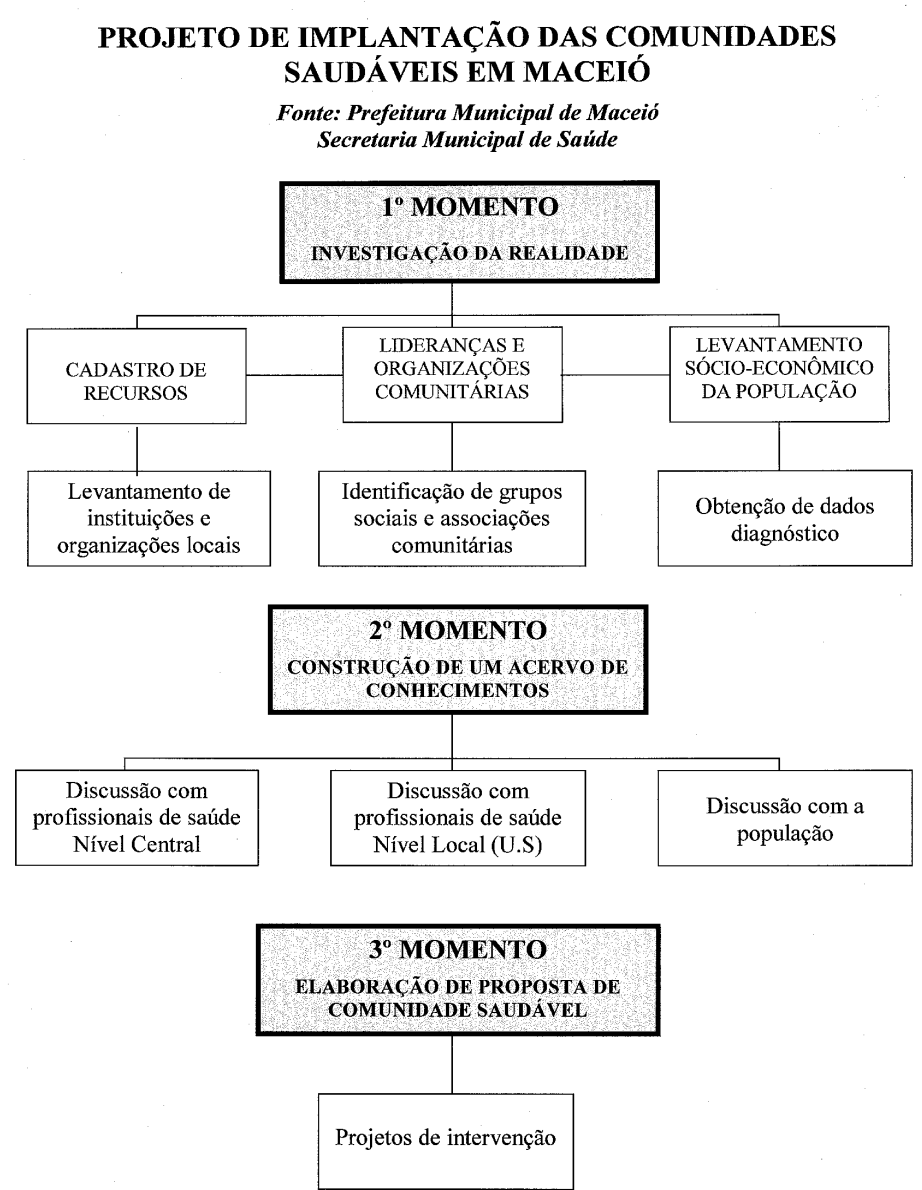

\section{O Projeto Comunidade SaUdável no Pontal da Barra}

\section{Caracterização da comunidade}

O Pontal da Barra situa-se na $2^{\mathrm{a}}$ região administrativa da cidade. Com uma população de 124.328 habitantes, esta região caracteriza-se pela concentração de parte do acervo cultural da cidade. Com mais de 200 anos de existência, o Pontal da Barra tem 2610 habitantes (IBGE 1997), e dista aproximadamente 6Km do centro de Maceió. É uma comunidade de pescadores localizada a sudoeste de Maceió, diante do canal do Calunga, que interliga a Lagoa Mundaú, antes de desembocar no mar. De acordo com registros históricos, desde 1792, o Pontal da Barra já existia com cerca de 30 edificações.

As principais atividades econômicas do local estão centradas no comércio, na pesca e no artesanato para fabricação de toalhas, redes e vestimentas. No entanto, como explica o membro da Associação dos Moradores, a pesca na Lagoa Mundaú, 
realizada de forma artesanal, é uma importante complementação no orçamento familiar (figuras 16 e 17).

"A maioria do pessoal hoje, a maioria aqui, eu acho que $20 \%$ da população trabalha, tem emprego mas mesmo assim, com o emprego a maioria ainda sobrevive da lagoa, quer dizer, eu não pesco, mas muita gente ainda pesca, quer dizer, tem emprego mas chega agora de noite $e$ vai pescar, um peixe, uma taioba, um siri, ajudando no orçamento.

Quer dizer, ele já consegue a comida, a mistura do almoço então já serve pra outras despesas, pra pagar aluguel duma casa, ou escola dos meninos, até pra fazer a feira mesmo. Mas todo o pessoal aqui, a maioria, $80 \%$ ainda sobrevive da lagoa, sempre tá tirando um complemento da lagoa” (EA1).
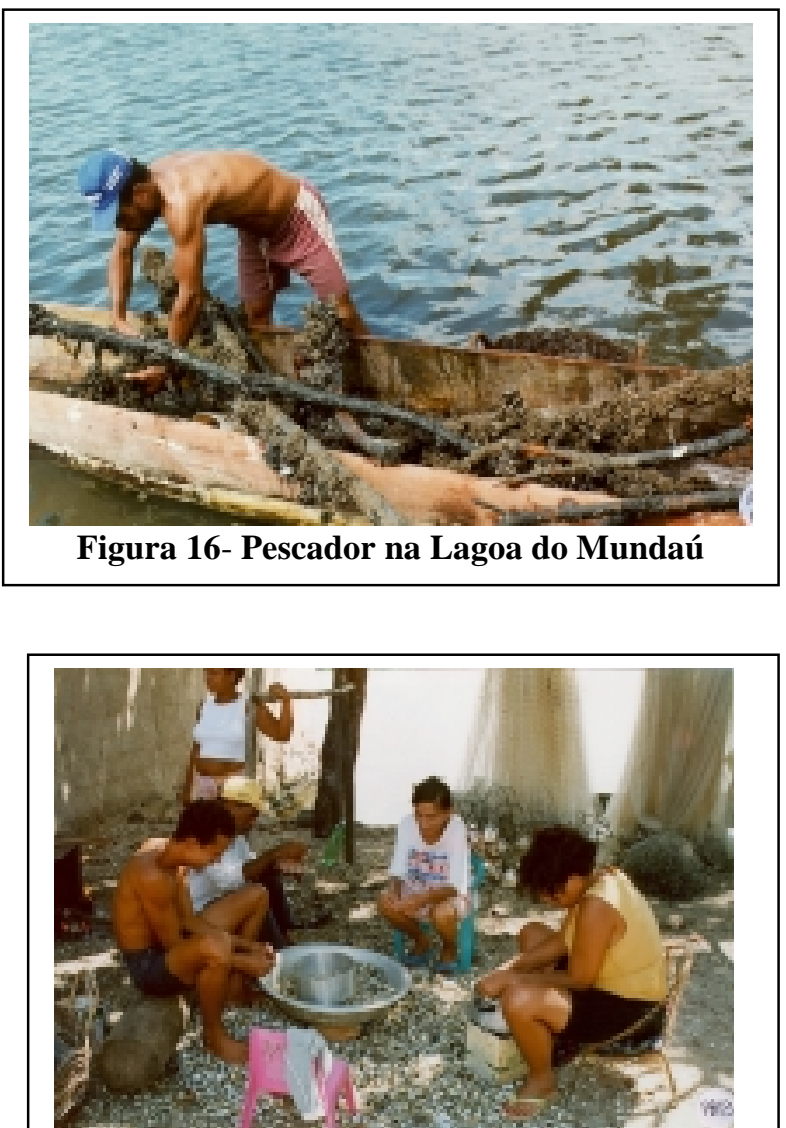

Figura 17- Marisqueiros/ Pontal da Barra

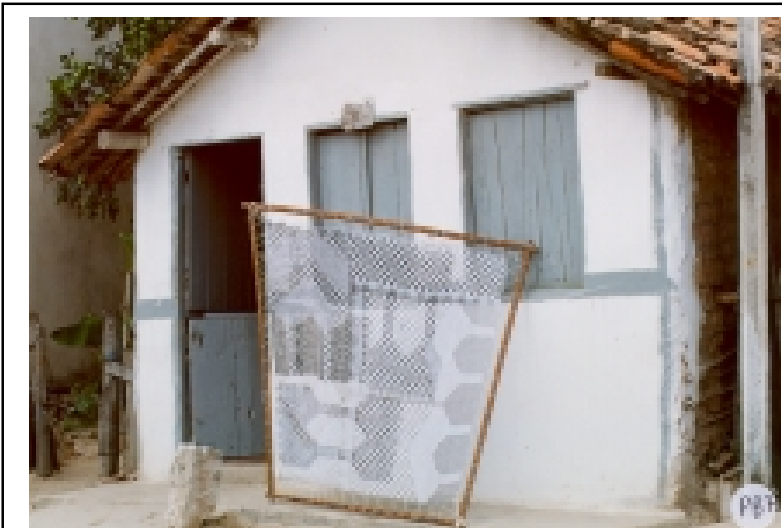

Figura 18- Artesanato - Filé no Pontal da Barra

A introdução do artesanato no local parece ter surgido como decorrência das atividades pesqueiras. $\mathrm{O}$ pescador fazia a rede e suas esposas passaram a tecer a rede, criando a arte do Filé. O artesanato hoje representa uma das importantes fontes de renda da população local (figura 18).

O desenvolvimento do turismo só seria alcançado na década de 70 , depois que o artesanato alagoano passou a ser divulgado para outros Estados do país e para outros países. O acesso mais fácil à localidade ocorreu somente em meados dos anos 
de 1960, quando se construiu uma rodovia que liga a Escola de Aprendizes de Marinheiros até o centro da cidade. Asfaltada, nos anos de 1970, após a implantação da Salgema, a estrada litorânea permitiu o acesso de turistas e o implemento do comércio local de artesanato. Atualmente as ruas do Pontal da Barra apresentam casas que expõem as peças do artesanato local e de outras localidades, além de inúmeros restaurantes típicos, que oferecem uma variedade de pratos regionais.

Instalada na área urbana de Maceió, a indústria química Salgema, hoje Trikem, (figura 19) passou a produzir cloro a partir de 1977. A sua localização próxima ao Pontal, numa região de ecossistemas de grande importância econômica e social, como a Lagoa do Mundaú, tem fomentado o debate em torno dos prejuízos culturais e ecológicos causados pela companhia.

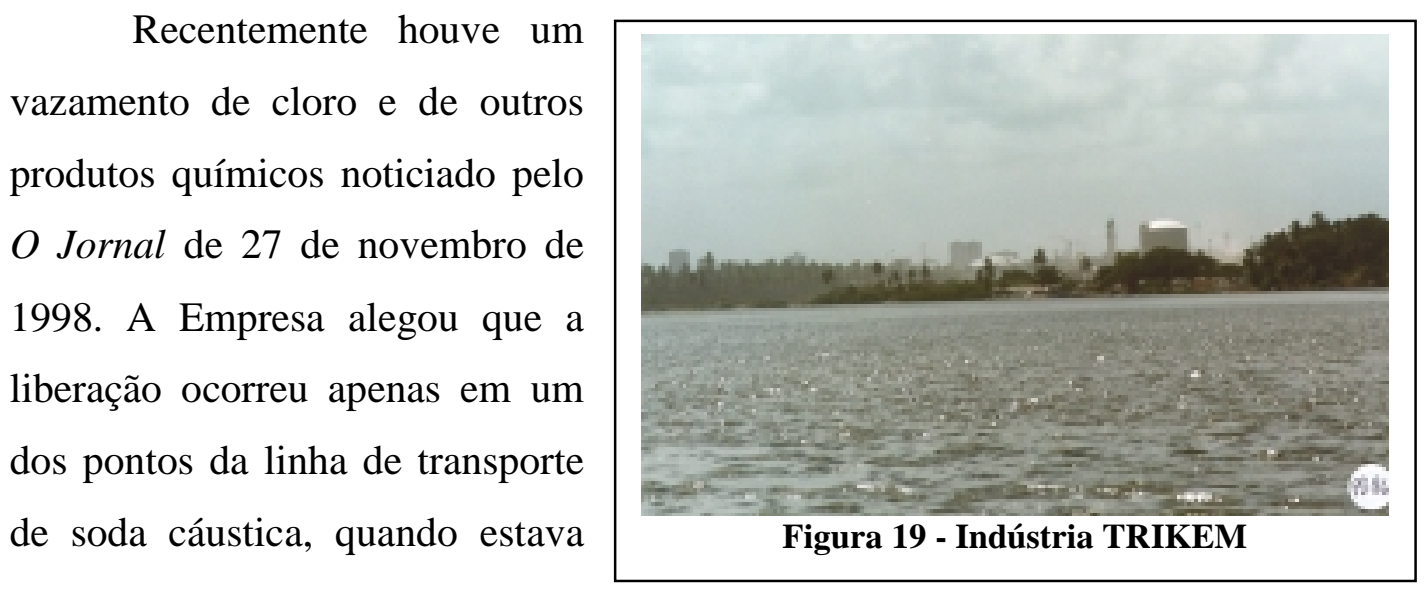
ocorrendo uma operação de manutenção. O superintendente da Trikem afirmou, ainda, que esta foi uma "ocorrência normal e que durou poucos segundos, não tendo maiores desdobramentos". Ainda assim, a Empresa promoveu uma simulação de acidentes que foi noticiada pelo mesmo jornal. Nesta simulação foi medido o tempo gasto de desocupação do entorno, tendo participado a comunidade do Pontal e cerca de 200 pessoas, entre médicos, bombeiros, PMs e guardas de trânsito. Isto não impediu que o Ministério Público instaurasse, naquele período, uma auditoria no parque industrial da Trikem para investigar as condições de funcionamento da companhia.

Apesar dos conflitos a Empresa tem investido em projetos no Pontal, especialmente em educação ambiental, como veremos mais adiante. 
Os dados que permitem caracterizar com maior profundidade a comunidade do Pontal, foram extraídos do Projeto Comunidade Saudável no Pontal da Barra realizado pela Secretaria Municipal de Saúde de Maceió. Esta primeira etapa, denominada de investigação da realidade, compreendeu a realização de um estudo, publicado em um documento intitulado Levantamento socioeconômico, epidemiológico e cultural da comunidade do Pontal da Barra de 1998. Reforçando a preocupação presente desde os primeiros esboços desta iniciativa com a construção coletiva do projeto, participação ativa de profissionais e comunidade esse relatório aponta os objetivos desta primeira etapa:

“...a produção desse diagnóstico possibilitará
o conhecimento do contexto geral, permitindo
que trabalhadores da saúde e comunidade
possam apreender a realidade e definir sua
prática com vistas à construção de projetos
coletivos de intervenção. Além disso, poderá
subsidiar e estimular o desenvolvimento da
consciência crítica dessa população em
relação aos problemas e seus
determinantes"(PMM 1998).

A partir de treinamento de profissionais de saúde, iniciou-se o reconhecimento da área, buscando identificar as principais instituições, associações do bairro, bem como realizar o mapeamento das ruas. É importante ressaltar a importância de se iniciar os Projetos por uma fase diagnóstica de levantamento de dados numa cidade onde a informação é muito difícil de ser obtida. Os dados resultantes deste levantamento puderam caracterizar a comunidade do Pontal da Barra de forma abrangente. Dentre os resultados obtidos entre 527 famílias estudadas, totalizando 2374 habitantes, podemos destacar algumas das conclusões que apresentam dados bastante significativos. Do total pesquisado $51,4 \%$ são do sexo feminino e $48,5 \%$ são do sexo masculino. No que diz respeito ao tempo de moradia no bairro observou-se um expressivo percentual de pessoas que residem há mais de 30 anos no bairro, $26,7 \%$, sendo que dessas $11,5 \%$, moram há mais de 46 anos no Pontal. 
O levantamento da renda familiar, tomando como parâmetro o salário mínimo do ano de 1998 ( $\mathrm{R} \$ 130,00)$, aponta que a maior parte das famílias tem renda entre 01 e 03 salários, representando $34,9 \%$, seguida de $26,5 \%$ de famílias com renda entre 04 e 06 salários mínimos.

A comunidade possui um sistema de saneamento e o abastecimento de água cobre $95,2 \%$ das casas. O grande problema da comunidade diz respeito à disposição de esgotos: $74 \%$ das famílias destinam seus dejetos em fossas, enquanto $22,9 \%$ escoam os dejetos a céu aberto em canais

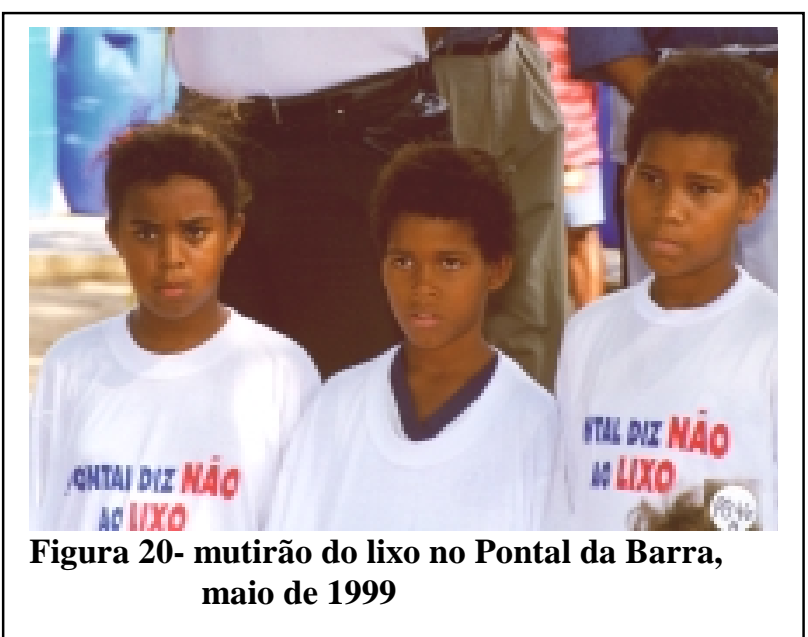
improvisados nas ruas, ou diretamente na Lagoa do Mundaú. Depoimentos coletados em reunião com as lideranças do bairro revelaram que o saneamento básico é a principal reivindicação da comunidade. O bairro dispõe de um sistema de coleta de lixo que abrange $88,8 \%$ dos domicílios pesquisados. A atuação do Gari Comunitário, programa desenvolvido pela Companhia de Coleta de Lixo do Município de Maceió, tem sido considerada fundamental na manutenção da limpeza do bairro. Não há dúvida de que o lixo tem sido uma preocupação da comunidade, que tem promovido através da escola local, juntamente com a Unidade de Saúde iniciativas que chamem a atenção da população em geral e das autoridades para o problema do lixo (figura

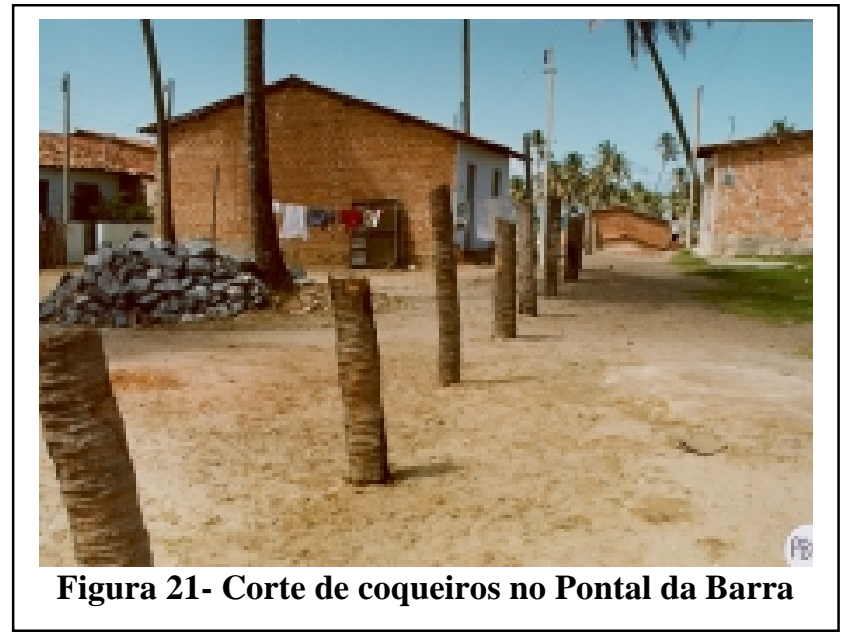

20).

Ainda de acordo com o levantamento da Secretaria de Saúde, as 527 famílias estudadas, $82,9 \%$, moram em casas de alvenaria e $10,0 \%$ em casas de taipa, sendo que a maioria $(75,3 \%)$ da população possui casa própria. A ocupação irregular das dunas agrava os problemas de infra-estrutura básica da comunidade. Há 
corte de coqueiros para construção de moradias, há improvisação de sanitários, os dejetos são lançados muitas vezes diretamente na areia e o lixo se acumula entre as casas (figuras 21 e 22).
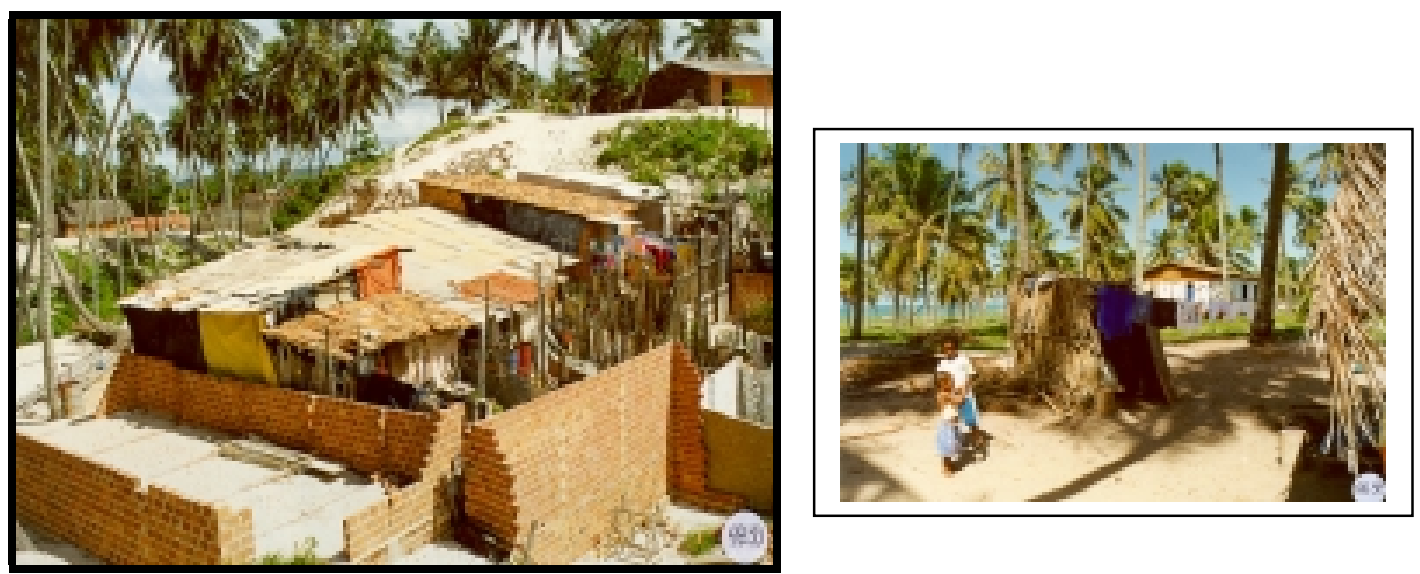

Figura 22- Ocupação de dunas no Pontal da Barra

Quanto à educação, o Pontal da Barra apresenta uma taxa de analfabetismo de $17,8 \%$, tendo sido considerada a população de 13 anos ou mais. O bairro possui uma escola pública de ensino fundamental, de $1^{\circ}$ grau, a escola Silvestre Péricles, que juntamente com outras escolas de Maceió participam do Projeto Lagoas e da construção de uma Agenda 21 para o município, que tem nesse momento uma prioridade, mobilização da comunidade em torno da luta por saneamento básico, conquista de áreas de lazer, defesa dos rios e da lagoa do Mundaú, valorização da memória popular e da cultura da criança:

"Nesses projetos, se desenvolve um sentido de cidadania, de participação, que muda a escola, cria uma nova forma de ensinar e aprender, fazendo ler e transformar o mundo, na esperança de que a cidade se entenda com a lagoa, em benefício da paz e da solidariedade com as atuais e futuras gerações” (PMM 1999).

A Unidade de Saúde Tarcísio Palmeira funciona com diversos programas e três equipes do Programa de Saúde da Família (PSF). Os principais problemas de saúde, de acordo com o PSF, dizem respeito a doenças infecto-contagiosas, como parasitoses, além de hipertensões, cefaléias, alcoolismo. A mortalidade infantil no ano de 1998 foi zero e até o mês de maio de 1999, uma criança com menos de um ano de idade morreu no bairro. 
Cidades Saudáveis no Brasil e os processos participativos: os casos de Jundiaí e Maceió

A unidade de saúde do Pontal faz também cobertura de saúde às ilhas que se localizam em frente ao bairro. Embora essas ilhas pertençam ao município vizinho de Marechal Deodoro, seus moradores buscam $\mathrm{O}$

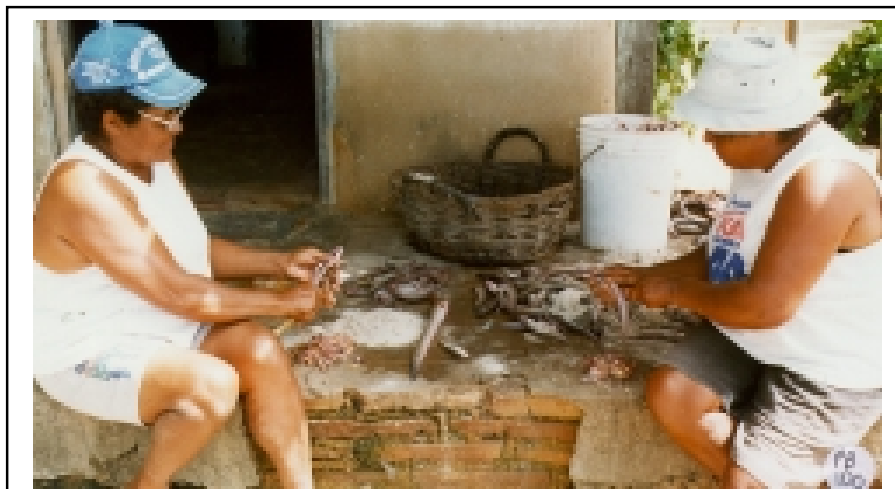

Figura 23- Pesca na Ilha Boca da Caixa na Lagoa do Mundaú atendimento no Pontal por ser mais próximo deles. São ilhas que não dispõem de infra-estrutura básica e seus moradores vivem da pesca artesanal na lagoa do Mundaú (figura 23).

\section{Histórico da Participação da população no Pontal da Barra}

Esta comunidade tem uma participação da sociedade civil bastante significativa na cidade. Como relata o Presidente da Associação dos Moradores essa participação tem uma história que foi construída ao longo dos anos:

“Antes aqui no Pontal, só existia mesmo era a Colônia de Pescadores, é a mais antiga, é de 1921, então ela é a primeira entidade representativa aqui do bairro. Com o tempo, com a chegada do padre Silvestre, foi criado $o$ Centro Social, que representava o bairro...mas o pessoal achava que era uma entidade fraca, então foi criada a Associação de Moradores, já com a chegada da Salgema... que ficou abrangendo as outras, é a Associação mais representativa do bairro, principalmente na parte política, é a representação mais conhecida oficialmente" (EA2).

Entretanto, surgiram novas formas de organização estimuladas pela igreja local, por instituições públicas, a exemplo de conselhos. Os números do levantamento realizado pela Secretaria da Saúde apontam que grande parte da população do Pontal participa de algum grupo social na comunidade, com predomínio do grupo religioso como mostra a tabela 9. 
Cidades Saudáveis no Brasil e os processos participativos: os casos de Jundiaí e Maceió

Tabela 9 - Participação em Grupos Sociais da Comunidade de Pontal da Barra

\begin{tabular}{|c|c|c|}
\hline Grupos sociais & Número de famílias & $\%$ \\
\hline Grupo religioso & 203 & 24,28 \\
\hline Associação & 120 & 14,35 \\
\hline Cooperativa & 8 & 0,96 \\
\hline Outros & 106 & 12,68 \\
\hline Não participa & 79 & 9,45 \\
\hline Não especificou & 320 & 38,28 \\
\hline total & 836 & 100,00 \\
\hline
\end{tabular}

Há, de fato, entre as pessoas do Pontal um forte sentimento comunitário e a certeza de que a prioridade é a luta por melhoria das condições de saneamento:

"Aqui todo mundo participa, a comunidade é politizada, todo mundo sabe o que quer”.

“... hoje a briga da gente aqui no bairro é o saneamento. Então todos nós fechamos, tanto pela associação, como os artesãos, a colônia. Eu acho que a necessidade básica hoje é saneamento, então a gente briga por esse direito" (EA2).

O fato da comunidade ser considerada participativa, que luta na direção de buscar soluções para encaminhar seus interesses comuns, e os dados mostrarem significativa inserção nos grupos sociais organizados, não impede que haja limitações e problemas, especialmente em relação à representatividade e à dificuldade de mobilizar a população para projetos coletivos. Embora o grupo representativo da comunidade seja atuante, é um grupo pequeno e tem tido dificuldades em repassar as informações até mesmo entre os associados das organizações locais. Assim, cada representante acaba expressando a sua opinião pessoal nas reuniões. Um bom exemplo para ilustrar este ponto foi a realização da reunião do Orçamento Cidadão no bairro, realizada em maio de 1999. Considerada um espaço importante de negociação entre a comunidade e o poder público na definição de prioridades locais, esta reunião contou com apenas 8 dos 200 associados do Centro Social. 
Apesar das dificuldades decorrentes de organização e participação, esse pequeno grupo foi se legitimando e sente que tem poder de decisão e que representa a comunidade e seus anseios.

Desde sua elaboração, o Projeto Comunidade Saudável teve como um de seus propulsores a idéia da participação social, com o fortalecimento das organizações locais e incentivo à ampliação da percepção da população com relação a seus problemas e necessidades. Apesar desses estabelecimentos iniciais poucas pessoas da sociedade civil organizada na comunidade têm clareza das premissas e das etapas previstas na consecução deste Projeto, mesmo aqueles representantes que dizem participar desde as primeiras reuniões.

Como o Projeto Comunidade Saudável no Pontal tem relação direta com o projeto da prefeitura de Revitalização do Bairro e seus objetivos se traduzem em melhoria de qualidade de vida para o bairro, é normal que sejam identificados por alguns grupos como uma iniciativa única, especialmente o grupo de técnicos responsáveis pela elaboração de projetos, que acabam tendo uma visão macro das políticas locais. O projeto de Revitalização começou a ser discutido anteriormente ao Projeto Comunidade Saudável como pode ser identificado em documentos obtidos junto à Prefeitura do Município de Maceió:

"Entenda-se revitalização como um conjunto
de ações, onde serão envolvidos vários
segmentos da estrutura administrativa
municipal, estadual, objetivando estabelecer
um processo de desenvolvimento integrado,
não só que se refere ao perfil
estético/arquitetônico, como também aos
aspectos de infra-estrutura urbana e
ambiental, indispensáveis para a gestão
otimizada do turismo, e ainda, proporcionar a
melhoria de qualidade de vida" (PMM s/d).

Tendo a perspectiva de ser um projeto que promovesse a integração entre as diferentes áreas do governo, o Projeto de Revitalização previa desde ações de saneamento básico, dragagem da Lagoa do Mundaú, até equipamentos urbanos, materiais para a restauração das fachadas das casa, revitalização cultural, entre outras. A comunidade tem uma crítica bastante contundente aos encaminhamentos deste Projeto: 
"O Projeto de Revitalização tá sendo uma farsa, cada secretaria tinha sim suas atribuições, que nenhuma cumpriu, quer dizer a saúde implantou a equipe de Saúde da Família ...”(GF2, em 28/05/1999).

Quando focalizamos, no entanto, o Projeto Comunidade Saudável nas discussões de grupo com a comunidade local, nota-se que se perde a amplitude de seu conceito e o entendimento de uma possível relação com o projeto de Revitalização do Pontal. São ilustrativas as falas extraídas da reunião do Grupo Focal a esse respeito. Ao responderem a pergunta o que é o Projeto Comunidade Saudável obtivemos as seguintes respostas:

Comunidade saudável é:

“...quando chega uma criança necessitando de internamento hospitalar e não tem vaga e nós enquanto conselheira requisitamos a vaga em qualquer hospital...”.

“... ter posto de saúde, é aquele que dá atendimento a todos os que pedem ..."

"É prevenir doenças, e ser um elo da comunidade e a Unidade de saúde”.

"É aquela que previne, é a questão do saneamento básico, é a questão do lixo, é a questão da educação ...” (GF2, em 28/05/1999).

Como o projeto tem condução da área da saúde e é identificado como sendo um projeto exclusivamente do setor, os técnicos e as associações e grupos comunitários têm uma visão de que este Projeto vai ser fortalecido através da consolidação do Conselho de Saúde, que vem se reunindo e se preparando para atuar:

"Quanto mais a gente participar das reuniões

(Do Conselho de Saúde) e reivindicar os nossos direitos, aí sim teremos uma Comunidade Saudável” (GF2, em 25/05/1999).

A equipe técnica de saúde, participante do Grupo Focal, sente dificuldades em conduzir projetos como este, de perspectiva intersetorial, que pressupõe um nível de negociação e articulação com os outros setores, que depende da iniciativa dos 
gestores, que nem sempre estão sensibilizados para tal. Essa equipe entende que seu papel nesse processo é promover essa sensibilização junto com a comunidade e de que esse papel é transitório, dado o potencial de autonomia para participar e reivindicar que a comunidade possui:

“... nós estamos aqui porque nós acreditamos
que vocês tem um potencial para levar isso
em frente, e vai haver um momento que o
técnico se retira da comunidade, e no
momento que o técnico for se retirando, então
a própria comunidade assume
completamente...” (GF2, em 28/05/1999)

\section{Dinâmica de interação e participação no Projeto Comunidades Saudáveis no Pontal da Barra}

Após a elaboração do Projeto Comunidades Saudáveis pela Secretaria da Saúde de Maceió, foram promovidas discussões com as equipes do Segundo Distrito de Saúde e a unidade de saúde do bairro do Pontal, que propiciaram reuniões com a comunidade local. A coordenadora do Distrito de Saúde relata que se inseriu no Projeto desde o início, acompanhando os encontros com a comunidade e a discussão dos problemas locais.

Coube, entretanto, à unidade de saúde o papel de mobilizar os grupos e associações para participar das discussões iniciais do Projeto Comunidades Saudáveis. Todos os segmentos comunitários foram convidados para as reuniões. As entrevistas com esses grupos apontam diversos participantes do Projeto, conforme ilustrada na figura 24 no Mapa de Integração e Participação, sendo que cada um deles expressa diferentemente suas motivações: a Associação dos Moradores e Amigos do Pontal da Barra participa porque se considera engajada em todos os projetos de melhoria do bairro, especialmente aqueles que envolvem as condições de vida das pessoas. O envolvimento é "uma forma de fiscalizar as ações do governo, porque nem sempre o que ele manda é bom para a comunidade”; a Colônia de Pescadores do Pontal da Barra participa porque quer ajudar no que for possível, em benefício da comunidade; a Associação dos Artesãos do Pontal da Barra participa porque acredita que é preciso melhorar a condição de vida, na prevenção das doenças, conscientizando as pessoas de que para ser saudável não significa apenas não ter doenças; a Associação dos Deficientes Físicos de Alagoas no Pontal participa 
porque quer ajudar o deficiente físico; o Centro Social Adalberto Leão Viana participa cedendo o espaço para reuniões; o representante do Conselho Tutelar dos Direitos da Criança e do Adolescente no Pontal participa porque entende que sem saúde não há nada; a Igreja Adventista acredita que em benefício da comunidade é necessário participar das discussões de melhora da saúde, ao invés de se restringir apenas ao religioso; o Grupo dos Idosos recebeu o convite da Unidade de Saúde e resolveu participar das reuniões.

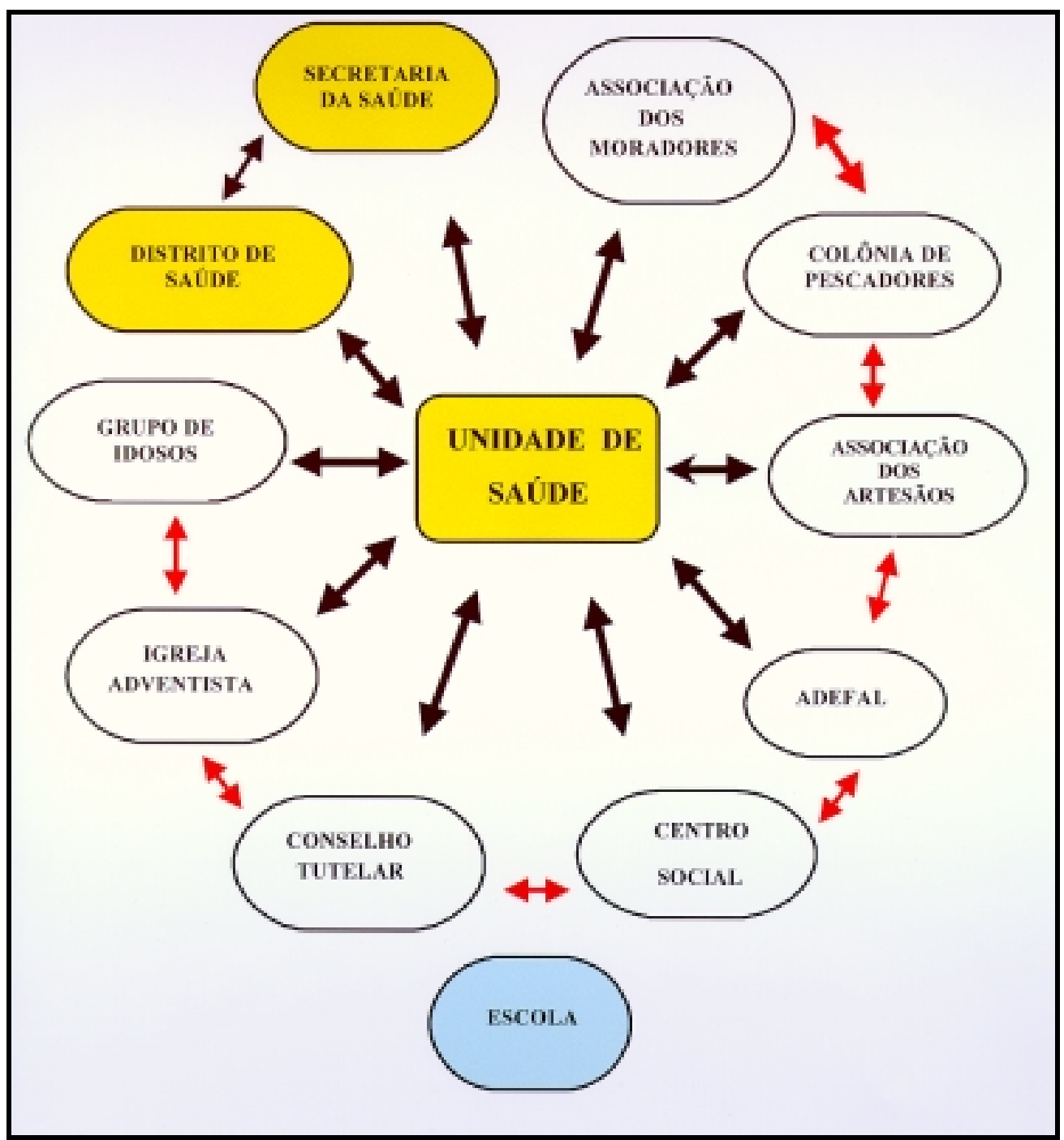

Figura 24 - Mapa de Interação e Participação no Projeto Comunidade Saudável no Pontal da Barra

A grande ausente deste processo é a escola local. A coordenadora pedagógica, vice-presidente da Associação dos Moradores e moradora antiga do bairro, considera-se participante representando a Associação, já que as professoras, segundo ela, nada sabem do projeto. No entanto, a direção da escola a considera também sua 
representante. Este descompasso acaba por gerar iniciativas paralelas que poderiam estar sendo desenvolvidas com um mesmo fim, a exemplo da Construção da Agenda 21 na escola, o Projeto Lagoas, de defesa da Lagoa do Mundaú. Isto não significa que não haja trabalhos sendo realizados conjuntamente entre a escola e a Unidade de Saúde, como o Mutirão da Limpeza,. realizado

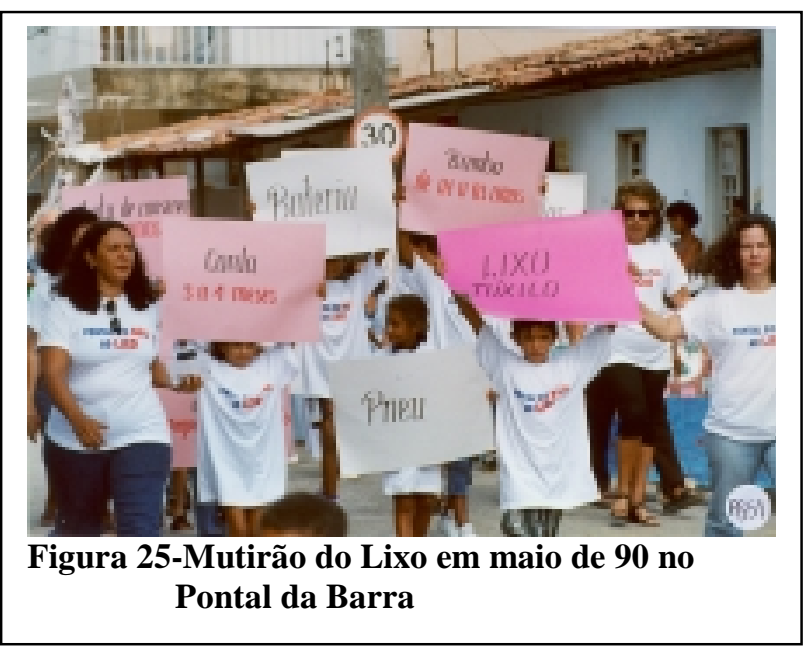
dia 25 de maio de 1999 (figura 25). Utilizando o slogan "Pontal diz não ao lixo", foi feita uma passeata no bairro onde eram carregados cartazes que enfatizavam a importância de se incentivar o turismo local por meio da manutenção da limpeza:

"Eu sou turista, vocês querem que eu volte? Mantenha o bairro limpo. Bairro sujo afasta turista”.

\section{Relação da comunidade com o poder público: conflitos e negociações}

A relação dos grupos sociais organizados da comunidade com o poder público é abordada com base em suas múltiplas dimensões. Por um lado, há crédito nas linhas de ação da prefeitura, tendo sido enfatizados o Gari Comunitário, o Programa de Saúde da Família, a qualidade do ensino público. Há também um relacionamento amigável com a prefeita, reconhecida pelas suas lutas conjuntas com a comunidade:

\footnotetext{
"Ela abriu um espaço muito grande na comunidade, ela gosta muito do Pontal, ela defendeu muito a gente na briga com a Salgema... ...então ela assumiu e trouxe todos os canais de comunicação para cá, o secretariado a disposição. ...dos políticos que passaram aí é a única que a gente está tendo a chance de se comunicar com ela" (GF2, em 28/05/1999).
} 
Por outro lado, há frustrações em face das ações ou omissão do poder público nos seus diversos níveis, o que acaba contribuindo, de acordo com os entrevistados, para o descrédito da luta das associações locais:

"A gente fechou as prioridades. Agora só falta começar a executar as coisas. Se o projeto de revitalização saísse, como a gente quer, era uma conquista” (GF2, em 28/05/1999).

“...nós temos uma ambulância, tá com 10 anos, mas é uma ambulância. Essa ambulância precisou trocar a bateria, o pneu. Precisa de um motorista...uma ambulância parada só porque a prefeitura não quer pagar um motorista..." (GF2, em 28/05/1999).

“... pra fazer parceria com o poder público? Parece que quanto mais a gente ajuda, mais ele se afasta" (GF2, em 28/05/1999).

Em relação à forma de encaminhamentos das demandas, existe a certeza de que a população sabe o que quer, mas permanece a dúvida de que estas serão consideradas pela Prefeitura Municipal. Ainda assim há preocupação de se estabelecer uma postura de negociação política, pautada na cooperação:

"A gente faz tudo pra num momento de crise para não estar cobrando só do poder público, a gente tenta fazer a nossa parte. A gente cobra, mas a gente faz a nossa parte" (GF2, em 28/05/1999).

Em suma, os representantes de grupos sociais organizados no Pontal da Barra descrevem duas dificuldades encontradas, tanto no desenvolvimento de projetos como o Comunidade Saudável, quanto outros que visem à melhoria de qualidade de vida da população local. Em primeiro lugar, as críticas são direcionadas ao poder público. Criticam a lentidão do poder público no encaminhamento e resolução dos problemas, criticam também a omissão dos órgãos públicos e concluem que falta vontade política ao executivo em encaminhá-lo. Em segundo lugar, as críticas referem-se à própria comunidade, que participa pouco e é pouco politizada:

"A comunidade tem que saber votar e se não der certo a gente tira ... se o povo se organizasse mais conseguiríamos muita coisa. o povo unido tira qualquer pessoa, ele unido 
Cidades Saudáveis no Brasil e os processos participativos: os casos de Jundiaí e Maceió

vence qualquer barreira" (GF2, em

28/05/1999).

\section{Parceria com a Empresa}

Os depoimentos colhidos com os representantes das organizações comunitárias apontam a complexidade da relação que se estabelece com a Empresa Trikem, ex Salgema, localizada à beira da lagoa Mundaú, muito próxima à comunidade do Pontal. Alguns representantes fazem uma referência negativa e crítica à Empresa:

“... é uma indústria química muito poderosa, e muito perigosa. A gente está morando do lado de um vulcão, pior que Xernobil ..." (GF2, em 28/05/1999).

Funcionário da Empresa e líder comunitário expressa a dificuldade de sua posição quando era presidente do Centro Social local. A população criticava exigindo que ele tivesse uma ação mais dura com Empresa:

"Eu não podia, eu trabalhava na Empresa.

Foi quando foi criada a Associação dos moradores, prá combater mais ...Eles queriam fechar a Empresa. Qual foi meu papel? Foi papel de intermediário, eu não ia contra a comunidade, porque nasci aqui no bairro, minha família toda é daqui, também não queria trair minha família, então decisão nenhuma eu podia tomar, quem tem que tomar é a comunidade" (EA2).

O morador e funcionário acredita que:

“... a gente só tinha dois caminhos, ou saía, ou convivia. Vamos tentar conviver, eu acho que é a melhor maneira porque o mundo é industrializado. Tá certo que não deveria ser implantada, mas aí está o investimento. Não sai porque o custo é muito alto. Vamos exigir segurança e melhorar a condição de vida da gente...” (EA2).

$\mathrm{Na}$ crença de que a convivência com a Empresa seria o caminho, o líder comunitário exerceu o papel de intermediário, que consistia em ir a casa das pessoas discutir a situação, levar as pessoas à Empresa, ou trazer algum diretor da Empresa 
nas casas, promovendo o diálogo, que até aquele momento não estava se dando. Nos últimos três anos, segundo ele, a mudança de gerenciamento na Empresa, agora da Organização Odebrecht, alterou a relação da Empresa com o bairro, modificando sua comunicação com a comunidade, promovendo visitas coordenadas a grupos da comunidade, mostrando seus mecanismos de segurança, promovendo treinamentos simulados com a comunidade, e principalmente investindo em projetos de educação ambiental.

Apesar das críticas e da discordância da implantação da Empresa próximo a localidade, é certo que a parceria tem se realizado. A Empresa tem apoiado projetos de Educação Ambiental, a exemplo da publicação Agenda 21 das Escolas Municipais de Maceió, e tem investido em reforma e na compra de computadores para a escola Silvestre Péricles.

\section{O Projeto Comunidade SaUdÁvel em CruZ das Almas: COMUNidAdeS Grotas do ARroZ E do SÃo RAFAEL E LoteAMENTo SANTO ONOFRE}

\section{Caracterização das comunidades}

As comunidades Grotas do Arroz e do São Rafael, e Loteamento Santo Onofre localizam-se entre dois bairros na cidade de Maceió: Cruz das Almas, que pertence à $1^{\mathrm{a}}$ região administrativa, que possui 118.812 habitantes, e Jacintinho, da $5^{\mathrm{a}}$ região administrativa, que conta com 129.201 habitantes. A $1^{a}$ região possui bairros tradicionais como o Jaraguá, bairro que até a metade do século XIX concentrava residências de famílias tradicionais. Com a instalação do cais do Porto na década de 40, o bairro perde sua característica residencial e se torna basicamente comercial. A $5^{\mathrm{a}}$ região caracteriza-se por ser uma região comercial.

De acordo com os dados do IBGE 1991 e 1996, o bairro de Cruz das Almas foi um dos que apresentou maior crescimento no período, 18.702 habitantes em 1991 e 25.870 habitantes em 1996, representando um percentual de crescimento de 38,3\%. Já o Jacintinho é o bairro mais populoso apresentando em 1996, de acordo com o IBGE 80.840 habitantes.

Nos últimos anos, a população vai deixando o campo e buscando formas de sobrevivência na cidade, ocupando áreas de difícil acesso entre morros e grotas, onde possam construir suas moradias. Essa ocupação desordenada que vem se dando na 
Cidades Saudáveis no Brasil e os processos participativos: os casos de Jundiaí e Maceió

área periférica da cidade, constitui as localidades denominadas Grota do Arroz, Grota do São Rafael e Loteamento Santo Onofre (figura 26).

Essas comunidades possuem uma população de cerca de 5.000 habitantes. As Grotas apresentam relevo irregular que dificulta o deslocamento da população. Apresentam um cenário de pobreza e desigualdades sociais bastante acentuadas. A exclusão a que a população está submetida é ressaltada pelo vice-presidente da Associação de Moradores:

“... a nossa situação é tão delicada que nós não fazemos parte nem do mapa de Maceió, nós somos excluídos até nisso ..." (GF3, em 02/06/1999).

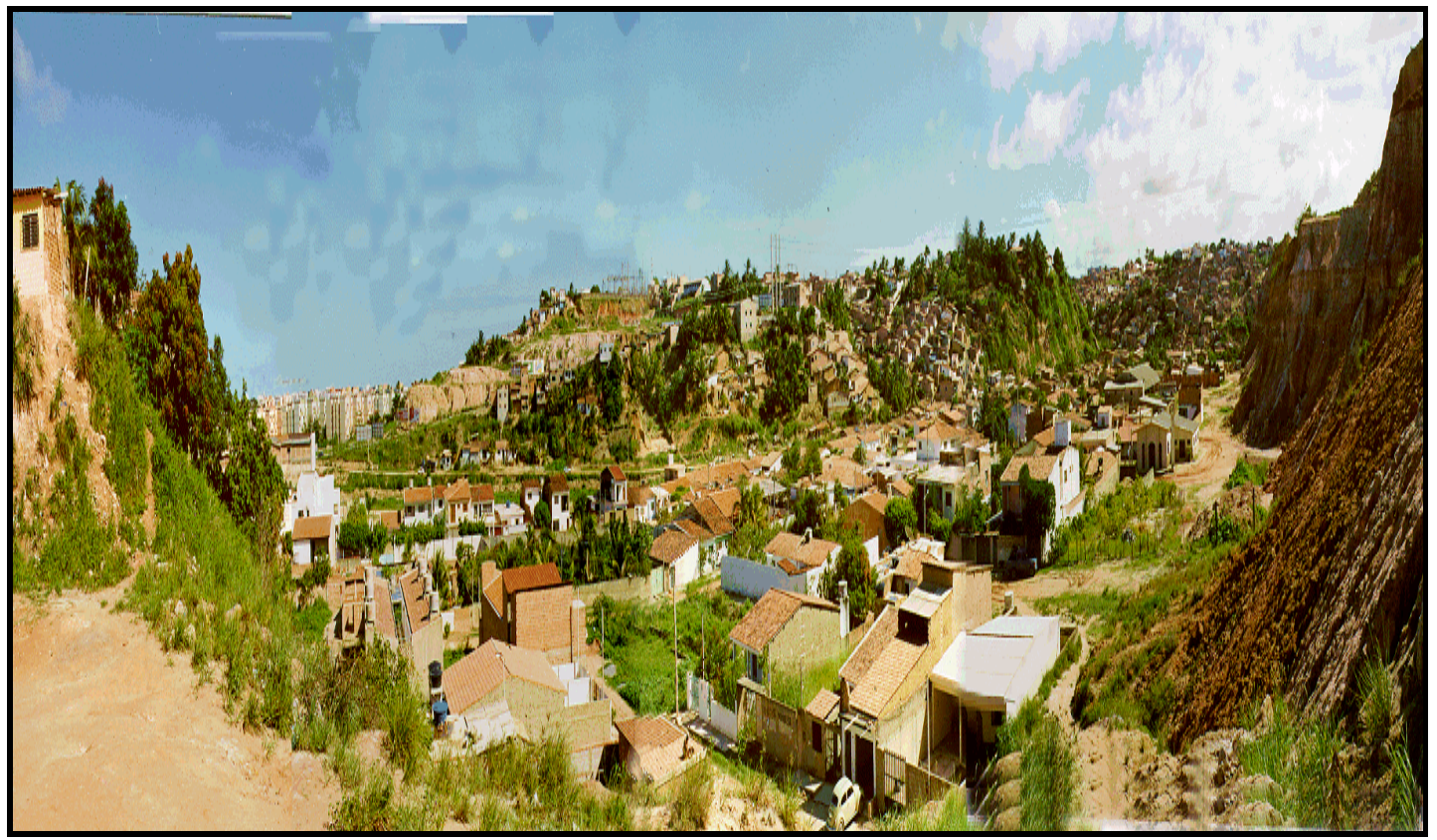

Figura 26- Grota do São Rafael

A precariedade das comunidades, o baixo poder aquisitivo de sua população localizada em uma área geograficamente bem delimitada, com características comuns, incentivaram a Secretaria Municipal de Saúde a investir no Projeto Comunidade Saudável. Foi a primeira experiência da cidade. A partir de agosto de 1996, iniciaram-se as primeiras reuniões de profissionais da saúde com as lideranças locais para iniciar o desenvolvimento do Projeto Comunidade Saudável nessa região. O ponto de partida foi a leitura do documento básico, redigido pela Secretaria Municipal de Saúde de Maceió. Em seguida, de acordo com as diretrizes estabelecidas, iniciou-se a etapa de levantamento de dados, com o objetivo de traçar 
o perfil da comunidade. O treinamento executado pela Secretaria de Saúde permitiu que agentes comunitários do Programa de Saúde da Família e educadores de saúde realizassem os trabalhos de coleta em 1044 famílias nas 3 localidades selecionadas (PMM s/d).

Dos dados obtidos, podemos selecionar alguns que caracterizam a região e podem contribuir significativamente no desenvolvimento de projetos de melhoria de vida nas localidades. Do total pesquisado, $79,8 \%$ possuem casa própria e a maioria tem tempo de moradia de no máximo 5 anos, representando $72,2 \%$ do total. A maioria das casas é de alvenaria, 68,6\%. As famílias moram de forma precária e a ocupação dos morros para a construção das casas foi sendo realizada de forma irregular e imprópria, trazendo riscos ambientais à região, e especialmente colocando em risco a vida de milhares de pessoas das comunidades

Apesar de boa parte da população possuir água encanada, $65 \%$, sua ligação é realizada clandestinamente, já que não há infra-estrutura adequada para seu fornecimento. Um percentual elevado de famílias, 29,8\%, utiliza-se de poço artesiano.

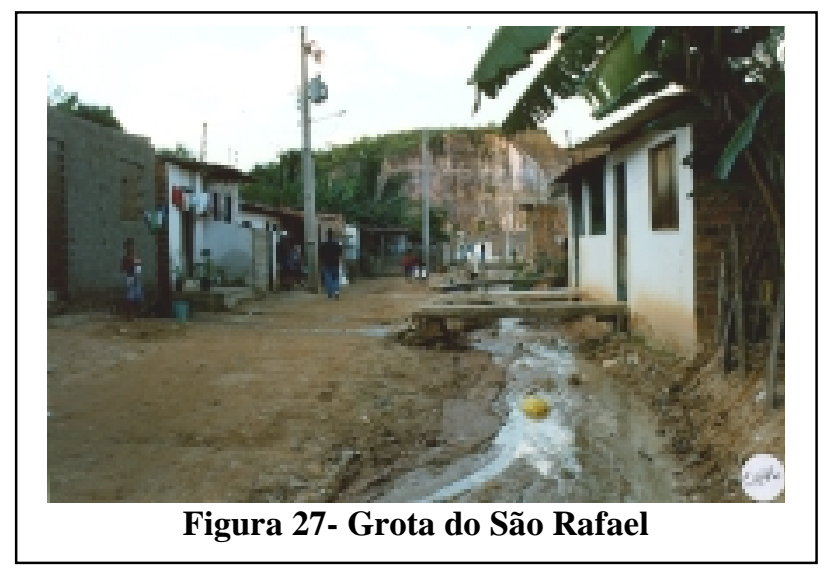

Quanto ao destino dos dejetos, a maioria das famílias pesquisadas utiliza-se de fossas sépticas, $87 \%$, enquanto que $11 \%$ despejam seus dejetos diretamente no solo. Devido à declividade do solo, os dejetos escorrem a céu aberto pelas ruas e vielas, penetram nas casas e alcançam as ruas principais (figura 27).

O bairro sem saneamento básico se converte num foco de doenças. O lixo é um dos mais graves problemas. Apenas $22,2 \%$ das famílias tem seu lixo recolhido regularmente e $36,6 \%$ das famílias despejam o lixo a céu aberto. O acúmulo de lixo nas ruas sem asfalto contribui para os problemas da população. 
Os problemas tornam-se ainda mais graves na época de chuvas, porque o acesso às casas que se localizam no alto dos morros é realizado por escadarias construídas pelos próprios moradores. Alguns são obrigados a deixar suas casas quando chove, já que suas moradias são tomadas pelas águas das chuvas (figura 28).

Ainda de acordo com o levantamento da Secretaria da Saúde, $57,3 \%$ da população local possui energia elétrica, sendo que grande parte, $38,6 \%$ adquire

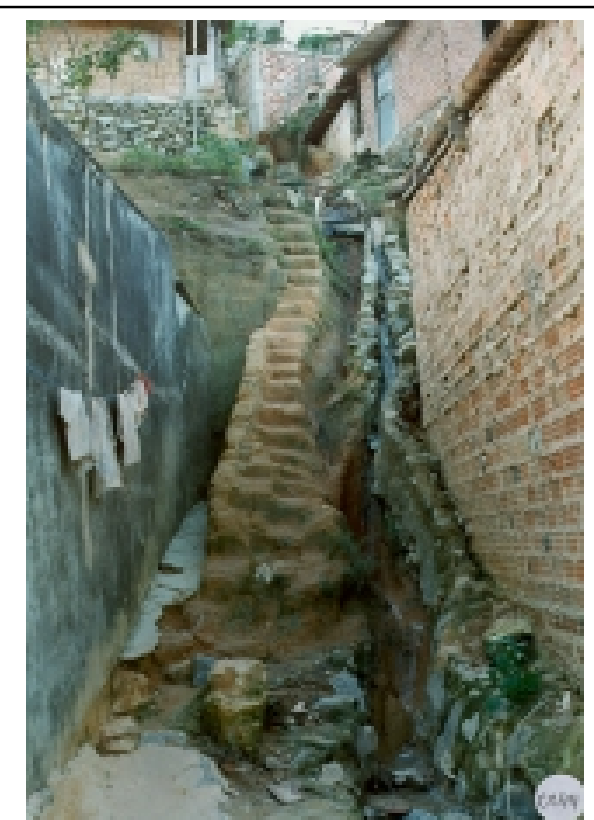

Figura 28- Escadarias da Grota do São Rafael energia clandestinamente.

O único equipamentos público do local é o Posto de Saúde São Francisco de Paula, que funciona com diversos programas de saúde e equipes do Programa de Saúde da Família.

\section{Histórico da Participação da população das comunidades Grota do Arroz, Grota do São Rafael e Loteamento Santo Onofre}

JACOBI (1996), em seus estudos já indica que grupos de menor poder aquisitivo, localizados em regiões com menor qualidade de vida, e que são afetados por problemas de sobrevivência com maior intensidade, não apresentam necessariamente maior mobilização comunitária. É o que ocorre nessas comunidades. A maior parte da população participa muito pouco dos movimentos e associações de bairro (tabela 10).

O levantamento realizado em 1997, de acordo com a tabela acima, apontou a existência de uma associação de moradores nesses bairros: a Associação São Francisco de Paula, que existe há cerca de 12 anos e abrange especialmente a comunidade da Grota do Arroz. Esta associação, entretanto, tem sido marcada muito mais pelo fortalecimento político de seu presidente, do que pela mobilização da população por lutas coletivas. A atuação da associação é muito incipiente e não tem 
promovido reuniões entre os associados. Há muitos anos não ocorre mudança na diretoria que é formada quase exclusivamente por uma família.

Tabela 10 - Participação em Grupos Sociais das Comunidades

\begin{tabular}{|l|c|c|}
\hline Grupos sociais & Número de famílias & \% \\
\hline Grupo religioso & 402 & 38,5 \\
\hline Associação & 14 & 1,34 \\
\hline Não especificou & 150 & 14,37 \\
\hline Não participam & 478 & 45,78 \\
\hline Total & 1044 & 100,00 \\
\hline
\end{tabular}

Em 1998, outra associação foi criada, com base nas Comunidades de São Rafael e de Santo Onofre, a Associação do São Rafael e do loteamento Santo Onofre, ASCONOEL, que procura se estruturar para encaminhar as reivindicações da população que habita essas regiões precariamente urbanizadas. Os depoimentos de seu presidente e do vice-presidente explicam como surgiu a ASCONOEL:

“... quando foi um dia deu algo na cabeça de inventar uma associação, eu cheguei, conversei com os moradores. Ali na Grota do Arroz tinha posto, tinha ônibus, telefone e nós não tinha, e a nossa Grota era bem maior...quatro ou cinco moradores se uniu, a Igreja Nossa Senhora das Dores..." (GF3, em 02/06/1999).

“... eu tinha feito uma promessa, de não me envolver mais com a comunidade, as pessoas cobram muito da gente, às vezes a gente fica angustiado, porque mesmo com toda a vontade do mundo, você não tem o poder de decidir, a não ser o poder de pressão, de reivindicar ..., como você vê tanta coisa errada, vê tanta exclusão,, vê tanta necessidade, não tem como ficar fora, e nós acabamos nos envolvendo e nos juntamos com o Seu Antônio e junto com ele fizemos uma associação que não existia" (GF3, em 02/06/1999). 
O presidente representa a Grota do Rafael, e o vice-presidente o Loteamento Santo Onofre. Esta foi uma forma encontrada pelos moradores de se dividirem para reivindicar melhorias para as comunidades em instâncias junto ao governo. Como essas comunidades estão localizadas entre os bairros Jacintinho e Cruz das Almas, e o Orçamento Cidadão é discutido nesses dois bairros separadamente. Estrategicamente um dos representantes participa nas reuniões do Jacintinho e outro nas reuniões de Cruz das Almas.

Dada a constatação de que a maioria dos entrevistados pouco se mobiliza, o Projeto Comunidades Saudáveis previa o desenvolvimento de ações de capacitação de lideranças formais e espontâneas, que tivessem representatividade perante a comunidade e pudessem estimular a participação da população na resolução dos problemas (PMM s/d). De fato, a própria criação da ASCONOEL, foi fortalecida por técnicos da unidade de saúde local

A iniciativa de implantar o Projeto Comunidade Saudável nessas comunidades foi marcada por momentos difíceis, de acordo com depoimento dos moradores. As pessoas da comunidade representantes dos grupos sociais organizados, não sabem relatar seu início. Para alguns, o levantamento inicial do diagnóstico significou apenas um trabalho de pesquisa com a equipe do órgão público. Outros referem-se aos trabalhos iniciais como conturbados, em que diversos técnicos da Secretaria Municipal da Saúde tentam explicar os objetivos do projeto, mas:

“O povo não queria assistir ...o pessoal já está descrente das coisas aqui da cidade...já veio tantos órgãos governamentais, já veio tantas coisas por aqui, a gente já sonhou" (GF3, em 02/06/1999).

No entanto, as dificuldade iniciais não estão restritas à população. O processo inicial foi difícil também para os técnicos da Secretaria de Saúde. Um dos componentes do grupo responsável pelos levantamentos iniciais, elaboração dos questionários, análise dos dados, sentia-se também com poucas informações sobre o Projeto e suas diretrizes: 
“... eu comecei a me questionar e procurar textos e ler e fui me inserindo no projeto desta maneira..." (GF3, em 02/06/1999).

Outros relatam a dificuldade encontrada pelo grupo no trabalho de pesquisa, desde a elaboração dos questionários, na tabulação dos dados, na síntese final:

“... as perguntas que tinham resposta que não tinham nada a ver com aquela pergunta, a pessoa não estava sabendo responder, então teve falhas, faltaram dados, até foi difícil na interpretação desses dados..." (GF3, em 02/06/1999).

A primeira etapa do Projeto, que consistiu desde o levantamento de dados até a socialização dos dados junto a comunidade é referido por todos como um fase de grande mobilização nas comunidades. Houve reuniões com todos os níveis da Secretaria da Saúde, com os profissionais de saúde da Unidade de Saúde, e com a comunidade. A etapa seguinte prevista, de envolvimento de outros setores do governo na definição de prioridades, no entanto, caminha muito lentamente.

\section{Dinâmica de interação entre os participantes do Projeto Comunidade Saudável nas Grotas do Arroz, São Rafael e Loteamento Santo Onofre}

A representação do Mapa de Integração e Participação (figura 29) do Projeto Comunidade Saudável nas Grotas do Arroz, do São Rafael e no Loteamento Santo Onofre permite visualizar que os principais envolvidos estão no setor público de saúde, que criaram canais de participação para que as associações locais pudessem expressar suas reivindicações. O incentivo dado pela Secretária da Saúde é, no entender do presidente da Associação dos Moradores, a principal motivação à participação no Projeto. O Grupo de Jovens presente nas primeiras atividades envolveu-se por acreditar que o projeto traria benefícios à comunidade, no entanto, seu representante deixou de participar alegando falta de tempo, já que estuda e trabalha. A ASCONOEL foi sendo estruturada no decorrer das discussões do Projeto. Uma de suas associadas entende que a participação no Projeto trouxe a possibilidade de conhecimento de direitos que desconheciam.

Houve alteração na participação da equipe técnica do Posto de Saúde. As técnicas que haviam conduzido todo o processo de sensibilização inicial e que respondiam pela coordenação do projeto local, deixaram de trabalhar na unidade de 
saúde local. A saída dessas técnicas significou, na visão de alguns, um prejuízo na continuidade do Projeto Comunidade Saudável nesses bairros, para outros, as mudanças administrativas não acarretaram problemas de continuidade, uma vez que as idéias centrais puderam ser mantidas. Os motivos que cercam a saída dessas técnicas não ficaram bem esclarecidos. Uma das entrevistadas relata que o afastamento deveu-se a motivos políticos.

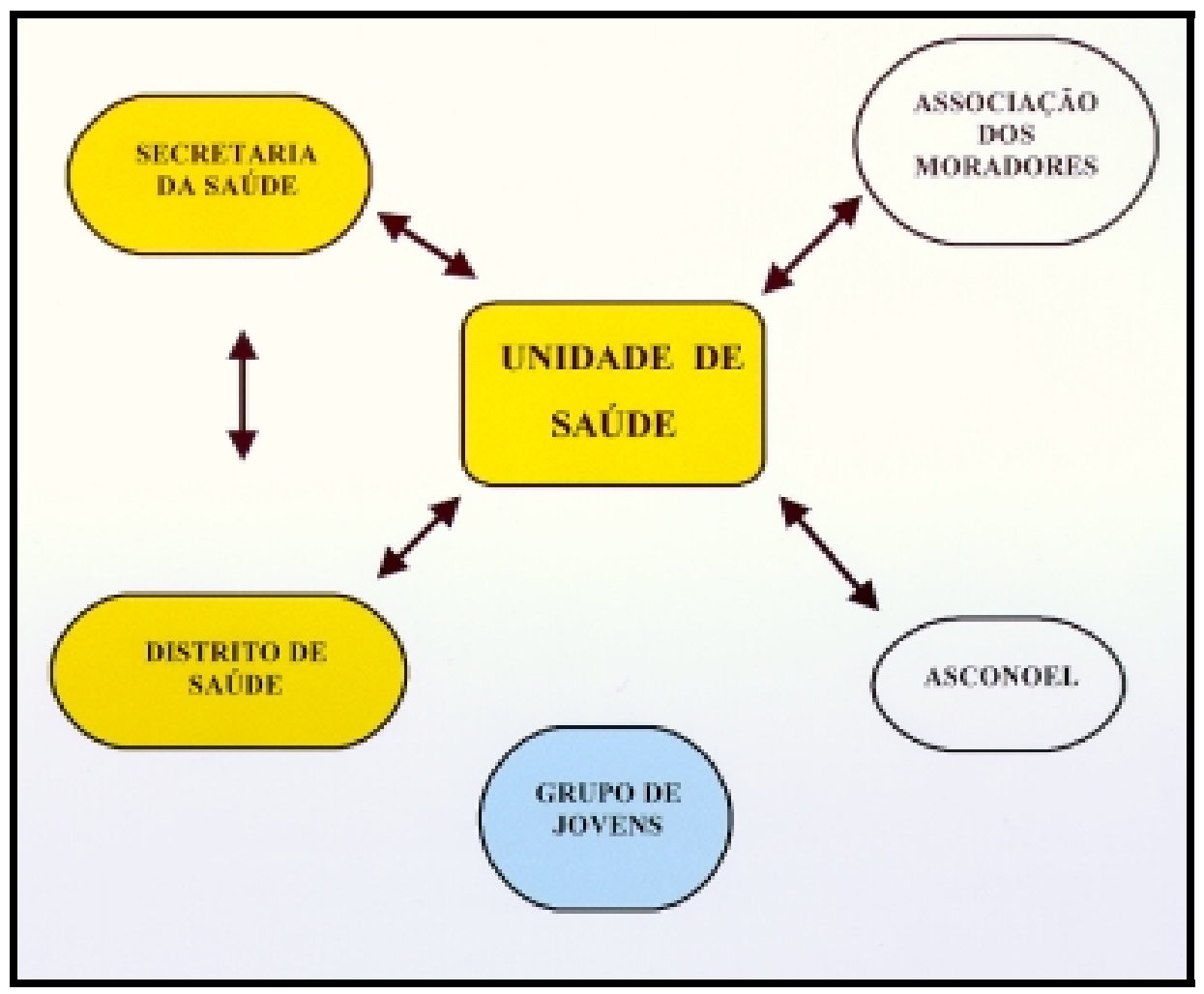

Figura 29:Mapa de Interação e Participação do Projeto Comunidade Saudável nas Grotas do Arroz, do São Rafael e Loteamento Santo Onofre

\section{Relação da comunidade com o poder público}

A descrença no poder público é fortemente presente nos discursos dos moradores. A avaliação quanto ao encaminhamento e atendimento das demandas é de que estas foram muito discutidas, mas nem sempre atendidas, o que acaba por gerar descrédito da população que já participa pouco e tem freqüentemente uma atitude passiva diante dos problemas:

“...nós vamos para as reuniões, então tal dia vai ser cavado o poço, nós chegamos para o povo e dizemos... mas aí faz 1 mês, dois meses, 3, 4 meses e isso não acontece, então 
na próxima reunião o pessoal não vai” (GF3, em 02/06/1999).

É constante a referência negativa à postura do governo municipal que iniciou o Comunidade Saudável, estimulou a participação da comunidade, vestiu a camisa do Projeto, mas as pessoas esperavam um empenho maior do poder público. Ainda assim, há unanimidade de que algumas demandas importantes foram encaminhadas: a implementação do Gari Comunitário de coleta do lixo, o Programa de Saúde da Família, que conta com 3 equipes, a construção de escadarias, a ampliação da iluminação pública.

O encaminhamento de demandas se dá por meio da participação das associações no Orçamento Cidadão. Este processo requer uma dinâmica de diálogo e negociação permanentes, e seus resultados nem sempre atendem às expectativas dos representantes da população. Os problemas são elencados pela comunidade que elege suas prioridades. A prioridade dessas localidades é pela construção de uma escola. No entanto, os estudos da prefeitura concluíram que o bairro Cruz das Almas já possui uma escola que pode atender essas comunidades. Indignado, o vice-presidente da ASCONOEL lembra que a escola fica localizada do outro lado da estrada, e que a quantidade de crianças dos bairros já seria suficiente para a implantação de uma escola no local, ele relata:

“... a gente diz que esqueceu de tudo, de
saneamento, de água, de luz, de tudo. Escola
aí, disseram, não pode, porque do outro lado
da pista já tem escola do município. Aí você
faz o que meu Deus. Aí disseram, não tem
como não fazer escola não, digam outra
prioridade. Tudo bem escadarias para o
povo, pelo menos não escorregam na lama. Aí
fomos contemplados com 3 escadarias, que
até agora não foram feitas...” (GF3, em
02/06/1999).

Iniciativas como as do Orçamento Cidadão que têm se dado no âmbito do poder local, e buscam co-responsabilidade entre Estado e sociedade na definição e na partilha das decisões, correm riscos de se tornarem meras retóricas e reproduzir os mesmos vícios e limitações da política tradicional. Por isso, essas experiências devem instituir regras, bem como critérios que permitam pontuar os interesses numa 
escala de prioridades, que permitam ampliar as possibilidades de equacionamento das demandas sociais, diante da disponibilidade de recursos.

\section{ALCANCES E LIMITES DA POLÍTICA IMPLANTADA EM MACEIÓ}

Inúmeros são os desafios para a continuidade dos Projetos Comunidades Saudáveis em Maceió.

Pode-se afirmar que não houve uma efetiva institucionalização do Projeto Comunidades Saudáveis nas duas comunidades, e que as práticas implantadas nem sempre estiveram relacionadas ao ideário do movimento por Cidades/Municípios Saudáveis. O compromisso político do governo da cidade com o desenvolvimento dos projetos é expresso formalmente no discurso, contudo, não houve na prática, nenhum movimento para mantê-los ao longo do tempo.

Há necessidade de levar em consideração o nível de informação/ desinformação dos dirigentes e dos moradores a respeito do Projeto. Participam dele, mas desconhecem seus desdobramentos e a articulação possível que possa ser estabelecida com outros projetos que vão sendo implantados localmente.

A desarticulação de projetos no âmbito da comunidade chama atenção, especialmente no Pontal da Barra, que experimenta projetos como o Revitalização do Bairro, o Comunidades Saudáveis e a Agenda 21. Em tese, todos possuem os mesmos objetivos: melhoria de qualidade de vida, articulação entre setores de governo, participação dos setores organizados da população. Na prática, cada um deles trilha um caminho, sob uma coordenação governamental distinta, e seus resultados não alcançam as expectativas da população local. Um dos motivos para esta situação pode estar assentada na própria engenharia institucional da máquina administrativa, setorizada, parcializada, desconectada, que pode estar criando inúmeros obstáculos que inviabilizam a implementação de qualquer iniciativa. Fica aqui colocada a fragilidade dessas experiências, que mostram as dificuldades de assimilar um novo modelo de desenvolvimento mais participativo e intersetorial. Há uma contradição básica entre a integralidade pretendida e a fragmentação imposta pela lógica das administrações (MOTTA e WESTPHAL 1998).

O caso do Projeto Comunidades Saudáveis é exemplar nesse aspecto. É uma proposta de caráter setorial, já que se originou no interior da Secretaria da Saúde e 
com ação decisiva de agentes sociais no campo da saúde. Constitui-se, portanto, um projeto exclusivo do setor da saúde e como tal é reconhecido. Desde o início, as ações tiveram um tratamento setorial e não estratégico, o que minimiza o potencial de mudança, bem como o envolvimento das diversas áreas de governo. Não se pode deixar de reconhecer que esse Projeto, elaborado pela Secretaria da Saúde da prefeitura, envolveu enorme esforço de pesquisa diagnóstica nos dois primeiros momentos - Momento 1: investigação da realidade, e Momento 2: Construção de um acervo de conhecimentos. Entretanto, avançou-se muito pouco nos desdobramentos inicialmente propostos para o Momento 3: elaboração de propostas com a definição de projetos de intervenção.

Entraves mais significativos decorrem da interrupção de atividades e da falta de definição política em relação ao Projeto, que se apresenta desarticulado na própria área de saúde, embora as equipes do Programa de Saúde da Família (PSF) das duas comunidades entendam que haja objetivos comuns, como detectar problemas locais e realizar o diagnóstico com base na realidade. A experiência do PSF traz consigo a possibilidade de reorganizar os serviços de saúde no nível local. Nas unidades de saúde, as equipes têm se empenhado na sistematização dos dados sociais e epidemiológicos, e os trabalhadores de saúde vêem nessa experiência a possibilidade de estreitar o vínculo com as comunidades. Portanto, há pontos de contato muito importantes que poderiam fortalecer as duas iniciativas. Esta articulação, no entanto, é ainda muito incipiente

Apesar dos problemas observados na implementação do Projeto Comunidades Saudáveis em Maceió, há condições políticas favoráveis para estabelecer fóruns de rediscussão de seus objetivos e de possíveis articulações com outros projetos com objetivos comuns. Um desses espaços é aquele que vem sendo definido com vistas à constituição da Rede Estadual de Municípios Saudáveis, da qual Maceió faz parte, juntamente com outras cidades alagoanas que integram o movimento por Municípios Saudáveis.

Não resta dúvida de que as transformações político-institucionais e as novas formas de participação política local que vêm ocorrendo na cidade, como é o caso do Orçamento Cidadão, abrem um espaço de construção de uma nova institucionalidade, que reconhece a participação da população como uma das 
estratégias fundamentais. Esse espaço pode, ainda, fortalecer a criação de novos canais decisórios que venham a compatibilizar as necessidades e reivindicações dos grupos comunitários com a lógica da política institucional e inserir a sociedade nas decisões, por meio do estabelecimento de parcerias.

Entretanto, percebe-se que o alcance da participação, nas duas comunidades estudadas, está relacionado com a história de participação própria de cada bairro. No Pontal, onde há maior capacidade de organização, e a luta pela ampliação dos direitos sociais é mais efetiva, aparecem mais claramente as dificuldades relacionadas à representatividade, uma vez que os líderes nem sempre conseguem expressar o interesse de toda a coletividade. Mas há um desejo de participar, uma força que agrega e faz com que muitos cidadãos se convertam em lideranças locais reconhecidas, não apenas pela comunidade, mas também pelo poder público municipal. Fica clara, ainda, a relação conflituosa e complementar que se estabelece com o Estado. Pressionam, mas interagem e estão sempre na expectativa de verem suas demandas contempladas.

A atuação da administração municipal é considerada pelos grupos comunitários um desestímulo ao avanço das lutas locais, que pode contribuir para a apatia dos grupos comunitários, que como nos casos estudados, apresentam uma fragilidade organizativa, especialmente nas localidades de Cruz das Almas. Neste caso, a relação predominante das organizações com o nível central é de pressão e não de negociação.

Ao fazer estudos de gestão participativa, COHN (1995b) chama a atenção para casos como este, em que a participação tende a assumir um caráter mais reivindicativo dirigido ao nível central, repondo-se, de forma indireta, a centralização no processo de tomada de decisão.

A necessidade do fortalecimento do contexto institucional é, no entender de JACOBI (1999), uma premissa básica a ser buscada na formulação de políticas públicas. E para que isso ocorra torna-se necessário gerar referenciais para a população a respeito da disponibilidade, acesso e custos de serviços, permitindo-lhes estabelecer vínculos com as percepções dos problemas locais. O grande desafio, para o autor, é formular vínculos viáveis, para melhoramentos eficientes, tanto do ponto de vista técnico quanto social. 


\section{CIDADANIA, DEMOCRACIA E OS DESAFIOS DA GESTÃO COMPARTILHADA}

As transformações políticas das últimas décadas provocaram uma série de mudanças sociais. Democracia e cidadania são processos complexos que vão sendo construídos num contexto de severa crise econômica, em que as desigualdades sociais vão se evidenciando cada vez mais. Nesse processo de construção da democracia e da cidadania, numa sociedade marcada por profundas desigualdades sociais, inúmeras são as dificuldades e desigualdades de participação nos processos políticos. Participação é essencial ao exercício da cidadania, que supõe a construção do direito a uma vida plena em todos os sentidos. Na luta pela democracia, quando se fala em direito, extrapola-se a defesa dos direitos civis e políticos, que passam a ser formulados em termos de direitos coletivos: os sociais e os econômicos.

Numa sociedade como a brasileira, que ainda não vem sendo capaz de preservar os direitos coletivos, as mudanças se dão concomitantemente à consolidação dos direitos sociais, num ambiente político nem sempre favorável, levando à necessidade de se assegurar que as políticas não agudizem ainda mais as desigualdades e a exclusão social.

COSTA (1988) ressalta que no contexto brasileiro de desigualdades existe uma distância entre a noção de cidadania e a realidade da cidadania, que vem subordinada a uma lógica autoritária-corporativa e estabelece a cidadania regulada. De acordo com SANTOS (1976), a concepção de cidadania regulada está vinculada ao critério de ocupação, ou seja, apenas são considerados cidadãos aqueles que são formalmente empregados, em ocupações definidas e reconhecidas pela lei, o que exclui dos direitos de cidadania uma grande parte da população brasileira, que sobrevive do mercado informal de trabalho. Por isso, a conquista da cidadania tem como desafios ampliar, por um lado, a condição de cidadania plena para os inscritos na cidadania regulada e, por outro, incorporar à cidadania plena aqueles expulsos até mesmo da condição de cidadania regulada (COSTA 1998).

A idéia de reafirmação dos direitos de uma cidadania plena, ditada pelos princípios da democracia, significa instituir, como diz BENEVIDES (1991), a 
cidadania ativa, que se traduz em exigências por maior participação política. Como a autora chama a atenção, há de se superar o modelo de representação política centrado no poder público, aos moldes da política tradicional, para construir a representação popular. Assim, ampliar os espaços públicos em que essa participação política seja possível, e sejam reconhecidos os direitos de cidadania, representa condição indispensável à democracia. Para que esses espaços de participação sejam criados, no entender de GONZAGA e RANGEL (1996), é indispensável que haja vontade política de compartilhar a competência decisória e que ocorram sucessivos arranjos na estrutura política formal, que passa a abrigar a ação participativa, estimulando-a permanentemente. Por isso, democracia deve ser entendida como uma forma de existência social, em que o poder não se restringe à esfera do Estado, mas encontrase espalhado em toda sociedade civil. A administração democrática implica ceder poder para os cidadãos e definir reais espaços de participação da sociedade.

Não resta dúvida de que a democratização das relações Estado/sociedade civil e as conquistas no campo constitucional, nos anos de 1980, abrem algumas alternativas para que a sociedade e o próprio indivíduo passem, por meio da participação cotidiana, a intervir nas decisões das políticas que lhe atingem diretamente, fazendo com que haja uma conjugação entre a administração municipal e o nível de mobilização social existente. Ou seja, num contexto onde, ao mesmo tempo, haja pressão social e o poder público esteja muito próximo à comunidade, é de se esperar que as demandas sejam respondidas rápida e eficazmente, fazendo com que a administração pública seja obrigada a criar mecanismos institucionais que identifiquem e reconheçam os desejos e direitos da população, num constante processo de aproximação entre os interesses de governo e os da comunidade (GONZAGA e RANGEL 1996, p.6-7).

Como a participação dos cidadãos na decisão pública está se transformando em um mecanismo efetivo de política à disposição da sociedade, há de se supor que a participação direta dos cidadãos na gestão pública possibilita e estimula a gestão compartilhada e pode contribuir para se chegar a uma sociedade verdadeiramente democrática. No entanto, não bastam mobilizações intermitentes, descontínuas e desarticuladas. Os processos políticos e as decisões públicas exigem efetiva participação. "Esse processo de gestão através do ingresso da cidadania organizada 
na máquina do Estado, possibilita conhecer seu funcionamento e seus limites e estimula a construção de uma relação de co-responsabilidade e de disputa, visando produzir consensos cada vez mais qualificados" (JACOBI 1997:2).

Pode-se dizer que, embora os casos analisados - de Jundiaí e Maceió, representem distintas realidades, ambos enfatizam a participação como aspecto fundamental no desenvolvimento dos projetos por Cidades/Comunidades Saudáveis. O acompanhamento das experiências aponta a complexidade desse processo e os caminhos tortuosos da construção da cidadania vista da perspectiva da participação.

Enumeramos alguns aspectos que são relevantes para a efetivação de parcerias entre o poder público e a sociedade civil.

\section{CRIAÇÃO DE MECANISMOS DE GARANTIA DE ACESSO À INFORMAÇÃo}

A possibilidade de maior acesso à informação permite potencializar mudanças necessárias, orientadas para a defesa de questões de interesse coletivo e motivar ações participativas.

Pode-se observar que os mecanismos de disseminação de informação utilizados para assegurar a gestão conjunta e o desenvolvimento dos projetos na perspectiva do ideário de Cidades Saudáveis, nas cidades de Jundiaí e de Maceió, são diferentes.

O caso de Maceió revela que a implementação do Orçamento Cidadão é uma experiência que vem ampliando os espaços de envolvimento das comunidades nas decisões das políticas públicas. O processo do orçamento participativo baseia-se no intercâmbio de informações e é um espaço de aprendizado de negociação. Em tese, as políticas e ações tornar-se-iam mais transparentes e mais fáceis de serem controladas pela população.

As duas comunidades estudadas, Pontal da Barra e Cruz das Almas, têm participação ativa no Orçamento Cidadão, em que as necessidades e demandas locais são discutidas. Este espaço de diálogo e interlocução permanente pode constituir-se num espaço privilegiado de aprendizado ao exercício da cidadania e de estímulo às práticas de cooperação. Observa-se que as demandas discutidas na fase inicial do Projeto Comunidades Saudáveis, nas duas localidades, foram aquelas priorizadas e 
levadas a cabo na discussão do orçamento da cidade. Se estas vão ser realizadas, ou não, vai ainda depender de uma série de mecanismos de negociação. Como vimos, a reivindicação principal da comunidade do Pontal é por saneamento básico, que significa solucionar o problema de saneamento da Lagoa do Mundaú, que envolve toda a cidade, e as cidades vizinhas. Os loteamentos de Cruz das Almas lutam por uma escola, e suas negociações esbarram num estudo da Secretaria da Educação desfavorável à reivindicação, por entender que as escolas das proximidades podem atender às crianças que ali residem. A justificativa do poder público para o não atendimento de prioridades é a falta de repasses do governo federal.

COHN (1995b), ao analisar a experiência participativa que se deu no município de São Paulo, sob uma gestão democrática e popular, chama a atenção para a separação entre interesses e distintas visões de mundo, que têm reflexos na forma de se trabalhar o conflito que vai se estabelecendo no encaminhamento das demandas. Segundo a autora, na maioria das vezes, as decisões são tomadas por consenso, e o fato de a prefeitura atribuir aos níveis superiores a insuficiência de recursos materiais e humanos faz com que a participação tenha um papel mais reivindicativo e o poder de decisão esteja, ainda, centralizado, o que impede o fortalecimento das organizações comunitárias e das propostas de democratização da gestão pública.

Na cidade de Jundiaí, o Comitê Cidade Saudável, que é a instância coletiva que encaminha o Projeto Jundiaí Cidade Saudável, tem um papel muito limitado. Este Comitê foi criado como instância capaz de assegurar a presença da sociedade civil, de forma efetiva, na defesa dos interesses da população junto ao poder público. Nos dias de hoje, entretanto, suas demandas não têm qualquer repercussão junto ao governo. Sua atuação também não tem repercussões na sociedade civil da cidade e sua representatividade é questionada, até mesmo por seus integrantes. Em cinco anos de existência, poucos foram os mecanismos criados para garantir que as informações atingissem a população toda, o que dificulta qualquer tipo de controle por parte da população. Os jornais locais, que representam muito mais a visão do executivo, deixaram de dar visibilidade ao Projeto, quando este gradualmente perdeu espaço no governo, levando-nos a crer que apenas o que é de interesse do poder público é divulgado. Os concursos, outra forma de disseminar o ideário por Cidades 
Saudáveis, estão dissociados de uma política de governo e, nesse sentido, podem ser entendidos mais como marketing da administração, do que uma estratégia que pode contribuir para a construção de novos valores e novas mentalidades, como deseja o Comitê.

\section{EdUCAÇÃo PARA A CIDAdANIA PARA AMPLIAR OS CANAIS DE PARTICIPAÇÃo}

Pode-se dizer que o estudo de realidades distintas, de Maceió e Jundiaí, permitiu observar que a educação para a cidadania, com vistas à ampliação dos canais de participação, é um dos desafios a ser enfrentado pelas organizações sociais das duas cidades.

O caso de Jundiaí mostra uma face do problema, a dificuldade de ampliar os canais de representação e envolver setores da sociedade que não estão mobilizados para questões vinculadas à melhoria de qualidade de vida. O Comitê Cidade Saudável tem como representantes da sociedade civil, na sua maioria, associações de classe e Organizações Não Governamentais, que representam as camadas mais favorecidas e esclarecidas da população. Mesmo as duas Associações de Bairro que fazem parte do Comitê representam bairros de classe média, que não enfrentam problemas de exclusão em relação ao acesso a bens e serviços. Este grupo reconhece que não representa as classes populares da cidade, que podem ter outros anseios, necessidades e demandas. O grupo tem clareza também de que a ampliação dos canais de participação é um desafio a ser enfrentado. A dúvida sobre como realizar esta tarefa indica a necessidade de pensar em mecanismos de capacitação de lideranças e outras estratégias de educação popular.

Em Maceió, a questão da ampliação dos canais de participação apresenta outros componentes. A comunidade do Pontal tem uma história de participação efetiva na cidade. Todos os projetos de iniciativa da prefeitura incluem necessariamente a comunidade, cujas associações têm poder de mobilização bastante grande. Na última eleição da Associação dos Moradores, cerca de 1000 pessoas votaram. Este número é muito expressivo, se considerarmos que a população da localidade é de 2600 habitantes. Isto não significa que não haja dificuldades de envolver a população nas discussões de melhoria do bairro. Um pequeno número de pessoas participa de diversas instâncias de decisão, como o Conselho de Saúde, o 
Orçamento Cidadão e outros fóruns. Mesmo entre os membros da diretoria da associação, que é formada por 15 pessoas, apenas a metade está engajada mesmo, como relata o presidente da associação. Além disso, o bairro está dividido em dois, e esta divisão parece ser crucial para o encaminhamento de demandas coletivas: $o$ pessoal de baixo e o pessoal de cima, divididos entre os moradores mais antigos, que têm um maior poder de aglutinação, e aqueles que vieram de fora, migraram com a seca, que não têm uma inserção nas lutas coletivas do bairro.

Mesmo considerando que a vivência participativa possa motivar, incentivar e ampliar a participação, ela não é suficiente, já que esta vai além das relações que se estabelecem no interior da comunidade. Fica clara, nesta situação, a dificuldade que as organizações sociais vêm enfrentando para ampliar e formar novos quadros; de um lado, pela sua própria dinâmica interna e, por outro, pelos processos de escolha de seus representantes, em que sempre são selecionados os mais comprometidos com os interesses do bairro (COHN 1995b).

Nos loteamentos de Cruz das Almas, locais onde a população excluída, social e economicamente, vive todo tipo de precariedade, dadas as situações de improviso e insegurança a que está submetida, o aspecto relacionado à educação para a cidadania adquire outros contornos. As duas associação locais têm inserções diferentes nas comunidades que representam. A Associação dos Moradores da Grota do Arroz não representa a comunidade. A ASCONOEL, que integra a Grota do São Rafael e o loteamento Santo Onofre, é nova, tenta constituir-se como porta-voz dos moradores locais e pode ser considerada uma iniciativa, ainda que incipiente, de luta por conquistas de direitos básicos de cidadania e por inclusão de prioridades da população pobre na agenda pública. Estas comunidades, de acordo com os depoimentos de seus representantes, são, na sua maioria, passivas diante da existência dos problemas, o que diminui seu poder nos processos de negociação. Nesse sentido, como aponta JACOBI (1996 p.265), “existe a necessidade de ampliar o envolvimento público através de esforços para elevar o nível de consciência dos moradores e estimular sua participação. A obtenção de um entendimento mais amplo das percepções e atitudes contribui para um esforço de pensar a inserção de determinantes qualitativos na formulação de políticas públicas, tendo como referência a ótica dos moradores”. 
Na busca de ampliação do nível de motivação das comunidades do Pontal da Barra, das Grotas do Arroz e do São Rafael, e do loteamento Santo Onofre, não se pode desconsiderar o papel desempenhado por alguns técnicos das equipes de saúde, que assume contornos significativos por sua ação pedagógica, aspecto relevante no crescimento do grau de consciência da população. A inserção desses técnicos, dos níveis central e local, foi diferente nas localidades do Pontal e nas Grotas. Nesse sentido, o Pontal, considerado privilegiado em organização comunitária, pôde obter melhor resultado de engajamento e interação nas propostas de projetos de melhoria de qualidade de vida, independente dos técnicos. Diz a técnica da Secretaria da Saúde:

“...vocês aqui são privilegiados em relação à Grota, porque vocês tem um potencial humano que é difícil a comunidade ter, quer dizer, vocês todos envolvidos em organizações, interessados, lutando na reunião...porque vocês vão reivindicar, vocês vão incomodar...nós estamos aqui porque nós acreditamos que vocês têm um potencial para levar isso em frente, e vai haver um momento que o técnico se retira da comunidade, e a comunidade assume completamente (GF2, em 28/05/1999).

Os técnicos no Pontal têm trabalhado como facilitadores, incentivando a interlocução do poder público com as associações locais, promovendo capacitações de conselheiros e discussões que auxiliam o exercício da prática participativa junto às instâncias de governo.

Já nas Grotas, os técnicos da saúde viram no Projeto Comunidade Saudável a possibilidade de criar um espaço de mobilização e integração que não existia. Como agentes motivadores, estimularam a participação política dos moradores, sendo que o mais importante resultado desse processo foi o incentivo à criação da ASCONOEL, associação que tenta, ainda com dificuldades, catalisar as demandas dos moradores e constituir-se como canal de representação local.

\section{ARTICUlaÇÃo ENTRE AS INSTÂNCIAS DE PARTICIPAÇÃo}

Assim como a articulação de diversos setores da administração pública é essencial ao estabelecimento de projetos na perspectiva da construção de políticas 
Cidades Saudáveis no Brasil e os processos participativos: os casos de Jundiaí e Maceió

públicas saudáveis, também a articulação entre as diferentes instâncias de participação torna-se fundamental à ampliação do controle social sobre as políticas públicas. JACOBI (1997), ressalta que, no Brasil, não é possível verificar um movimento que articule, numa cidade, as demandas de diversos segmentos da sociedade. As reivindicações são, na sua maioria, específicas e pontuais, o que permite constatar que estão voltadas, prioritariamente, à obtenção de necessidades vitais à reprodução adequada da força de trabalho.

No aspecto relacionado à articulação das instâncias de participação, não são observados avanços significativos nos projetos desenvolvidos nas cidades de Jundiaí e Maceió.

Particularmente, no caso de Jundiaí, houve uma tentativa inédita de reunir todos os Conselhos Municipais num fórum único, como uma estratégia política que poderia contribuir para o desenvolvimento do Projeto Jundiaí Cidade Saudável. O seminário Participação e Cidadania, realizado em 1996, apontou uma série de entraves, sendo que os mais importantes dizem respeito à grande dependência dos Conselhos frente ao poder público, à fragilidade da capacidade articuladora da sociedade civil, à falta de abertura da administração pública para viabilizar o controle social, à falta de mecanismos de comunicação e articulação com os segmentos da sociedade que os conselhos representam, à falta de capacitação dos conselheiros.

Dentre os encaminhamentos, definiu-se a criação de um Fórum Permanente, o estabelecimento de um grupo organizador, com a tarefa de solidificar a união entre os Conselhos, estimular e promover outros encontros. Este processo, no entanto, não teve desdobramentos, mostrando o grande desafio que se coloca para garantir a continuidade de iniciativas de caráter aglutinador das diferentes instâncias de participação. Essa descontinuidade reforça o argumento do próprio grupo e mostra as fragilidades e ambigüidades implícitas no processo participativo na esfera pública, as dificuldades de se promoverem práticas participativas mais efetivas, que possam alterar qualitativamente a dinâmica prevalecente nas relações de poder. $\mathrm{O}$ fato é que hoje, na constituição do Comitê Jundiaí Cidade Saudável, os Conselhos Municipais não se fazem representar, nem mesmo o Conselho de Saúde, que tem severas críticas à administração municipal, acredita no Projeto, e até o desconsidera. 
A experiência do Pontal mostra a dificuldade de articulação de duas instâncias que parecem estar tão próximas: a escola e a unidade de saúde. A escola local tem um papel importante na comunidade e na cidade, na defesa de projetos de qualidade de vida. Sua inserção na Agenda 21 da cidade de Maceió atesta isso. A unidade de saúde, por sua vez, é referência local, dinamizada pela atuação dos técnicos comprometidos com a população. Entretanto, a articulação da escola com o setor da saúde ainda é frágil. Não se pode dizer que não realizem trabalhos conjuntos, mas esses poderiam ser potencializados se houvesse espaços coletivos de discussão e encaminhamento de ações. A direção da escola não tem conhecimento do Projeto Comunidade Saudável, que foi discutido com as associações, mas não considera que a escola tenha sido excluída do processo, uma vez que sua coordenadora pedagógica é vice-presidente da associação dos moradores. Esta, no entanto, não se reconhece como representante da escola, já que não houve um espaço de discussão do projeto com os professores e funcionários na escola.

\section{AVALIAÇÃo E O ACOMPANHAMENTO DOS PROJETOS}

Uma importante dimensão colocada nas ações de co-responsabilidade diz respeito ao controle e acompanhamento dos projetos. Assim como é fundamental a participação de amplos setores no estabelecimento de linhas de ação, torna-se imprescindível o controle e vigilância do cumprimento das responsabilidades. Os mecanismos de avaliação permanente podem contribuir para definição e redefinição dos caminhos a serem percorridos pelos projetos na área pública, bem como para o monitoramento da execução de políticas públicas.

Este não é um processo simples de ser realizado. Conceber e desenvolver a avaliação como um processo formativo implica assumir a exigência e complexidade do trabalho participativo, de construção coletiva e de definição conjunta de variáveis e indicadores a serem utilizados. A falta de desenvolvimento de metodologias adequadas de avaliação, que considerem a globalidade dos problemas, bem como a necessidade de se definir em formas de trabalho para assegurar um processo de avaliação que leve em conta indicadores quantitativos e qualitativos, e que responda a avaliações de processo e resultado, têm sido obstáculos ao acompanhamento das 
ações e dificultado os processos formativos de fortalecimento, negociação, discussão, ação e amadurecimento dos projetos.

O desenvolvimento do Projeto Jundiaí Cidade Saudável pode ser considerado exemplar em relação a esse aspecto. O Projeto existe na cidade há 5 anos e nunca foram criados mecanismos de acompanhamento de suas ações. Nos anos de 1996 e 1997, quando o projeto alcançou maior visibilidade na cidade, havia, de acordo com seu coordenador, uma necessidade muito grande de mostrar os progressos que estavam se delineando. Dentre os vários entraves que se colocaram nesse processo, destaca-se a dificuldade de definir indicadores de qualidade de vida que dessem conta de apontar avanços, para além da perspectiva setorial. Ainda hoje, o Comitê que gerencia as ações do Projeto ressente-se da mesma dificuldade. Com a falta de acompanhamento e avaliação, fica cada vez mais difícil redefinir os objetivos do Projeto e o papel do próprio Comitê. Torna-se, nesse sentido, mais um Projeto que não interfere nas políticas locais e que não avança na ampliação dos canais de participação.

Em Maceió, o problema não é diferente. O Projeto Comunidade Saudável previa, em seu documento de implantação, dois tipos de avaliação: contínua e de impacto. A avaliação contínua incluía a promoção de eventos periódicos com os técnicos da área de saúde e de outras instituições envolvidas no Projeto. Não fica claro, entretanto, se as outras instituições referidas envolveriam também as organizações dos grupos sociais locais. Até o momento, não foram criados mecanismos de avaliação do projeto, o que dificulta entender quais são seus objetivos e desdobramentos. Os depoimentos da prefeita, da Secretária da Saúde e de técnicos da Secretaria da Saúde valorizam a iniciativa como uma proposta de governo. Para as comunidades, no entanto, a fase diagnóstica realizada fez parte de um trabalho do setor da saúde, sem relação com uma proposta mais global. Sem acompanhamento, sem avaliação das ações, sem envolvimento de outros setores da administração, o Projeto Comunidades Saudáveis tem seu desenvolvimento comprometido. 


\section{MANUTENÇÃO DOS PROJETOS E A NECESSIDADE DE AMPLIAR ALIANÇAS}

Como refere FARAH (1999), a manutenção de projetos de políticas públicas tem relação com a capacidade de ampliar alianças entre os diversos setores, baseada em arranjos institucionais que envolvem a ruptura do modelo centrado em instituições ou agências isoladas. Entretanto, essa nova construção só se completa com o estabelecimento de novas formas de articulação entre o Estado e a sociedade civil. A construção de novos mecanismos de articulação entre os diversos atores sociais poderia ter reflexos na superação de ciclos de fluxos e refluxos, normalmente presentes nos projetos sociais, que sofrem permanentes refluxos a cada mudança de governo.

É preciso considerar, como aponta CACCIA BAVA (1999), que embora o termo parceria indique a disposição de uma ação conjunta entre distintas instituições, este não qualifica que ação é esta, quais as relações que se estabelecem e com que objetivos. Há um duplo desafio a ser enfrentado na realização de projetos conjuntos: por um lado, a construção de relações democráticas e horizontais entre as instituições e, por outro, a definição do que essas entidades entendem por interesse público. Nesses processos, freqüentemente estão envolvidas instituições, como empresas, associações comunitárias, igrejas, ONGs, e outras, que possuem tradição de expressar interesses setoriais, muitas vezes corporativos. Diz o autor: o exercício $d a$ parceria é um aprendizado democrático onde a riqueza das contribuições está justamente no aporte diferenciado que cada parceiro pode trazer para o projeto conjunto. Nesse sentido, o aprendizado democrático vai além de reconhecer que as instituições associadas são diferentes, ele requer o reconhecimento por parte de todos de que justamente por que são diferentes é que se potencializam mutuamente, ele requer o respeito à multiculturalidade, à autonomia e independência de cada um de seus integrantes (CACCIA BAVA 1999:14).

As estruturas de poder local e os conflitos que lhes são próprios afetam substancialmente a possibilidade de realização de projetos conjuntos e participativos. Inúmeros projetos na área ambiental, de saúde, de educação, desenvolvidos no Brasil, têm procurado ampliar as alianças e inovar na relação estabelecida entre o Estado e a sociedade civil, buscando constituir-se num processo de aprofundamento 
e ampliação da democracia. Também nesse aspecto, pode-se concluir que as cidades pesquisadas ainda têm muito a avançar.

Na cidade de Jundiaí, os segmentos da sociedade civil que participam do PJCS têm dificuldades de penetrar no espaço público, de ser propositivos e de atuar junto às instâncias de definição de políticas. O Comitê Executivo, composto basicamente por representantes do governo e das associações locais, buscou e tem buscado a parceria do setor privado. A primeira aproximação ocorreu por ocasião dos concursos para estudantes, nos quais a Coca-Cola, empresa localizada na região, contribuiu com o material publicitário e com auxílio para a compra dos prêmios. Outras empresas do comércio local também participaram. De acordo com o primeiro coordenador do PJCS, a forma como os pequenos empresários da cidade se envolveram nos concursos surpreendeu os organizadores, não pelo valor da contribuição, mas pelo entusiasmo com que se inseriram:

"Quando a gente já tinha estipulado os prêmios, na véspera da premiação, os lojistas começaram a aparecer com brindes, um livreiro do shopping ofereceu uma coleção de livros para cada participante e fez questão de entregar pessoalmente. Uma loja apareceu com vários pares de patins..."(EC1)

Dada a receptividade do comércio às iniciativas promovidas pelo Projeto Jundiaí Cidade Saudável, surgiu a idéia de criar mecanismos para formalizar as parcerias e incluir essas pessoas no desenvolvimento do projeto. Entretanto,

"Se por um lado, essas parcerias traziam
recompensas, por outro, traziam uma
preocupação muito grande, porque governos,
no Brasil, não estão habituados a essa prática
com a sociedade civil" (EC1).

$\mathrm{Na}$ realidade, para o coordenador, articulações que estavam se dando, quer com os diferentes segmentos da sociedade civil como os Conselhos, quer com a iniciativa privada, estavam assustando um pouco o governo da cidade, num período em que o evento mais importante eram as eleições municipais de 1996. Este fato demonstra como é difícil a utilização de espaços pela administração municipal e também a dificuldade de cidadãos assumirem um papel relevante no processo de dinamização da sociedade. 
Em Maceió, os projetos em desenvolvimento não têm buscado parceiros, nem mesmo fora do setor da saúde A Universidade Federal de Alagoas é tida como principal colaboradora. É interessante notar que o Pontal da Barra, onde há maior organização e mobilização comunitária, é o local em que ocorre também a parceria com a iniciativa privada, a Trikem, indústria de soda cáustica situada nas proximidades. Esta parceria vem se dando com projetos conjuntos de educação ambiental não é aceita por todos., sendo até motivo de discórdia entre os moradores. Este caso é bastante ilustrativo. A empresa equipou a escola com doze computadores. É a única escola da cidade com equipamentos de informática que, entretanto, estão sem funcionamento por falta de um professor, que deveria ser pago pela prefeitura da cidade.

Coloca-se em evidência a insuficiência ou inoperância do Estado em responder à ampliação de bens e serviços considerados essenciais pelos grupos sociais organizados. Em outras palavras, o Estado deixa de fazer a sua parte, o que coloca sob dúvida sua capacidade de se efetivar como parceiro. Os moradores não aceitam essa situação de "omissão do poder público", e mostram-se indignados: " $a$ gente briga, luta pra conseguir as coisas por baixo e, na outra parte, ninguém ajuda”.

Assim, a proposta de Cidades/Municípios Saudáveis, que tenta inovar na relação Estado/sociedade civil e constituir-se num referencial do novo século, justamente por tentar inserir em seu ideário estratégias de construção de parcerias para o estabelecimento de políticas sociais relevantes para as cidades, não tem apresentado mudanças significativas em relação a esse aspecto. Os projetos Cidades/Municípios Saudáveis estudados se viabilizam numa realidade de participação que se dá desde os anos de 1970 e 1980 no Brasil. A população não acredita na capacidade do Estado para solucionar os complexos problemas sociais, e o Estado, contraditório, atua, às vezes, como gerador de demandas, reconhecendo como seus interlocutores as associações populares, tornando-se mais flexível diante de suas demandas e, na maioria das vezes, atua de forma autoritária e centralizadora, estabelecendo unilateralmente os projetos sociais. Assim, o espaço de negociação dialógica, cuja estruturação se dá por meio da construção de referenciais comuns e de responsabilidade coletiva, ainda está para ser construído. 
Cidades Saudáveis no Brasil e os processos participativos: os casos de Jundiaí e Maceió

\section{CONCLUSÕES}

O presente trabalho permitiu analisar e avaliar possibilidades, limites e avanços dos processos participativos que ocorrem na definição e no gerenciamento de políticas públicas, nos projetos de Promoção da Saúde denominados Cidades Saudáveis.

De acordo com o primeiro objetivo específico proposto, foram identificados e caracterizados os projetos Cidades Saudáveis no Brasil, seus processos de implantação e desenvolvimento. Para isso, foi necessário organizar um conjunto de informações que se apresentavam dispersas, a fim de estabelecer um elo de ligação entre elas.

O levantamento bibliográfico realizado em 1998, fase inicial desta investigação, mostrou alguns poucos trabalhos publicados sobre o tema em anais de congressos e em materiais de divulgação de conferências de saúde de algumas cidades. Esse primeiro levantamento faz perceber que este movimento caminhava lentamente no Brasil. O contato com técnicos dessas cidades, e com os de outras que foram sendo identificadas, permitiu compreender como e porque esse movimento foi se delineando. Esses projetos vêm se dando de diferentes maneiras e seus avanços são bastante restritos. As fases iniciais de implantação dos projetos, que se referem às sensibilizações dos níveis governamentais e da sociedade civil, de modo geral, têm repercussão nas cidades e são facilmente instituídas.

Promover a qualidade de vida tem grande apelo e leva a crer que o governo local tem um objetivo a alcançar, que não se restringe apenas a um projeto de curto prazo. Os pressupostos que sustentam a proposta por Cidades Saudáveis apresentam a possibilidade de um fazer diferente, na perspectiva de futuro, em torno da defesa do interesse público, movimento que só é possível com a democratização e descentralização da gestão pública. No entanto, essas propostas já nascem frágeis. Essa fragilidade faz com que tenham um período de sustentação muito pequeno, sempre relacionado ao tempo de mandato daquele governo que o instituiu.

Foram identificados projetos de desenvolvimento social que atingiram um nível significativo de metas durante o período em que se desenvolveram, mas ao término dos mandatos, o que se conseguiu retrocedeu rapidamente. Projetos que se 
Cidades Saudáveis no Brasil e os processos participativos: os casos de Jundiaí e Maceió

desenvolvem na perspectiva do ideário Cidades Saudáveis são de longo prazo e não podem estar vinculados a apenas um período administrativo e às oscilações de ciclos eleitorais.

Atrelar a sua sustentabilidade à criação de condições de participação, para que as comunidades reconheçam o projeto como seus, criando uma consciência de proteção às suas concretizações, pode ser uma condição necessária, mas certamente não é suficiente. Isso não significa que não se deva investir na criação de mecanismos que promovam mudanças nas relações Estado/sociedade civil, que reflitam nas articulações entre o poder público e o público. Este é um longo percurso a ser construído nas cidades.

Entretanto, outros aspectos se apresentam como importantes à continuidade dos projetos. Um deles está relacionado à implementação de novas formas de gestão, não setorializadas, que alterem as estruturas políticas, sociais e econômicas, modifiquem as tradições culturais e políticas. Estudos em cidades brasileiras têm revelado o fato de que há iniciativas que surgem de problemáticas específicas, como saúde, educação, habitação, e acabam ampliando sua atuação por meio de uma abordagem integral que permita o desenvolvimento social abrangente. Este é um dos desafios, especialmente naquelas cidades onde o setor saúde impulsiona as iniciativas. O setor deve colocar-se de um modo mais amplo, incentivando propostas de mudança da gestão pública.

Outro aspecto está relacionado a ação do poder público que tem sido pouco efetivo na implementação de políticas. A ele cabe exercer um papel nucleador e estruturador de ações, monitorando a execução de políticas públicas e estimulando a dinâmica da gestão compartilhada.

Conforme o segundo objetivo específico deste trabalho, foram analisados os avanços e retrocessos na relação sociopolítico-educacional da gestão estabelecida entre o poder público e os grupos sociais envolvidos nos projetos Cidades Saudáveis. A análise mostra como as cidades vêm implementando seus projetos, como se delineiam as relações e a participação da sociedade civil, como e onde os conflitos vão se constituindo, e pôde, sobretudo, revelar o quanto a prática de uma efetiva gestão compartilhada ainda está longe de ser alcançada. Cercada de contradições, as 
Cidades Saudáveis no Brasil e os processos participativos: os casos de Jundiaí e Maceió

relações que se estabelecem entre o poder público e a sociedade civil têm enormes desafios para implementar os projetos de interesse coletivo.

Nesse aspecto, foi possível perceber que, embora o discurso da participação esteja presente em todos os projetos em desenvolvimento, tentando reafirmar a participação ampliada, que busca uma efetiva contribuição na tomada de decisão técnica e política, as condições gerais políticas das cidades não favorecem a participação efetiva nas questões que envolvem as condições de vida. Pode-se dizer que essas realidades são pobres em participação efetiva. Em outras palavras, as populações não têm se constituído em parceiras das intervenções, co-autoras na implementação de propostas de interesse coletivo. O estudo qualitativo dos casos descritos da cidade de Jundiaí e das comunidades da cidade de Maceió atesta isso. As experiências relatadas permitem inferir que a participação e a gestão conjunta não se introduzem por simples decreto administrativo, em que as populações apenas referendam ou não propostas de caráter técnico-operativo, concebidas em instâncias superiores de decisão.

Os estudos de caso permitiram verificar que a participação, nos projetos que foram se delineando, apresenta progressos e retrocessos, conforme a capacidade de ação e reação dos grupos envolvidos. Os grupos são dependentes de poucas pessoas que participam e discutem temas de interesse da coletividade. Em outras palavras, há muito ainda a aprofundar sobre as questões referentes à legitimidade do processo, especificamente no que se refere à parcela da sociedade que participa dos projetos em andamento nas cidades de Jundiaí e Maceió. Muitas vezes, o processo é legítimo, representa a vontade dos participantes, mas estes não representam, proporcionalmente, a sociedade da qual fazem parte, e determinados segmentos acabam não sendo representados.

Outra questão a ser observada diz respeito aos espaços de poder a serem conquistados. Há de se reconhecer que as manifestações populares ganharam espaço na sociedade brasileira nos últimos 20 anos. Os grupos sociais organizados dependem deste espaço para sua multiplicação e eficácia. Se hoje, por um lado, esses grupos conseguem penetrar facilmente nos espaços públicos que lhes são concedidos pelo Estado, nos quais participam de discussões e de levantamento de prioridades, 
Cidades Saudáveis no Brasil e os processos participativos: os casos de Jundiaí e Maceió

por outro, penetrar nos espaços políticos efetivos de poder, em que se estabelecem os gerenciamentos das políticas, é um grande desafio. Intermediando os interesses dos diferentes setores da sociedade na definição de políticas públicas estão sempre presentes relações clientelistas, corporativas, de cooptação e de repressão.

Estratégias de empowerment das populações, que supõem, entre outras iniciativas, a educação para a cidadania, a socialização e a democratização de informações, poderiam dar condições para que as comunidades se exercitassem no planejamento e na gestão dos projetos, fortalecendo suas capacidades, e até mesmo, permitindo constatar o valor da sustentabilidade das ações. O que se observou, nas experiências descritas, é que as populações não são "donas" de suas políticas e de seus programas. A idéia de compartilhar o poder e estabelecer um novo quadro de relações políticas fica na retórica.

A participação é um processo que implica profundas mudanças sociais e, por isso, gera resistências, já que pode afetar os interesses preestabelecidos e criar obstáculos para a formulação de políticas de gestão compartilhada. Os obstáculos desmotivam continuamente os atores dos grupos sociais, que encontram, no modelo burocrático instituído, um forte motivo de descontinuidade no acompanhamento das ações.

Uma sociedade marcada por profundas desigualdades sociais apresenta também desigualdades e dificuldades referentes à participação do cidadão na vida pública e nos processos de planejamento e gestão. As experiências descritas mostram que a cidadania ainda não se desenha nos espaços da cidade de forma ativa, já que os grupos sociais não têm conseguido alcançar a visão de conjunto dos processos geradores da situação urbana como um todo. Todavia, apontam, também, que as pessoas não estão alheias aos problemas de seu cotidiano. As iniciativas mostram que as pessoas não querem ser excluídas dos processos de decisão, revelam também que há enfrentamentos reivindicativos, e esses podem ser produtores de um espaço próprio de debate com os governos.

As urgências sociais são vastas e profundas, especialmente nas comunidades de Maceió. Enfrentar os difíceis problemas assinalados requer políticas renovadas, que articulem o econômico e o social. Normalmente, os esforços são isolados. Há 
Cidades Saudáveis no Brasil e os processos participativos: os casos de Jundiaí e Maceió

falta de recursos e dificuldades em captá-los em outras instâncias que não o governo federal. Nos municípios, a política setorial prevalece e as soluções têm sido localizadas e paliativas, mesmo quando o enfrentamento dos problemas pede soluções integradas. Assumir a ação intersetorial significa muito mais do que alterar as práticas e a cultura organizacional, significa estabelecer novas relações de cooperação e controle social.

$\mathrm{Na}$ formulação de políticas públicas, interagem diferentes interesses, representados por diferentes setores. Há um discurso que evidencia o desejo de participar, mas a prática mostra que a consolidação de espaços de participação e de negociação de conflitos dificulta o desenvolvimento de projetos na perspectiva da Promoção da Saúde. A efetividade das políticas locais é, ainda, dependente de interesses solidamente organizados, em que a população tem um papel secundário. Esta realidade impede a expansão do novo papel atribuído às cidades e bloqueia a construção de uma estratégia mais geral de enfrentamento das questões sociais que atendam a melhoria das condições de saúde e de qualidade de vida das populações.

Os dois casos estudados mostram claramente a falta de clareza das propostas que se pretendiam implantar, tanto por parte da população, quanto por parte do poder público e dos articuladores sociais. A falta de uma efetiva institucionalização das práticas implantadas, articulando gestão com participação, somada à fragilidade dos canais de representatividade e à falta de uma política de alianças, levaram ao esvaziamento dos projetos nas duas cidades estudadas.

Há de se ter presente, contudo, que importantes passos foram dados pelas cidades de Maceió e Jundiaí, que não podem ser desconsiderados. Ambas as cidades buscaram, num determinado momento, encontrar caminhos para a solução dos complexos problemas vividos por suas populações, diferentes daqueles que vinham sendo propostos. O potencial de articulação de diversos segmentos da sociedade nos momentos iniciais dos dois projetos atesta a possibilidade do fazer conjunto. No entanto, a continuidade dos processos implantados requer ainda atenção. Embora as iniciativas aqui estudadas tenham o mérito de tentar inovar, ainda configuram tendências tímidas em face aos propósitos embutidos nos princípios do movimento por Cidades Saudáveis. 
Como vimos, a construção de projetos na perspectiva do ideário por Cidades Saudáveis é ainda muito nova no mundo todo. Não existe uma fórmula mágica e única que dê conta das diferentes realidades locais. Esses processos demandam fortalecimento dos apoios políticos, que busquem articular o trabalho conjunto para impulsionar a participação e proteger as experiências em andamento, buscando comprometer setores cada vez mais amplos e obter recursos; necessitam, também de maior aporte técnico, por meio do envolvimento mais orgânico das instituições de ensino e pesquisa, como forma de melhorar as condições técnicas para a aplicabilidade dos projetos; precisam buscar apoios nas cidades próximas, para formular estratégias conjuntas baseadas em políticas de integração, para manter, potencializar e/ou construir melhores condições de vida regionais.

$\mathrm{Na}$ lógica da defesa da qualidade de vida há de se investir no fortalecimento da democracia e da cidadania e na articulação de distintos atores sociais que em conjunto devem se mobilizar em defesa do interesse público. Este é o verdadeiro aprendizado que pode promover mudança cultural e democratização das práticas sociais locais. 


\section{REFERÊNCIAS}

Adorno RCF. A trajetória do movimento e a participação: a conduta dos atores sociais na saúde. São Paulo; 1992 [Tese de Doutorado - Faculdade de Saúde Pública da USP].

Adorno RCF, Castro AL. O exercício da sensibilidade: pesquisa qualitativa e a saúde como qualidade. Saúde Soc 1994; 3: 172-85.

Affonso R. Os municípios e os desafios da federação no Brasil. São Paulo Perspect 1996; 10:3-10.

Akerman M. Elaboración de indicadores compuestos para proyectos de ciudades saludables: una invitacion a una accion transectorial. [Texto preparado para la División de Promoción y Protección de la Salud.] Washington (DC): OPS, 1995.

Akerman M, Massei W, Cabral S, Broch A, Cremomese A, Alves TS, Frichenbruder MTM. A concepção de um projeto de Observatório de Qualidade de Vida: relato de uma experiência realizada em Campinas SP. Saúde Soc 1997; 6:83-99.

Almeida ES. Cidade/Município Saudável- a questão estratégica: o compromisso político. Saúde Soc 1997; 6:71-81.

André MEDA. Texto, contexto e significados: algumas questões na análise de dados qualitativos. Cad Pesq 1983; (45):66-71.

André MEDA. Estudo de caso: seu potencial na educação.Cad Pesq 1984; (49):51-4.

Arretche MTS. Políticas sociais no Brasil: descentralização em um Estado federativo. Rev Bras Cien Soc 1999; 14 (40):111-41.

Ashton J. Los orígenes de ciudades sanas. In: Ashton J, organizador. Ciudades sanas. Barcelona: Masson; 1993. p 1-11.

Benevides MVM. A cidadania ativa:referendo, plebiscito e iniciativa popular. São Paulo: Ática; 1991.

Bernestein E, Wallerstein N, Braithwaite R, Gutierrez L, Labonte R, Zimmerman M. Empowerment forum: a dialogue between guest editorial board members. Health Educ Qly 1994; 21:281-94.

Bobbio N, Matteucci G, Pasquino G. Dicionário de Política. Trad. J Ferreira, CC Varriale et al. $2^{\mathrm{a}}$ ed. Brasília: Ed. Brasília; 1986.

Bógus CM. A formação política e o fortalecimento da participação popular em saúde: o caso dos cursos de formação política de conselheiros de saúde do Movimento de Saúde da Zona Leste de São Paulo. São Paulo; 1997. [Tese de Doutorado - Faculdade de Saúde Pública da USP].

Bonciani M, organizador. Saúde, ambiente e contrato coletivo de trabalho: experiências em negociações coletivas. São Paulo: LTr Editora; 1996.

Buss PM. Saúde e qualidade de vida. In: Costa NR, Ribeiro JM, organizadores. Política de saúde e inovação institucional: uma agenda para os anos 90. Rio de Janeiro: ENSP; 1996.p.173-88.

Buss PM. organizador. Promoção da saúde e a saúde pública : contribuição para o debate entre as escolas de saúde pública da América Latina. ENSP. Rio de Janeiro; 1998.

Buss PM. Promoção da saúde e qualidade de vida. Ciência e Saúde Coletiva 2000; 5(1): 163-177.

Caccia Bava S O terceiro setor e os desafios do Estado de São Paulo para o século XXI. São Paulo, 1999. (mimeo)

Cardoso RCL. Movimentos sociais urbanos: balanço crítico. In: Almeida MH, Sorrj B. Sociedade e política no Brasil pós 64. São Paulo: Brasiliense; 1983. p.215-39.

Carta de Fortaleza [Texto apresentado ao I Congresso de Secretários Municipais de saúde das Américas, Fortaleza, Ceará, outubro de 1995].

Carta de Sobral [Texto apresentado ao I Encontro Brasileiro de Municípios Saudáveis. Sobral, Ceará, 1998] 
Cidades Saudáveis no Brasil e os processos participativos: os casos de Jundiaí e Maceió

Carvalho AI. Desenvolvimento recente em conceitos, métodos e práticas de Promoção da Saúde. In: Buss PM, organizador. Promoção da saúde e a saúde pública: contribuição para o debate entre as escolas de saúde pública da América Latina. Rio de Janeiro; 1998. p. 31-45.

Castells ME, Borja J. As cidades como atores políticos. Novos Estud 1996; (45): 152-166.

Cerqueira MT. Promoción de la salud y educacón para la salud: retos y perspectivas. In: Arroyo HV, Cerqueira MT. La promoción de la salud y educación para la salud en América Latina: un análisis sectorial. Puerto Rico:Editorial de la Universidade de Puerto Rico/OPS; 1997. p. 7-47.

Costa MD. Movimentos sociais e cidadania: uma nova dimensão para a política social no Brasil. Rev Adm Pública 1988; 22(2):3-10.

Costa NR. Transição e movimentos sociais: contribuição ao debate da Reforma Sanitária. In: Costa NR, organizador. Demandas populares, políticas públicas e saúde. Petrópolis: Vozes; 1989. p.4565 .

Cohn A, Elias P, Jacobi P. Participação popular e gestão de serviços de saúde: um olhar sobre a experiência do município de São Paulo. Saúde Debate 1993; (38):90-3.

Cohn A. Mudanças econômicas e políticas de saúde no Brasil. In: Laurell AC, organizador. Estado e políticas sociais neoliberais. São Paulo: Cortez; 1995a. p. 225-44.

Cohn A. Saúde e cidadania: análise de uma experiência de gestão local. In: Eibenschutz C organizador. Política de saúde: o público e o privado. Rio de Janeiro: Editora Fiocruz; 1995b.p. 315-27.

Doimo AM. A vez e a voz do popular - movimentos sociais e participação política no Brasil pós 70. Rio de Janeiro: Relume-Dumará/ANPOCS; 1995.

Dowbor L. A reprodução social. Propostas para uma gestão descentralizada. $2^{\mathrm{a}}$ ed. Petrópolis: Editora Vozes; 1999.

Duhl LJ. The healthy city: its funcion and its future. Health Prom 1986; 1:55-60.

Duhl LJ. Ciudades Sanas: mito o realidad? In: Ashton J, organizador. Ciudades sanas. Barcelona: Masson; 1993a. p.15-21.

Duhl LJ. Conditions for healthy cities: diversity game boards and social entrepreneus. Environ Urban. 1993b; 5(2) : 112-24.

Farah MFS. Parcerias, novos arranjos institucionais e políticas locais. In: Fundação Prefeito Faria Lima - CEPAM. O município no século XXI: cenários e perspectivas. ed. esp. São Paulo: CEPAM/Correios; 1999.325-42.

Felicissimo JR. América Latina: movimentos sociais frente à descentralização do Estado. Rev Ad Pública 1994; 28(3):26-43.

Ferraz ST. Cidades saudáveis: uma urbanidade para 2000. Brasília: Paralelo 15; 1999.

Flynn BC. Healthy cities-toward wordwide health promotion. Rev Public Health 1996;17:299-309.

Foucault M. Microfísica do poder. Org. e trad. R Machado. Rio de Janeiro: Edições Graal; 1979.

Fundação IBGE. Censo demográfico de 1991. Situação demográfica, social e econômica: primeiras considerações - Estado de Alagoas. Rio de Janeiro; 1995.

Fundação IBGE. Contagem da população: 1996. Rio de Janeiro; 1997.

Fundação IBGE. Malha digital do Brasil: situação em 1997. [CD ROM]; Rio de Janeiro; Departamento de Cartografia; 1999.

Fundação SEADE. Pesquisa municipal unificada (PMU). São Paulo; 1998.

Giddens A. A terceira via: reflexões sobre o impasse político atual e o futuro da socialdemocracia. São Paulo/Rio de Janeiro: Record; 1999.

Gohn MG. Teoria dos movimentos sociais: paradigmas clássicos e contemporâneos. São Paulo: Edições Loyola; 1997. 
Cidades Saudáveis no Brasil e os processos participativos: os casos de Jundiaí e Maceió

Goldstein G, Kickbusch I. Una ciudad sana es una ciudad mejor. Salud Mundial. 1996; 49(1): 4-6.

Gonzaga A, Rangel R. Cidadania, município e movimentos sociais: o caso do município de Vitória. Rev Adm Publica 1996; 30(4):5-21.

Goumans M. Innovations in a fuzzy domain. Healthy Cities and (health) policy development in the Netherlands and the United Kingdom. Maastricht; 1997. [Phd Thesis- Faculty of Health Sciences- University of Maastricht,].

Guimarães IGR. Câmaras setoriais: histórico, constituição e perspectivas. São Paulo Perspect 1994; $8(3): 15-22$.

Haguette TMF. Metodologias qualitativas na sociologia. $2^{\text {a }}$ ed. São Paulo: Vozes; 1990.

Hancock T. The evolution, impact and significance of the healthy cities/healthy communities movement. J Public Health Policy 1993a; 14(1): 5-18.

Hancock T Cuidad sana: utopías y realidades. In: Ashton J, organizador. Ciudades sanas. Barcelona: Masson; 1993 b. p.23-9.

Ianni O. A era do globalismo. Rio de Janeiro: Civilização Brasileira; 1996.

Inojosa RM. Intersetorialidade e a configuração de um novo paradigma organizacional. Rev Adm Pública 1998; 32(2):35-48.

IPEA/IBGE/UNICAMP. Caracterização e tendências da rede urbana do Brasil. Campinas:UNICAMP; 1999 (Coleção Pesquisas 3).

Jacobi P. Movimentos sociais e políticas públicas. São Paulo: Cortez; 1989.

Jacobi P. Participação e gerência dos serviços de saúde: desafios e limites no município de São Paulo. Rev Adm Pública 1992a; 6(2):32-43.

Jacobi P. Descentralização municipal e a participação dos cidadãos: apontamentos para o debate. In: Cadernos da Nona Conferência Nacional de Saúde; 1992b, ago 9-14; Brasília. V.1, p.113-20.

Jacobi P, Teixeira MAC. Orçamento participativo: co-responsabilidade na gestão das cidades. São Paulo Perspec. 1996; 10:119-28.

Jacobi P. Ampliação da democracia e participação- desafios na democratização da relação poder público/sociedade civil no Brasil. São Paulo; 1996. [Tese de Livre-Docência - Faculdade de Educação da USP].

Jacobi P. Educação para a cidadania: participação e co-responsabilidade. Debates Soc-Amb 1997; (7): $1-2$.

Jacobi P. Cidade e meio ambiente. Percepções e práticas em São Paulo. São Paulo: Annablume; 1999.

Junqueira LAP. Mudança uma causa compartilhada: do ERSA ao SUS. São Paulo; 1996. [Tese de Doutorado- Faculdade de Saúde Pública da USP].

Junqueira LAP. Novas formas de gestão na saúde: descentralização e intersetorialidade. Saúde Soc 1997; 6(2):31-46.

Junqueira LAP. Descentralização e intersetorialidade: a construção de um modelo de gestão municipal. Rev Adm Pública 1998; 32(2):11-22.

Junqueira LAP e Inojosa RM. Desenvolvimento social e intersetoarialidade: a cidade solidária. São Paulo, FUNDAP; 1997.

Kliksberg B. A iniqüidade na América Latina: um tema-chave para o desenvolvimento e o perfil ético da sociedade. Rev Adm Pública 1998; 32: 177-220.

Kowarick L, organizador. As lutas sociais e a cidade: São Paulo - passado e presente. Rio de Janeiro: Paz e Terra; 1988. 
Cidades Saudáveis no Brasil e os processos participativos: os casos de Jundiaí e Maceió

Labonté R. Políticas públicas saudáveis. [Apresentado na Conferencia Internacional de Promoción de la Salud. Santa Fé de Bogotá. In: Para promover la salud en el municipio n²2: lecturas básicas; 1992.México:57-74].

Labonté R. Health promotion and empowerment: reflections on profissional practice. Health Educ Q 1994; 21:253-68.

Lalonde M. A new perspective on the health of Canadians. Ottawa: Government of Canada; 1974.

Lefèvre F, Lefèvre AMC. .Novas abordagens metodológicas em pesquisa qualitativa. São Paulo: Faculdade de Saúde Pública da USP; 1999.

Levin LS; Ziglio E. Health promotion as an investment strategy: considerations on theory and practice. Health Prom Int 1996; 11:33-40.

Luck H Pedagogia interdisciplinar. Fundamentos teórico-metodológicos. São Paulo: Vozes; 1995).

Mato D. Guia de evaluar participación social en estratégias y programas de salud en el nível local : Version preliminar; Caracas; 1996.

Médici AC. Economia e financiamento do setor saúde no Brasil: balanços e perspectivas do processo de descentralização. São Paulo: Faculdade de Saúde Pública da USP; 1994. ( AdSaúdeSérie Temática,3).

Melo MA. Crise federativa, guerra fiscal e "hobbesianismo municipal": efeitos perversos da descentralização? São Paulo Perspec 1996; 10(3):11-20.

Mendes EV. Uma agenda para a saúde. São Paulo: HUCITEC; 1996.

Minayo MCS. Abordagem antropológica para avaliação de políticas sociais. Rev Saúde Pública 1991; 25 (3):233-8.

Minayo MCS. O desafio do conhecimento. Pesquisa qualitativa em saúde. São Paulo/Rio de Janeiro: Hucitec/ABRASCO, 1992.

Minayo MCS. Pesquisa social: teoria método e criatividade. Petrópolis: Vozes; 1994.

Miranda TG. Movimentos sociais no Brasil: balanço de literatura 1970-1995. São Paulo;1997. [Tese de Doutorado- Faculdade de Filosofia Letras e Ciências Humanas da USP].

Motta PR. Participação e descentralização administrativa: lições de experiências brasileiras. Rev Adm Pública 1994; 28:174-94.

Motta RMM , Westphal MF. Participación de la población en el establecimiento y la dirección de políticas públicas saludables. [Trabalho apresentado na XVI World Conference of the International Union for Health Promotion and Education. 1998, San Juan de Puerto Rico].

MP vai fazer auditoria na Trikem. O Jornal 1998 nov 27; cad A/6.

Nunes E. Poder local, descentralização e democratização: um encontro difícil. São Paulo Perspect 1996; 10(3):32-9.

[OMS] Organização Mundial da Saúde. Promoção da saúde: Carta de Ottawa, Declaração de Adelaide, Sundsval e Santa Fé de Bogotá. Trad. de LE Fonseca. Brasília: Ministério da Saúde; 1996.

[OPS] Organización Panamericana de la Salud. El movimiento de municipios saludables en America. Washington (DC); 1992.

[OPS] Organización Panamericana de la Salud. La participación social en el desarollo de la salud: experiências latinoamericanas. Washington (DC); 1995.

[OPS] Organización Panamericana de la Salud. Municipios saludables.. Washington (DC);1997. Comunicación para la Salud; 11.

[OPS] Organización Panamericana de la Salud. La salud en las Américas. Washington (DC); 1998; 2v. Publicación Científica;569. 
Cidades Saudáveis no Brasil e os processos participativos: os casos de Jundiaí e Maceió

[OPS] Organización Panamericana de la Salud. Planificación local participativa: metodologías para la promoción de la salud en América y el Caribe. Washington (DC); 1999a.

[OPS] Organización Panamericana de la Salud. Propuesta para desarrollar un marco conceptual y operativo para evaluar municipios saludables. Washington (DC); $1999 \mathrm{~b}$.

[OPS] Organización Panamericana de la Salud. Taller de evaluación de municipios saludables: Informe final. Washington (DC); 1999c.

Ottawa charter for health promotion. Health Prom, 1987; 1(4):405-62.

[PAHO] Pan American Health Organization. Caribbean health promotion charter. First Caribbean conference on health promotion. Washington (DC); 1993.

[PAHO] Pan American Health Organization Experience with Healthy Municipalities in Latin America. International Conference on Healthy and ecological Cities . Madrid; 1995.

[PAHO] Pan American Health Organization. The healthy municipalities movement: a strategy for health promotion in Latin America. Washington(DC); 1997.

[PAHO] Pan American Health Organization. The healthy municipalities movement A setting approach and strategy for health promotion in Latin America and the Caribben. (Draft). Washington (DC); 1999.

Paoli MC. Movimentos sociais no Brasil: em busca de um estatuto político. In: Hellmann M. Movimentos sociais e democracia no Brasil. São Paulo; Marco Zero; 1995.p.24-55.

Park RE. A cidade: sugestões para a investigação do comportamento humano no meio urbano In: Velho OG. O fenômeno urbano. $3^{\text {a }}$ ed. Rio de Janeiro: ZAHAR; 1976. p. 27-67.

Patton MQ. Qualitative evaluation methods. London: Sage Publications, Beverly Hills; 1987.

[PMJ] Prefeitura do Município de Jundiaí. Jundiaí e o Projeto Cidades Saudáveis: propostas preliminares para um documento síntese da estrutura, processo de trabalho e objetivos desejados. Jundiaí; 1994a.

[PMJ] Prefeitura do Município de Jundiaí. Seminário Cidades Saudáveis.: resumo das discussões; Jundiaí; 1994b.

[PMJ] Prefeitura do Município de Jundiaí. Relatório Projeto Jundiaí Saudável: período de novembro de 1994 a abril de 1995: resumo executivo, Jundiaí; 1995.

[PMJ] Prefeitura do Município de Jundiaí. Projeto Jundiaí Cidade Saudável. Relatório de Viagem à Toronto- Canadá. Jundiaí; ag 1997.

[PMJ] Prefeitura do Município de Jundiaí. Jundiaí: perfil do município. Cad de Planej ;1998:v I.

[PMJ] Prefeitura do Município de Jundiaí. Projeto Jundiaí Cidade Saudável: histórico da implantação do Projeto Cidade Saudável no Município de Jundiaí: Relatório Síntese. Jundiaí; s/d.

[PMM] Prefeitura Municipal de Maceió, Instituto Théo Brandão. Maceió 180 anos de história.Maceió: Instituto Théo Brandão; 1995.

[PMM] Prefeitura Municipal de Maceió. Secretaria Municipal de Saúde. Departamento de Atenção à Saúde. Divisão de Educação em Saúde. Projeto de implantação das comunidades saudáveis em Maceió para melhoria da qualidade de vida das populações. Maceió (Al); 1996.

[PMM] Prefeitura Municipal de Maceió. Secretaria Municipal de Saúde. Experiência de comunidade saudável. Levantamento sócio-econômico, epidemiológico e cultural da comunidade do Pontal da Barra. Maceió (Al); 1998.

[PMM] Prefeitura Municipal de Maceió. Secretaria Municipal de Saúde. Experiência de comunidade saudável nas Grotas do Arroz e do Rafael: Levantamento sócio-econômico, cultural e epidemiológico da comunidade da população. Maceió ( $\mathrm{Al})$, s/d.

[PMM] Prefeitura Municipal de Maceió/ Empresa Municipal de Turismo de Maceió . Bairro Pontal da Barra. Maceió. s/d. 
Cidades Saudáveis no Brasil e os processos participativos: os casos de Jundiaí e Maceió

[PMM] Prefeitura Municipal de Maceió. Secretaria Municipal de Educação/ Centro de Educação Ambiental São Bartolomeu. Agenda 21 das escolas municipais de Maceió : Primeiro documento, Maceió; 1999.

[PNUD]. Programa das Nações Unidas para o Desenvolvimento. Desenvolvimento humano e condições de vida: indicadores brasileiros - atlas de desenvolvimento humano no Brasil. IPEA/FJP/IBGE; 1998.

Poland BD, Rootman I, O’Neill M, Green L, Feather J, Poel D. Issues in evaluation: healthy community initiatives. In: Thurston WE, Sieppert J, Wiebe VJ Doing health promotion research: the science of action. Calgary: Alberta.University of Calgary; 1998. p. 83-102.

Rice M, Rasmusson E. Ciudades sanas en países en desarrollo. In: Ashton J, organizador Ciudades sanas. Barcelona: Masson; 1993. p. 69-82.

Rosen G. Uma história da saúde pública. São Paulo: Editora UNESP/HUCITEC/ABRASCO; 1994.

Roux G. La participación social, factor dinamizador de la estrategia de Municipios Saludables. [Apresentado ao Tercero Congreso de las Americas de Municipios y Comunidades saludables; 1999 mar ; Medellin, Colombia].

Ruiz G. Análisis de la participación social en el movimiento municipios saludables en América Latina. Québec; 1998. [Tese de Maestría; Faculté de Médicine; Université Laval].

Sader E. Quando novos personagens entram em cena. Rio de Janeiro: Paz e Terra; 1988.

Salvadori MAB. Histórico da cidade. In: Prefeitura do Município de Jundiaí. Jundiaí- perfil do município. Cad Planej 1998. 1: 13-19.

Santos JLF, Westphal MF. Práticas emergentes de um novo paradigma de saúde: o papel da universidade. Estudos Avanç 1999; 13(35):71-88.

Santos M. A urbanização brasileira. $3^{\mathrm{a}}$ ed. São Paulo: HUCITEC; 1996.

Santos WG. Cidadania e justiça: a política social na ordem brasileira. $3^{\mathrm{a}}$ ed. Rio de Janeiro: Editora Campus; 1994.

[SESA] Secretaria do Estado de Saúde do Paraná; Organização Panamericana de Saúde (OPAS). Município saudável: iniciativas de implantação. Curitiba SESA; 1996.

Slater D. Nuevos movimientos sociales y viejas preguntas políticas. Rev Fora 1989; (8):5-19.

Souto ALS, Kayano J, Almeida MA, Petrucci VA. Como reconhecer um bom governo? O papel das administrações municipais na melhoria da qualidade de vida. São Paulo:Pólis;1995. (publicações Pólis, 21)

Sousa Santos B. A reinvenção solidária e participativa do Estado. [Palestra proferida no Seminário Internacional Sociedade e a Reforma do Estado; 1998; São Paulo, Brasil].

Sposati A, Falcão MC. A assistência social brasileira: descentralização e municipalização. São Paulo: EDUC; 1990.

ST-Pierre M, O’Neill M, Dupriez A. Directory oh the Networks of Healthy Communities and Cities in Canada. Monograph n. 1E The Monographs of the Quebec World Health Organization Collaborating Centre for the Development ef Healthy Cities and Towns; 1997.

Simulação de Acidente na Trikem mobiliza o Pontal. O Jornal 1998 nov 27;cad A/6.

Taschner SP. Mudanças no padrão de urbanização: novas abordagens para a década de 90. Espaço Debates 1992; (36):77-90.

Thiollent MJM. Crítica metodológica, investigação social e enquete operária. $5^{\text {a }}$ ed. São Paulo. Ed. Polis; 1987.

Valla V V, Stotz EN. Participação Popular, educação, saúde: teoria e prática. Rio de Janeiro; Relume-Dumará; 1993. 
Cidades Saudáveis no Brasil e os processos participativos: os casos de Jundiaí e Maceió

Valla V V. Participação popular e saúde: a questão da capacitação técnica no Brasil. In: Valla, V V, Stotz . In:. Participação popular, educação, saúde: teoria e prática. Rio de Janeiro; RelumeDumará; 1993. p. 55-86.

Veras MPB, Pompeo A, Coelho JAT, Nery Jr JM. Desejada ou temida a participação da sociedade civil no processo de planejamento urbano. São Paulo Perspect 1994; 8: 114-23.

Viana ALD. Novos riscos, a cidade e a intersetorialidade das políticas públicas. Rev Adm Pública; 1998, 32(2):23-33.

Vince- Whitman C, Jones A, Garcia T, Hagen N. Rapid assessment and action planning process: RAAPP. A means to build capacity and infrastructure for promoting health through schools. Geneva: World Health Organization; 1997. [Fourth International Conference on Healh Promotion, Jakarta, Indonesia]

Waldman EA. A transição epidemiológica: tendências e diferenciais dos padrões de morbimortalidade em diferentes regiões do mundo. O Mundo da Saúde 2000; 24(24): 10-8.

Wallerstein N. Powerlessness, empowerment, and health: implications for health promotion programs. Am J Health Prom 1992; 6:197-205.

Werna E. As políticas urbanas das agências multilaterais de cooperação internacional para países em desenvolvimento. Espaço e Debates 1996; (39): 10-12.

Westphal MF. Participação popular e políticas municipais de saúde: o caso de Cotia e Vargem Grande Paulista. São Paulo; 1992. [Tese de Livre Docência Faculdade de Saúde Pública da Universidade de São Paulo].

Westphal MF. Gestão participativa dos serviços de saúde: pode a educação colaborar na sua concretização? Saúde Debate 1995; (47): 41- 9.

Westphal MF; Bogus CM;Faria MM. Grupos Focais: experiencias precursoras em programas educativos em saúde no Brasil. Bol Oficina Sanit Panam 1996; 120: 472-82.

Westphal MF , Motta RMM, Bógus CM Cidades Saudáveis: a formação de uma rede brasileira. Jornal do CONASEMS. ed. esp., 1998. p. 16-9.

Westphal MF La participación social y la propuesta de municipalidades saludables.[Apresentado ao Tercero Congreso de las Americas de Municipios y Comunidades saludables; 1999 mar ; Medellin, Colombia].

Westphal MF, Ziglio E. Políticas públicas e investimentos: a intersetorialidade. In: Fundação Prefeito Faria Lima (CEPAM). O município no século XXI: cenários e perspectivas. ed. esp. São Paulo: CEPAM/Correios; 1999. p.111-21.

Westphal MF. O movimento de municípios saudáveis e a conquista da qualidade de vida. Ciência e Saúde Coletiva 2000;5(1): 39-51.

[WHO] World Health Organization. WHO healthy cities: a programme framework- a review of the operation and future development of the WHO cities programme. Geneva; 1995.

[WHO] World Health Organization. Healthy cities. The magazine of the WHO 1996; 49 (1): 2-39.

\section{JORNAIS DA CIDADE DE JUNDIAí ${ }^{32}$}

1. 1994 Jundiaí participa da discussão do Projeto Cidade Saudáveis. Jornal da Cidade 1994 out 30.

2. 1994 Workshop discute "Cidades Saudáveis". Jornal da Cidade 1994 nov 15; cad. Geral:6.

3. 1994 Workshop discute "Cidades Saudáveis". Jornal de Jundiaí 1994 nov 15; cad. Cidades:8.

\footnotetext{
${ }^{32}$ Estão listados 95 jornais da cidade de Jundiaí, publicados entre 1994 e 1999. Para efeito de contagem excluímos 2 deles, os de nº75 e 76, de 1997, por não terem sido identificados os nomes dos jornais onde foram publicados.
} 
Cidades Saudáveis no Brasil e os processos participativos: os casos de Jundiaí e Maceió

4. 1994 Participantes do workshop se reuniram. Jornal da Cidade 1994 nov 17.

5. 1994 Projeto Cidades Saudáveis é apresentado em Jundiaí. Jornal da Cidade 1994 nov 17; cad. Geral:11.

6. 1994 Participantes do workshop sereuniram. Jornal da Cidade 1994 nov 19.

7. 1994 Projeto deve interligar secretarias. Jornal de Jundiaí 1994 nov 17; cad. Cidades:10.

8. 1994 Projeto rediscute Cidades Saudáveis. Jornal de Jundiaí 1994 nov 20; cad. Especial:19.

9. 1994 Começa elaboração do programa Cidades Saudáveis. Jornal da Cidade 1994 nov 26; p. 2.

10. 1994 Planejamento discute elaboração do programa. Jornal da Cidade 1994 dez 02.

11. 1994 Comissão apresenta proposta de elaboração do programa. Jornal da Cidade 1994 dez 09; cad. Geral:5.

12. 1994 Grupo se reúne para discutir projeto. Jornal de Jundiaí 1994 dez 10; cad. Cidades:8.

13. 1994 Comissão define grupos de trabalho para o programa. Jornal da Cidade 1994 dez 11; cad. Geral:14.

14. 1994 Jundiaí saudável. Jornal da Cidade 1994 dez 23; p. 2.

15. 1995 Grupo cria comitê e discute projetos. Jornal da Cidade 1995 fev 4.

16. 1995 Comissões discutem projeto. Jornal da Cidade 1995 mar 04; cad. Geral:4.

17. 1995 Canadense elogia trabalho da prefeitura. Jornal da Cidade 1995 mar 18; cad. Geral:6.

18. 1995 Cidades Saudáveis, uma questão de atitude. Jornal da Cidade 1995 abr 04.

19. 1995 Vila Arens conhece o Projeto Cidade Saudável. Jornal da Cidade 1995 jun 25: cad. Geral:15.

20. 1995 "Projeto Jundiaí Cidade Saudável" chega à Vila Arens. Jornal da Cidade 1995 jun 27; cad. Cidade:8.

21. 1995 Gac se reúne para discutir Projeto Cidade Saudável. Jornal de Jundiaí 1995 jun 27.

22. 1995 Comunidade da Vila Arens conhece a Cidade Saudável. Jornal da Cidade 1995 jun 29.

23. 1995 Comunidade da Vila Arens se organiza. Jornal de Jundiaí 1995 jun 29; cad. Cidades:8.

24. 1995 Coordenador apresenta Projeto "Cidades Saudáveis" aos moradores da Vila Arens. Jornal de Jundiaí 1995 jun 30; cad. Cidades:8.

25. 1995 Prefeitura ouve Conselhos Municipais. Jornal de Jundiaí 1995 jul 01; cad. Cidades:9.

26. 1995 Projeto exige participação da comunidade. Jornal de Jundiaí 1995 jul 01; cad. Cidades:8.

27. 1995 Canadenses analisam investimento na cidade. Jornal de Jundiaí 1995 jul 23; cad. Especial:8.

28. 1995 Comissão canadense estuda investimento. Jornal de Jundiaí 1995 jul 28; cad. Cidades:7.

29. 1995 Canadenses debatem idéias saudáveis com jundiaienses. Jornal da Cidade 1995 jul 29; cad. Geral:5.

30. 1995 Municipalização atrai comissão de canadenses. Jornal de Jundiaí 1995 jul 29; cad. Cidades:8.

31. 1995 Entidades conhecem projetos sociais dos canadenses. Jornal da Cidade 1995 ago 02.

32. 1995 Estudantes vão apresentar propostas para uma cidade mais saudável. Jornal da Cidade 1995 ago 17.

33. 1995 Concurso será lançado nesta quinta. Jornal da Cidade 1995 ago 23.

34. 1995 Prefeitura lança hoje o concurso "Cidade Saudável". Jornal da Cidade 1995 ago 24.

35. 1995 Benassi lança concurso que vai movimentar escolas. Jornal da Cidade 1995 ago 25. 
Cidades Saudáveis no Brasil e os processos participativos: os casos de Jundiaí e Maceió

36. 1995 Lançado concurso "Cidade Saudável". Jornal de Jundiaí 1995 ago 25; cad. Cidades:11.

37. 1995 Projeto propõe multas para quem sujar ou estragar a cidade. Jornal da Cidade 1995 ago 29.

38. 1995 Concurso vai premiar redação. Jornal de Jundiaí 1995 set 09; cad. Cidades:10.

39. 1995 Concurso está mobilizando mais de 60 mil estudantes. Jornal da Cidade 1995 set 14; cad. Educação:5.

40. 1995 Alunos discutem cidadania e participam de concurso. Jornal da Cidade 1995 set 21; cad. Educação:7.

41. 1995 Concurso Jundiaí Cidade Saudável entrega prêmios. Jornal da Cidade 1995 out 12; cad. Geral:6.

42. 1995 Concurso premia no Sábado. Jornal de Jundiaí 1995 out 12; cad. Cidades:12.

43. 1995 Prefeito entrega prêmios para os melhores do "Cidade Saudável". Jornal da Cidade 1995 out 14; cad. Geral:12.

44. 1995 Concurso dá bicicleta e micro no Paineiras. Jornal de Jundiaí 1995 out 15; cad. Cidades:14.

45. 1995 Cidades Saudável: estudantes recebem os prêmios no Paineiras. Jornal da Cidade 1995 out 17.

46. 1995 Cidade Saudável Vila Arens discute o projeto. Jornal da Cidade 1995 nov 25; cad. Geral:3.

47. 1995 Vila Arens discute Projeto Cidade Saudável. Jornal de Jundiaí 1995 nov 28; cad. Cidades:2.

48. 1995 Comerciantes vão ao prefeito, para apoiar mudanças. Jornal da Cidade 1995 nov 30; cad. Geral:11.

49. 1995 Grupo cria comitês e discute projetos. Jornal da Cidade 1995 dez 04.

50. 1995 Cidade Saudável Conselho avalia ações de 95. Jornal da Cidade 1995 dez 08.

51. 1996 Maciel abre o "Cidades Saudáveis". Jornal da Cidade 1996 mar 05; cad. Geral:7.

52. 1996 Participação no Congresso mostra que Jundiaí está no caminho certo. Jornal da Cidade 1996 mar 08; cad. Geral:3.

53. 1996 Projeto quer aprimorar intercâmbio com canadenses. Jornal da Cidade 1996 mai 11.

54. 1996 Equipe avalia participação no Congresso. Jornal da Cidade 1996 jun 15.

55. 1996 Cidade Saudável. Concurso está previsto para novembro. Jornal da Cidade 1996 ago 07.

56. 1996 Projeto Cidade Saudável promove encontro com candidatos. Jornal da Cidade 1996 ago 8.

57. 1996 Projeto Cidade Saudável realiza debate na cidade. Jornal de Jundiaí 1996 ago 10; cad. Política:3.

58. 1996 Miguel conhece amanhã do projeto. Jornal da Cidade 1996 ago 15.

59. 1996 Projeto Cidade Saudável fará concurso em novembro. Jornal da Cidade 1996 ago 20.

60. 1996 Prefeitura organiza concurso "Jundiaí - Cidade Saudável". Jornal da Cidade 1996 Out 19.

61. 1996 Os estudantes vão apresentar propostas para melhorar Jundiaí. Jornal da Cidade 1996 out 24.

62. 1996 "Cidade Saudável" é tema de concurso infantil. Jornal de Jundiaí 1996 out 24; cad. Cidades:11.

63. 1996 Termina amanhã o prazo de entrega dos trabalhos. Jornal da Cidade 1996 out 31.

64. 1996 Trabalhos ficam expostos no Maxi a partir da próxima semana. Jornal da Cidade 1996 nov 14; cad. Geral:3. 
Cidades Saudáveis no Brasil e os processos participativos: os casos de Jundiaí e Maceió

65. 1996 Nome dos vendedores será divulgado no dia da premiação. Jornal da Cidade 1996 dez 04; cad. Geral:6.

66. 1996 Trabalhos são selecionados nas escolas durante esta semana. Jornal da Cidade 1996 nov 06; cad. Geral:3.

67. 1996 Concurso Cidade Saudável reuniu 90 mil alunos. Jornal da Cidade 1996 dez 11; cad. Geral:11.

68. 1996 Organizadores analisam o concurso escolar Jundiaí Cidade Saudável. Jornal da Cidade 1996 dez 17.

69. 1996 Projeto Cidade Saudável promove encontro com candidatos. Jornal da Cidade 1996 ago 08; cad. Geral/política:3.

70. 1997 Canadenses em Jundiaí. Jornal da Cidade 1997 jun 26; cad. Geral:10.

71. 1997 Cidade Saudável: canadenses voltam à Jundiaí. Jornal da Cidade 1997 jun 27; cad. Geral:3.

72. 1997 Jundiaí pode ter o programa piloto. Jornal de Jundiaí 1997 jun 27; cad. Geral:5.

73. 1997 Jundiaí e Fortaleza representam o país no Canadá. Jornal da Cidade 1997 jul 22; p. 2.

74. 1997 Canadá qualifica Jundiaí como Cidade Saudável. Jornal de Jundiaí 1997 jul 22; cad. Geral:3.

75. 1997 Projeto Canadá vai estudar Jundiaí. **** 1997 jul 22.

76. 1997 Jundiaí é eleita para programa Cidade Saudável. **** 1997 jul 23.

77. 1997 Jundiaí é Cidade Saudável. Jornal da Cidade 1997 ago 15; cad. Geral:3.

78. 1997 Comitê do projeto Cidade Saudável discute estrutura. Jornal da Cidade 1997 out 11.

79. 1997 Cidade Saudável. Jornal da Cidade 1997 out 15; cad. Geral:7.

80. 1997 Projeto promove encontro. Jornal da Cidade 1997 nov 26.

81. 1997 Primeiro encontro acontece no Sábado. Jornal da Cidade 1997 nov 27.

82. 1997 Cidade Saudável, amanhã. Jornal da Cidade 1997 nov 28.

83. 1997 Jundiaí discute amanhã Projeto Cidades Saudáveis no SENAC. Jornal de Jundiaí 1997 nov 28; cad. Ecologia:8.

84. 1997 Primeiro encontro lota o SENAC. Jornal da Cidade 1997 nov 30.

85. 1997 Encontro reúne Cidades Saudáveis. Jornal de Jundiaí 1997 dez 01; cad. Cidades:5.

86. 1998 Definida a equipe do Cidade Saudável. Jornal da Cidade 1998 mai 07; cad. Geral:6.

87. 1998 Cidade Saudável define comitê executivo. Jornal de Jundiaí 1998 mai 12.

88. 1998 Simpósio discute Cidade Saudável com segurança. Jornal da Cidade 1998 mai 28; cad. Geral:3.

89. 1998 Polícias assumem pacto de união. Jornal de Jundiaí 1998 mai 28; cad. Polícia:8.

90. 1998 Cidade Saudável. Jornal da Cidade 1998 jul 03.

91. 1998 Cidades Saudáveis. Jornal da Cidade 1998 jul 08: cad. Geral:3.

92. 1998 E mais. Jornal de Jundiaí 1998 jul 11; cad. Cidades:6.

93. 1998 Seminário mostra o que é Cidade Saudável 1998 jul 11.

94. 1998 Cidade Saudável faz seminário. Jornal da Cidade 1998 jul 30; cad. Geral:6.

95. 1998 Seminário discute Cidade Saudável. Jornal da Cidade 1998 ago 07. 


\section{ANEXO 1 - ROTEIRO DE ESTIMATIVA RÁPIDA}

1. Quando teve início o projeto Cidades Saudáveis em seu município?

2. Quais as razões que motivaram o início do projeto Cidades Saudáveis em seu município?

3. Quais as instituições, organizações da sociedade civil e /ou indivíduos estiveram envolvidas no início do projeto?

4. Quais as instituições, organizações da sociedade civil e/ou indivíduos estão envolvidas no desenvolvimento de projeto?

5. Fale sobre algumas políticas governamentais que você conhece relacionadas ao movimento por Cidades Saudáveis.

6. A inclusão do seu município no movimento por Cidades Saudáveis tem promovido melhoria do nível educacional da população?

7. A inclusão do seu município no movimento por Cidades Saudáveis tem promovido melhoria do nível de saúde da população?

8. A inclusão do seu município no movimento por Cidades Saudáveis tem promovido melhoria no meio ambiente ?

9. A inclusão do seu município no movimento por Cidades Saudáveis tem auxiliado na promoção do desenvolvimento econômico do seu município?

10. A inclusão do seu município no movimento por Cidades Saudáveis tem promovido a colaboração entre os membros da comunidade?

11. A inclusão do seu município no movimento por Cidades Saudáveis tem promovido o desenvolvimento de políticas intersetoriais/ integradas?

12. Quais esforços colaborativos/parcerias que você conhece que têm auxiliado no desenvolvimento do projeto Cidades Saudáveis em seu município?

13. Existe uma rede de comunicação que garante a troca de informações sobre o desenvolvimento do projeto?

14. Quais os mecanismos de comunicação utilizados pela coordenação do projeto para garantir o acesso às informações?

15. Quais as fontes financeiras que dão sustentação ao projeto?

16. O projeto tem ajuda financeira de instituições externas? Quais?

17. O projeto conta com apoio técnico de instituições externas ao município? Quais são eles?

18. Descreva as ações, programas e serviços criados a partir da introdução de seu município no movimento 


\section{ANEXO 2 -QUADROS ILUSTRATIVOS DA CONSTRUÇÃO DO DISCURSO DO SUJEITO COLETIVo (DSC)}

\section{QUADRo 1 - CORTE TEMPORAL do Projeto Jundiá Cidade SAUdÁvel}

\begin{tabular}{|c|c|}
\hline $\begin{array}{l}\text { CORTE } \\
\text { ENQUADRAMENTO } \\
\text { TEMPORAL }\end{array}$ & DESCRIÇÃO \\
\hline $\begin{array}{l}\text { Evento 1: divulgação da } \\
\text { discussão do projeto CS } \\
\text { (JC - out/1994) }\end{array}$ & $\begin{array}{l}\text { O evento ocorrerá entre os dias } 14 \text { e } 18 \text { de novembro, reunindo } \\
\text { profissionais de diversas áreas e deverá contar com a presença do } \\
\text { canadense Jack Lee - autor do projeto piloto na cidade de Toronto, no } \\
\text { Canadá - para divulgar os resultados do trabalho registrados no país. }\end{array}$ \\
\hline $\begin{array}{l}\text { Evento 2: Workshop } \\
\text { sobre CD (JC - } \\
\text { nov/1994) }\end{array}$ & $\begin{array}{l}\text { O evento reúne profissionais de diversas áreas conta com a presença do } \\
\text { canadense Jack Lee - autor do projeto piloto na cidade de Toronto, no } \\
\text { Canadá - para divulgar os resultados do trabalho registrados no país. }\end{array}$ \\
\hline $\begin{array}{l}\text { Evento 3: Apresentação } \\
\text { do projeto CIDADE } \\
\text { SAUDÁVEL (JJ - } \\
\text { nov/1994) }\end{array}$ & $\begin{array}{l}\text { Apresentação do projeto CIDADE SAUDÁVEL no Hotel estância Vale } \\
\text { das Vinhas, para representantes da Prefeitura de Jundiaí e sociedade. }\end{array}$ \\
\hline $\begin{array}{l}\text { Evento 4: Reunião no } \\
\text { Paço Municipal (JC - } \\
\text { nov/1994) }\end{array}$ & $\begin{array}{l}\text { Reunião no gabinete com o prefeito André Benassi, com a secretária de } \\
\text { Saúde, Ana Maria Müller, o coordenador de Planejamento Marco } \\
\text { Antônio Orlando e o assessor especial, Francisco Carbonari }\end{array}$ \\
\hline $\begin{array}{l}\text { Evento 5: Primeira } \\
\text { reunião para elaboração } \\
\text { do programa CIDADE } \\
\text { SAUDÁVEL (JC - } \\
\text { nov/1994) }\end{array}$ & $\begin{array}{l}\text { Reunião realizada pela Secretaria de Saúde e a Coordenadoria de } \\
\text { Planejamento, para discutir a elaboração do programa CIDADE } \\
\text { SAUDÁVEL. }\end{array}$ \\
\hline $\begin{array}{l}\text { Evento 6: Segunda } \\
\text { reunião da comissão } \\
\text { para elaboração do } \\
\text { programa CIDADE } \\
\text { SAUDÁVEL (JC - } \\
\text { dez/1994) }\end{array}$ & $\begin{array}{l}\text { Encontro reunindo aproximadamente } 30 \text { profissionais de diversas áreas } \\
\text { técnicas responsável pela elaboração do programa CIDADE } \\
\text { SAUDÁVEL }\end{array}$ \\
\hline
\end{tabular}


Cidades Saudáveis no Brasil e os processos participativos: os casos de Jundiaí e Maceió

QUADRO 2 -COMO A MÍDIA RECONSTROI O CONCEITO CIDADE SAUDÁVEL COMO FATO PÚBLICO

\begin{tabular}{|c|c|}
\hline \multicolumn{2}{|l|}{ CATEGORIA 1} \\
\hline EXPRESSÃO CHAVE & IDÉIA CENTRAL \\
\hline $\begin{array}{l}\text { O projeto representa hoje um novo conceito do processo } \\
\text { de melhoria de qualidade de vida (JC - out/1994) }\end{array}$ & $\begin{array}{l}\text { Processo de melhoria de qualidade de } \\
\text { vida }\end{array}$ \\
\hline $\begin{array}{l}\text { A proposta é conscientizar a comunidade da importância } \\
\text { da realização de ações conjuntas para garantir a saúde da } \\
\text { população }\end{array}$ & $\begin{array}{l}\text { Conscientização da comunidade para } \\
\text { ações conjuntas }\end{array}$ \\
\hline $\begin{array}{l}\text { Despertar no indivíduo a consciência de que ele é um ser } \\
\text { que integra e reflete as condições do meio social }\end{array}$ & Indivíduo reflete meio social \\
\hline $\begin{array}{l}\text { Questões relacionada a salários, educação e moradia em } \\
\text { geral, influenciam a saúde da população, provocando } \\
\text { desajustes sociais }\end{array}$ & $\begin{array}{l}\text { Causas do desajuste social e fatores } \\
\text { que influenciam na saúde }\end{array}$ \\
\hline $\begin{array}{l}\text { A violência nos grandes centros urbanos pode ser } \\
\text { associada à falta de condições sócio-econômicas da } \\
\text { população }\end{array}$ & $\begin{array}{l}\text { Associação entre violência e falta de } \\
\text { condições sócioeconômicas }\end{array}$ \\
\hline $\begin{array}{l}\text { O objetivo é integrar todas as áreas da Prefeitura, } \\
\text { sindicatos e entidades de classe }\end{array}$ & $\begin{array}{l}\text { Intersetorialidade e integração entre } \\
\text { instituições e/ou entidades }\end{array}$ \\
\hline $\begin{array}{l}\text { Atualmente os grandes centros urbanos refletem as } \\
\text { disparidades da sociedade, contrastando as cenas do } \\
\text { mundo moderno ao retrato dramático dos altos índices } \\
\text { de pobreza }\end{array}$ & $\begin{array}{l}\text { Contrastes da sociedade nos grandes } \\
\text { centros urbanos }\end{array}$ \\
\hline $\begin{array}{l}\text { O conceito de cidade sustentável engloba a questão } \\
\text { ambiental, ecossistema, a organização da sociedade e o } \\
\text { controle da população sobre as decisões que afetam a } \\
\text { saúde e o bem-estar. }\end{array}$ & $\begin{array}{l}\text { Conceito de cidade sustentável } \\
\text { englobando questões } \\
\text { socioeconômico-ambientais }\end{array}$ \\
\hline $\begin{array}{l}\text { O projeto alerta para a importância do resgate da herança } \\
\text { cultural e biológica do indivíduo. }\end{array}$ & $\begin{array}{l}\text { Resgate da herança cultural e } \\
\text { biológica }\end{array}$ \\
\hline $\begin{array}{l}\text { Um ambiente de alta qualidade, seguro e limpo } \\
\text { (incluindo a qualidade de moradia) }\end{array}$ & Ambiente de alta qualidade \\
\hline
\end{tabular}




\section{QUADRO 3 - COMO A MÍDIA PUBLICIZA O DISCURSO DOS ATORES SOCIAIS}

\begin{tabular}{|c|c|c|}
\hline \multicolumn{3}{|c|}{ CATEGORIA 2} \\
\hline QUEM? & COMO SE ENVOLVEM? & $\begin{array}{c}\text { IDÉIA } \\
\text { CENTRAL }\end{array}$ \\
\hline $\begin{array}{l}\text { Secretaria de Saúde e a Coordenadoria de } \\
\text { Planejamento promovem, entre os dias } 14 \text { e } \\
18 \text { de novembro, atividades em Jundiaí para } \\
\text { discutir o Projeto CS (JC-out/1994) }\end{array}$ & $\begin{array}{l}\text { Promoção de atividades para } \\
\text { discussão do Projeto CS }\end{array}$ & $\begin{array}{l}\text { Promoção de } \\
\text { atividades do } \\
\text { Projeto CS }\end{array}$ \\
\hline $\begin{array}{l}\text { A secretária de Saúde, Ana Maria Müller, } \\
\text { explicou que o projeto representa hoje um } \\
\text { novo conceito do processo de melhoria da } \\
\text { qualidade de vida (JC - out/1994) }\end{array}$ & Secretária explica o projeto CS & $\begin{array}{l}\text { Explicação do } \\
\text { Projeto CS }\end{array}$ \\
\hline $\begin{array}{l}\text { O assessor técnico da Coordenadoria de } \\
\text { Planejamento, Paulo Fernando Capucci, } \\
\text { explicou que sete cidades estarão } \\
\text { participando do programa no Brasil, a fim de } \\
\text { promover a criação de uma rede da Cidades } \\
\text { Saudáveis }\end{array}$ & $\begin{array}{l}\text { Assessor técnico explica o programa } \\
\text { CS }\end{array}$ & $\begin{array}{l}\text { Explicação do } \\
\text { Projeto CS }\end{array}$ \\
\hline $\begin{array}{l}\text { Capuccci explicou que atualmente os grandes } \\
\text { centros urbanos refletem as disparidades da } \\
\text { sociedade, contrastando as cenas do mundo } \\
\text { moderno ao retrato dramático dos altos } \\
\text { índices de pobreza. "Com isso nós esperamos } \\
\text { poder realizar um intercâmbio com os } \\
\text { profissionais de outros países, trocando } \\
\text { experiências, técnicas e tentando aprimorar } \\
\text { os conhecimentos". }\end{array}$ & $\begin{array}{l}\text { Capucci explica as disparidades da } \\
\text { sociedade }\end{array}$ & $\begin{array}{l}\begin{array}{l}\text { Explicação das } \\
\text { disparidades da }\end{array} \\
\quad \text { sociedade } \\
\\
\\
\text { Intercâmbio } \\
\text { com profis- } \\
\text { sionais de } \\
\text { outros países }\end{array}$ \\
\hline $\begin{array}{l}\text { Coordenadoria de Planejamento e a } \\
\text { Secretaria da Saúde iniciaram ontem uma } \\
\text { série de atividades em Jundiaí para discutir o } \\
\text { Projeto CS (JC - nov/1994) }\end{array}$ & Início de atividades para discutir CS & $\begin{array}{l}\text { Atividades para } \\
\text { discussão de } \\
\text { CS }\end{array}$ \\
\hline $\begin{array}{l}\text { Jack Lee aproveitou o dia para conhecer as } \\
\text { zonas periféricas, distrito industrial e os } \\
\text { principais pontos do centro da cidade }\end{array}$ & $\begin{array}{l}\text { Jack Lee visita alguns pontos da } \\
\text { cidade }\end{array}$ & $\begin{array}{l}\text { Visitas à } \\
\text { pontos da } \\
\text { cidade }\end{array}$ \\
\hline & & \\
\hline
\end{tabular}




\section{ANEXO 3 - INTEGRA DOS DISCURSOS DO SUJEITO COLETIVO}

\section{Categoria 1}

\section{Reconstrução do conceito de Cidade Saudável como fato público}

\section{DSC do conceito de Cidade Saudável}

Uma cidade saudável é aquela onde os moradores vivem e trabalham em condições que favoreçam sua saúde, melhorando seu meio ambiente - a qualidade da construção e localização das casas, transporte e trânsito, saúde, educação, produção e distribuição de alimentos, segurança pública, lazer, salubridade dos locais de trabalho, da água e do ar.

A concepção de CS surgiu com uma evolução do conceito de educação sanitária baseada em conceitos psicossociais norte-americanos e de reflexões a respeito dos mecanismos que provocam mudanças de comportamento e melhoria do meio ambiente físico e social".

No conceito de cidade saudável a saúde deve deixar de ser vista como parte assistencial para ser uma forma de vida saudável; não é apenas uma questão de assistência médica é algo muito mais abrangente que precisa ser discutido com outros setores.

No conceito de cidade saudável, pessoas de diferentes setores partilharam de uma visão semelhante sobre o que é preciso para se ter uma cidade melhor.

A cidade sustentável engloba a questão ambiental, ecossistema, a organização da sociedade e o controle da população sobre as decisões que afetam a saúde e o bem-estar.

- Uma cidade saudável deveria esforçar-se para prover:

- Um ambiente de alta qualidade, seguro e limpo (incluindo a qualidade de moradia;

- Um ecossistema estável agora e sustentável a longo prazo;

- Uma comunidade forte, mutuamente apoiada e não exploratória;

- Um alto grau de participação e controle pela população sobre as decisões que afetam sua vida, saúde e bem estar;

- encontro de necessidades básicas (alimento, água, moradia, salário, segurança e trabalho) para todas as pessoas da cidade;

- Acesso a uma ampla variedade de experiências e recursos, com a perspectiva de ocorrer um amplo contato, interação e comunicação;

- Uma economia diversificada, vitalizada e inovadora;

- fortalecimento de uma conexão com o passado, com a herança cultural e biológica de seus antepassados e com outros grupos e indivíduos;

- Um forma de agir compatível e enriquecedora das caraterísticas anteriores;

- Um ótimo nível de saúde e cuidados médicos acessíveis a todos;

- $\quad$ Alto status de saúde (altos níveis de saúde com baixos níveis de doença.

\section{DSC das características do Projeto Jundiaí Cidade Saudável}

Jundiaí vem desenvolvendo o projeto 'CS', numa parceria entre a Prefeitura Municipal e os bairros interessados, que visa o alcance dos padrões sanitários mínimos da população, ou seja, a saúde obtida através dos trabalhos com nível de vida e de trabalho, renda, cultura, política e administração pública; 
Cidades Saudáveis no Brasil e os processos participativos: os casos de Jundiaí e Maceió

O projeto Jundiaí Cidade Saudável reúne um conjunto de ações e atividades que procura ajudar na melhoria dos níveis de saúde da população, com programas que envolvam tanto a comunidade, como o Executivo e o Legislativo.

O grande objetivo do 'CS', de acordo com o coordenador geral do projeto, Paulo Fernando Capucci, é uma espécie de parceria do morador do bairro com a Prefeitura, da comunidade com a fábrica que se localiza no local.

Queremos que as próprias pessoas possam nos ajudar. É importante colocar o governo no seu papel, mas não se pode deixar que toda a responsabilidade fique só com ele.

O projeto não é governamental, a busca é pela construção de uma organização na cidade para a prática na obtenção da saúde.

A atenção especial deve ser com distribuição de renda, geração de empregos, industrialização, condições ambientais, poluição, fontes poluidoras, enfim, as condições de vida de cada cidadão.

O projeto da cidade saudável a ser implantado em Jundiaí implica em alternativas para melhorar qualidade de vida do jundiaiense e se espelha no Canadá A grande mudança é que os canadenses passaram a tomar conta de assuntos governamentais: centenas e centenas de cidadãos passaram a se envolver em questões de moradia, segurança, saúde e muitos outros problemas a eles relacionados e fizeram pressão para que a prática de desenvolvimento integrado passasse a fazer parte de suas vidas.

Questões relativas ao uso de drogas e segurança da mulher, estariam sendo resolvidas com rapidez nos países em que o projeto foi adotado.

O objetivo do projeto é integrar todas as áreas da Prefeitura, sindicatos e entidades de classe.

O projeto alerta para a importância do resgate da herança cultural e biológica do indivíduo.

O objetivo é integrar todas as secretarias municipais, sindicatos, entidades de classe e a população para discutir e resolver problemas sociais em conjunto e melhorar a qualidade de vida das pessoas.

O projeto prevê a criação de uma série de comissões para manter uma ligação direta entre técnicos e a população.

As pessoas tem com a saúde uma relação de propriedade muito intensa No caso específico da área de saúde, a proposta é encampar não só questões de assistência médica, mas também de moradia, saneamento e lazer $\mathrm{O}$ projeto pretende dar mais saúde não só aos cidadãos, mas também ao próprio ambiente urbano.

Entre os principais pontos discutidos pelo CS estão as necessidades consideradas básicas pela população: alimento, água, moradia, salário, segurança e trabalho.

Queremos uma Polícia Militar trabalhando em parceria com a Comunidade.

Começamos a pensar Jundiaí saudável por inteiro, como a queremos no futuro.

É um trabalho que exige longo prazo, muita discussão, afinação e ação.

Como é gostoso poder pensar que Jundiaí pode e deve melhorar.

Como é gostoso poder sentir e ver que algumas pessoas estão interessadas em se conseguir uma cidade saudável em todos os aspectos.

Mais gostoso ainda, é saber que ações nesse sentido estão partindo de pessoas que ocupam cargos importantes dentro do Poder Público.

É delicioso ter a consciência de que estamos agindo em favor de futuras gerações, buscando novos conceitos, pensando longe, estrategicamente, unindo esforços para cuidar bem do que é de interesse comum: Jundiaí, a Cidade em que vivemos.

O projeto é extremamente importante em qualquer cidade e Jundiaí, que já é relativamente saudável, poderá ficar ainda melhor com a participação da sociedade.

As ações podem se concretizar com programas e projetos da Prefeitura, da comunidade ou das duas juntas. 
Cidades Saudáveis no Brasil e os processos participativos: os casos de Jundiaí e Maceió

A Prefeitura espera que a comunidade participe, cada vez mais, das ações do governo, assumindo um importante papel no desenvolvimento permanente da cidade.

A população não deve esperar que apenas as autoridades municipais realizem melhorias nos bairros da cidade. $\mathrm{O}$ processo deve ser inverso, os moradores que conhecem melhor do que ninguém as carências e dificuldades de seu bairro, é que têm de batalhar para isso.

O primeiro passo para a junção dos trabalhos é o interesse das diversas comunidades em participar.

Algumas medidas do projeto já podem ser vistas na prática pela população da Vila Arens. O policiamento comunitário do bairro é uma delas.

Com esse sistema, o policial passa a interagir e a integrar a comunidade.

Ele ficará a par dos problemas e das necessidades dos moradores.

Esse projeto só funcionará se crescer em função da participação da comunidade e da vontade do setor público.

\section{DSC do diagnóstico}

É grande a influência do processo de urbanização sobre o perfil de saúde A urbanização combinada a pobreza, muitas vezes, estimula a inclusão de um acúmulo de problemas nas cidades contribuindo, inclusive, para o surgimento de doenças típicas dos países subdesenvolvidos.

A ONU divulgou recentemente um estudo alertando os especialistas das áreas de saúde e de controle social para o constante crescimento populacional.

Atualmente os grandes centros urbanos refletem as disparidades da sociedade, contrastando as cenas do mundo moderno ao retrato dramático dos altos índices de pobreza.

Questões relacionada a salários, educação e moradia em geral, influenciam a saúde da população, provocando desajustes sociais.

A violência nos grandes centros urbanos pode ser associada à falta de condições sócio-econômicas da população.

\section{DSC sobre a participação das organizações da sociedade civil}

Para se chegar a uma cidade e comunidades saudáveis, existe um longo processo, que tem como ponto de partida a questão cultural e o envolvimento da comunidade.

Com efeito, é importante o papel do cidadão para se construir uma Cidade Saudável, bem como o fortalecimento do controle social e parceria, ampliação dos projetos específicos e o aumento e diversificação da participação nos bairros.

A participação da sociedade na resolução dos problemas a ela relacionados é muito importante.

Os projetos são feitos e dependem da participação da população para dar certo.

A Prefeitura de Jundiaí espera que a comunidade participe, cada vez mais assumindo um importante papel no desenvolvimento permanente da cidade. 


\section{Categoria 2}

\section{Como a mídia publiciza o discurso dos atores sociais}

\section{DSC do poder público}

A secretária de Saúde, Ana Maria Müller, explicou que o projeto representa hoje um novo conceito do processo de melhoria da qualidade de vida.

Coordenador Marco Antônio Orlando afirmou que aproximadamente 40 profissionais deverão participar do Workshop.

Orlando disse que as cidades de Curitiba, Belo Horizonte, Santos, Diadema, São Vicente e São Paulo também deverão apresentar propostas para a implantação do programa.

A Prefeitura de Jundiaí deverá incorporar o projeto Cidades Saudáveis, de acordo com a secretária da Saúde, Ana Maria Müller, em data ainda não definida.

Conforme Ana Müller, o trabalho, ainda está na primeira fase, com estudos sobre sua viabilidade e o momento em que será implantado.

Segundo a secretária da Saúde, Ana Müller, o nível de saúde é o resultado de uma interdependência.

Jundiaí tem todas as possibilidades de fazer um projeto para a comunidade, explicou Ana.

Para Marco Antônio Orlando, coordenador de planejamento do município, esta é uma grande oportunidade para se conhecer melhor o trabalho e a disposição do grupo, incluindo-se a possibilidade de monitoração do Canadá.

Para a secretária de Saúde, Ana Maria Müller, a abertura da visão de saúde, apresentada por Lee, vem ao encontro do trabalho desenvolvido pela Secretaria de Saúde.

Ana Müller informou que os participantes do Workshop estarão reunidos nesta sexta-feira, no Paço Municipal.

Hugo Silimbani Neto, coordenador do sistema de coleta Cata Treco, disse que a reunião definiu os comitês de trabalho e seus participantes.

A proposta de implantar o projeto Cidades Saudáveis foi reeditada pelo ex-titular da pasta Marco Antônio Orlando e pela secretária de Saúde, Ana Maria Müller, adequando o texto para Jundiaí.

De acordo com ele, a população têm demonstrado grande entusiasmo em participar das reuniões.

O coronel João Carlos Gomes Pacheco, anunciou uma intensificação do policiamento comunitário.

Num primeiro instante, o policial realizará a ronda do bairro à pé para conhecer melhor o bairro e para que as pessoas o reconheçam.

Em forma de painel, os representantes expuseram aspectos da administração pública, como planejamento, orçamento, serviços, saúde, educação, bem-estar social, habitação e polícia.

diretor da Semis, Jezimiel Antunes, afirmou que a Secretaria atende cerca de 250 crianças em situação de rua e que $15 \%$ da população jundiaiense tem renda familiar de um salário mínimo. "A Prefeitura desenvolve programas de integração social e geradores de renda, que atende também adultos desempregados. Como o Canadá poderia nos ajudar?"

O secretário de Planejamento Sérgio Del Porto realizou uma explanação sobre o trabalho da Prefeitura.

O prefeito concorda que a estrutura está errada. Estamos trabalhando visando reestruturação da administração.

O secretário apresentou alguns dados. "Conseguimos melhorar a qualidade de vida em Jundiaí. 97\% dos nossos domicílios têm água tratada de qualidade excelente e rede de esgoto. $100 \%$ têm coleta de lixo e $100 \%$ das nossas vias são iluminadas". 
Cidades Saudáveis no Brasil e os processos participativos: os casos de Jundiaí e Maceió

A secretária da Saúde, Ana Müller, e o presidente da Fumas (Fundação Municipal de Ação Social), Pe. Paulo André Labrosse, explicaram para a comissão canadense a participação das secretarias em relação aos conselhos municipais.

O Conselho Municipal de Habitação permite uma participação maior da sociedade civil", explica o presidente da Fumas, Pe. Paulo André.

José Roberto Parimoschi, diretor da secretaria de finanças, explicou a proveniência da verba da Prefeitura.

Para o prefeito André Benassi, tanto o concurso como o projeto Cidade Saudável "é uma iniciativa que só pode ser apoiada e é aplaudida" pela administração pública. E temos o dever de agradecer e apoiar a sociedade quando ela se organiza em iniciativas como essa", disse.

Agora, através do Congresso, busca-se uma integração entre todos os municípios que desenvolvem projetos semelhantes", explica o coordenador de Planejamento da Prefeitura de Jundiaí, Sérgio Del Porto.

A arquiteta Ana Paula Pinheiro, também do planejamento, complementa lembrando que há cidades desenvolvendo bons projetos de melhoria de qualidade de vida. "O que falta é justamente intercâmbio, independente do nome que o projeto tenha em cada cidade.

Essa e outras conclusões do Congresso estão na Carta de Campinas, documento produzido pelos participantes.

O caso é que, como admite o coordenador de Planejamento, é preciso de uma maior divulgação do projeto junto à população.

Ele falou de seus projetos para Jundiaí, que incluem pontos como melhoria e preservação do meio ambiente, transporte e habitação $\mathrm{O}$ engenheiro Pedro Bigardi fala de seus projetos para Jundiaí.

A integrante da comissão organizadora do CS, Marta Regina Pavan Solsi, disse que a divulgação do concurso nas escolas tem sido bastante receptiva, porque perguntam quem vai selecionar os melhores trabalhos. "Eles dizem que não vai ter marmelada, porque é a própria comunidade quem vai escolher os finalistas".

\section{DSC das coordenações do PJCS}

O assessor técnico da Coordenadoria de Planejamento, Paulo Fernando Capucci, explicou que sete cidades estarão participando do programa no Brasil, a fim de promover a criação de uma rede da Cidades Saudáveis

O assessor técnico de Coordenadoria de Planejamento, nomeado coordenador de comissão, Paulo Fernando Capucci, afirmou que os representantes deverão preparar um relatório sobre as atividades desenvolvidas a fim de analisar as condições da cidade.

Capucci, disse que a partir da próxima semana, a Secretaria de Saúde e a Coordenadoria de Planejamento devem iniciar uma série de reuniões promovendo a continuidade das discussões sobre o projeto Cidades Saudáveis.

A Coordenadoria de Planejamento e a Secretaria de Saúde realizaram hoje a segunda reunião da comissão responsável pela elaboração do programa CS.

O assessor técnico da Coordenadoria de Planejamento, coordenador da comissão Paulo Fernando Capucci, afirmou que a reunião deverá definir o encaminhamento do trabalho.

O assessor técnico da Coordenadoria de Planejamento, coordenador da comissão responsável pela elaboração do programa CS, Paulo Fernando Capucci, afirmou que a equipe deverá concluir hoje o trabalho de levantamento das informações para a apresentação do primeiro relatório.

Cappuci afirmou que já foram realizadas duas reuniões, a fim de estabelecer o calendário de trabalho e discutir as prioridades do programa. 
Cidades Saudáveis no Brasil e os processos participativos: os casos de Jundiaí e Maceió

A idéia é definir o background, dimensionando as propostas, comentou. De acordo com o coordenador, está sendo organizado também um documento detalhado para a avaliação e divulgação do programa para a comunidade.

O coordenador considerou positivo o resultado do encontro, destacando o interesse do grupo em dimensionar a estratégia de trabalho para a conclusão do programa.

O coordenador do grupo, Paulo Capucci, informou que foram identificados quatro projetos para integrar o "Jundiaí Cidade Saudável”: o Cata Treco, o Conheça seu Bairro, o Policiamento de Bairro e Educação de Trânsito.

A idéia é definir ações, estratégia e prioridades das áreas em estudo, a fim de garantir os resultados do programa”, ressaltou Capucci.

O coordenador do Projeto Cidades Saudáveis, Paulo Capucci, expôs aos moradores da Vila Arens em reunião realizada no salão paroquial da igreja Nossa Senhora da Conceição - ontem à noite, as linhas básicas do projeto, em grande parte já levado adiante pelo Grupo de Apoio à Comunidade (GAC) da Vila Arens.

Foi através de Capucci que a secretária de saúde, Ana Müller e o antigo coordenador de Planejamento, Marco Antônio Orlando, entraram em contato com Jack Lee.

Mas já temos pessoas se organizando nesse sentido no Anhangabaú, Vila Hortolândia e Distrito Industrial", diz o coordenador.

Nós somos uma ponte para os vários setores da sociedade. Não somos donos das soluções nem mágicos", conclui Capucci.

Capucci disse que a importância do encontro com os canadenses foi estabelecer uma agenda de discussões e ajuda mútua.

Capucci, disse que a comissão canadense escolheu Jundiaí "por ser uma cidade de porte médio e que está ativamente empenhada no projeto".

Capucci disse que o próximo passo é ter diagnósticos dos problemas e trocar experiências "de ajuda mútua",

Capucci desembarcou de volta há poucos dias e explica que foram quatro meses de contatos nas cidades de Toronto, Etobicoke e Scarborough, onde o Cidade Saudável está bem desenvolvido.

Como eu iria ter que ficar quatro meses por lá, aproveitei para acertar visitas oficiais como representante do projeto Cidade Saudável de Jundiaí, observa.

Manteve contatos com a Agência de Desenvolvimento Internacional do Canadá.

Eles têm interesse em escolher cinco cidades brasileiras para promover programas de assistência técnica na área de conservação ambiental (especialmente na destinação do lixo e poluição) e treinamento de pessoal.

Tudo que ele viu durante sua estada no Canadá já começou a ser discutido com os integrantes do Projeto CS de Jundiaí, em uma reunião nessa sexta-feira.

De acordo com um dos coordenadores do Projeto Jundiaí Cidade saudável, Sérgio Pio Bernardes, a cidade conta com bons exemplos da preocupação da Administração com a qualidade de vida da população.

Para este ano, segundo Bernardes, entre as diversas estratégias do projeto estão a criação de um novo concurso.

Segundo o coordenador geral do Projeto, Paulo Fernando Capucci, o concurso foi um trabalho conjunto com as Delegacias de Ensino, as escolas municipais e estaduais e APAE.

O coordenador do Projeto Jundiaí Cidade Saudável, Paulo Fernando Capucci, explicou que estes encontros visam aprofundar a visão dos políticos locais, em favor de uma cidade saudável.

Queremos discutir com os cabeças de chapa a construção de uma cidade melhor. Temos uma série de pontos e sugestões para fazer", contou Capucci. 
Cidades Saudáveis no Brasil e os processos participativos: os casos de Jundiaí e Maceió

Nestes encontros pretendemos apresentar o estágio de desenvolvimento do projeto aos candidatos e ouvir os planos que eles têm para favorecer um desenvolvimento saudável e sustentável para a nossa cidade e região", contou Paulo Fernando.

A agenda dos encontros já está confirmada, segundo Paulo: Pedro Bigardi participa amanhã, Miguel Haddad no dia 16, Walmor Barbosa Martins no dia 23 e Jorge Haddad no dia 30.

(...) Informa Sérgio Pio Bernardes, um dos coordenadores do Projeto, desde 94 estão sendo desenvolvidas várias atividades no município.

O coordenador dos concursos de Trabalho Ilustrativo, Slogan e Prêmios Para Professores, Sérgio Pio Bernardes, disse que o objetivo é atingir 85 mil estudantes.

A comissão se reúne no próximo mês para elaborar o cronograma e o regulamento do concurso estudantil", completou Capucci.

\section{DSC das organizações da sociedade civil}

Refiro-me, especificamente, ao convite que me foi feito pela Prefeitura Municipal através do Coordenador Municipal de Planejamento e da Secretária Municipal de Saúde, Marco Antonio e Ana Maria, respectivamente, para participar da apresentação do Projeto CS pelo Dr. Jack Lee e do Workshop a respeito, juntamente com um grupo seleto de pessoas, ocorrido nesta semana.

Marco Antonio e Ana Maria convidam Vanderlei Negro, presidente da ABECA (Associação dos Contabilistas) para o Workshop

Novamente ‘comprei’ a idéia... Vanderlei Negro ‘compra' a idéia.

Tenho muito gosto em participar, quer como representante da ABECA, quer como simples cidadão Jundiaiense, contribuindo para a melhoria da qualidade de vida geral.

O coordenador do GAC, Gerson Marques da Silva, salienta que é muito importante a participação dos moradores.

Gerson ressalta a importância da participação dos moradores.

Segundo ele a programação inclui a realização de trabalhos em grupo entre todos os participantes, de onde serão retirados questionamentos, que posteriormente serão discutidos em plenário.

Participantes realizarão trabalhos em grupo, questionarão e discutirão em plenário.

Ele explica ainda que as pessoas poderão expor as necessidades do bairro, os aspectos que podem ser melhorados, quais são as prioridades e depois discuti-las com representantes de cada área que estarão presentes.

O que vai ser proposto é a integração do bairro e de sua população, para que sejam tiradas diretrizes que serão repassadas à Prefeitura", diz Gerson Marques da Silva.

Os presidentes dos conselhos fizeram uma explanação sobre o trabalho realizado por cada um desses conselhos ao secretário de Planejamento, Sérgio Del Porto.

Nós pretendemos ir implantando o projeto bairro por bairro até conseguir unir toda a cidade", diz Maria Cristina Figueiredo, presidente do Instituto de Arquitetos do Brasil (IAB) núcleo Jundiaí.

Ele pressupõe duas coisas para funcionar: o planejamento e a participação de toda a sociedade civil de forma consciente e engajada. Sem isso ele não funciona", afirma o engenheiro César Augusto Traldi.

Serão 50 mil estudantes que participarão descrevendo como seria "Jundiaí - uma cidade saudável” ou fazendo um logotipo para o projeto", finaliza Traldi.

\section{4. $\quad$ DSC do Canadá}

Segundo Lee, o projeto prevê a criação de uma série de comissões para manter uma ligação direta entre técnicos e a população. 
Cidades Saudáveis no Brasil e os processos participativos: os casos de Jundiaí e Maceió

Lee destaca que questões relativas ao uso de drogas e segurança da mulher, estariam sendo resolvidas com rapidez nos países em que o projeto foi adotado.

As estratégias para o combate dos principais problemas sociais, de acordo com o canadense, pode demorar vários anos em alguns aspectos e, em outros, pode ser muito rápido. "Os projetos menores como segurança da mulher pode ter seus resultados constatados rapidamente. (Jack fala sobre as estratégias para o combate dos principais problemas sociais).

Para ele, a criação do projeto Cidade Saudável em Toronto foi muito importante. A participação da imprensa é o suporte fundamental para a divulgação do projeto", concluiu Lee se mostrou impressionado com o entusiasmo e interesse dos diversos segmentos da sociedade que participaram do evento.

Jack Lee, (...), elogiou o nível das discussões apresentadas pelas equipes, mostrando-se surpreso com a qualidade dos relatórios.

Jack Lee disse ainda que gostaria de manter-se informado sobre o andamento do projeto, colocando-se à disposição dos comitês para o esclarecimento de dúvidas e possíveis orientações.

$\mathrm{Na}$ verdade seremos quatro pessoas: um representante da federação canadense de municípios Brock Carlton, um professor da Universidade de Montreal, Mr. Latouz; Cláudia Marcondes da Universidade de Toronto e eu, que represento a prefeitura de Toronto.

Teremos a missão de analisar e verificar a adaptação dessas cidades ao projeto. A partir dessa análise, o governo canadense estudará a possibilidade de formar vínculos com o Brasil. Isto é, o governo canadense verá se vale a pena investir nassas cidades de forma efetiva.

Os canadenses prometeram continuar o relacionamento com Jundiaí, “para melhorar mutuamente”.

Estamos avaliando a possibilidade de Jundiaí obter ajuda do Canadá para a realização de projetos”, explica Brock Carlton, representante da Federação dos Municípios do Canadá.

Carlton descartou a liberação de dinheiro por parte do governo canadense. "Não haverá investimento financeiro, apenas troca de informações e auxílio técnico do governo do Canadá para a cidade de Jundiaí. 
Cidades Saudáveis no Brasil e os processos participativos: os casos de Jundiaí e Maceió

\section{ANEXO 4 - ROTEIRO DE ENTREVISTAS INDIVIDUAIS DE ACORDO COM OS GRUPOS PESQUISADOS}

\begin{tabular}{|c|c|}
\hline GRUPOS & QUESTÕES \\
\hline 1. gerentes & 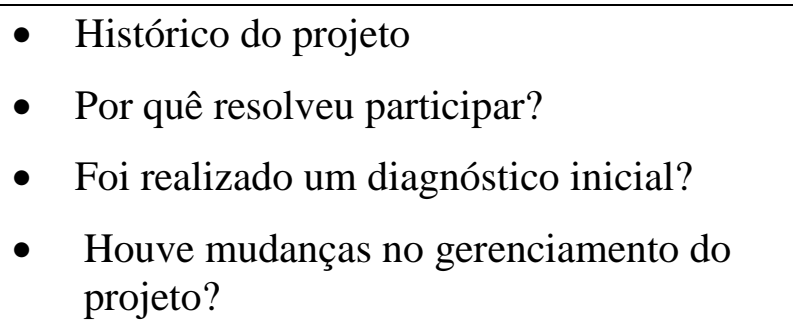 \\
\hline $\begin{array}{l}\text { 2. organizações/grupos da } \\
\text { sociedade que foram } \\
\text { convidados a participar do } \\
\text { projeto e aceitaram. }\end{array}$ & $\begin{array}{l}\text { - O que motivou a participação do grupo? } \\
\text { - Quais as atividades que foram } \\
\text { desenvolvidas? } \\
\text { - Como foram definidos os objetivos? } \\
\text { - Qual o impacto com relação aos objetivos } \\
\text { propostos? }\end{array}$ \\
\hline $\begin{array}{l}\text { 3. organizações/grupos da } \\
\text { sociedade que deixaram de } \\
\text { participar }\end{array}$ & $\begin{array}{l}\text { - O que motivou a participação do grupo? } \\
\text { - Por quê deixou de participar? }\end{array}$ \\
\hline $\begin{array}{l}\text { 4. } \quad \text { organizações/grupos da } \\
\text { sociedade que não participam }\end{array}$ & $\begin{array}{l}\text { - } \quad \text { Por quê o grupo não participar do projeto? } \\
\text { - O grupo tinha conhecimento do projeto? } \\
\text { - O grupo tentou se inserir no processo? } \\
\text { - Sentem-se excluídos do projeto? }\end{array}$ \\
\hline
\end{tabular}




\section{ANEXo 5 - GRUPO FOCAL - INSTRUÇões GERAIS E ROTEIRO}

A utilização de grupos como técnica de pesquisa é recomendada porque oferece uma maior possibilidade de se pensar coletivamente uma temática. Pressupõe que as opiniões e representações sejam socialmente construídas. É possível também conhecer como os processos de interação entre os participantes ocorrem, já que esses processos reproduzem o que ocorre fora dos grupos.

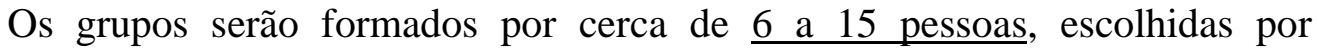
apresentarem um traço comum (amostra intencional), nesse caso os participantes fazem parte de grupos já constituídos que discutem e encaminham ações relativas ao Projeto Cidades Saudáveis, no caso de Jundiaí, e aos Projetos comunidades saudáveis, no caso de Maceió.

O grupo focal terá duração entre 60 e 90 minutos e será conduzido por um moderador, que vai propor uma série de questões aos participantes através de um Roteiro preparado a partir dos objetivos do estudo, sendo auxiliado por um observador.

\section{Papel do Moderador:}

- Explicar os objetivos da pesquisa e do grupo focal

- Encorajar os participantes a expressarem suas opiniões

- Manter a discussão focalizada

Papel do observador:

- Captar as informações não verbais

- Ajudar o moderador a analisar os possíveis vieses ocorridos

\section{Etapas:}

1. Apresentação dos objetivos de trabalho

2. Pedir consentimento para realizar a gravação

3. Garantia do anonimato

4. Garantia de devolução dos dados 


\section{ROTEIRO DE GRUPO FOCAL}

1. Como vocês participam na condução deste projeto?

2. Como o grupo elege seus representantes? Como se dá o retorno de informações?

3. Como é a comunicação e interação entre os participantes e suas respectivas bases sociais ou instituições que representam?

4. As pessoas que participam tem poder de decisão nas deliberações? A quem e como se consulta?

5. Como tem se dado a comunicação no projeto: entre os membros do grupo, entre governo e grupo, entre grupo e mídia?

6. Como tem se dado o envolvimento de terceiro setor ONG's?

7. Tem essa experiência contribuído para o fortalecimento e desenvolvimento da capacidade de participação dos diferentes setores? De que maneira?

8. Que impacto têm essas experiências de participação no alcance de metas de saúde? E com relação as metas de outros setores?

9. De que maneira essas experiências contribuem para assegurar mais e melhor a participação no futuro?

10. Essas experiências tem contribuído para melhorar a qualidade de vida da cidade?

11. Essas experiências têm contribuído para melhorar as políticas públicas?

12. Tem sido desenvolvidas formas de cooperação entre o governo local, os diversos grupos sociais?

13. Tem sido desenvolvidas formas de cooperação intersetoriais?

14. Tem sido desenvolvidas formas de cooperação gerenciais mais participativas?

15. Obstáculos que o grupo considera no desenvolvimento do projeto. 
Cidades Saudáveis no Brasil e os processos participativos: os casos de Jundiaí e Maceió

AneXo 6 - Parcerias Referidas nos Projetos Cidades SAUdáveis no Brasil

\begin{tabular}{|c|c|c|c|c|c|c|c|c|c|c|}
\hline & 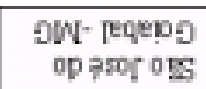 & $>$ & & $>$ & & & & $>$ & & \\
\hline & 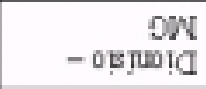 & $>$ & & $>$ & & & & $>$ & & \\
\hline & $\begin{array}{r}7 y \\
- \text { serposet }\end{array}$ & 7 & & & & & & 7 & & \\
\hline & 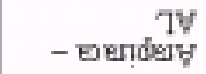 & 7 & 7 & 7 & & & & & & 7 \\
\hline & 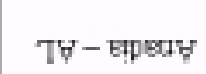 & $>$ & & $>$ & & & & $>$ & & \\
\hline & フV- 9 DOSN & $>$ & & $>$ & & & & $>$ & & \\
\hline & 3D-200150 & $>$ & & $>$ & & & & $>$ & & \\
\hline & $3 D-$ reqos & $>$ & $>$ & $>$ & $>$ & & & $>$ & & \\
\hline & 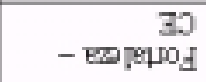 & & & & & & & & & \\
\hline 4 & oprempiow & 7 & 7 & 7 & & & & & & \\
\hline$\exists$ & $\mathrm{dd}$ - घparped & & & & & & & & & \\
\hline & $\begin{array}{r}\text { dd } \\
- \text { may naว }\end{array}$ & & & & & & & & & \\
\hline & dd-eqnung & $>$ & 7 & $>$ & & & & 7 & & 7 \\
\hline & $\forall q-$ renber & & & & & & & & & \\
\hline & $\begin{array}{c}\mathrm{dS}-\mathrm{yd} \\
\partial \text { w0I5E } \Lambda\end{array}$ & $>$ & & 7 & & & & 7 & & \\
\hline & $\mathrm{dS}$ - sovtres & & & & & & & & & \\
\hline & dS - pqutur & 7 & $>$ & $>$ & & $>$ & $>$ & $>$ & & \\
\hline & 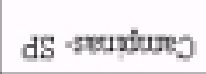 & $>$ & $>$ & $>$ & $>$ & $>$ & $>$ & $>$ & $>$ & \\
\hline & dS - euspe!d & & & & & & & $>$ & & \\
\hline & $\begin{array}{l}d S \\
-0 \text { plned og }\end{array}$ & $>$ & $>$ & 7 & 7 & & & & $>$ & 7 \\
\hline & 恣 & 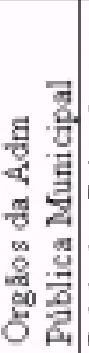 & 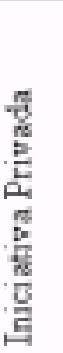 & 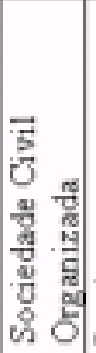 & 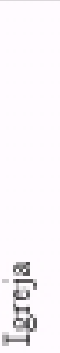 & 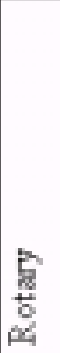 & 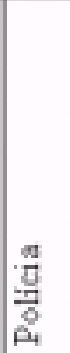 & 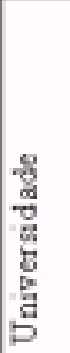 & 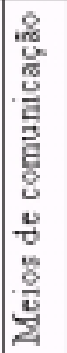 & 党 \\
\hline
\end{tabular}

